

$22^{50}$

Byx.y?3.

w. 

THE LIFE AND TIMES OF STEPHEN GIRARD MARINER AND MERCHANT 

Digitized by the Internet Archive in 2007 with funding from Microsoft Corporation 


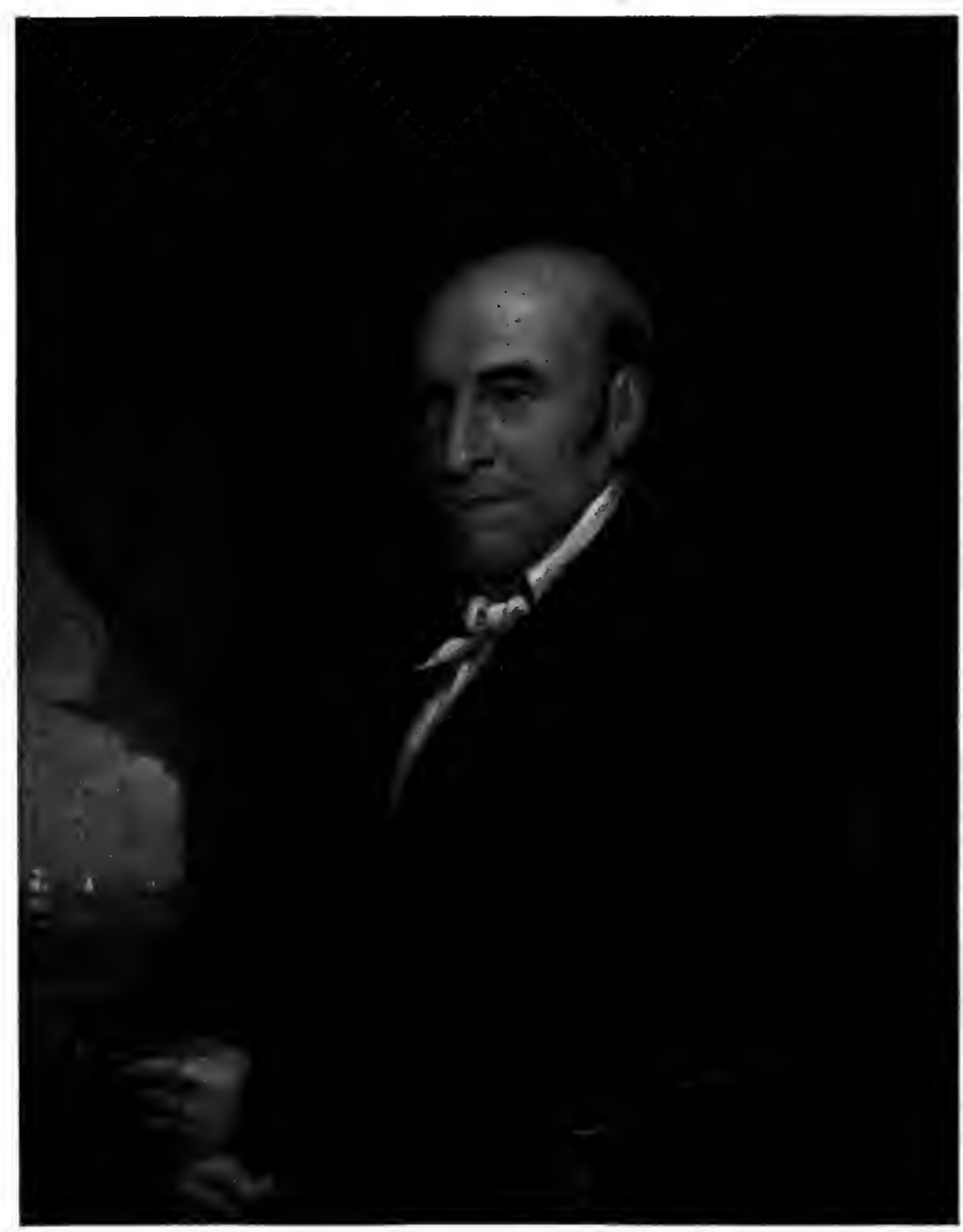

STEPHEN GIRARD

BY J. R. LAMBDIN

From a posthumous portrait by B. Otis in the Grand Lodge of Pennsylvania 


\title{
THE LIFE AND TIMES OF STEPHEN GIRARD MARINER AND MERCHANT
}

\author{
BY \\ JOHN BACH McMASTER \\ Professor of American History, University of Pennsylvania
}

WITH ILLUSTRATIONS IN COLOR AND DOUBLETONE

VOLUME I

PHILADELPHIA AND LONDON

J. B. LIPPINCOTT COMPANY

1918 


\section{CT \\ 275 \\ G.45M3 \\ $\mathrm{V} \cdot 1$}

COPYRIGHT, I9I 8, BY J. B. LIPPINCOTT COMPANY

PUBLISHED APRIL, 1918

PRINTED BY J. B. LIPPINCOTT COMPANY AT THE W ABHINGTON BQCARE PRESS

PEILA DELPGIA, U. S. A. 


\section{PREFACE}

Stephen Girard by will bequeathed to the Commonwealth of Pennsylvania $\$ 300,000$ and to the City of Philadelphia cash and real estate amounting in 1831 to over $\$ 6,000,000$. Never before had a private citizen of the United States bequeathed so vast a sum for the public good. By careful management the invested capital of the various trust funds created by his will now amounts to over $\$ 32,700,000$. Despite the great benefit the City has received from the income of these trust funds, and the community from the education of orphan boys in the College, no biography of Stephen Girard has hitherto been written, although he has been 86 years in his grave. A few sketches have been published, and a book by Stephen Simpson was issued immediately after the death of Girard in 1831 . The author was one time a cle:k in Girard's Bank, and, disappointed and disgruntled because he was not made cashier, avenged himself by writing a biography, false by deliberate intent and by lack of information.

Material for the story of the life of Girard as mariner, merchant and banker is abundant. The Girard manuscripts number more than 50,000 pieces. Of these, 14,000 are contained in his office letter books and represent his side of a voluminous correspondence. Some 36,000 are letters from his captains, supercargoes, agents, correspondents in every seaport of Europe from Petrograd to Trieste, in China, in the East Indies, in San Domingo and the West Indies, in South American ports, from correspondents in our own country and from bankers in Europe, Great Britain and at home. The remainder of the 
manuscript consists of ships' papers, documents relating to trials in prize courts, prices current, and papers treating of matters not connected with his mercantile and banking affairs.

The value of these papers is greatly enhanced by the extraordinary character of the times in which he lived. He came to our country just before the opening of the War for Independence, and during that war engaged in two privateering ventures which ended disastrously. After the peace he traded with French San Domingo until the massacre of the whites by the negroes and the establishment of the present negro Republic of Haiti put an end to all trade. Turning to Europe in 1793, just when France became a Republic and made war on Great Britain and brought on the world war of $1793-1815$, he suffered, as did other American merchants, from the plundering French Decrees and British Orders in Council. One after another his ships and his cargoes were seized by the French, by the British, by the Swedes and the Danes.

During this period Girard appears as a bold and adventurous trader taking great risks, suffering heavy losses, reaping rich profits. But the letters from his correspondents do much more than report the success or failure of his mercantile adventures. They are full of detail of political and military events abroad and of the effects of these conditions on the markets of the world. In the course of his long career as a merchant-trader Girard was the owner of eighteen vessels. Sixteen belong to the years before 1812; but at no one time did his fleet consist of more than six ships. Many more were chartered and, like his own, sent to European ports. Rarely, therefore, did any event of great political or commercial importance happen abroad but Girard had a captain, a 
supercargo, agent or consignee on the spot to send him first-hand information. In his correspondence are descriptions of the burning of Cap Français and the massacre and flight of the French from San Domingo; of the experiences of his captains when their vessels were taken by the French, or brought before a British vice admiralty court, or searched at sea by a British cruiser, or captured by the Danes and tried in a Danish admiralty court; of the treatment of American claimants under the Louisiana Purchase treaty, the working of Napoleon's Continental System, the effects of his victories and defeats. When General Matthews seized East Florida in the name of the United States; when Jackson fought the battle of New Orleans, there was some one on the spot to describe what occurred; and so it was when Napoleon was beaten at Leipsic, when he returned from Elba, and when he abdicated after Waterloo; when Belgium rebelled against the King of the Netherlands, and when the French drove out Charles $\mathrm{X}$ and put the Duke of Orléans on the throne. Girard's relations with Joseph Bonaparte and the French refugees throw some light on their efforts to plant colonies in Alabama and Texas.

Girard, when our war with Great Britain opened in 1812, was possessed of far more wealth than, with safety, he could use in his commercial ventures. He turned, therefore, to banking, became the first private banker in our country, and rose rapidly to importance in national finance. His letters at this period reveal the troubles which beset him from the hostility of the Philadelphia banks and the Legislature of Pennsylvania; and show how, with David Parish, by his great subscription he enabled the Government to float a loan of $\$ 16, \infty 00,000$ for which the people of the entire country had not subscribed fifty per cent. When the second Bank of the United States 


\section{PREFACE}

was chartered and the stock did not sell it was his subscription of $\$ 3,000,000$ that made it possible for the directors to complete the organization of the Bank and begin business.

Free use of all this correspondence has been made in this biography. So complete and almost unbroken are the letter files that it has been possible by joining letter to answer to make Girard and his correspondents tell the story of his career from cabin boy on a French merchantman trading with San Domingo, to that of the merchant prince, greatest private banker, and greatest public benefactor of his time.

John Bach McMaster

April, 1918 


\section{CONTENTS}

\section{VOLUME I}

CHAPTER

I. Trading and Privateering $\ldots \ldots \ldots \ldots \ldots \ldots \ldots \ldots \ldots \ldots$ I

II. The Two Brothers $\ldots \ldots \ldots \ldots \ldots \ldots \ldots \ldots \ldots \ldots \ldots \ldots, 49$

III. A Speculation in Wheat....................... 94

IV. San Domingo and Marseilles ................. 122

V. La Virginie Sold. Good Friends Embargoed.......... 167

VI. Captures of the Kitty and the Sally............ 212

VII. The Liberty, Voltaire and Sally Built. . . . . . . . . 274

VIII. The Liberty Captured; the Modest Wrecked......... 323

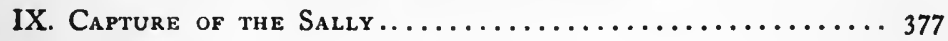

X. Trading with France and Russia $\ldots \ldots \ldots \ldots \ldots \ldots \ldots \ldots . \ldots \ldots$

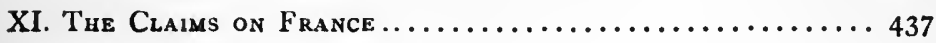




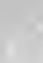

1
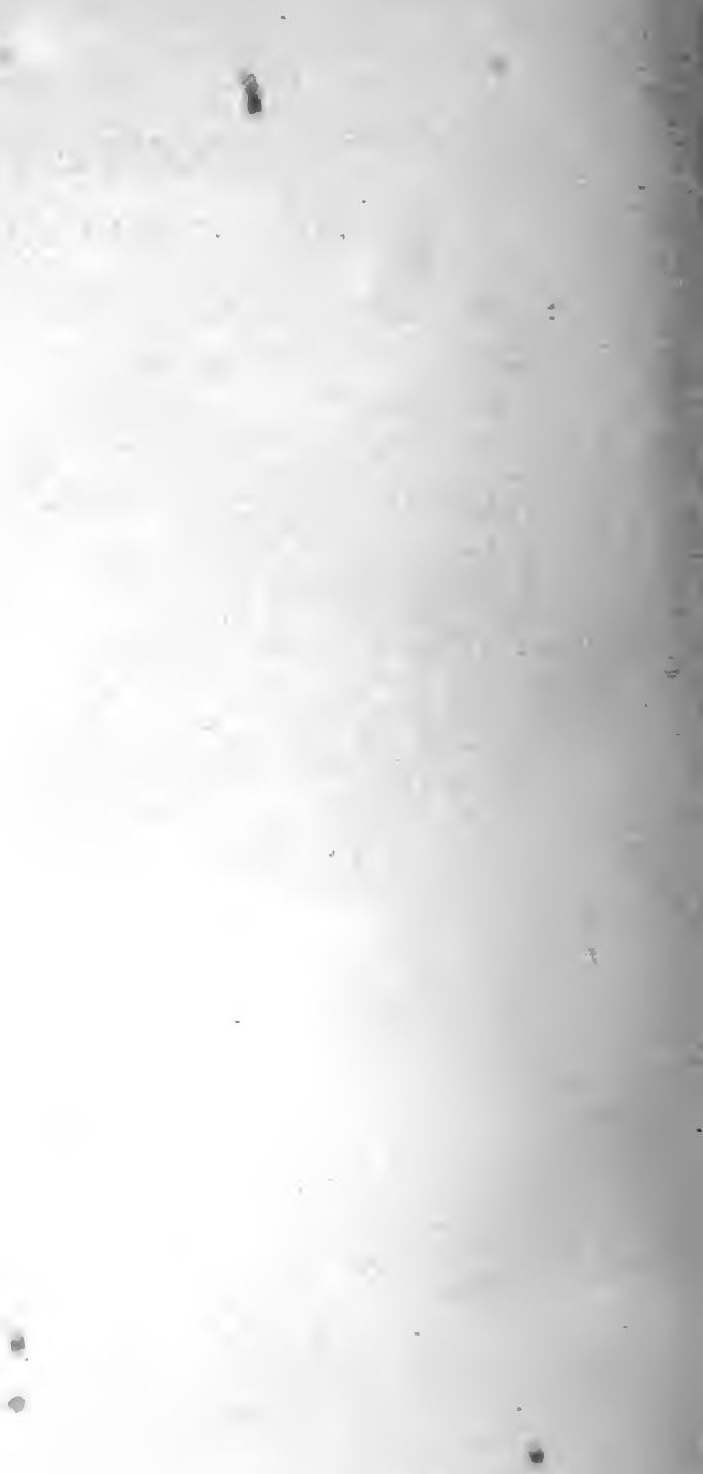


\section{ILLUSTRATIONS}

VOLUME I

PAGE

Stephen Girard........................ Frontispiece

23 North Water Street. . . . . . . . . . . . . . . 279

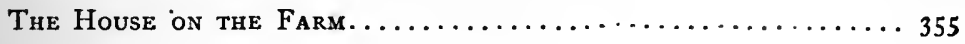





\section{THE LIFE AND TIMES OF STEPHEN GIRARD}

MARINER AND MERCHANT

\section{VOLUME I}

\section{CHAPTER I \\ TRADING AND PRIVATEERING}

On the fifteenth of February, I748, so runs the record at Bordeaux, after celebration of the betrothal and publication of one ban, my lord, the archbishop, having granted a dispensation suspending publication of the other two, no opposition having been made and no impediment having been discovered, the vicar of St. Seurin united in marriage, and gave the wedding benediction to, Pierre Girard, Port Captain, and Odette Lafargue, habitante of the parish of St. Remy, all of which was duly witnessed and the certificate signed by the sexton, the bell ringer and the clerk of the vestry room.

From this marriage in the course of fourteen years came ten children, of whom the second child and eldest son was named Etienne in honor of his godfather, Etienne Souisse, a burgess of Bordeaux. Etienne, or Stephen, was born on the twentieth of May, 1750, and baptized the next day in St. Seurin, one of the three churches in Bordeaux in which baptism was permitted. Concerning his early life nothing, or next to nothing, is known.

He was born, so far as he knew, in a house in Rue Ramonet au Chartrons, then a suburb of Bordeaux, but now well within the business center. The street, some thirty feet wide and four hundred long, runs at right angles to the Quay des Chartrons, a wide avenue along 
the river front, and is entered through a narrow archway twelve feet wide. But all recollections of Pierre Girard and his children, and of Ann Lafargue, the aunt, who lived for many years in the old house, have disappeared. The house, it may be, was pulled down to make room for a warehouse which faces the quay.

That he was probably born blind in his right eye, for he could not remember ever having the use of it; that his education was scanty; that he paid for a part of it with his own earnings made at sea; that when twelve years old the death of his mother left him a half orphan, and that at fourteen he began his seafaring life, is about all that is definitely known concerning his boyhood days.

In 1767 Pierre Girard married a second time and by this wife, according to the record of baptisms in St. Seurin, had four children. Of his many brothers and sisters but six in any way entered into his life. Madelaine, a nun, Victoire, Sophie, Jean, Etienne, named after him, and his half sister Catherine, and no others, appear in his correspondence, and, save Jean and the nun, are associated with him chiefly as dependents on his bounty.

From such fragmentary records as have come down to us it appears that Pierre Girard in his day was a man of force, a merchant of some little importance and a citizen of distinction. It was the custom in those days to require would-be shipmasters to serve two years in the French navy before receiving their licenses to command merchant ships. In 1744, while Pierre Girard was serving his time, the war of the Austrian Succession opened, the British blockaded the port of Brest, and sent a fire ship into the midst of the French squadron. The vessel on which was Pierre Girard was soon in flames; but he put them out at the risk of his life and saved her. Hearing of this act, His Majesty, Louis XV, conferred on Girard the Royal 
and Military Order of Saint Louis, and commanded that his name be enrolled in the Register of the Admiralty at Paris.

An office much sought by the habitants of Bordeaux was that of Burgess. From the municipal records of that city it appears that in February, 1767 , "M. Pierre Girard, merchant, naval officer, pensioner of his Majesty, decorated with the medal, habitant of the City, has taken the oath of Burgess, in the accustomed manner, after due inquiry as to his good life and good morals."

As a merchant Pierre Girard traded with the ports in the French part of the island of San Domingo. It was to Port-au-Prince, therefore, that Stephen went in 1764 , on his first voyage as cabin boy in a vessel in which his father had taken a venture. After five more voyages he was made "officer," or lieutenant, and in 1773 was licensed to act as captain, master, or pilot of any merchant ship he could obtain. The law of the kingdom required that seekers of such licenses should be twenty-five years old, and should have served two years in vessels of the Royal $\mathrm{Navy}$ before they could be examined as to their knowledge of seamanship and fitness to command. For reasons of some sort these requirements were waived in the case of young Girard and the license was granted. Nevertheless it was as "officer of the ship" that he sailed on La Julie from Bordeaux for Port-au-Prince in $\mathbf{1 7 7 4}$.

On this voyage he had a small share in the cargo, a share worth a few thousand livres, and consisting of bales of handkerchiefs, boxes of hats, saddle blankets, and articles suitable to the market purchased from merchants of Bordeaux with notes of hand. While these were being disposed of at St. Marc, his duty at Cap Français was to make collections for the owners of the rest of the cargo of La Julie, that the return cargo might be secured with the 
utmost speed. Instructions bade him follow up the debtors closely, be very careful of expenses, put his collections in safe hands lest he be robbed, send each week to St. Marc a statement of the collections made, and in going about "watch, without appearing to do so, the boats lying at anchor which will probably touch at St. Marc, find out when they will each leave, and all about those which will sail direct to France," and be ready to go back in La Julie when she sailed from St. Marc.

But Girard was never to return to his native city. His merchandise sold at a loss of 25 per cent. He was unable to pay the merchants from whom he bought the goods, and fearing imprisonment for debt, should he go back to Bordeaux, he sought a discharge from the roll of the ship. A friend at St. Marc who was endeavoring to sell some goods belonging to him undertook to "sound the Captain," and finding that officer kindly disposed, Girard wrote and obtained his discharge on condition that he watch over the interests of the owners of the cargo of La Julie at Port-au-Prince, and collect debts due them till the ship sailed.

This done the discharge was sent in June, 1774. While waiting for the document Girard sought to form a partnership with a young acquaintance, buy a small brig and trade from port to port of the island. The capital of his friend was but three thousand livres, was apparently too small, and in July, $\mathbf{1 7 7 4}$, Girard sailed for New York, taking with him sugar and coffee purchased with the proceeds of the sale of his Bordeaux goods.

At New York he probably sought employment by some merchant who traded with San Domingo. Be this as it may, he found such employment by Thomas Randall \& Son and as mate of a snow sailed for Le Cap. Other voyages followed, he became a captain and though the 
privileges allowed a captain were small, such good use was made of them that his little capital was steadily growing when the fights at Concord and Lexington opened the war between the mother country and her colonies.

To the father the conduct of the son in avoiding his creditors, and the war risks of the trade in which he was engaged were sources of great regret and anxiety and brought from the elder Girard a letter to which Stephen replied from Cap Français:

"I received with a lively joy several of your letters, the last dated May 22, 1775, which I cannot read without shedding torrents of tears at the thought of your love for me. Letters like yours are fountains of intelligence, virtue and probity to a dutiful son. As to remembering the religion in which I was born, as you bid me do, I shall never forget it any more than I shall forget the pains you took to bring me up according to its precepts.

"Your remonstrances in regard to the commerce I am engaged in here have troubled me very much and have had the greatest possible effect on me. I hope providence will save me from such a scourge. In your last you say that it is perhaps the last letter you will ever write to me. Is it your intention, my father, to deprive me of the only comfort I have left in case of trouble, anxiety and fatigue? I appeal to your fatherly love to support me with your counsels, and assist me to overcome the difficulties I am experiencing in this hazardous traffic.

"The distance between us has not made me forget my creditors, but as the voyage I have just made to the Mississippi has not been lucrative, and I was obliged to leave some of my funds there, I cannot send any money till I come back from the aforesaid place, which will be in seven months from now, when I expect to send you a remittance of 15,000 livres by way of either Le Cap or Port-au-Prince. 
Uńless I succeed in realizing the sum of 15,000 livres I shall never summon the necessary resolution to pass through Bordeaux. At the present time I have from thirty to thirty-five thousand livres, money of the Colonies, and with the help of God I hope soon to be in a position to realize my desires."

The voyage to New Orleans mentioned in the letter was his last to that port. News of the opening of the war between Great Britain and her colonies reached him there, and fearing for the safety of his vessel, he made a fictitious sale of it to a French merchant, "a formality made necessary," says the document acknowledging the pretended sale, "to avoid the risk which he fears by meeting some vessel of the King of England." By the middle of April, I776, Girard was at Cap Français and a month later sailed from St. Pierre, Miquelon, as master and half owner of the bateau La Jeune Babé. High winds and seas beset her from the start, and on the second day out, according to the log, a great wave "threw off two hogsheads of fresh water stowed to leeward." On the seventh day, "the sea frightful," says the log, several great waves broke over the ship, the third of which unwedged the masts, cracked the jury mast and swept overboard a third hogshead of fresh water stowed to starboard. His situation was now serious and the next afternoon the crew came aft and spoke to him concerning the small quantity and bad quality of the water, of which but a part of one hogshead remained. As this would not be sufficient for the remainder of the voyage, Girard determined to put into Philadelphia, "believing that on these coasts I should meet with some vessels of the King of England which would supply me with water or grant me protection on entering some port, in short to be under shelter from dangers incident to this country which they say has rebelled against its prince." 
A week now passed without adventure, but on the morning of the twenty-ninth of May, a three masted vessel was sighted and recognized as a frigate towards which he steered, hoping to get water; but "it crowded on all sail to run after two vessels which were to the leeward of us," and was soon out of sight. "At daybreak on the 3oth I sighted an English vessel which I signaled to speak. At 5 o'clock in the morning it perceived me and reached me at $60^{\prime}$ 'clock. It came along side me and proved to be an English frigate. It was coasting between Philadelphia and the Carolinas to seize any boat which had on board any powder as freight. I asked for water and the captain said in reply that he was going to send some by his long boat, which long boat came alongside with a lieutenant who did not bring any water, and made me embark with my papers in his long boat to go on board to his captain who appeared to me to be a very gallant man. He examined my papers and kept on board an Irish sailor who had gone with me. In doing so, he did me a great injury, as he was the best cook that I had on board my vessel." The remainder of the log is lost, but La Jeune Babé came safely to Philadelphia, the city destined to become her captain's future home.

The little city on the bank of the Delaware to which the fortunes of a sailor's life thus brought Girard one June day, 1776 , was first in population, and first in trade and commerce, among the cities of the thirteen colonies. Could we go back across near a century and a half and see Philadelphia as he first saw it we should scarcely recognize the place. The population would dwindle to 24,000 . The area would shrink to the narrow confines of the Delaware and the Schuylkill Rivers, Vine Street on the North and Cedar, or as we know it, South Street on the south, and regions now crossed by miles of streets, and covered by thousands 
of dwellings would appear as farms, cow pastures or waste land. Had a line been drawn around the well populated part of the city, it would have started at the Delaware River at the foot of Vine Street, gone thence to Fourth and Race; thence to Market and Seventh, and then to South and Front. West of this line houses were indeed to be found but they were few and far apart. South East Square, or, as we know it, Washington Square, was in the open country and still used as the Potter's field. There were no dwellings near St. Peter's Church. The State House Yard was little better than a fenced-in lot, for no attempt to improve it was made till 1785 . Chestnut and Market Streets east of Sixth were still residence streets. Indeed, in the section south of Market were some of the finest dwellings in the city, many of them surrounded by gardens shut from the street by high brick walls. But nowhere was there to be seen a bank, an office building, a free public school house maintained at the expense of the city, or a great hotel. The London Coffee House was the center of commercial life. To it each week day came the merchants, traders, business men, to exchange gossip and discuss the affairs of the day. There was kept the book in which captains, just home from foreign ports, entered such maritime news as they thought of interest. There, on file, were the newspapers from Boston, New York, Baltimore and Charleston, and such foreign journals as the captains or supercargoes brought home. There were posted notices of ships to charter, or of freight wanted. There political meetings were held, there arbitrators settled matters in dispute between merchants, and there dinners were given on great occasions.

The life of the city as Girard saw it on the streets still bore the character of Colonial days. The post rider, the lumbering stage wagon, the chimney sweep with his num- 
ber on his cap, the bellman, the porters with their loads on their backs, the drayman with his longtailed dray, the slave, the redemptioner, the apprentice boy, the constable wandering about his ward during the day, the watchmen with their lanterns patrolling the streets at night, the poor debtors letting down their caps, by strings, from the windows of the prison in hopes that some charitable passer-by would drop into them a few pence, the women drawing water from the pumps along the streets, were figures familiar enough to Girard but unknown to us.

The fire in the kitchen and on the hearth was still lighted by sparks struck from a flint and steel, or by embers borrowed from a neighbour. The dipped candle, the candle mould, the whale oil lamp of pewter or glass were still found in almost every household.

Communication was slow, uncertain and laborious. The merchant who wrote to a correspondent in Europe always made three and often six copies of his letter and sent each by the captain or supercargo of a different ship. Once a month the London Packet left New York carrying passengers and mail on which a heavy postage was charged. Were the weather fair and the winds favorable, London might be reached in twenty-two days. A voyage to Marseilles took from five to seven weeks; to Amsterdam sometimes as many as five weeks. Months might elapse before a reply was received, for an opportunity did not offer every day and a ship when ready to sail might be long wind bound in port.

Foreign correspondents filled their letters not only with reports of sales of the cargoes entrusted to their care, prices current and state of the market, but with political news.

For most of such news the merchant was dependent on the newspapers published in his city. When Girard 


\section{THE LIFE AND TIMES OF STEPHEN GIRARD}

came to Philadelphia the city boasted of five, the Gazette, Journal, Ledger, Evening Post and the Packet. Each was a small four-page sheet given up to advertisements of ships to sail and goods to sell, offers of reward for the capture of runaway slaves or indentured servants, notices of the arrival of German Redemptioners, and long extracts from the debates in Parliament copied from the London newspapers.

These debates were read with interest, for the times were critical. The Colonies and the mother country had come to blows; Concord and Lexington had been fought; Howe had been forced to evacuate Boston, and the Continental Congress, sitting in the State House, had just recommended the Colonies to form independent governments. The city was seething with political excitement.

In all this, however, Girard had neither part nor lot. As a Frenchman trading with the West Indies he was not concerned in the rebellion of the British colonies. Ships, commerce, the accumulation of a fortune alone occupied his thoughts. Nevertheless his arrival, though he knew it not, marked an epoch in his life, for, from that day till his death fifty-five years later, Philadelphia was his home.

No record shows what became of the ship and cargo. As Girard was not a man to remain idle it is quite likely that he made another voyage to St. Domingo, but if so no record remains. When, however, the British, in July, attacked New York, Thomas Randall came to Philadelphia and on joint account with Girard and Isaac Hazlehurst continued to trade with St. Domingo, sending out produce and bringing back articles manufactured in France. In these ventures the names of three vessels, the Sally, the Betsy, and the Lucretia, appear.

A letter of instructions to Girard written in Philadelphia by Randall, in August, 1776, reads, 
"The sloop Sally whereof you are now master being complete for sea, it is our desire that you proceed to the Cape with all possible expedition and when arrived you are to dispose of your cargo to the very best advantage leaving no debts or accounts unsettled."

In September Girard was at Le Cap; in October he was back in Philadelphia, and, as appears by a letter from Mr. Randall, then at "Elizabeth Town," was proposing to return to St. Domingo.

"I received yours by the post and was very glad to find by it that you are safe arrived in health. My sons are both gone to Boston. The rest of my famerly have been indisposed, but are now parfitely Recov'd; they all Joyne me in our best Respects to you. as to the Destanation of your Voyage, I must leave it entirely to you. I shold be happy to see you before you go out again. We are all in Confusion hear, as I have bought a plantation about twelve miles back in the Country, and am now about moving my famerly thair. as I have not the particulars of your Cargo of Drygoods I cannot tel what I may want for famerly Use, but I have order'd Mr. Hazlehurst not sell them yet til I can here from the Gent Concerned."

In a postscript he adds,

"If you write to me in English I shall be glad, as my Daughter is a very bad translater."

No time was lost in unloading and loading the Sally and on October 26, from "Elizabeth Town," Mr. Randall wrote, "Your esteemed favor of the 2oth came duly to hand, by which we find that you are now departing. Your a/c shall be regularly stated \& the balance paid to Mr. $\mathrm{H}$. agreeable to your order. Shall be much obliged to you to procure for me the following articles for my own use."

Business relations between the two men seem to have ended in February, 1777, when all accounts were balanced 
and $£_{1524} 6 s$ paid him. The balance sheet shows that Girard was part owner of two vessels, the sloop Betsy and the brig Lucretia, that his share in the outward and inward cargoes was at one time $I / 3$, at another $2 / 3$, at another $1 / 2$; that in August, 1776 , the Lucretia was " taken in public use," and that the last voyage of the Betsy was to Port-au-Prince, from which she returned in January, I777, leaving behind her unsold goods in the hands of Tardieu \& Co. worth 4784 livres, money of the colony, for which no remittance was received till the spring of I780.

The presence of British cruisers off the coast, and the impossibility of getting insurance, forced Girard to abandon the sea and settle down to buying and selling wholesale, such commodities as found a ready sale in the city and country round about.

While so engaged he met, and on June 6th, 1777, married Mary Lum, and took up his residence at the house of Walter Shay. Having a wife he needs must have a home, and on July 22, 1777, he bought from Isaac Hazlehurst a story and a half house and a few acres of land at Mount Holly, New Jersey, paying for it $£_{528}$ igs Pennsylvania currency.

When the war for independence opened the money of account of the Colonies was pounds, shillings and pence. The money of exchange was coins of foreign mintage and paper "bills of credit" put out by the Colonies since 1689. To these issues, as the war progressed, the Continental Congress added a flood of Continental bills of credit. The value of the paper money of the Colonies and the States was generally expressed in pounds, shillings and pence. But the Continental Congress adopted the Spanish milled dollar as its money of account, and from the very first the values of all its paper money and obligations, and the 
amounts of all the appropriations it ever made and all the quotas of money it ever called for from the States were expressed in Spanish milled dollars and ninetieths.

This silver coin, "piece of eight," was valued in 1704 at 4 shillings 6 pence sterling; but in course of time the Colonies so changed this rating that, in 1777, in New Hampshire, Massachusetts, Rhode Island and Connecticut and Virginia 6 shillings; in New York and North Carolina 8 shillings; in New Jersey, Pennsylvania, Delaware and Maryland 7 shillings 6 pence; in South Carolina 32 shillings 6 pence and in Georgia 5 shillings made a Spanish milled dollar. A pound New England and Virginia currency, therefore, was worth 3.33 I /3 Spanish milled dollars; a pound New York and North Carolina money, two dollars and a half, and a pound currency of Pennsylvania and her neighbors $2.662 / 3$ dollars. In Pennsylvania, however, where the dollar was rated at 7 shillings 6 pence, it was considered to contain 90 pence and all fractions were so expressed; as, $\$$ I $4.75 / 90$.

Besides the "piece of eight" the coins in general use were English and French guineas, the Joe or Johannes and its half, quarter, eighth and sixteenth, the Spanish pistole, French pistole, the Moidore, the Doubloon, the English and French crowns, the shilling and the six pence, the current values of all of which were settled by state tariffs.

For many years the trade carried on by Girard was chiefly with France, Cap Français and Port-au-Prince, St. Domingo. In his letters, invoices, bills of lading, accounts and prices current, the livre tournois, piastre gourde, and piastre forte, therefore, occur incessantly. The livre tournois, or livre of Tours, was divided into 20 sous and each sou into 12 deniers, and had different values at different times both during and after the revo- 
lution; but in Pennsylvania, where there were ninety parts to the dollar, the livre was commonly rated at $162 / 3$ pence and 5 livres 8 sous made a dollar. The piastre gourde was worth one dollar, and the piastre forte the same. An ordinance of the Pennsylvania Convention, January 29, I777, made £I 55 Pennsylvania currency the equivalent of £ıoO sterling; made eight Continental paper dollars, or three pounds Pennsylvania currency, the equivalent of one gold half Johannes of full weight, and $756 d$ the equivalent of one dollar Continental money or a Spanish milled silver dollar, and declared both Continental bills and Pennsylvania bills legal tender. As a pound Pennsylvania money was worth 2.66 Spanish milled dollars or Continental paper dollars, the price paid for the Mount Holly property, $£_{528}$ igs Pennsylvania money, was 1407 dollars.

During the British occupation of Philadelphia, Girard built or purchased his first vessel, probably the Water Witch, which he is said to have owned but which does not appear anywhere in his correspondence. When, however, the British left the city in June, $\mathbf{1 7 7 8}$, she was seized and carried off by them and never again seen by her owner.

No sooner, however, was Philadelphia once more in American hands and the channels of foreign trade open, than Girard returned to the city, rented a house and store, in North Water Street, for "eighty pounds hard money" a year, and prepared to buy and sell wholesale. To do this he must take the oath of allegiance required by an Act passed by the Assembly of Pennsylvania, June I $3^{\text {th }}$, 1777. Sundry persons, the act set forth, moved by sordid and mercenary motives and other causes inconsistent with the happiness of a free and independent people, had been induced to withhold their services and allegiance 
from the Commonwealth of Pennsylvania. Sundry other persons at the risk of their lives and the hazard of their fortunes had rendered great and eminent services in defence of her independence. As both sorts were mixed and undistinguished from each other the disaffected derived undeserved service from the faithful, therefore, that they might be separated and become known, all male white inhabitants above the age of eighteen must, on or before the first day of July, 1777, take and subscribe an oath of allegiance before some justice of the peace. All who did so renounced allegiance to George Third, King of Great Britain, swore to bear true and faithful allegiance to the Commonwealth of Pennsylvania, never do anything prejudicial to the freedom and independence thereof, and discover and make known to some justice of the peace all treasons or traitorous conspiracies whereof they were cognizant. Such as did not take the oath were declared incapable of holding any office of trust, serving as jurors, electing or being elected, or of buying, selling or transferring any lands or tenements. Anyone travelling out of the city or county where he resided without a certificate showing that he had taken the oath was to be suspected of being a spy and of holding principles inimical to the United States, was to be seized, taken before the nearest justice of the peace, tendered the oath, and on refusing to take it, sent to jail, there to stay till he became loyal.

Four classes were exempt,- - delegates to the Continental Congress then sitting in Philadelphia, officers and soldiers of the Continental army, prisoners of war, and merchants and mariners of friendly powers, trading in the ports of the Commonwealth and not becoming resident. April I, 1778, a new "Act for the Further Security of Government" required all who had not hitherto 
taken the oath of allegiance to do so on or before the first of June, 1778 , or suffer all the penalties of the Act of June 13,1777 , and in addition be rendered incapable of suing at law, of acting as administrator or guardian, of receiving any gift or legacy, of making a will or testament, and be forced to pay double the taxes which, on the same property, would be required of one who had sworn allegiance to the Commonwealth.

When Girard moved to Philadelphia he fell under this law, and in October, 1778 , took the required oath. But the Assembly on the fifth of December, 1778, enacted yet another law which provided that every person who had taken and subscribed the oath since the first

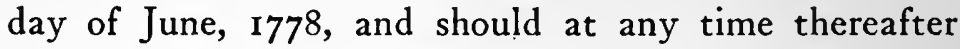
take and subscribe another form of oath recited in the act, should thereby become "a free citizen of the State and be entitled to" all the rights and privileges of free citizens. Having taken the old form of oath since June I, I778, Girard took and subscribed the new form on August second, I779, and so became a free citizen of Pennsylvania.

To get business, he wrote to his father, to his brother, and to old friends at Cap Français and Port-au-Prince stating the opportunities for trade, the large profits to be made and asking for consignments. To his father he wrote, "owing to the dangers of the sea, there being no possibility of insuring here, I shall be forced to stay here at least until the end of the war, and meanwhile intend to do some business in this country. I therefore appeal to your fatherly love and friendship to procure from your friends as much commission and other business as you can, and in case you should wish to fit out a vessel or take an interest in some vessel bound for Philadelphia, I enclose a list of commodities suitable for this country both for Spring and Fall. If you should engage 
in such a venture and cover the entire outlay with a good and reliable insurance with a credit for one year, I should be delighted to take a one-tenth interest in the cargo. Take care to select a vessel that does not draw more than thirteen feet of water and is a fairly fast sailer; you cannot be too careful in choosing the crew. Arm the vessel with a few cannon, at least enough to enable her to defend herself against any gun-boat that might attack her on the voyage across, or on our coasta thing of daily occurrence-and give the command to some trustworthy man from your own river, by preference to one who is known as a good sailor. It is impossible to loose on such a venture. I believe that, barring accidents, there ought to be a big profit in view of the high prices of every kind of merchandise in this market.

"I should be humbly obliged if you would renew your acquaintance with old friends at Marseilles, Bayonne, Rochelle, as well as in Brittany and Normundy and refer them to me at Philadelphia. And do not forget your friend M. Mosnier at Amsterdam. I venture to predict that they will be delighted with the correspondent you are getting for them, as I am determined to work with all the intelligence and honesty with which you have inspired me. I am writing to my brother at Le Cap with whom I ardently wish to form a partnership. I believe that if he came here we could between us, do a great deal of business, as one of us could look after the store while the other was away on a voyage."

The brother was Jean Girard, who, shortly before this time, had established himself as a commission merchant and trader at Le Cap. "Get," said Girard to him, "if you can, a solid insurance in France, buy a bark or schooner at Le Cap, load her with salt or syrup, select

Vol. I-2 
a good sailor and honest fellow for captain and come with the vessel to Philadelphia, where you will make a big profit on your cargo after deducting the insurance premium. Syrup is now worth four gourdes a gallon and salt twenty-four a bushel. When you arrive here, we might form a partnership to carry on the business in which I am engaged, which consists of buying and selling, while we wait for other business from Europe or the Islands. If you come, bring no negroes, and take nothing but your clothes, so as to pass for a passenger on the ship's register. Then, in case you are overhauled, you run no risk of being taken prisoner."

To his old friend Tardieu, merchant at Le Cap, he announced his determination to remain in Philadelphia and offered his best services. "Should you have a vessel to dispatch to this country and feel sufficient confidence in me to give me the consignment, I venture to say that I am in a position to dispatch the same as promptly as anyone here." Nau \& Co., with whom in days past he had done business at Port-au-Prince, were informed that, "disgusted with the risks of sea-voyages and the dangers of the enemy," he had decided to stay in Philadelphia, and go into business. Should they or any of their friends send a consignment to, or have any other business in the City, he hoped they would not forget him. Great profit could be made by fitting out a vessel for Philadelphia, and loading her with syrup, salt from Turks Island, sugar and coffee. Syrup was worth thirtythree livres a gallon, salt one hundred and eighty a bushel, and sugar from seven to eight livres a hundredweight.

During three years and more Girard had not heard from his father; but one day in January, 1779, happening to meet Mr. Randall, he received a letter some four 
months old, written by a stranger in Yorktown and enclosing a copy of a letter of introduction from Pierre Girard, sent in care of Mr. Randall, "who was so obliging as to forget the letter and accordingly delivered it four months after its date." "I have," the father wrote at the foot of the note of introduction, "been omitted from your letters. Your brother has told me that you have made a personal change of which you have not informed me, but of which I desire to know all the circumstances as soon as possible, and also what business you will have when the English have evacuated Philadelphia."

"You ask," said the son in reply, "for information in regard to the circumstances attending the personal affair that I have been recently concerned in here. The silence I have observed in regard to it up to the present time you must attribute to the natural bashfulness of a son, who, though far from his father, fears to incur his displeasure; but since it is your wish, I will tell you about it in detail. Tired of the risks of a sailor's life and accompanying libertinage without religious control, I determined to settle ashore in order to keep what was left of the fruits of several years toil. As I could hardly do this without marrying, I have taken a wife who is without fortune, it is true, but whom I love and with whom I am living very happily. As regards my business, the English seized a new brig belonging to me that was in the river. When they left, all I possessed was a small estate in the country valued at ten thousand livres, in specie, and about fifteen thousand in paper money of St. Domingo. But, by hard work, I have since ther finished furnishing my house, bought a small negro, increased my capital to thirty-five thousand and hope soon to make good my past losses. 
"I have moved and am keeping store in Water Street, where I buy and sell wholesale in order to be able to stand the heavy expense I am now under on account of the high price of every kind of provisions in this place. I hope you will take my situation to heart and tell your friends about me, offering them my services.

"There is some prospect of the English evacuating New York, in which case the position of French Consul would become vacant. It is an honorable and very lucrative post and I humbly beg you to use your influence with your friends to get it for me. If, however, you should experience difficulty because of my being so far from you, send me if possible a letter of introduction to M. De Gerrard, ambassador to this country from the Court of France, for the purpose of informing him who I am. I should be very glad to establish myself in New York where all my old acquaintances live.

"I have not forgotten the debt I contracted at Bordeaux, and intend to do all I can, even stint myself if necessary, to make good my engagements as soon as the risks of the sea are a little less dangerous."

To his suggestion that Jean Girard should come to Philadelphia and form a partnership, the brother now replied by requesting him to collect some money due him "on the shore of Casco Bay, Boston and elsewhere," and with it buy a good farm twenty or thirty miles from Philadelphia, "my intention being to go there after the war." He was sure heavy taxes would force many poor people to sell and settle on new lands further away.

Girard told him that bills of exchange on New England had little credit in Philadelphia, because the people of that region were "somewhat given to sharp practices." If he really intended to buy a farm, the wisest course would be to invest five thousand livres at St. Domingo 
in coffee, sugar or syrup, and ship the goods to Philadelphia. In that event, if the merchandise arrived it would be easy, with the proceeds, to buy a farm which in times of peace would be worth forty thousand livres money of St. Domingo. As for himself, he was about to set off for Egg Harbor, where was a schooner of fifty tons, which he had recently bought and proposed to load with lumber and tar and send to Le Cap consigned to Jean.

In this new venture Girard was not alone. With him were associated "M. De Neuville and Captain Marc who is to be in command," and "M. Baldesqui, captain in the corps of General Pulaski," a gentleman with some ready money with whom Girard had just formed a partnership. His reasons for taking this venture, he wrote Baldesqui, were that "Sales are very slow, money has gone up twenty per cent. and I am afraid that many will fail altogether. I have, therefore, taken one-third interest on account of our partnership in a schooner now lying off Egg Harbor and belonging to M. Le Chevalier de la Nau." Their one-third interest cost fifteen hundred livres. He was quite aware of the risk of the sea. If, therefore, Baldesqui had any fears for the safety of the vessel, or did not wish to embark in such a speculation, his interest could be sold and the funds invested in merchandise.

The schooner was not destined to make the voyage to Le Cap. Captain Marc went to Virginia, fell sick, and wrote Girard to sell his interest and get another captain. Girard accordingly bought the share of Marc for "fifteen hundred livres, Continental money," and late in October, 1779, the Minerva, commanded by Arthur Helme and carrying twelve cannon and a crew of seventy men, sailed from Philadelphia as a privateer. 
October twenty-fifth she was off Cape May and soon on her way to Sandy Hook to cruise for prizes; but a series of gales drove her south of the Capes of Virginia and a fortnight passed before the cruising ground was finally reached. There the weather was hard and cold and finding that the vessel made a great deal of water, that the deck leaked at every nail head, that the crew was continually wet and cold and unable to stand the weather, Captain Helme bore away for the coast of Georgia in hope of making a good cruise in a southern latitude, and November twentieth, when in latitude thirtytwo, sighted, some forty-five leagues off the coast, the dismasted wreck of a new Virginia vessel loaded with tobacco. In the cabin and forecastle were several dead bodies. From her were taken an anchor, a few muskets and cutlasses, and a Hadley quadrant bearing the name Edward Green. On the day following, the Minerva ran into a gale so heavy that Helme was forced to throw into the sea the four and six pound cannon "expecting every moment to follow them to the bottom."

The gale abating, Helme started for Philadelphia; but, falling short of provisions, put into Horn Town, Chincoteague, Virginia, losing a part of the false keel in so doing. The crew was discharged and the news, with an appeal for money, sent to Girard. Aware that his privateering venture, at least for the present, had failed, he instructed Helme to strip the Minerva, store all her furniture on shore with some honest man and bring the receipt to Philadelphia. Helme replied that he would gladly do so if he could, but, unhappily, an honest man was as hard to find in Horn Town "as virtue in the present contest." Therefore, he was resolved to strip the schooner, store everything on board, stay himself, and, with the help of a boy, care for the property. Girard bade him buy a 
cargo and sail for the West Indies. This he found impossible. Not a barrel of pitch or tar was to be had. Congress had forbidden the export of provisions, and no lumber could be bought, for such had been the drought that not a mill was working. Moreover, the cold had been so intense that the bay was frozen "from the beach three miles seaward, something very singular." April would probably come before he could sail. The warlike stores, carriages for four pounders, shot, hand grenades, sponges, hammers, ladles, cartridges, cutlasses, muskets, boarding pikes and match rope might be sold to a firm then fitting out a privateer; but what price should he ask? Some powder had been sold at thirty-seven dollars a pound. Provisions were high and hard to get. Pork cost 680 dollars a barrel. Coffee, by the quantity, fourteen dollars, and tea forty dollars per pound; rum, 120 dollars a hogshead, and lard seven to eight dollars per pound. Late in March, Helme at last made an attempt to put to sea in ballast, but ran on the bar and so damaged the Minerva that the repairs cost 2250 pounds, Maryland money, and May came before he finally set sail for Philadelphia.

While this first venture in privateering was thus coming to naught, the appeals for business produced some results. From his brother in Le Cap came a consignment of coffee with the request to keep one-half the profits and hold the rest, as it was his intention to buy property in Philadelphia. He was doing so well in business, however, that he expected to remain some years. Then, if the climate of San Domingo had not ruined his constitution, "we shall see."

From a firm at Le Cap, through the good offices of the brother, came a consignment of I49 muskets, worth 6705 livres, part of eleven hundred, of which the rest would be sent later. These Girard was not to sell for 


\section{THE LIFE AND TIMES OF STEPHEN GIRARD}

paper money, and, after deducting his commission, was to remit the balance in flour or salt provisions.

Both consignments were sent in the ship "Adventure." She was well named, for on her voyage northward she was captured by the British, retaken by D'Estaing and returned to her original owners, who sold ship and cargo at Charleston.

The arrangement with Baldesqui, whatever it was, seems to have been agreeable to both and on the first of February, I780, a formal partnership was formed and the firm of Stephen Girard \& Co. established. The capital was to consist of interest in vessels, outstanding debts due, amounting in all to thirty thousand livres Continental money, of which twenty thousand belonged to Baldesqui and ten thousand to Girard. With this capital, Girard was to engage in commerce and traffic on common account, reserving to himself the right to acquire for himself, his brother or his father, real estate and negroes, provided such acquisitions were not made with money belonging to the partnership.

Among the assets of the new firm were two schooners, the unfortunate Minerva and the Whim, and a share which Girard owned in a third trading with St. Eustache. Each adventure ended badly. The Minerva was wrecked on Chincoteague Island, Virginia; the schooner in which he had a share was seized when the British took St. Eustace, and the Whim, after two voyages, was sold for salvage.

This little vessel, purchased for a few hundred pounds, is first mentioned by Girard in a letter to his brother Jean in February, I780. "We have here a schooner, the Virginia Pilot Boat, which I am about to dispatch to Le Cap, consigned to you, commanded by Captain Williamson, a man you know." But by the end of March, when, 
with a cargo worth 7832 livres 18 sous, or about 1450 dollars, she sailed for Le Cap, it was "From on board the schooner Vaine" that the captain reported his arrival at Reedy Island. Girard in a letter to his brother calls her The Whim and describes her as small, but a very fast sailer. Baldesqui, who left Philadelphia for St. Eustace on the first of April, "was much surprised to meet our little schooner at the foot of the river. She was going out the same day as we. She seemed to sail very well, but she was a little thing compared with the boat on which I was."

Le Cap was reached, and with a return cargo costing 7826 livres she came back to Philadelphia. On her second voyage, while coming out from Le Cap, she was taken by the British, and in a few hours recaptured by a privateer under Captain Fleming, who brought her to the Môle.

Baldesqui, then at Le Cap, wrote, "It appears that we are not lucky in our ventures because, in spite of the arrival of our schooner Whim, we have lost on her last voyage. What is worse, besides the fact that her cargo did not sell well, she was captured on her return. Happily, or unhappily however, she was rescued a few hours later and brought to the Môle.

"The proper thing would have been to let her depart at once but the courts of this country, always hungry (joined to the bad advice given to the rescuing Captain that he had some claims on the recapture and which led him to make a declaration contrary to the letters he wrote your brother) have detained her for a month at the Môle. Messers Musculier and Rondinau told us that they believed she would be condemned, but we have heard by the last post that she is released. We shall be fortunate if we get off with two thousand livres costs." Jean Girard, who had taken a partner and founded 
the house of Girard \& Hourquebie, reported that "Messers Musculier \& Rondinau wrote us that the Court had decided that she might proceed on her voyage and that the costs were very great. We have already paid out $65^{\circ}$ livres and these gentlemen notify us in their letter of the 8th inst. (August) that Captain Williamson has asked that part of her cargo be sold to pay the balance. They do not know how else to obtain it."

The Whim, however was not released. "You will be much surprised," wrote Girard \& Hourquebie, "after our letter of the I 4 th inst. (August) when we tell you that the cargo of the schooner The Whim has been sold at the request of Captain Flemming to whom the court awarded a fifth as his share of the prize, and that the proceeds were not enough to pay the costs. This is the news sent us by Messers Musculier \& Rondinau by their letter of the $22 \mathrm{~d}$ inst. at the very time we supposed the schooner ready to sail."

Girard \& Hourquebie were inclined to suspect Musculier \& Rondinau of dishonest action in having "the boat condemned and thereby gaining more profit for themselves." Baldesqui was sure of it. "Our little schooner and cargo have been sold to pay the demand of $1 / 5$ made by $\mathrm{Mr}$. Flemming for having recaptured the boat and to meet the expenses of the Court. It is as clear as day that this is a knavish trick on the part of Messers Musculier \& Rondinau, nevertheless this little venture will not return us enough to buy a toothpick unless, as on the last voyage, you took precaution to insure her."

Baldesqui was then at Cap Français. The partnership formed, he set sail for San Domingo to settle his own affairs and seek business for the firm. A voyage of fourteen days, during which the ship was chased and almost captured by a frigate, brought him to St. Eustache, 
whence he wrote, "I do not know what will become of me. They say there has not been one opportunity for San Domingo in eighteen months. And to add to this misfortune, I have too much cause to fear Captain Doane will not go to San Domingo as we understood he would * Ah this cursed country! I do not know whether you have seen it, but I have never found anything which approaches it. There is here a swarm of men, from all parts of the world, only desirous to settle their affairs quickly and get away as soon as possible from the inconveniences of the island. The heat is insupportable. The cost of living is high. After a search of three days I have found lodging in a little corner which shuts in a miserable little bed. After much pleading on my part, they, as if for charity, have taken me for three gourdes a day."

All commercial houses at St. Eustache had correspondents in Philadelphia. Nevertheless, he brought the firm of Girard \& Co. to the attention of several and, finding that Captain Doane was going to Port-au-Prince, invested five thousand livres in codfish and butter, though told that San Domingo was overstocked with provisions. Those who sold him the fish cheated in the weight, and the arrival of a convoy of sixty sail at Cap Français, just before he reached Port-au-Prince, caused a sharp fall in prices, and two thousand livres were lost in the venture.

At Port-au-Prince he was forced to remain several weeks, for the enemy made the journey by sea to Le Cap too dangerous, and that by horse seemed too costly. A horse was finally bought for a hundred pistoles and after a trip partly by land and partly by sea, he arrived to find his affairs in disorder. Matters were not as bad as they seemed, and in December Baldesqui returned to Boston with more money than he had expected. 


\section{THE LIFE AND TIMES OF STEPHEN GIRARD}

Meantime the business of the firm prospered. Consignments came in from St. Eustache, Cap Français and Port-au-Prince; good sales were made in Baltimore, and Girard, on his own account, purchased from Ezra Stiles a house and three stores adjoining in Water Street. His letters at this time are of interest as showing the state of trade, the extent to which the currency of the country had depreciated, and the great sums paid for food and drink.

A correspondent, writing from Fredericksburg in October 1779, states that a hundredweight of tobacco cost $£_{1} 8$; country salt $£_{15}$ the bushel wholesale; French salt £20; rum $£_{12}$ the gallon; brown sugar $£_{120}$; coffee $£_{125}$ per hundredweight; lump sugar $£ 8$ the pound, and that "there is neither linen, nor cloth, nor hardware, nor pepper, pins, or writing paper. All these articles are in great demand as well as powder and lead."

At Richmond, November 1780 , rum was $£_{25}$ to $£_{30}$ per gallon; molasses $£_{14}$ to $£_{17}$ per gallon; sugar $£_{350}$ to $£_{45}$ o per hundredweight and coffee $£_{15}$ to $£_{20}$ per pound.

A Baltimore correspondent to whom he sent twenty barrels of sugar wrote, "I am sorry to inform you that West India produce is at a stand, and particularly the price of sugar is likely to fall as there are great quantities of Spanish sugar in town and more coming daily from your city. Tobacco is not to be had here at present, a fear of the enemy's picaroon boats that have for a long time infested our bay has prevented tobacco from being brought here." Bohea tea was selling at $£_{4} 0$, Maryland money, per pound avoirdupois. Spanish sugar brought eighteen dollars, Continental money, per pound; coffee twenty-five dollars a pound; loaf sugar forty dollars a pound; India rum $£_{35}$ a gallon; Muscovado sugar four hundred and sixty to five 
hundred and forty pounds a hundredweight, and flour from eighty to ninety pounds a hundredweight. The sugar finally sold for $£ 21,634$ 15s. 2d., Maryland paper money, and the barrels for $£_{I I} 5$ s. each. For butter bought at Bordentown, New Jersey, Girard paid thirteen dollars a pound, and forty dollars for the firkin which contained it. A correspondent at Baltimore wrote that gold was so scarce that it was not possible to convert his paper into specie, which "was used only for one thing, that is bottled wine which is sold for five shillings a bottle paid in specie." He then asks if "a venture that I can send you of eight or ten barrels of flour per wagon would pay expenses from Christine here and return. It would not exceed some $\$ 2500$ or $\$ 3000$ each." Flour was then selling for one hundred and twenty-five dollars a hundredweight, brandy at sixty dollars a gallon, and raw sugar at five hundred dollars per hundredweight. This venture, proposed in March, I781, was not undertaken because "the wagons which could be hired at that time for \$1800," could not be had in April for less than $\$ 4000$. In May Baldesqui wrote that in Boston "paper money has no longer any value, some taking it at two hundred, others at three hundred, others at four hundred," and added, "may the Devil carry off all the paper money and the people who invented it." In June, "Paper money of the old issue has no longer any value here, the new passes at four for one. I am in it for \$30,000. I do not know what to do with it. I hope you have been more prudent than I."

Baldesqui had intended to leave Boston for Philadelphia as soon as a cargo of dry goods from Le Cap was sold; but, ere he had disposed of it he was deep in another speculation in which he hoped to interest Girard. "By your last which I received at Cap Français, you seemed 
to desire my return having, as you said, a wish to make a voyage. An opportunity presents itself which squares with your plan. A new brig of 136 tons, armed with sixteen cannon of fours, built with the utmost care and especially for fast sailing has been offered to me.

"Send me then, I beg you, by the first post, the price of all the combustible goods which you think most desirable for prompt sale, that I may calculate the possibility of making good the insurance and cost of sending it to you in Philadelphia where you will be able to take command of it, and where we can plan together the way to get the most advantage out of it. In case your reply prevents me from carrying out the business, and you still intend to make a voyage, we shall be able, on my arrival at Philadelphia, to have one built to suit you in which you can go."

Letters from Girard during 1781 and 1782 cannot be found. What took place between him and his partner can only be gathered from the letters of Baldesqui. The reply to his proposition concerning the brig seems to have been unfavorable, for the next letter from Baldesqui announces that he has bought an interest in the brig, that he wishes to send her to Philadelphia laden with a hundred thousand weight of sugar and a hundred thousand. weight of coffee, but fears he may not be able to put it into execution because the underwriters having had such heavy losses have raised rates of insurance twenty per cent. "I am mad as a dog. If this speculation is impossible it seems best to send her to Port-auPrince with a cargo of wood, to return to Philadelphia, and, if I can, to interest the firm there for one-sixteenth. As to the warehouse of which you spoke to me, I understood by your previous letters that you have established one there and made it a storehouse for fuel. However, 


\section{TRADING AND PRIVATEERING}

keep it or not, just as you think proper for the best of our interests. I am not unfavorable to the plan you have to increase our business and will do everything in my power towards it."

The Flora, so the brig was named, is described as carrying four cannon of four, two of nine and eight of wood mounted on gun carriages, and manned by a crew of twenty-five. The brig and cargo, at the request of Baldesqui, were insured for $£ 2000$, hard money, at forty per cent. "I mean," he wrote "pounds Pennsylvania currency as I imagine that is what you have already negotiated. I foresaw your decision relative to interest in the brig Flora, for which you no longer care. You are right. It is much better to have all our capital together in Philadelphia, and I am going to arrange some way to carry all with me so as to have everything together at the same time and place.

"Because of the news you give me of the value of specie, I am going to collect as large an amount as possible. There is some chance here, however, that paper will regain credit, because a French frigate has arrived bringing $\$ 7000$ in hard money and it is reported that a second vessel will soon be here with a considerable sum. Paper is still 75 for one, and seems able to sustain itself * * I believe the brig Flora will sail from Portsmouth in four or five days. I must go there tomorrow to give the order and hasten her departure. As to La Marie Française I know nothing except that she is on her side for repairs. On her way to Portsmouth she was caught in a frightful gale and injured. Patience! This cannot last forever, and as Dr. Panglos said, "All is for the best."'

By March, Baldesqui hears from Girard of "the loss of our interest in the brig" which had sailed for St. Eustache. "I was sure of it when I heard of the capture of 
St. Eustache by the treacherous English. May Hell confound them! But patience, one must know how to accustom one's self to misfortunes as well as to good luck.

"I cannot, however, refrain from observing to you in passing that $I$ fear you have not used as much caution in this affair as this kind of commerce requires, particularly when one is not more lucky on the sea than we seem to be. I wish to say that having heard of her arrival at St. Eustache it would have been prudent to have insured her, at least for the return voyage.

"I arrived from Portsmouth the day before yesterday (March 27, 178I). I went there to dispatch the brig Flora, which I believe went out last Saturday. She swims like a fish. She went from here to Portsmouth in four hours and a quarter with an ordinary wind. If she is captured we cannot depend on any vessel $* * *$ Perhaps I will await her return here, which should not be later than two months and a half, with the intention of having her sold and buying her for myself, or for the account of our firm and sending her to you in Philadelphia * * *

"La Marie Française has not yet sailed and will not be able to go for at least a month. Part of her keel was carried away in going to Portsmouth so that she is laid on her side for repairs. So you see that I am not more lucky here than you are in Philadelphia for I estimate that this delay will cost me some 50,000 livres at least."

Baldesqui now broke a leg and his letters abound in references to his condition. As to the Flora she had sailed on the fourth of April. "I have kept only a threesixteenths interest in this boat. The outlay cost 240,000 livres this currency, and I have paid 1500 livres specie on insurance. If she returns safe I expect to have a legal settlement and buy her for myself, or for account of our 
firm. As to the ship La Marie Française, Capt. Jean Revol, I am still owner of two-thirds of her cargo. The delay of this expedition makes me agree with you on this subject, although this is the only venture of this kind which has been made from here since the tornado at Martinique. The last news from there states that masts bring a very high price. However, if I can find a sale for all or part I will do it. * * The two-thirds of this cargo will amount to from thirty to forty thousand livres. It will comprise masts of from 22 to 26 inches in diameter and long in proportion, and after these all the lumber, staves, axles, hoop-wood, \&c. which can be well stowed in a boat of about four hundred tons.

"If, after this description of the cargo, and this estimate of its cost you wish to dispose of a part or the whole, for hard money, I will leave the control of it to you, and we will reserve this capital for some other enterprises. If this ship, however, arrives at Martinique, she will make, I think, a sale of at least 400,000 livres for which we would have to pay about 33 per cent. for the freight. * * It seems that they will soon place no value on paper money with you. It is falling in value here daily. I sold $\$ 2000$ last week at 90 for I, though the exchange still seems to be at 75. I assure you if I had not an engagement to fill I would not have been willing to sell it at I 20 for I."

In July the Flora was back at Boston. "Sometimes, my dear friend, one meets with good fortune. The Flora has arrived in twenty days from Martinique, where the sale of the cargo produced only enough to bring back fifty hogsheads of syrup. The rest of her cargo is freight. She returned in compliance with our orders, armed with ten cannon and a crew of fifty men, in company with another brig armed with six cannon. They had an enVol. I-3 
counter in latitude 28 , with a charming ship of 250 tons armed with twelve cannon of six and nine. They captured her and brought her to this port, without accident, yesterday. She is loaded with Madeira wine and gin. The invoice of the cargo, which was brought to me yesterday amounts to between four and five thousand pounds sterling. This good fortune makes the voyage of the Flora a success; without it the venture would have been ruinous."

Baldesqui now turned to domestic trade, and thought of sending wines to the French army. "The scarcity of ready money here makes business very dull, and one can dispose of merchandise only with great difficulty and at a great disadvantage. I shall be very glad to know the price of letters of exchange on the French army in your city, as I may be able to make something out of it." A few weeks later, early in September, he has decided to make the venture and send about thirty thousand livres worth of wine, brandy, rum, \&c. He fears, however, that it will be useless, for the report is current that the French are marching toward Virginia.

The army to which Baldesqui sent his wine was that of Washington, which had started on the Yorktown Campaign.

Associated with Baldesqui in his wine speculation was M. Nau, to whom, at Poughkeepsie, Girard now wrote offering his good services to dispose of the liquor in Philadelphia, and sent prices current. The offer was declined, a part of the wine was sent to Albany, and Baldesqui, having disposed of his share in La Marie Française at a loss, and made some foolish investments, took the advice of Girard and set off for Poughkeepsie to find that the proceeds of wine sold was not enough by $\$ 600$ to pay freight and expenses. What remained unsold was sent to Philadelphia and in January 1782 was followed by Baldesqui himself. 
The second year of the existence of Girard \& Co. was now drawing to a close. On the whole Baldesqui had not proved a profitable partner. No new business had been obtained by him; his West Indian trip had ended in failure and his money, instead of going to enlarge the capital of the firm, was frittered away in ventures made on his own account. Volatile, unstable, too prone to give advice, wanting in all that leads to business success, he was not the sort of man to be a partner with Girard. When, therefore, the second year of the partnership ended Girard requested, and then insisted, that the firm of Girard \& Co. be dissolved and that Baldesqui withdraw the capital he had contributed. Settlement of the affairs of the firm caused a dispute which later in 1782 was submitted to arbitration.

Of the complaints Baldesqui laid before the arbitrators no copy exists; but from the reply of Girard to some of the charges it may be seen what they were. Baldesqui complained that Girard had not "put his proper and particular funds with the partnership." To this Girard replied that it would have been unjust to have put in a sum equal to that of his partner because all the business of the firm was to be transacted by him alone. Therefore he had kept a sum to be used in part payment for the house in which he dwelt. The price was $£_{1300}$, and not having the amount in hand he was forced to put up for sale his estate at Mount Holly. "Please to observe that at the same time Mr. Baldesqui was in Philadelphia Mr. Girard mentioned the affair to him, as well as the resolution he had taken to sell the Mount Holly Estate, to which Mr. Baldesqui did not seem to make the least difficulty, and only said he wished to be concerned for one-half in the said purchase. Mr. Girard answered if he took the place he intended it for his own proper and particular account." 
Baldesqui complained that a commission had been charged for selling sundry articles for his private account. The answer was, "Stephen Girard never promised to do his particular business Gratis. Consequently," he was "in the right to exact it, and the said Baldesqui instead of complaining should think himself happy to have a house in Philadelphia (to which he never was of the least utility) that has done his business for half commission when the other half goes to the credit of said Baldesqui as partner."

To the charge that Girard had purchased three stores "On speculation and for twenty years," the reply was, they had been "purchased forever," and that in payment Girard has given his own private money and credit, and the question was asked of Baldesqui, had fire consumed them would "his generous soul have reimbursed Stephen Girard the half? No, to the contrary." Indeed, he said, had they been bought on account of the partnership Baldesqui would be justified in leaving the loss on him, for he had never received authority to buy real estate for the account of the firm.

Passing in review the reasons for taking Baldesqui as a partner and his value as such, Girard states, that in January 1780 , Baldesqui promised, if the partnership were formed, he would sail at once for Cap Français, would send thence merchandise to the value of 60,000 livres, which sum should be added to the capital of the firm, and that he could procure for Stephen Girard \& Co. "the most of the consignments that might be made from there to Philadelphia." On the expectation that the promise would be made good the partnership was formed. Did Baldesqui suppose it "was the imaginary sum of £ro,000 continental money, value in different effects, interest in vessels, debts or bills the half of which are lost, unbalanced 
or unsold, when Stephen Girard had in the partnership $£$ Io,000" and in private property and credit "a sum much more considerable than the full amount of the whole stock of the partnership that led to the founding of the firm of Girard \& Co.?" No. "Mr. Baldesqui might clearly see that Stephen Girard took him in company from the hope that he had that the said Mr. Baldesqui should have performed the promise he had made to Stephen Girard," which he never did. At St. Eustache he procured but one shipment to the value of £101:16:6. From Port-au-Prince he sent but one invoice valued at first cost at fourteen joes. In short, he had "not procured from thence any commission to the house of Philadelphia that the profits arising therefrom could purchase a tooth picker." The decision of the arbitrators, which seems to have been in favor of Girard, caused no ill feeling. During a year and more friendly letters passed between the old partners, and Girard from time to time made some small purchases for Baldesqui, who, on one occasion at least, invited his old partner to visit him at Germantown.

While Baldesqui was engaged in his wine speculation, Girard went back to privateering, and with Messers Ramsey and Cox, late of New York, fitted out a barge called The Recovery, put Captain Gear Chadwick in command and sent him with some smaller craft to cruise against the Tories on Chesapeake Bay.

The plan seems to have been to capture slaves from the Tories and sell them, perhaps, at Baltimore. As to their value at that city a correspondent was consulted and replied: "As to the business which you have confided to me, I have taken all the information possible relative to the sale of negroes. From this I see that it is very difficult to estimate their value without knowing their appear- 


\section{THE LIFE AND TIMES OF STEPHEN GIRARD}

ance, their ages, and, in fine, their physical condition. However, I can say that you may expect to sell them at from fifty to two hundred pounds. So if your privateer is fortunate, as I wish she may be, the cost of a trial will not amount to much." The trial was made and in June Captain Chadwick reported results. He was at Onancock in Virginia on the eastern shore of the bay with a little fleet of four boats, the barge Recovery manned by twenty men, a second manned by twelve, a third by eight, and a fourth by six. His prizes were a sloop carrying four hundred bushels of corn and oats, a whale boat in which, when captured, were five valuable negroes, a six oared yawl, and a small schooner from Portsmouth, the William and Polly, laden with pieces of merchandise "not worth sending" to Philadelphia. The force of the enemy consisted of four barges and two or three small privateers manned by negroes. On an island not far away the enemy had gathered many negroes and much plunder which Chadwick hoped to seize.

With this letter all record of his doings ends until proceedings were begun in the Admiralty Court at Baltimore for the condemnation of the prizes. What there happened is told by his correspondent. "This," August twentieth, I78I, "was the day the Court of Admiralty was to have been held for the trial of captures of your boat Recovery. The judge attended in town, but the lawyers being absent the trial is put off until Thursday next, at which time we hope there will be no further delay. I have nothing very material to inform you of more than Hamilton, the Deputy Marshal, sold three of the negro children, two boys and a girl. The title being so much doubted they sold very low. Smallest boy sold for $£_{3}$ I:IO; largest boy for $£_{36}$ : ro, and the girl for $£_{39}$.

"Mr. Hugh Young who supports the claims for the 
Negroes taken from Lowrey threatens much and says he will risk half his worth to recover the negroes and get satisfaction of Captain Chadwick. He says if the negroes should be condemned, which he does not expect, he will replevy them and have another trial for them. However, there cannot be much thought of what he says being concerned. The trial will determine the justice of the matter."

That same August day Girard wrote to Captain Chadwick and to his correspondent in Baltimore, George P. Keeports, instructing them to sell the Recovery. Mr. Keeports replied:

"Agreeable to your desire I have enclosed for you an inventory of the materials of the barge Recovery. I have offered her by private sale, but cannot find any person inclined to purchase. I shall try her by public sale on Monday next; but am fearful she will not sell for near her value which if she does not I shall purchase her in for the owners and await your further advice. The schooner William and Polly is left at the Head-of-Elk, in care of Mr. Zebulen Hollingsworth, by Captain Chadwick who informs me she was aground and could not be got off when he came away. A person who is inclined to purchase her and will give $£_{I} \mathrm{IO}$ for her is going up to look at her and if she answers the description given by Captain Chadwick, the bargain is made. If not he is to bring her down here for which I am to allow him for his trouble. There has not been a trial yet. Thursday last was the day the trial was put off to, but Mr. Chase could not attend. It is further put off to Monday next when it will certainly be. I am sorry to inform you that it is my apprehension Captain Chadwick will hold the weakest side for those negroes he captured on the land, as he has no person to appear as an evidence but himself, and I am fearful of success." 
When at last the trial did take place Keeports gave this account of the proceedings to Girard: "The Court of Admiralty sat Tuesday last and have condemned all the prizes libelled against excepting the five negroes taken in the barge (and are now run away) which the Judge has ordered to be returned to the claimants when found for which the claimants have sued Captain Chadwick. The six negroes taken from Seldon and the eleven taken from Lowrey the judge has not given his opinion about as yet. He has put off his determination to the roth instant (September roth, I78I). It appears from the judge's inclination as if he would condemn them if possible; but the point seems very critical for him which is his reason for requiring so long a time to determine the matter. Captain Chadwick is likewise sued for those negroes taken from Lowrey and Seldon for the whole of which suits I've become special bail for his appearance in November Court in which matter I wish to be instructed from you in your next letter, that is whether you will indemnify me as his bail if there should be any unexpected accident of Chaptain Cadwick's not appearing.

"I informed you in my last of the schooner William and Polly being at the Head-of-Elk, where she still remains, and of a person that wanted to purchase her that has since declined his intentions. I shall strive to procure a person to bring her here as soon as possible, and if I cannot sell her shall strive, with your approbation to get her employed in something or other. The sale of the barge which was intended last Monday was postponed until I should have your further directions in the matter; but shall offer her for sale this evening as I am in hopes she will now sell. If she should not I shall purchase her in for the owners, and Captain Chadwick will try to man her for another trip. There is an embargo laid on all 
vessels here for the purpose of transporting 50,000 troops from the Head-of-Elk down the bay which will occasion the barge to be delayed a few days which is my reason for striving to sell her this evening."

The barge, accordingly, was put up at the Coffee House for $£_{150}$; but not a bid was made. All that could be obtained was an offer for a half share. Chadwick therefore set about preparing for another cruise and Girard was asked, if this failed for want of men, whether the barge should be sent to Head-of-Elk and taken across to the Delaware or sold for what she would bring. The attempt to man the Recovery came to naught. "The barge" Keeports wrote "cannot be manned here. The French fleet coming into the bay has baffled every prospect of profit in cruising in the bay. General Washington is just expected in town and everything seems a little in confusion to prepare for his reception."

September tenth the Court handed down its decision in the case of the negroes taken from Lowrey and Seldon and ordered them returned to their owners. Chase thereupon took an appeal to the Court of Appeals in Cases of Capture sitting in Philadelphia, and asked that the negroes be sold and the money left with the marshal till the case was decided. This the attorney for the claimants opposed, but agreed to take the negroes and give $£ 2, \infty$ bail to be paid to the libellants if the case went in their favor. Unhappily no entry of the agreement was made on the record, and when the agent for Lowrey and Seldon heard of it he refused to stand by the agreement and declined to receive the negroes. Thus left in the care of the deputy marshal till it suited the claimants to recover them they were hired by sundry parties to work for food, clothes and housing.

Chase now advised Girard to pursue the matter and 
demanded for his services, said Keeports, "the enormous and exhorbitant sum of $£ 50$, which he has desired me to inform you of, and request you may transmit me the money for him as soon as possible. The amount of the fees and charges, as per copy of account enclosed, I have become answerable for which you will likewise please transmit and give me particular orders about what you will have done with the barge. Captain Chadwick is going to the Head-of-Elk with two hands who will return in the barge and bring down the William and Polly. Captain Chadwick must appear here at court in November next to answer in five suits that are commenced against him for damages for those negroes he captured which were not condemned. I have become special bail for his appearance."

Girard replied that he could not help thinking that if Chase had the interests of his clients at heart and had attended court when he should, matters might have turned out better. The enemy did not hesitate to condemn to the captors effects of the same kind taken from within "our lines," and it was natural to expect that "lex retaliatis ought to take place." However, he never had encouraged proceedings of that sort and, though advised he might recover the negroes in dispute, would be sorry if the owners were deprived of their slaves, especially if friendly to the United States. He had therefore concluded that if the several suits against Captain Chadwick were discontinued no appeal would be entered. "The intolerable avarice of Mr. Chase" surprised him. Chase had already "been paid more than a Philadelphia lawyer would receive for securing the condemnation of prizes worth twenty thousand pounds." "When I first waited on him he gave me every encouragement to expect he would soon finish my business and hoped that all 
would be condemned, whereupon I paid him a generous sum of $£_{50}$, which is more than the voyage will net the whole owners of the barge." The deputy marshal, too, had taken advantage of him. Of his own accord the marshal had disposed of three young negroes "for less than one half what such sold for when I was present at Elk," and had made a charge of $£_{4} 6$ I6s. for the support in gaol of the Lowrey and Seldon negroes "though the most of them he hired out at work near all the time."

And now matters began to mend a little. The barge was sold for £ir7 Ios. "to a liver on the eastern shore," and a citizen of Baltimore went "security for the payment." The schooner William and Polly was taken late in September for "the public transport service," the transportation of Washington's troops, and three of the five negroes who ran away, having been returned to their owners, those suits had been withdrawn. New suits, however, were threatened. "Several different persons," Keeports wrote, "have been inquiring after Chadwick since he left this place, who lay very heavy claims to him and his first Lieutenant, Charge. The cruelty they have treated several with in plundering and distressing their families is horrid anä I do not remember of ever hearing of greater rascality than they are charged with, and from every circumstance I can be informed of, I am apprehensive that the sufferers will commence suits for the bonds given for Chadwick's good behavior when his commission was obtained."

When the case was called for trial, Captain Chadwick did not appear, but he arrived after the court had adjourned to the second Monday in January, I782. A letter from Girard expressed his belief that with Chadwick's return, Keesport would be released from the penalty to which he had become liable, and bade him not 
enter a new security on Girard's account. To this Keeports replied that as the trial had been put off to February he could not be released as security for Chadwick save by giving him up to the sheriff, in which case the Captain would go to jail. "I cannot account for your reason in this instruction, as you must certainly suppose that I cannot have any interest by being surety for Chadwick in a matter that entirely concerns you. I hope that you do not wish that I should take a risk on myself that you mean to avoid, for without I am instructed from you to continue bail on your account for Chadwick by the next post, I shall deliver him up which will be attended with expense and ruin for Chadwick and encourage the opposite party to prosecute the suits.

"I have proposed to settle the court charges for Lowrey and Seldon suits if they would have them struck off, but they continue to refuse settling. They have proposed having the suits struck off if Chadwick will leave it to arbitration and give bond with security that the determination of the arbitrators shall be final. If you approve of an arbitration to settle the matter you will please to instruct me, or inform me, how I am to act respecting the bail for Chadwick."

Alarmed at the prospect of going to jail, Chadwick wrote to Girard: "I think it very hard that I must go to prison, and for no reason but your not endemnifying Mr. Keeports in his bail for my appearance which I never have nor never will violate. Therefore I entreat you to write Mr. Keeports more fully and release me so that I may be with my little family and you, until the court. By my being delivered up to the sheriff it will not only give the opposite party greater advantages in influencing the people in favor of their suit, but renders me entirely useless and incapable of rendering us any service." 
The appeal was heard; Keeports was instructed to continue bail, and as the trial would not be held before November I 782 Chadwick went back to his "little family."

And now more bad news came from Baltimore. The schooner William and Polly after seizure for the transportation of military supplies was taken to the York River, where the hands ran away and left her plundered of anchors, cables, and sails. The purchaser of the barge disappeared and Keeports replied that he would be compelled to sue the surety; and that "the rascal Hamilton, the deputy marshall" had rendered another bill for $£_{12} 935$ 8d. Part was commission for selling two negroes, part a doctor's bill for tending sick negroes, and the rest for keeping sixteen negroes from September tenth, when the judge decided they should be returned to their owners, to some time in December, when the agent of Lowrey and Seldon consented to receive them. This the court ordered paid. An attachment was issued and when Keeports declared he had no money or effects of Girard with which to pay, a transcript was taken of proceedings in court in order to bring the case before the court in Philadelphia.

Girard submitted the matter to three arbitrators who agreed that the claims of the marshal arising before the tenth of September should be revised and adjusted in Baltimore, agreeable to the custom and laws there prevailing, by persons properly authorized so to do. Meantime two hundred dollars should be paid the deputy marshal, and both parties enter into an agreement to abide by such decision as to the rest of the claims as might be made in Baltimore by other referees. The schooner William and Polly was finally found in the possession of citizen of Portsmouth to whom she had been given by an officer to hold till claimed by her rightful owners. To 
collect from the quartermaster the sum due while she was in the service of Congress was next to impossible, and while endeavoring to do so a speculator offered $£_{75}$ for the vessel and the claim for her service. With this all record of the schooner disappears from the correspondence.

The suit against Chadwick dragged along for another year and more. "Since you were in Baltimore last," wrote Keeports in August 1783, "I have not heard from you respecting Captain Chadwick's suits for which I am his bail. Should be glad to have your instructions how to proceed, whether I shall forfeit the bail for his appearance which is $£_{100}$, or enter special bail for him. The court will be held next week and the trial I expect will be one of the first that will come on. You will therefore please to lose no time in giving me instructions on this matter also what I am to do with Mr. Chase, the lawyer, who still demands his additional $£_{50}$ fee."

Chadwick failed to appear in court, whereupon Keeports offered the £roo to the agent of Lowrey and Seldon if he would let the matter drop. He refused; but offered to take a thousand dollars in settlement or submit his case to arbitration. Should Girard accept neither, suit against the bail bond would be begun at once. Girard answered that Mr. Ramsey was not in Philadelphia and until he was consulted no decision could be made.

This letter was written late in October 1783 , and while settlement still dragged along, he received notice in January 1784 of a suit begun by Mr. Littleton Ward of Northampton County, Virginia, for damages received from Captain Chadwick in July 1781. "I have been applied to" Moses Levy of Philadelphia informed him, "by Mr. Littleton Ward of Northampton County in the State of Virginia. He complains of very great injuries he has received from a certain Gear Chadwick, com- 
mander of the armed brig Recovery, and from his officers and men. The amount of the damages sustained by his or their means has not yet been accurately stated to me, but from what has been stated, I am of opinion it cannot fall short of, though it most probably exceeds, one thousand pounds. My principal view in addressing you upon this subject is to give you notice in time so as to secure yourselves against Chadwick the aggressor. My instructions are of such nature that I must proceed in this business with all possible dispatch, and as you are the securities for Chadwick's good behaviour I am directed to point the action against ye."

The letter was addressed to Stephen Girard and Isaac Coxe. In a memorandum, probably the draft of a letter, Girard reviews the issue. "The reason why Mr. L. Ward has waited to the $3 \mathrm{~d}$ of January 1784 to make his demand for damages he pretends to have sustained in the month of July $178 \mathrm{r}$ by Gear Chadwick, commander of the armed boat Recovery, I can't comprehend, as it appears that the said Littleton Ward seized the moment of the absence of the said Gear Chadwick to make his unlawful claims against the owners \&c of the said boat Recovery in view that he should have nobody to contradict his demands.

"To suppose the laws and customs of the country should authorize the said Littleton Ward to make any demands whatever against the security of a commission given to a captain, particularly when it is out of the power of the said security to have their redress against the said captain, I shall represent that tho Captain Chadwick has sunk more than the full first cost of the said armed boat Recovery, the prizes that he has taken have been sold in the State of Maryland by order of the Judge of the said Court of Admiralty as per account rendered 


\section{THE LIFE AND TIMES OF STEPHEN GIRARD}

by the marshal; but respecting the conduct \&c of Mr. Littleton ward during the last War with Great Britain, I shall refer myself to the answer to the interrogation made by order of the Supreme Court of the State of Pennsylvania to sundry inhabitants of Northampton County, State of Virginia." When the trial came on in the Supreme Court of Pennsylvania in October 1786, Ward was non-suited. But the end of the trouble caused by the Recovery was not yet. In October 1788 Keeports was sued by Cary Seldon and John Lowrey on the two appearance bonds, each for eight thousand pounds of tobacco, and once more appealed to Girard and receiving no reply wrote again in April 1789 . He was in great distress; the time had elapsed and judgment would go against him, in the court then sitting, for the amount of the bonds, costs and lawyers' fees. Not the least favor in time or indulgence after judgment would be given him. Girard replied, I "observe your disagreeable situation respecting the bonds which you say to have given for Capt. Chadwick's appearance, the time being elapsed you are afraid that a judgment will be given against you. I must confess that I am not any way apprehensive of such injustice from your courts, but should it be your case I think the money belonging to the owners of the barge Recovery, which sum you detained in your hands this great many years, put together with the interest due thereon will be more than necessary to pay your judgment, lawyers' fees, \&c." 


\section{CHAPTER II}

\section{THE TWO BROTHERS}

THE return of peace, the opening of the ports and the revival of trade, sent Girard back to his old rut and once more turned his thoughts to the San Domingo trade. Ships he had none; but consignments, for a time, were sent as freights in the ships of other merchants. To his frugal mind this was a poor way of doing business. When his goods were carried in the ship of another the freight paid was his share of the expense of the voyage, of the interest on the cost of the vessels, of the insurance and the profit of the owner. Far better to own both ship and cargo and receive all the profits. This Girard resolved to do and having so decided began to look about for a brig he could afford to buy. He had always in mind, he told his brother, "the purchase of a brig to trade between Philadelphia and Cap Française," and proposed that Jean or one of his friends at Le Cap should take a half interest and so balance commissions.

While searching for a vessel, staunch, well built, and within his means, he looked forward to the time when he might go in her to Bordeaux; but the old debts still stood in the way. He had, indeed, made some attempt to discharge them, and from Le Cap had sent to his father a consignment of goods to be used to liquidate a part of them. Hearing nothing from the father he now wrote to his brother Jean, just returned from Bordeaux, and asked what had been done.

"I see on reading your letter to myself" was the reply, "that you ask for news of the funds you sent our father. There were several attachments on it and it was sufficient to pay some of them. You have a balance of Vol. I-4 
6,000 livres to pay, but I believe that many would come to terms. You do not say a word about Pailher who has presented me a note against you for I 200 livres. I will wait until you speak of this to me before writing him. Take your own time."

Pleased by this news he forwarded two bills of exchange amounting to 2620 livres tournois, and asked for the good offices of his father to induce the Bordeaux creditors to accept payment in one year or eighteen months.

"The desire which I have to make a trip to my native country, to have the pleasure of embracing you are the reasons which force me to ask this service, and I hope you will be willing to grant it."

The bills came safely to hand, but unhappily, said the father, the one for 2500 livres was worthless and at once protested. "With true pleasure," Girard wrote back, "I received your letter, of July 29th and August $30 t h$, containing the protest of the note of 2500 livres. This is very unfortunate considering that it came from some money laid out to help a man who, in return, has tried to cheat me. I see that you have settled with Messrs. Laplace and Notte and have still in hand 322 livres, 7 sous. I will make a remittance to you in time. Perhaps it may be by a brig of two hundred tons which I am building which will sail from here next April, unless news of something more profitable sends her elsewhere."

The search for a suitable brig proving fruitless, he decided to build, and more eager than ever to find some one to share in the venture and balance commissions wrote his friend Balansun, at Le Cap, that he was about to build a brig of one hundred or two hundred tons, that she was to be used for traffic with San Domingo and that having invited his brother's firm to take an interest made a like offer of a quarter to him. One half he should keep 
for himself, and had no doubt that by combining industry with economy the voyages would be profitable.

Jean was told she would be of one hundred or one hundred and twenty tons, would cost about 4000 piastre gourdes, and properly managed could not fail to yield good returns. By September she was to be a brig of one hundred and fifty-five tons, because of the bulkiness of the cargoes (lumber and hogsheads of molasses) with which she was to be freighted. The cost would be about I2,000 piastre gourdes, one half for the cargo, one half for the boat. The first cargo was to be five hundred barrels superfine flour, five hundred barrels of dry herrings in coarse salt, and the remainder in lard, hams and sugar staves. The venture could not fail to succeed "because we will be in a better position than any one else to engage in the trade, not only for selling the cargo, but to despatch the return cargo promptly." Girard therefore again urged his brother's firm and M. Balansun to take an interest in the brig, described her as a two decker, well designed and well built and capable of carrying sixteen hundred barrels of flour, and asked his brother to procure a permit for her to enter Le Cap with five hundred barrels of salt fish and barrel staves.

Both declined the offer. Balansun because, "A speculation which has not yet returned anything to me, and requires a great deal of money, prevents me from taking the share you have the kindness to offer me in the brig you are building," and Girard \& Hourquebie because, "our Government will not permit English flour to enter here. Other articles made in New England are so abundant that this commerce presents a dull outlook." Prices, according to Jean, had fallen. American vessels had free entrance though there was talk of making them pay some duty. Flour was not permitted to enter the colony; 


\section{THE LIFE AND TIMES OF STEPHEN GIRARD}

but the authorities shut their eyes as there was no custom house at Le Cap. The best way was not to declare it, nor have it on the permit. Then it could be landed very quietly. At present flour could be brought in only by declaring there was none on board. Consequently American captains were forced to do so. His captain ought to be advised to anchor at Port François, as if he had mistaken it for some other port and should have a letter from him to M. Bell, a habitant of that place, requesting him to send the Captain's letter to Girard \& Hourquebie by special messenger, which could be done in two hours. Then, they could take the necessary steps. Port François was a fine harbor from which a vessel could easily go out, and where one could see the best places to anchor. To make the directions quite plain Jean drew a rough chart of the "baye du port François."

Girard was undecided whether to send the brig to Le Cap or to Amsterdam. If to Le Cap, he wrote his brother, she would carry a cargo worth 55,000 livres, and in fifteen days would be in port. The brother now announces that his partnership with Hourquebie is about to expire and should it be renewed he would have a thousand portugaise in addition to a capital equal to his partner. Should this sum be forwarded to Stephen, he would be glad to know on what terms a partnership could be arranged. But there must be no hard conditions. Should the old partnership with Hourquebie be dissolved how much would Stephen be willing to invest? Jean would have more than 50,000 livres. Girard replied that if he accepted the thousand portugaise it would be for investment in the equipment of ships or any other branch of commerce, but not for a share in all his business.

Just as his brig was nearing completion, and after much of her cargo had been bought, his brother sent 
more bad news. Le Cap was closed to Americans, the old tariff which excluded all profitable exports from America was again in force and cutters were cruising off the port to enforce the new restrictions.

"Our General is sending all American vessels to the Môle because of orders which he claims to have received from court. He is doing this under the old tariff which admits only wood and several kinds of live animals. Everything else is prohibited. Judge of the sensation this has made here! *** I advise you not to take any part in this commerce before you are quite certain of it, and to leave some one else to smart for it.*** I doubt whether the Court of France has given any order on this subject, and believe it is only a whim of this Sieur de Beltecombe. At the same time it will make a great difference to all the vessels sent from your ports. If the trade can be carried on under the French flag we will try to so arrange it."

The warning came too late to change the destination of the brig, otherwise Girard would have followed the advice and sent her to the Môle St. Nicholas. "Therefore," he wrote, "I beg you, as soon as you receive this, be good enough to send a petition to your governor asking permission for a boat you have purchased for trade with the Môle, to come into Cap Française and be dispatched thence immediately for the Môle. I will send you full authority to do this, so you will be able to follow my orders implicitly. Do not change this plan. Follow it exactly with great secrecy and promptness."

The next letter from Le Cap announced that not only was the General sending all American vessels to the Môle, but every morning a cutter went out to cruise off the port and prevent any strange vessel from entering. What American vessels ought to do, and three-fourths of them did, was enter at some other port. Girard was 
again advised to "let this commerce alone" till he was certain about it, and "let some one else suffer." At the beginning the authorities would be very rigid. At all events no vessels should come from American ports unless sent under the flag of France.

Early in April the brig was launched and, named Les Deux Frères, sailed for Le Cap. The event was no ordinary one in his career. Once before, during the war for independence, he owned a small brig; but the British took her. Never before had a vessel of which he was sole owner put to sea. At last he was fairly started on that mercantile career which was to make him in time the richest merchant in America. Her signal was "a blue flag, with thirteen white stars, flying at the head of the mizzenmast." Her Captain was Samuel Williams and Girard \& Hourquebie were the consignees. By another ship went instructions as to the disposition of her cargo and the treatment of the crew. If necessary to make her a French boat, in order to facilitate her entrance into Le Cap, Girard \& Hourquebie were at liberty to do so. The articles composing the cargo were of the best quality. The lumber was well seasoned, particularly that stowed at the bottom of the hold. The return cargo was to consist of one hundred hogsheads of molasses, thick, red, and of good flavor; twenty-five hogsheads creole raw sugar, coarse grains, pale red with no appearance of grey; fifty barrels of coffee well picked and large grains; twenty thousand pounds of soap, dry and packed in small boxes, and the balance in piastre gourdes. The brig would need nothing. Every Sunday the crew was to have fresh meat. The captain was to be paid six silver livres, money of the Colony, for each day at anchor besides eighteen gourdes as a gratuity for going and coming. Jean Girard was urged not to forget that this venture was of the 


\section{THE TWO BROTHERS}

utmost importance to the sender, to follow the advice of a true brother and friend, be prudent, not make him run any risks and tell his opinion of the captain. All things considered, Girard was "well pleased" that his brother's firm did not take an interest in the brig, which cost much more than he calculated. The outlay, for ship and cargo, was 8000 piastre gourdes. For her cargo, in which he had a seven-eighths interest, he paid 4500 piastre gourdes.

Hearing that his brother had a permit from the Governor and Intendant of the Colony to bring into port a boat purchased in Philadelphia, he suggests that the petition be made "in this way, that this is to repay some money which I hold in my hands for you, and as soon as your request is granted inform me of it. Then I will seize some opportunity to buy a boat which I will send to you for my own account or in partnership with you."

As the time drew near for the arrival of Les Deux Frères, Jean Girard hastened to the Môle to receive her, and, June I3, 1784, complained that he had been waiting sixteen days for the brig in order to send her to Le Cap, and again asked for an answer to his offer of partnership. That day the brig arrived but the Captain could not, he reported "get to speak" to Jean Girard "for, theay hearing some accounts of the Pleague in Baltemore theay brought me tow under a Battery on the Point open to the westerly winds wich blew fresh at this time whear theay made me Ride Corranteen four days in a bad situation." All possible dispatch was then made for Le Cap, which was reached with the flour in bad condition caused by the heat of the lumber.

The narrative of Jean Girard is somewhat fuller. He had great trouble to get her away from the Môle; had to pretend he was sending her to Jamaica in order to avoid paying the duties, and would not willingly find himself 
in such a position again for any one save his brother. Spain having taken off five thousand barrels of flour for Havana there was a chance of great profit on that in the cargo. But no; the too fresh lumber had heated and spoiled it. "You have chosen to take your own way and not to follow my advice. I have always said that it is much better to pay three or four shillings more for a barrel of flour and have the best in the market. But no, you have wished to economize in this, and mix much of the poor grade with it. This common flour was taken out first and sold to the bakers. They would have paid ten gourdes for the best quality, but I doubt whether I can get an average of $61 / 2$ gourdes per barrel for this. Some barrels which are branded Rainol Tukaoch Brintons \& Co. are not worth two gourdes. Among the best brands of flour the Shaw and Redclay is the best. This makes me think it is not the heat of the hold which has spoiled it, for in that case all of it would have been spoiled. Some was hard as a rock, much had a bad odor, was spotted with yellow and could "only be used for sea biscuit, or bread for the negroes." The value of the cargo, flour at 63 livres a barrel, lard at 27 , herring at 48 , shingles at $4 \mathrm{I}$, staves at $35^{\circ}$ a thousand and planks at $34^{\circ}$ a thousand would be between fifty-four and fifty-five thousand livres, yielding a profit of some $\$ 5600$.

To obtain a return cargo was difficult. Continued rains made it impossible to get sugar. How to conceal the coffee and sugar Jean knew not. "Your hold will be half empty, although for this reason I have bought fifty hogsheads of excellent tafia at 1291/2. You have not asked for this, but would you be willing that I should expose your boat to danger of capture by letting her sail without good ballast? There is no freight here, business is so dull." And well it might be, for during the last days 
of June, the town of Port-au-Prince was burned, five of the richest islets laid in ashes and a number of people at Le Cap ruined.

While waiting for the return of Les Deux Freres, Girard answered the proposition of his brother. As to the thousand portugaise and the proposed business connection he should be glad to know in what branch of commerce his brother wished to take an interest. If in general commerce he could put in at least double that sum without including his real estate or household goods, and would not have to draw from the capital for house expenses: "In fact, from the rents which I receive I find myself lodged for nothing and have from 150 to 200 livres over, enough as you must have noticed to maintain a household such as mine. However, make your proposal and I will say whether I will accept it or not."

His own plan was, that his brother continue the house at Le Cap, establish another at the Môle St. Nicholas under the name of Girard frères \& $\mathrm{Cie}$. and have two or three brigs constantly plying between Philadelphia, the Môle, and Le Cap. He would found a third house and procure so much business that they would soon become important. To establish the three houses would require nearly four hundred thousand livres net, without counting negroes, furniture, houses and what not. Moreover the firm at Le Cap must be "shrewd, steady, honest and above all industrious." Should the proposition be agreed to, and his presence be necessary to confirm the arrangement he would, for pleasure and health, make the voyage to San Domingo during the summer.

Jean replied, "No house at the Môle! The stay I made there when awaiting your brig convinced me it will never be anything but a miserable hole." He "would rather go to live on the banks of the river Hayo than in that place." 


\section{THE LIFE AND TIMES OF STEPHEN GIRARD}

His partnership with Hourquebie would end on the first of July 1785 , and on that day, if ever, the proposed new one should begin. The capital was to consist of real estate, furniture and all assets (cash as well as merchandise), to the value of three hundred and odd thousand livres. The firm name was to be S. \& J. Girard frères. Expenses of the house, including clothing, of the office, and of all transactions and voyages to be shared, profits as well as losses, for a term of five years. Should the partnership with Hourquebie be continued, Jean Girard would send 66,000 livres. Should he not renew the partnership he would establish at Le Cap, the house of J. \& S. Girard, and keep his capital there. All rents from real estate owned by Stephen Girard should go into the capital as well as half the rent of a coffee plantation Jean was about to lease, and which ought to yield 10,000 livres net, a year. "Having considered your plan for a partnership, I believe it fair enough" was the reply, "and you may depend, at least, on our transacting some business together."

The brig reached Philadelphia early in August and in the course of three weeks was ready for sea on a second voyage to Le Cap.

Her cargo was composed of boards, hewn lumber, shingles, apples, onions and eight hundred barrels of superfine flour costing seven piastre gourdes the barrel. Because of the flour on board and the exclusion of American ships Welsh was ordered, should it happen during the voyage or when entering port, that anybody asked him "in French, the contents of your cargo, desire Mr. Dulith" to say lumber. If asked whence he came and who owned the brig, the answer must be from Philadelphia, and owned by Messrs. J. Girard and Hourquebie, merchants of Cap Français. On no account should the 
crew be allowed to say a word "about the contents of your cargo."

Of the return cargo one-third was to be raw sugar, coarse grained and pale yellow in color; one-third coffee in barrels, and the remainder in cocoa. On no account any tafia. Necessity required that the ownership of the brig "should appear to be changed." Therefore Jean was "to apply to some good friend for permission to use his name." The acknowledgment must be written in French, "and the invoice of the cargo on a separate sheet showing it to be for the account of the owners of the said boat. The duties increase every day and we are obliged to deposit our invoices and bill of lading at the custom house."

The necessity for this change of ownership came from a little trouble with the Pennsylvania customs authorities. The Federal Constitution did not then exist. The Articles of Confederation were still in force and under them Congress had no power to lay taxes, duties, imposts or excises. Each state maintained its own custom houses, and imposed on imports and exports such duties as it saw fit. Under the Pennsylvania law the entire cargo of Les Deux Frères should have been declared at the custom house; but, as the importation of flour into Le Cap was forbidden, its export from Pennsylvania was not declared by Girard. When therefore, on August 29th, Captain Welsh boarded the brig at Chester he found it in possession of a custom house officer. The Captain "threatened him" and tried all means in his "power to get rid of him"; but finding he could not, unless force was used, "thought proper to heave up and get out of the State," which he did and dropped anchor "below Neuman's Creek." "I think," he wrote from Marcus Hook, "you had better get a lawyer's opinion on the matter. If you think 
proper to bribe him, I think it can be done provided that will clear the vessel. I shall await your answer at Moulds' Tavern in Marcus Hook. The brig is detained for information being lodged of her having flour on board." Scarcely had the letter from the captain been received when a warning came from the collector. $\mathrm{He}$ was informed, he wrote, that the officers on board the brig had "discovered an intention to carry the flour off, notwithstanding the seizure that had been made of it by the naval officer" of the State. Should any resistance be made to the removal of the flour from the vessel, or should it be carried away, the owners would be held amenable to the State, and to the informer, for the value of the flour and all damages.

The informer was a man named Phile. "This fool named Phile," wrote Girard to his brother, "who has lost his place as receiver of customs, and who is no longer a naval officer, has renewed the quarrel with me concerning your business, and has taken revenge by seizing the flour which he claims was on board the brig Les Deux Frères under the pretext that it was not declared. But my zeal, added to the shrewdness of the captain with the aid of the crew, has prevented any ill effects from his evil designs." In other words, the captain took the brig down the bay and went to sea as soon as possible. A "good lawyer" having been consulted, Girard was assured "that from the moment the flour disappeared they could not touch the brig nor her cargo, but as it is necessary to take every precaution you must make it appear that your M. Hourquebie \& Co. are the owners of the cargo and the boat. That will be sufficient."

The proceeds of the cargo amounted to 69,1 6 livres, about $\$ \mathbf{1 2 , 7 9 9}$, and the cost of that sent in return 68,043 livres. Americans under the new rules might bring in 


\section{THE TWO BROTHERS}

lumber, animals, cod and other salt fish, by paying two per cent. on entering, and might take, on payment of an export duty of one per cent., such products of the island as syrup, taffia, rum and all kinds of goods that had come from France; but the export of sugar and coffee and the import of flour were absolutely forbidden. No other ship, Jean assured him, would bring to Philadelphia either coffee or sugar, nor would Les Deux Frères had not the clerk of the Admiralty given warning which enabled her to get out in time to avoid the search made of all ships going north. The taxes could not be avoided in future, for a new inspector had been appointed and a King's boat lay outside to examine all vessels departing. Should Les Deux Frères be sent back, it would be wise to despatch her to Charleston for rice. The French flag could not be used unless one-third of the crew and the captain were Frenchmen.

Though the profits of the San Domingo voyages were far from small, they were not as large as Girard thought they should be. In a letter, now lost, he seems to have said so, and received from his brother a characteristic reply.

"I have just received your letter of the 3oth of October. It is amusing to have you ask me how you can make more money. You will always be the same-never content. I dare say you will not be satisfied with the last voyage of your brig which will certainly bring a profit of at least 55,000 livres, (about $\$ 10,325$ ). The risk which we run in this trade, the trouble which it gives, added to the losses when one tries to get rid of it, is worth at least I 5 per cent. commission when working with an honest man. Therefore, as I am not as ambitious as you are, and if the manner in which we have treated you is not satisfactory, rather than work for nothing, address yourself to whom you please-we will always remain friends." 


\section{THE LIFE AND TIMES OF STEPHEN GIRARD}

To this outburst of anger Girard made no reply; but Les Deux Frères did not return to Le Cap. By an arrêt of the Council of State, dated August 3oth, 1784, American vessels, not over sixty tons burden, might bring to the French West Indies, lumber, coals, livestock, salted beef, salt fish, rice, maize, pulse, raw and tanned hides, furs, rosin, and pitch, and take away taffia, rum, and any kind of dry goods made in the factories of France. Les Deux Frères was over sixty tons burden, and must go under the French flag or cease to trade. Girard and Hourquebie, moreover, were not prompt in the settlement of accounts. Girard determined therefore to send no more consignments till the firm at Le Cap had made an itemized statement, and Les Deux Frères was made ready for a voyage to France with tobacco.

To obtain tobacco a firm in Petersburg, Virginia, was commissioned to purchase one hundred and fifty hogsheads. His experience with his Bordeaux creditors seems to have taught him prudence, for never again to the end of his life did he buy goods on credit.

To pay for the cargo of Les Deux Frères, and that no time should be lost in procuring it, shipments of specie were made before the brig returned from Le Cap. With the first, amounting to $£ 452.8 s .6 \mathrm{~d}$ or about $\$$ I 200 , went an assurance that $\$ 3000$ would follow; but just when was.hard to say as money was very expensive and the bank compelled him to take every sort of gold. He was afraid therefore that most of the coins sent would be too light, but he hoped nevertheless they would pass. With the next shipment, $£_{\text {ropg.ros in }}$ gold, went a request for the price of pig iron, old cannons or bullets fit for ballast should the brig be forced to go in ballast. The third shipment consisted of 232 guineas, worth thirtyfive shillings each, Pennsylvania money; 16 half guineas and 38 half joes worth sixty shillings each. 


\section{THE TWO BROTHERS}

The brig did not go in ballast but set sail in December with ten tons of bar iron, hogsheads of molasses, barrels of coffee and sugar, and some chocolate, pepper and soap.

A voyage of sixteen days from Cape Henlopen brought the Captain to Broadway on the James River where the cargo was to be put aboard. But none was ready. No tobacco could be obtained because the inspectors had left town. A week passed and not a hogshead came. "Sir," wrote the captain, "this is a dam'd place for doing business." Seventy-two hogshead had been shipped but the boats were all aground between Petersburg and Broadway. "I have not got a single hogshead of tobacco on board yet," the captain complained at the end of ten days, "it is the case of every ship here, thirty sail of shipping lying here. I have not seen but Two Craft of Tobacco come from Petersburg since my arrival here."

"I hope Sir you consider the Brig is not in Philadelphia where everything comes along without any delay. This is the worst place for dispatch I ever was in." At the end of a fortnight the cargo began to arrive, and late in January 1785 the brig went down to Hampton Roads and was wind bound for a week before putting to sea. Captain Harr's new instructions bade him proceed with all possible despatch to the port of Marseilles and deliver the cargo to Messrs. Samatan frères. During the voyage, and particularly in the Mediterranean Sea, should he meet with any "Algerian or Maroquer Cruiser" he was to tell them that the brig belonged to Messrs. Hourquebie \& Co., of Cap Français. The stay in port should not exceed three weeks. If the French "comissaire" at Marseilles insisted on putting two or three French seamen and a French captain on board, he must receive them; but the brig must be navigated and commanded 


\section{THE LIFE AND TIMES OF STEPHEN GIRARD}

by himself. Should he be satisfied with the English sailors replaced by French, they were not to be discharged, but entered in the French articles as passengers. Towards the end of January a rumor of war between Holland and the Emperor of Germany, and fear that France might be drawn in, caused Girard so much anxiety that the American passport of the brig was forwarded to Messrs. Samatan frères to be given to Captain Harr on his arrival. "Should the French be Engaged in that Dispute or likely to have war, take a french passport to protect you from the Algerians or Maroquer Cruiser \& after you think yourself out of danger of them conceal, in a very Private place of your vessel known by you only, all your french Papers \& come back to Philadelphia with your American register. Should you think more safe to throw your french Papers over Board I leave that to your option.*** But if it is not Like for a french war, Leave your American Register to the Care of Messrs. Samatan frères with Directions to forward the Same to me by one other opportunity."

Of the tobacco one hundred and fifty-one hogsheads belonged to Girard; fifty-three to Daniel Tyson and Richard Vaux, and forty of tobacco and fourteen casks of white Havana sugar to Mr. Charles Homassel who went as passenger. On these the freight was fifty-five livres tournois per hogshead.

Bad weather and a stay of eighteen days in the strait, caused by strong Levant winds, so delayed the brig that fifty-one days passed before she arrived at Marseilles early in April. May tenth she set sail for Cap Français by way of Philadelphia, in command of a French captain, Jean Carbonél, as required by the Admiralty Bureau, and late in July was back in Philadelphia, with a cargo costing 69,568 livres tournois.

While Girard was anxiously waiting for news of the 


\section{THE TWO BROTHERS}

arrival of Les Deux Frères at Marseilles, his wife, who had long been ailing, became insane. The blow was a heavy one and when writing to Jean congratulating him on recovery from an illness, he said: "As for myself I have not the same good fortune, for without any illness of the body, I have that of the mind. I fear that I have lost forever the peace which a certain success should procure for life in this world. In short I cannot talk of this." A little later he urges his brother to put off a proposed visit to Philadelphia. "Since my last letter of the 12 th instant (12th of May 1785) Madame continues in the same state as at that date; but fortunately for me I can accept this uncomfortable life and flatter myself that I shall be philosophical enough to overcome all these difficulties which have made me fear that something more sad might follow. Consequently I beg you to postpone your voyage to Philadelphia unless it will be an advantage to your business, in which case I shall be very glad to see you." On the first of June he wrote, "Madame continues always in the same state. I fear that this malady will never be cured as long as she lives. We can only have patience and realize that no one can live in this world without having some troubles." Hoping that a sea voyage might be beneficial he now sought to persuade his wife to go in Les Deux Frères to Cap Français; but soon changed his mind and "having thought of the care and anxiety she might create have decided to keep her here." Mrs. Girard was then in the country twenty-seven miles from Philadelphia and improved in health; but ere the year ended Girard was forced to put his wife "under restraint. I cannot tell you the anxiety and mortification which this measure and the events which made it necessary have given me. But I assure you nothing in the world could affect me more sensibly."

Vol. I-5 
To the proposal to send Mrs. Girard to Le Cap, Jean replied that, despite "the care she will be to me, I shall not be sorry to have her, particularly as my attentions \&c may help to cure her, for I am deeply attached to her. But on the other hand if this voyage should not prove beneficial I will feel very deeply the discomfort she may make me."

Girard is then once more urged to form a partnership and come to Le Cap and close the matter at once. His brother had 160,000 livres ready to put into the firm. If therefore, the proposition were acceptable, and he could not come, why not send a proxy to his friend Balansun to sign the agreement and forward an inventory of his property? The firm name and partnership could date from the signing of the papers or any other time. Enclosed was "a letter from our father with a list of your debts. See what you think of it and let me know."

The letter from the father bore date July 29th, I785, and contained a list of nine creditors. To one for beaver cloth he owed I250 livres; to another for leather 1545 ; to another for handkerchiefs 676 ; to another for cloth 1627 ; to another for millinery 1220 ; to another for hats 1285 ; to another for calico 354 ; and two others for balances of old debts 1526 and 618 livres respectively. All told they amounted to 10,403 livres, 19 sous, 7 deniers or \$1926.66. Girard made no reply and when pressed by his brother for an answer, declared that he would make no reply to his father's letter concerning the Bordeaux creditors. "If these men are, as he says, fools enough to send their power of attorney here, I will give them all the trouble possible and will not pay them for several years. And if any one persuades you to send a power of attorney against me, you may depend on my making you pay in the same way in a little while." One of the 
debts, amounting to 1220 livres, Girard, nevertheless, authorized his brother to pay, and a few months later received from Peter Stephen Duponceau, a note stating that in October 1774 the Court of the Bourse of Bordeaux had sentenced him to pay M. Laroque 1285 livres with interest, that the costs, accrued interest, and the debt amounted to more than 2000 livres tournois, that he was willing to submit the affair to arbitration or bring suit as Girard might decide. Three months later the debt was paid without interest.

Les Deux Frères which arrived late in July, was by the middle of August, ready for sea loaded with flour, lumber and bricks. Her destination was Le Cap. She was to sail under the American flag with an American passport, and in command of Captain Harr; but the French Captain, Carbonél, went along, for Girard was pledged to send him to some port in the French West Indies. Instructions to Captain Harr bade him so shape his course as to make land six or seven miles from Le Cap, and then display a short, wide, blue pennant at the foretopgallant masthead, look out for a canoe or boat and, if it brought a letter from Jean Girard, follow his instructions exactly. Should no boat come he was to push into port under easy sail and if met by any vessel of war or "guarda coast" and boarded, say he was laden with bricks, lumber and salt fish and was going in for water and to sell part of the cargo if prices were fair. No declaration was to be made at the Court of Admiralty until he had seen Jean Girard, and before going into Le Cap the crew must be cautioned not to mention that flour was on board.

During his stay he was to press the consignees to procure a return cargo quickly. If they thought proper he was to go to Turk's Island and complete the lading with salt. 


\section{THE LIFE AND TIMES OF STEPHEN GIRARD}

Jean Girard was cautioned to run no risks with the flour. If it could not be put ashore the Captain was to say that he had but touched at Le Cap and was bound for some free port where it could be landed. The return cargo was to consist of one hundred and fifty hogsheads of syrup, and of the remainder of the proceeds of the venture three-fourths were to be used to purchase coffee and one-fourth cocoa. Captain Carbonél was to be paid I30 livres tournois per month, and Captain Harr six livres for each day in port.

Returning once more to the long planned partnership Girard informed his brother that he had leased for fifteen years a lot on part of which he proposed to build a large warehouse. The remainder he should use for the preparation of outward bound cargoes, and for the reception of those just arrived.

The brick warehouse would be three stories high, sixty feet long, eighteen deep and would be started in March 1786 and finished by May. This improvement, combined with the site which he should hold for almost six years more, would give him one of the best situations for West Indian trade to be found in the city.

Les Deux Frères returned in November without Jean Girard and in command of Captain Carbonél who was to be paid for his services two hundred livres money of San Domingo, per month during the voyage, and should the brig be laid up at Philadelphia two hundred livres money of San Domingo as bounty, and a free passage to some port in the West Indies. The cheapest way to furnish such a passage was to send him back in the brig, which was accordingly done; but he returned and was still a dependent on Girard when, in April 1786, Les Deux Frères set sail for Charleston.

His first intention was to send her to St. Eustache 68 
with a cargo of flour, and thence to Le Cap with five thousand piastre gourdes in specie; lumber, and bar-iron for ballast, and a cargo worth seventy thousand pounds Pennsylvania money. From Le Cap she was to be despatched to Marseilles with West Indian produce worth at least one hundred and eighty thousand livres or $\$ 33,300$. This voyage Jean Girard was to keep secret. Not a word was to be said about it to any of his friends, nor to the Captain till he received instructions at the time of sailing. "Old Harr" had been discharged for drunkenness and neglect of duty and in his place was a young man named John Cochran. This plan, however, was soon changed and Cochran was ordered to sail for Charleston consigned to Robert Hazlehurst \& Company of that city. There the brandy, flour and hams on board were to be sold, a cargo of rice purchased and Les Deux Frères consigned to his brother. Should the Captain, when entering port, "meet any vessel of war, guarda Coast or other," and be asked what he had on board he was to reply "rice, tobacco and lumber," and that the vessel belonged to Jean Girard, merchant at Le Cap. These instructions he was to keep "carefully hid."

Les Deux Frères was to bring away 90,000 livres of raw sugar, 60,000 livres of coffee, and 30,000 livres of cocoa. After placing these prohibited articles on board with as little publicity and noise as possible, the brig was to be consigned to Messrs. Samatan frères, Marseilles. The Captain was to know nothing of this till he opened his instructions at sea. In them he was to be ordered to shape his course for the Delaware, drop anchor off Wilmington, and in his gig come to Philadelphia by night and notify Girard of his arrival. The bearer of the passport, once the ship was out of sight of land, was to draw up and have the officers sign a paper setting forth that, 


\section{THE LIFE AND TIMES OF STEPHEN GIRARD}

in the latitude of the Bermudas a squall carried away the topmast, that the brig leaked badly, and that at the request of the officers and crew he changed his course for Philadelphia that his vessel might be repaired.

Late in April the brig set sail and nothing was heard from her till one day in May Girard read in the Pennsylvania Packet and Daily Advertiser of her arrival at Charleston, of the death of Carbonél and the arrest of Captain Cochran and the crew on suspicion of murder.

"CHARLESTON, May I0.-The brig Two-Brothers which arrived here two days ago from Philadelphia, entered the port with her colors lowered. The crew reported that a French Captain threw himself into the sea a few days before they made the land, and the deceased wrote a letter in French two days before to the French Consul. This being delivered was found to contain the opinion that he stood in the greatest danger of being either strangled or drowned; conjuring him in the most earnest manner to do him justice in case he was missing, and that some money which lay in his trunk might be taken care of and remitted to France for his daughters' use. In consequence of this information the captain and sailors were committed to prison until the matter is thoroughly investigated. The original destination of the brig was that she should call here and then proceed to one of the French West India Islands, and for this purpose was provided with a French and American captain and two sets of papers."

No sooner did Girard read the account than he wrote Robert Hazlehurst \& Co. explaining how Carbonél came to be on board the brig. "When that Vessel went to Marseilles his was under French Papers commanded and navigated by American Seamen until he did arrive in the afforesaid Port of Marseilles when the French Commis- 


\section{THE TWO BROTHERS}

saire thought proper to put on Board the deceased Capt. Carbonél as porteur of Passport. This was in the month of May, 1785, and ever since the owner of the said vessel has continued the deceased by a principal of charity only. Capt. Carbonél was near sixty years of age and had the character of a Drunken, Mad and Very Malitious Man. After these circumstances I Presume the Deceased has wrote his Letter directed to the Consul of Charleston in one of his Malicious moments and in a Drunken Fit he had the Misfortune either to throw himself into the Sea or fall over Board." All this was set forth in two depositions taken before the French Consul Barbé de Marbois, and sent to Hazlehurst \& Co. for use if necessary.

They were not needed. The facts as told by Hazlehurst \& Co. were, that the French Captain for several days previous to his death acted as would a man out of his mind, and while in this condition went to the forward part of the vessel and, leaving his shoes in the main chains, jumped into the sea. The body never sank and the crew "picked him up with his clothes over his head."

As customary, Captain Cochran took possession of his chest and looking over the papers in his stateroom found an unsealed letter addressed to the French Consul. The letter was written in French and as Cochran could not read it, he showed it to Hazlehurst \& Co. They found a gentleman to translate it and were amazed to learn that the writer asserted that people on the brig daily threatened to strangle or drown him before she made port, that he begged the Consul to see justice done him, and send to his sister in France the money in his chest.

Declaring that neither he nor his crew had anything to fear, Cochran took the letter to the Consul, who 
promptly had the Captain, the mate and the six seamen arrested and jailed on charge of suspicion of murder. The trial in the Admiralty Court of the State of South Carolina was held the next day. All were honorably acquitted by Judge Drayton, "without," wrote Captain Cochran, "the people being axed a Singel question which the Judge of Admiralty told me the one that ordered me to Gaile ought to Be Committed theire him Selfe for So dowing."

A month passed and June seventh came before the brig crossed the bar on her way to Le Cap. Ere she reached there, Jean Girard wrote a fault-finding letter to his brother. "Would to God, since you have sent the vessel to Charleston, you had ordered a barrel of flour to be placed in each hogshead of rice, without the knowledge of the crew or the rest of the ship's company, as I told you to do at the time. It would have added greatly to the profits of this voyage. Superfine flour could be sold for ten gourdes cash, while rice in large lots is worth not more than 30 livres to $3 \mathrm{I}$ livres 10 . It is being shipped from all directions."

Of sugar, he need not expect to get much by return of the brig. Coffee would be sent if it were possible "to get any of it outside with any degree of security. Owing to the Sieur Marbois' hatred of Americans, the difficulties are becoming so great that we shall soon have to give up the trade altogether and before long you will probably hear of a seizure having been made. To carry on this traffic we need daring captains and it must be managed in the manner I spoke to you about, that is, secretly as if for Europe. But we will talk about this before long. I am determined to go to Philadelphia on this voyage to see you and come to a definite understanding with you one way or the other." He could not stay long: he must 


\section{THE TWO BROTHERS}

be back before winter to put his business on as secure a footing as possibie.

This business was transacted by the firm of Girard, Bonnardet \& Lacrampe which Jean had established in March of $\mathbf{1} 786$. Into it he put 80,000 livres and proposed to put a like sum into the partnership with his brother.

When at last Les Deux Frères reached Le Cap it was "with deep disgust" that Jean gave notice of her arrival. His brother's interests would have been better served had she gone down and the underwriters paid for her. The rice was inferior and while dear at Charleston was so cheap at Le Cap that he would be lucky to get off with a loss of ten per cent. What was worse, as the crew were Americans, the Commander of the port had all arrested because of the Carbonél affair. The Judge of the Admiralty and the Bureau of Enrollment found everything in order: nevertheless he must bring suit to prevent the sale of the brig. The most he could obtain was leave to unload her; but the cargo could not be sold till the case was settled. The court had appointed an inspector to take note of the goods; but he hoped to smuggle in the pork and other forbidden articles. The case was settled, the ship restored and, commanded by Jean Girard, came back safely to Philadelphia where the firm of Stephen \& John Girard was finally established.

The Court, it is quite likely ordered the brig sold, and Jean Girard bought her, for among the manuscripts is the bill of sale:

"Jean Girard of Cap François, now in Philadelphia, for the sum of £2000 Pennsylvania Currency sells to Stephen Girard the brig Kitty (formerly Les deux frères) September 29 1786."

The Kitty with Jean Girard on board was soon sent back to Le Cap, stopping at Charleston on the way. 
The voyage from Charleston, he wrote, took ten days though it should have been made in seven, "because, at noon on the sixth day out, we were some distance north of Turk's Island; but the Captain, thinking we were east of it, stood out for the southwest, and about three o'clock saw land which he imagined was Turk's Island, but not being certain, he again changed his course and, in short, amused himself by these manœuvres till night came on and then decided to lay to when I was hoping to get on shore for business reasons. After waiting till noon, I called the Captain's attention to the two bottelers and the three mountain peaks of the Grand Caymite. We did not get under way till three o'clock that night, having stuck in the mud with the wind against us. The lumber stowed on deck is much worn, but the rice in the cabin suffered most. The weight burst the barrels and the contents was scattered everywhere, even as far as my bed, wasting a great deal. After this experience I will never again permit any of the cargo to be stowed in the cabin, only the sails, some provisions, and a passenger in order to clear expenses-but not any of the cargo."

* * * "I hope that the brig will sail for Charleston on the 2 nd or 4 th of next month (January 1787 ), with a cargo costing from 70,000 to 75,000 livres (about $\$ \mathbf{1} 3,900$ ). If this venture is a success it will yield a fine profit. It will bring back seven hundred hogsheads of rice, now at a low price, and Hazlehurst will send you from $£_{11,000}$ to £r2,000 sterling, over and above the rice, and it will not include the balance now in his hands, but will be simply the proceeds of the cargo sent."

No such profits came from the voyage. When the Kitty set sail much of her cargo was to be delivered to her at sea, for neither the coffee nor the sugar could be lawfully exported. "However" Jean explained, "I got 
the coaster that was waiting for the twenty-four hogsheads of sugar for the brig outside, and he had not been gone three hours when there came into these waters three gun-boats, which I presume had been despatched for this very purpose. They have had three days of good weather to make the transfer, and I feel sure that the Kitty must have sailed on the IIth or I2th. I have secured sixty thousand of coffee from three different plantations and have supplied new sacks to put it in as there is a coaster in the place where the coffee comes from who can despatch his vessel without arousing suspicion and can put in here in case of accident. If the coffee were put up in barrels, which would be more expensive, the danger would be much greater. Besides, you can fill these sacks, secretly, with flour and put them in hogsheads of rice, for. flour will remain at a high figure for some time."

The coaster sent to get the sugar was delayed, and the Kitty went off without it. As the schooner which took out the coffee entered the harbor on her return, a gun boat, coming to inspect her, hove in sight, and the captain threw overboard all letters and bills of lading, "as without that precaution he would have been seized and suffered the penalty provided by law." No documents, therefore, existed to prove that the captain had transferred his cargo to the Kitty. Nevertheless, Girard, Bonnardet \& Lacrampe, had no doubt the insurance would stand.

When he heard from Hazlehurst \& Co. that sugar was selling at auction in Charleston at eleven pence a pound, molasses at thirteen, and coffee at thirty-five shillings per hundredweight, he sent a copy of the letter to his brother, with the remark:

"The contents will inform you that if you had fol- 


\section{THE LIFE AND TIMES OF STEPHEN GIRARD}

lowed the plan, and held to the destination we agreed upon, you would not have been caught. It seems to me that it is as easy to agree about expeditions as about shipments. If harmony is to reign, one of the partners must not be of a domineering disposition, and must not refuse to send the articles that the other partner, who is on the spot where they are to be sold, has requested. I am very much annoyed not to receive the cargo $I$ ordered from you in my letters of the 2 Ist and 23 rd of November. At the present moment, molasses is worth from two shillings to two and six pence in cargo lots, and coffee from eighteen to nineteen, which would have yielded a net profit at the very outset of thirty thousand livres without counting shrinkage, insurance or loss by spilling or other costs." The loss on the cargo to Charleston was 20,000 livres, about $\$ 3,700$.

The mental strain caused by the affliction of Mrs. Girard was telling on him. For a time he thought of placing her in the Pennsylvania Hospital, and early in the year obtained from the two sitting managers the necessary certificate as to her condition: but in June she was sent to the house at Mount Holly, and Girard determined to make a sea voyage. Again and again, therefore, he urged his brother to come to Philadelphia that he might "make a voyage, for I assure you I am very tired of the daily entertainments with which my better half provides me." "I must urge you to wind up your affairs so that you can get here by the next voyage of the brig. I can then get away in August and undertake a voyage which, if it turns out a success, will bring us a good deal of business and will thus be very lucrative." When Jean wrote that certain weighty reasons would keep him at Le Cap all summer, Girard replied, "I note that for reasons you call weighty, you intend to 
break the promise you made to me to come here next Spring or in the course of next Summer. You cannot be ignorant of the strong reasons I have for wishing to $a b-$ sent myself for a few months, and that I expect to use the time in procuring lucrative business for our firm, therefore, make your arrangements so as to come back on the next trip the brig makes to take my place." In another letter he repeats the request "that you arrange your affairs in such way as to come on the brig's next voyage. I shall wait impatiently for you at that time," and closes with the words "I embrace you and beg you to come here on the brig's next voyage."

By way of preparation for the voyage, Girard now made his will, which obliged him "to pay out two portugaises for a lawyer's fee. The latter tells me that the law of Pennsylvania allows the wife, during her life time, one third of the income from the real estate left by her husband at his death, and in addition she receives absolutely one third of the personal property, or, in case there are no children, one half of the said personal property. As I wish to be just, I think, that having been so unfortunate as to marry this unfortunate woman, it is my duty to see that she is provided for to the best of my ability. I shall, therefore, leave her instead of the above mentioned rights, a life annuity which I believe will be sufficient, and, as in a case of this kind it is not well for strangers to know one's affairs, I have made you my testamentary executor." Again the brother was urged to come by the return voyage of the brig, and warned that, if he did not, the business would be left in the care of a friend, for Girard was determined to go. He had "engaged store room to the amount of $£_{175}$," had taken the house in which he lived for another year at $£_{120}$ instead of $£_{1} 60$ which he used to pay, and retained the 
clerk at $£$ ioo a year. By the account of sale from Hazlehurst \& Co., it appeared that the cargo of the Kitty amounted to the net sum of $£_{1390,}$ I 1 s, sterling, which was "very far from tallying with the calculations" Jean had made.

To this reproach the brother replied that he did the best he could with the information at hand, and that it would be better to give up all projects of this kind and confine themselves solely to voyages from Philadelphia. The older he grew, and the more experience he gained, the more convinced he was that if their capitals were combined they could make more money in Philadelphia and live with infinitely less anxiety. He was worn out with working so hard; his strength was leaving him, and he foresaw his days passing away amid the trouble and torment of the ambition with which Stephen had inspired him. When he considered that the last voyage to Charleston, a voyage promising almost certain and enormous profits, had been so disappointing, had not even earned interest on the money, he was ready to sell the brig if Girard would consent. So discouraged was he, that if Stephen approved, he was ready to end the partnership at Le Cap and transfer all his funds to Philadelphia. This was not weakness, but firm conviction that concentrated capital produces more than money invested in many different enterprises. While in this state of mind the firm at Le Cap was dissolved and a new one, Girard \& Lacrampe, established.

Girard meantime had written to Samatan frères at Marseilles telling of his proposed voyage to that city and offering to sell them a half interest in the brig Kitty, to ply regularly between their city and Philadelphia.

"We should" was the reply, "be as much pleased as yourself to have a half interest in a French vessel to ply 
regularly between your city and ours. We should gladly be the owners; but the vessel must sail under the French flag, not the American, because two thirds at least, of the crew must be French. Let us have your views in regard to this. If it is possible to meet them we will do so." To this proposition, Jean replied there was much to be said for and against, and he would discuss it when he came to Philadelphia. "Our object is to get rid of the brig. It would be a fine stroke of business if we could succeed in bringing it about, for I have never been, and am not now, in favor of fitting out vessels. Do not let us close our eyes to the facts, my friend, but let us make an end of it now. Business is in a more than deplorable state in this port. I would give a hundred portugaises to be rid of my business engagements and be able to retire altogether."

In July, the Kitty once more set sail for Le Cap carrying a power of attorney authorizing Girard \& Lacrampe to sell her for five hundred portugaises, in order that the firm might pretend to buy, and so put her under the French flag, preparatory to the voyage to Marseilles. As Girard was "determined not to run any more risks from smuggling or other causes" the firm was requested "not to load any prohibited merchandise for the return voyage whether for your own account, or that of the cargo, or as freight. If you do, I warn you that you will have to bear the loss of any accidents that may occur, as well as the delay it will occasion to the vessel and cargo."

Jean Girard when he read these words "was astonished to such a degree" that he was beside himself "for two hours." "This express prohibition on your part forces me to sell, for the account of the Philadelphia house, a fine lot of sugar and coffee that I bought 
and had ready in advance. I thought that I was worthy of confidence as you in our special operations. You should have told me that if I had not already bought anything to confine myself to syrup. I am afraid, my friend, that the tone you adopt will never do with me. It is evidently the result of the ill success of those adventures which I have always detested, and which you persist in undertaking. I hope that we will soon give them up, so that we may live together amicably as brothers and partners." The season was then so advanced that he would stay where he was. He had no desire to expose his wife, his child and himself to the dangers of an equinoctial sea merely to please "your caprice, for there is no necessity, now that your house is quiet, for your going away from Philadelphia."

Nevertheless, the pretended sale was made, and the brig renamed Les Deux Amis and put under French colors and commanded, nominally by Stephen Girard but really by Jean Girard, left Le Cap late in September 1787. The assumption of his brother's name was necessary because Jean was not a licensed captain, and used the license Stephen had obtained years before, and which the father had forwarded from Bordeaux.

On the arrival of Les Deux Amis at Philadelphia, Girard began to prepare in earnest for the long anticipated voyage. Samatan frères were informed that the brig under command of Stephen Girard would sail for Charleston, there take on a cargo of tobacco, rice and indigo worth 75,000 livres tournois, and go thence to their port. In order that an insurance of thirty thousand livres tournois might be placed on the hull of the brig by Samatan frères, it was necessary to inform them "of the state of the vessel and, privately, of the manner in which she had been despatched." She was entirely 
new as regarded cordage, sails and rigging, was recently sheathed, and "was placed under the French flag by the firm of Girard \& Lacrampe, of Le Cap, to whom the vessel appears to belong. From that port she was sent on September 22nd last to Philadelphia under command of Mr. Girard who is not licensed. She has the Consul's leave to make a voyage to Marseilles under command of Mr. Stephen Girard who has a captain's license from Bordeaux. As the insurance companies of this city are not the most reliable, and under the pretext of war are demanding too high a premium, we think that it would be well to take the old American passport under the name of Les Deux Frères and use it cautiously in case of any enemy on the high seas, as the French passport is to be used only at Marseilles." His old friend, Daniel Tyson, was given power of attorney to act for his interests in case of the death of his brother during his absence. A certificate was then obtained from Edward Shippen setting forth that Girard had taken the oath of allegiance

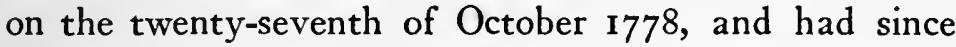
that time been a citizen and inhabitant of Pennsylvania, and another certificate signed by. Franklin as President of the Supreme Executive Council of the Commonwealth of Pennsylvania, certifying that Edward Shippen was President of the Court of Common Pleas in the County of Philadelphia.

December thirteenth, the brig was off Cape Henlopen, and a week later anchored off Charleston. There Girard spent five weeks, during which time he was made a Master Mason in the Union Blue Lodge No. 8, under the jurisdiction of the Grand Lodge of Ancient York Masons in Charleston. Early in February 1788, he was again at sea and March twenty-first reached Marseilles.

With two of the stores vacant, with prices, of such Vol. I-6 
commodities as he had for sale, low, with business dull and bad news from Le Cap, Jean Girard again grew despondent. A letter from the house at Le Cap informed him that a Mr. Martin, whom Girard had discharged, had come to Le Cap and was about to declare before a notary that Jean Girard had signed "Stephen," when he really was "Jean;" that he was not a licensed captain; that the brig had been sent from Le Cap to Marseilles to touch at Philadelphia; that she had been sent under the American flag; that she carried two passports; that he had heard that Captain Carbonél had jumped overboard because of a dispute between him and the crew; and that he had written to Marseilles to have the brig attached. All this, the Cape house believed, was to extort money and was repeated merely to keep Jean Girard posted, and warn him to have everything in proper order at Marseilles even if it cost something.

"I hear from Le Cap," Jean wrote, "that many inquiries are made about the brig which the authorities would like to seize if possible. Therefore, sell this vessel and send a release to our surities as owners and proprietors. I am not willing to run the risk of a return voyage and since you put the matter on this footing, I will say that you have not the power to run this risk on your own responsibility, because this venture concerns the partners and not you alone. If any accident should happen, it is my capital you are working with and I, therefore, insist that everything we have on board the brig Les Deux Amis shall be insured at Marseilles, and you as master of this expedition are intrusted with this duty."

When the account of sale of the cargo taken to Charleston by Girard was received, Jean wrote, it was clear, "we shall lose at least $£_{200}$ besides $£_{700}$ for the outlay. 
This is what comes of fitting vessels out for the coast, and I, therefore, entreat you to sell this cursed brig which has made money for you but is crushing me to earth. I shall always curse the unhappy moment when I became a part owner and the dupe of my ambition. This is what I propose. Sell the brig, put the proceeds at good interest, and come home as a passenger as soon as possible, rather than bring her back on our account. Running expenses, rent and wages are going on as usual; but you at least have the satisfaction of making the voyage you wished for so ardently. You are more than $£ 600$ short on your capital, consisting as it does, of merchandise and stores assessed beyond their value. You are making an allowance to your wife and we are losing money right and left. I hope you will get some good business for us back here and at Le Cap, so that we can at least keep things going. Otherwise we shall be left high and dry with no more business than we have at present. This is not the time to make money on loans with large discounts, as you have made most of your money. Unfortunately for mc the conditions are reversed. Yes, I am angry at fate and ask you to pay particular attention to what you have heard from Le Cap."

"The brig as you know belongs at Le Cap and is therefore a French vessel, insured as such, whether here or at Marseilles, as well as her cargo which, in the insurance policies, appears to belong to the owners. I say that the signing of the bill of lading and making out invoices in such a way that the vessel and cargo appear to belong to Stephen and Jean Girard contradicts all the other statements, and we are therefore uselessly paying out money for a premium and running risks of Algerian pirates who have a perfect right to seize the cargo as American and belonging to a Philadelphia house. In case 


\section{THE LIFE AND TIMES OF STEPHEN GIRARD}

of accident we run the risk of not getting our money from the French insurance company, and all this because you would not say "loaded for the account of Girard \& Lacrampe of Le Cap'."

None of these dreaded things came to pass. The voyages out and back were safely made and in July Les Deux Amis was once more at Philadelphia, where Girard was fined" five pounds for neglecting to put the brig "in the condition required by rules and regulations of the Port."

What now happened between the brothers cannot be known. That they should long remain partners was impossible. The firm of Stephen \& Jean Girard was dissolved in October, the share of Jean Girard in the brig was purchased, and in November he, with his family, went back to Le Cap.

Scarcely had Girard returned from Marseilles when by the death of his father, in April $\times 788$, he became heir to a part of the estate. On the day Pierre Girard married a second time, February 1767 , he executed a will under which Stephen Girard was to become heir to all the property acquired during the lifetime of his mother, and the children of the second wife, heirs to all property acquired during the life of their mother. An inventory attached to the marriage contract fixed the amount of Stephen's share at 50,088 livres.

Unable to attend to the settlement of the estate himself, a power of attorney was sent to Messrs. Hourquebie Brothers at Cap Français with a request that they forward it to some friend in Bordeaux who would care for his interests. But nothing more was heard of the matter till the middle of July 1789 , when a letter was received from M. Lahens of Bordeaux. It bore date, April thirteenth, and set forth that Hourquebie Brothers had sent the power of attorney to him; that from the statement 
accompanying it he saw that, as a matter of precaution a power of attorney had been forwarded to M. le curé of St. Remy, M. Batanchon who, after the father's death, had given it, together with one from Jean Girard, to M. Gaube of Bordeaux, and that his interests could not possibly be in better hands.

M. Gaube reported that on the day of the death of Pierre Girard a seal was placed on all the effects in the house he occupied in Rue Ramonet. But, because of the absence of Stephen Girard, and in the interest of the minor children, the public prosecutor proceeded to exercise his office and at his request a trustee was appointed for the children of the second marriage, Nicholas, Elizabeth, Catherine. The Trustee was a cooper, an honest but incapable man, entirely under the influence of the minor children. After the seal was placed, 24,000 francs were found in the cash box of Pierre Girard and deposited with a merchant and old friend of the family. At the request of the Trustee, all interested in the estate were summoned to assist in making an inventory of the property.

"It would be difficult," wrote M. Gaube, "to give you anidea of the disorder in which we found your father's affairs. There were no books, not even rough copy books, nothing but a mass of papers, a number of letters, docu-. ments, bills of lading, and invoices covered with dust and absolutely useless. But an inventory was made of every thing because of the presence of three attorneys, acting in the interest of the minor children." Three months were consumed in drawing up the inventory "and I am not exaggerating when $I$ assure you that $I$ was almost the only one to blow away the dust, while those who were being.paid for their work frequently staid away or rendered but indifferent aid. At last we finished the 
inventory of a lot of useless things in Rue Ramonet, and finally closed our voluminous inventory by listing fifteen to eighteen barrels of old wine which we found and which made the most important item."

The Trustee was empowered to sell the wine and deposit the money; but he divided it among the minor children, paid the notary the cost of the inventory, paid the attorneys the costs of attendance at the making of the inventory, and by such payments reduced the 24,000 livres on deposit to 13,000 .

Despite the inventory fixing the estate of Stephen at 50,088 livres, all the property M. Gaube could secure for him was $18,45^{8}$ livres short of that sum. The $13, \infty 00$ livres on deposit with the Bordeaux merchant had been replevined by the minor children. Even if he obtained a replevin, by privilege over all other creditors, the estate would not suffice to satisfy the claim of Stephen Girard. Thereupon, M. Gaube consulted some "well informed lawyers" who told him, if he presented a claim for Stephen Girard as heir, he would bring down on him all the creditors of the estate and expose him to endless litigation, that Girard should repudiate the inheritance and be satisfied to claim together with his brother and sisters only a share of the 50,000 livres. "Such being the state of affairs I am now seeking a replevin on the 13,000 livres in your name as well as in that of your brother and Mlle. Victoire who has agreed to join with me. Madame Fénélon (Marie Sophie Girard) is also seeking a replevin concurrently with ourselves, and I have no doubt we shall beat the creditors of the estate who also demand this replevin.

"As, therefore there seems to be no doubt of our being able to obtain this preference over your father's creditors, I shall have this sum to divide between your 
sisters and your brother. Please tell me what use you wish me to make of your share. You have some personal creditors in this city who are asking for their due." $M$. Gaube urged a prompt settlement of the estate, without lawsuits, as Victoire Girard was in real want.

Girard replied that he was surprised that no books were found after his father's death as he knew him to be a very exact man. Some evil disposed persons must have taken advantage of his illness to make off with the books and papers. He was much pleased with what M. Gaube had done and asked him to sue if necessary for his "maternal as well as paternal rights and dispose of the results in the following manner. You will reimburse yourself for your outlays, costs, commissions \&c., and pay for my account the following parties the sums hereinafter mentioned and nothing more, requesting them to give you the notes I made out to them with a receipt in full, to wit: to $M$. Jean Davit I250 livres, 4 sous, and 3 deniers; to $M$. Laflaverie Jr., I54I livres, 7 sous, 6 deniers; to Messrs. Herrault, Père et Fils, 676 livres Io sous, to M. Antoine DaCosta 1627 livres; to M. Charamel 654 livres, I2 sous, Io deniers; to M. Lavialle 6I 8 livres, II sous, the whole amounting to 6372 livres, five sous 7 deniers. If any funds remain you will use them for the purchase of a small house and appropriate the rent of the same to the use of my sister Victoire.

"I should be delighted to own the property at Baurech, and the house in Rue Du Loup. If, after my claims have been satisfied and my creditors paid, you should need not more than five or six thousand livres to make these purchases, let me know, so that, if I am still of the same mind, I may profit by the first opportunity to send you the necessary funds.

"My personal creditors have no right to take out an 87 


\section{THE LIFE AND TIMES OF STEPHEN GIRARD}

injunction against the funds in the hands of Messrs. Laboyde Bros. (the Bordeaux merchants with whom the 24,000 livres had been deposited). I notified them several years ago to appoint some representative to collect their claims here, or at Le Cap, and several have done so and been paid."

Concerning a charge made by the children of the second marriage that the children of the first owed money to their father, he well remembered that his late father carefully entered in a book the expenses of each of his children. As to himself he admitted that according to his father's accounts he owed him 349I livres, 5 sous, 7 deniers. He had in his possession a copy of the account and a letter in which he was told to deduct that sum from his claim after his father's death. To his knowledge Jean Girard owed his father 10,000 livres advanced for negroes, horses, and in cash. "As I desire nothing but justice and what is my due, I believe, like yourself, that our personal accounts should be charged against us in settling with the children of the second marriage, but I cannot believe that the creditors of my late father have the least right to the 51,399 livres belonging to the children of the first marriage for the following reasons. First, we ought to be favored above all creditors. Second, my late father's debts were contracted for, and during his second marriage. Then, as the debts of the children of the first marriage are to be charged to their respective claims, they can have no share in the debts contracted during the second marriage.

"As for myself, I was very young when my father married the second time, and can truly say that since that time I have paid for my support, and for a few month's schooling that I had with Messrs. Lagrasse, out of my pocket with the money I earned at sea." He was 


\section{THE TWO BROTHERS}

most anxious to secure his share of the estate his father accumulated during the first marriage, that he might give to his "sister Victoire the assistance of which she seems to stand in great need." Till the estate was settled M. Gaube was to use Girard's share of the revenues to supply the wants of Victoire.

The journey to Marseilles and Cette having satisfied Girard that a profitable trade might be built up with those ports, and that Samatan frères were merchants of standing in the world of commerce, Les Deux Amis was made ready for a second voyage. Samatan frères were then notified that the brig was going to Petersburg, Virginia, to take on a cargo for the joint account of $\mathrm{Mr}$. Daniel Tyson and Girard share and share alike. The half of the cargo, Samatan frères were to insure for 25,000 livres tournois, and put a like sum on the vessel. The captain would be his old first mate Daniel Dot, and the voyage would be from Virginia to Cette, touching at Marseilles. Because of dangers from the Algerines and others, Girard thought it would be necessary to notify the insurance companies that the majority of his crew had deserted, that he had been forced to fill their places with strangers, that while the vessel appeared to belong to Girard \& Lacrampe it really belonged to him, and that the insurance must therefore be for his account. For many reasons it was important that the vessel should appear to have changed owners, and feeling sure that Samatan frères would oblige him in this matter the necessary papers were sent to enable them to put the vessel in their name. His brother's share had been purchased for four thousand piastre gourdes or 23,000 livres tournois. Should Samatan frères wish to buy a half interest at that price, or less, he would be much pleased, both because of the advantage of such a connection and be- 
cause he should then have less money risked on one ship. Quite probably the commissionnaire at Marseilles would refuse to pass on the roll of the ship's company the names of the mate, four sailors and his negro. They were English, from Acadia, or Americans. Should it be necessary to replace them with Frenchmen before the return of the brig, the discharged sailors were to remain as passengers after making it clear to them that no wages would be paid till they were back in Philadelphia.

Captain Dot was to keep, in a secret place, his letters and any other papers which might give rise to suspicion should he meet "Algerian pirates," be sure not to sail out of the James River unless the weather was settled, employ one of the best pilots, see that the masts were solid, brace his mainstay to the foremast, report by every mail all that happened to vessel, crew and cargo, and not forget to bring home some canaries.

Four weeks were spent in securing and stowing the cargo, and the middle of December came ere the brig sailed for Marseilles.

Now that Les Deux Amis was to be used for trade with Marseilles he began a search for a vessel of from eighty to one hundred tons to trade with San Domingo. He found one named the Polly, bought her for $£_{700}$ Pennsylvania currency, and wrote his brother, "I have decided to buy a charming little brigantine and a very good sailor, which I am going to send you under the command of Captain Edger. Her cargo will consist principally of rice with three or four hundred barrels of flour. The vessel has a hermaphrodite rig, and the figure of a woman is the figure head. The sides are covered with fretwork and the color is about the same as that of Les Deux Amis. I have ordered the captain to announce himself, when he draws near Le Cap, at about five or 
six leagues from shore, by attaching a small broad blue pennant to the fore-top mast, and bringing the yard of the fore-topmast back against the stay with the top sail merely clued up. If the wind is very strong the sail will be furled. As regards this venture, I am entering on it in the firm conviction that the ports of the French Islands will be open to Americans for the introduction of flour. If this is the case send the vessel back to me at once in ballast and five or six thousand piastres."

The return cargo was to be syrup, sugar, coffee, cocoa; but should there be any delay in getting these articles, the Polly was to come back at once in ballast, for, if the ports were open to flour not a minute should be wasted. The vessel had been purchased for trade with Le Cap and if this proved lucrative he would buy another. As for Les Deux Amis she was to remain in the Marseilles trade. So many vessels had sailed for San Domingo with flour, rice and lard, and so many were going under the belief that the ports were open, that flour had risen to forty shillings a barrel and wheat to seven shillings six pence a bushel.

Instructions to Captain Edger bade him, if, when he reached Le Cap, he met a "guarda coast or others" and were asked of what the cargo consisted say, "flour, rice, lard, and that you are bound for St. Thomas, but having had the misfortune of falling to the lower of your port, together with your vessel being dip loaded you did propose to sell your rice at Cap Français in view to lighten your said vessel and to enable you to reach the port of your destination."

A passage of eighteen days brought the Polly to Le Cap where the Captain, to his surprise, found the port open to flour and readily sold what he had on board at from seven to ten dollars a barrel, and the rice at from three 
and a half to four dollars per hundredweight. At forty shillings Pennsylvania money a barrel the cost of the flour was five dollars and thirty-ninetieth a barrel and the rice two dollars and sixty-ninetieth a quintal. "It is unfortunate," Jean Girard wrote, "that your brig arrived three days late as that made a difference in the sales of from eight to ten thousand livres. I send you a decree by virtue of which the ports in the southern part of the island are declared free and neutral. This added to the difficulty of getting goods outside, will cause a revolution in the prices of commodities. At the present moment everything is high, especially sugar, and that has decided me to send you specie." The amount sent was forty thousand livres. Early in June the General extended the time during which flour might be imported, to the first of October, and allowed the exportation from Le Cap of coffee, sugar, cotton, and cocoa on the payment of duties.

By that time Girard had heard of the arrival of Les Deux Amis at Marseilles. Samatan frères were sorry to find so much tobacco in the cargo. Wheat would have been much more profitable. At six shillings six pence a bushel in Philadelphia a charge would have cost but twenty livres in that city, and with six livres a charge for haulage and expenses, there would have been, with wheat selling at thirty-nine livres and a government bounty of three livres, a splendid profit. The seventy-five barrels of flour would therefore be very profitable. But the two hundred and twenty hogsheads of tobacco could not be sent to Cette and would have to be stored for three reasons. First, to get out the flour much of the tobacco would have to be unloaded. In the second place in order to sell the vessel, under the power of attorney, she would have to be empty, or some ulterior motive would be sus- 
pected as the reason for the sale. In the third place tobacco was selling so poorly that a memoir had been addressed to the Contrôleur Général requesting him to compel the Fermiers Généraux to buy tobacco in accordance with obligation to purchase 4000 hogsheads in the ports of France every three months. The brig should be sold, Samatan Frères becoming the purchasers, and to oblige Mr. Girard they would perhaps keep one quarter interest. The tobacco was accordingly landed, the sale made, Les Deux Amis renamed La Virginie and Captain Dot ordered to take her in ballast to Cette. But the day he was ready to sail, the sixteenth of March, "the people of Marseilles took it into their heads to get up a riot for the purpose of bringing down the price of bread and meat. This obliged the magistrates to close the gates of the city and prevented me from leaving. I remained four or five days waiting for the excitement to calm down and then departed on the twentieth." Adverse winds forced the vessel back into port and April came before Cette was reached. There La Virginie was loaded with brandy and white malvoisie and dispatched to Philadelphia. "I shall only tell you," wrote Captain Dot from Cette, "that three fourths of the cities in France are in revolt for the purpose of lessening the prices of bread and meat, so that wheat and flour will always have a good sale although the harvest promises very well." At Marseilles the Captain had shipped a Provençal crew and second officer. But "they happened to be on shore on the day of the riot and, as did the sailors from all other vessels, they went on a spree and when I reproved them two deserted and the other three requested the Commissionnaire to give them their discharge on condition that they return their advance wages," which was done and their places filled by the first comers. 


\section{CHAPTER III}

\section{A SPECULATION IN WHEAT}

To those engaged in trade and commerce with foreign countries or between the States, to those engaged in business of any sort at home or abroad, the fourth of March, 1789, marked the beginning of a new era of commercial and industrial prosperity. The old confederation had been swept away. The Constitution, framed at Philadelphia in 1787, had gone into effect as to the eleven ratifying States; the first Congress under that instrument of government had assembled at New York; and in that city on the twenty ninth of April the first President of the United States took the oath of office.

Henceforth no State, without consent of Congress, could lay duties on imports or exports nor ever again issue a bill of credit, nor make anything but gold and silver coin a legal tender for the payment of debt.

Henceforth no vessel engaged in foreign or coastwise commerce could ever again be required to enter, clear or pay duties at any Custom House save one established by the United States. Congress now had sole power to regulate trade with foreign nations and among the States, and all State navigation acts, tariff acts, all State laws imposing duties on ships, on imports, on exports, or establishing Custom Houses for their collection must be repealed.

This liberation of trade and commerce from the restraint imposed by the States was a great step forward, but scarcely had the new government under the Constitution been established when the French Revolution opened and for years to come the foreign trade and com- 
merce of our country was hampered, injured, and well nigh ruined by French decrees and British orders in council.

With the causes of that revolution we need not be concerned. It is enough to know that after a period of 175 years the Estates General met at Versailles on the fifth of May, 1789. As of old it was composed of equal numbers of delegates from the Clergy, the Nobility and the Third Estate, another name for the common people. These deputies in ancient times did not sit together, nor vote together, nor were they to consider the interests of the French monarchy, but the particular interests of the several classes to which they belonged. But the French people in 1789 were very different from the people of France in 1644, when the Estates General had last assembled. The deputies of the Third Estate now refused to sit apart, invited the deputies of the Clergy and Nobility to sit with them and pass on the affairs of the nation, and when these deputies would not, those from the Third Estate declared themselves the National Assembly and on the 17 th of June organized the first modern representative assembly that had ever gathered on the continent of Europe.

While the assembly labored hard to introduce reform after reform the people in parts of France suffered the pangs of hunger. The crops had failed, there was a shortage of wheat and a rise in the price of bread. Every letter from Samatan frères urged Girard to buy wheat and nothing but wheat. In February they wrote from Marseilles "it is worth 40 livres per charge (four and a half bushels) which is a famine price, and besides the government grants a premium to anyone receiving wheat from abroad from now to the 5 th of June. This premium amounts to 3 livres per charge, the condition being a 


\section{THE LIFE AND TIMES OF STEPHEN GIRARD}

certificate from the French consul that the wheat has been loaded in such and such a foreign port." Wheat was selling at Philadelphia for 6 shillings 6 pence a bushel "which would make the cost of a charge only 17 or 20 livres in your city which, with 6 livres for haulage and expenses, offers a superb profit when wheat can be sold here for 39 livres besides a premium of 3 livres from the government."

So tempting was the speculation that in February Samatan Frères bade their correspondents, in Cadiz, charter a French vessel of 150 to 250 tons and send it to Philadelphia to take on a cargo in that "or in some neighboring port," and wrote Girard. She would bring "the necessary piastres fortes to carry out this operation and you will kindly purchase the cargo as quickly as possible, for, if the vessel gets back to Toulon in May or June we shall have the benefit of the premium of 3 livres per charge."

Though every effort was made to procure a ship quickly, it was April when the brigantine Le Héron of St. Malo sailed from Cadiz with 8,000 piastres fortes, and August when she reached Marseilles loaded with wheat. In reporting her arrival Samatan Frères remarked that the tobacco brought by Les Deux Frères was still unsold and gave the reason.

"Our revolution being over and the people having the upper hand, the National Assembly, composed of twelve hundred representatives of the nation, is at work on a new Constitution in which the King's rights will be reduced to his deserts and nothing more. Liberty having thus won the victory, the Fermiers-Généreaux are in doubt, and do not know whether they will be retained or dismissed. In the latter case the tobacco trade will be 
free and that article will become current merchandise. Until that has been decided the fermiers do not dare to load themselves with tobacco. For the present we do not think of the articles however low the price may be. Give all your attention to flour and wheat."

So great was the profit of this venture that Samatan Frères sent back Le Héron and two other vessels, ordered fifty thousand bushels of wheat for their own account, and suggested that Girard take a half interest in fifty thousand more, over and above the cargo of the three ships.

Meantime Girard, quite as eager to take advantage of the fine markets for wheat and flour at Marseilles and Le Cap, thought of building, or buying, a brig of a thousand barrels capacity, to sail with the Polly between Philadelphia and St. Domingo; made shipments of flour to Le Cap by the Polly, the Exuma and the Bernardo and sent La Virginie to Marseilles with wheat. The Exuma arrived with her cargo worth I0,404 livres, I4 sous, 6 deniers but Jean Girard warned his brother that, because of the great quantity imported, all the ports save the southern would be closed to flour on the first of October unless the present Intendant was recalled. "In France all things are topsy-turvy. Civil war is approaching. De la Luzerne has surprised us by sending here a General. This will hasten his downfall as well as Marbois'. You see by the enclosed newspapers that I was right in my expectation that flour would not be admitted after the first of October, unless shipped by permission. This is Marbois' style." "We are not getting any flour from Europe, but nobody would have supposed that the Americans could furnish so much through New York, Philadelphia, Wilmington, Baltimore, Alexandria, Norfolk and all the other places that do not even produce any. 
But all this would not do so much harm as the fact that we have ten or twelve commission merchants, all engaged in this business, and that you are all possessed with a rage to sail away two or three days after your arrival. The price of French flour to-day is Ioo to I ro livres a barrel, and why? Because the Bordelaise captains do not have to sail away the next day, and the flour left in the hands of our firms maintains its price. I know very well that it would be useless to try to get American captains and owners to stay here any length of time as they always fit out their ships with their sixty day notes. France has been within two finger breadths of destruction; but the Third Estate has the upper hand and we are going to be the happiest people in the world. The King will be reduced to his bare rights, which will be enormously curtailed, and the nobles will have no more exclusive or unjust privileges. However the end is not yet. Our Intendant is to be recalled. It is said he has already been exiled. One thing is certain; this is a unique revolution."

Bad news now came from Marseilles and Le Cap. La Virginie had arrived at Marseilles and would sail with a cargo of brandy insured for forty-five thousand livres; but trade was greatly embarrassed by the scarcity of specie in all commercial centres. "It is estimated," wrote M. Samatan, the old firm having dissolved, "that during the extraordinary revolution that has taken place in our monarchy, about two hundred thousand emigrants left the country and carried away with them a great deal of specie, and the capitalists who have stayed in the country are hiding their money, so that trade in the interior of France is very much embarrassed."

Trade conditions at Le Cap were quite as bad as at Marseilles. The Colony was on the verge of revolution. 
The people were clamoring for local self government with representation in the National Assembly. The negroes were growing restive and money was becoming scarcer day by day. As Jean Girard wrote, "We are in the midst of a terrible crisis, contre-coup of the European revolution. The young people are greatly excited, and gather in public places and at the theatres. One man, who held the same opinions as Marbois, was made to ride upon an ass. Search is being made by land and sea for Marbois, for it is said that he fled from the colony with two million five hundred thousand livres. If he is caught nothing can save him from the gallows, so far has feeling gone. I sigh and suffer greatly for all this disorder. The government owes me money both for your flour, Cochran's and Messrs. Petit's, about thirty thousand livres, which has caused me in the past, and still causes me, a great deal of anxiety, chiefly because of the delay, as I do not think I shall suffer any loss. God grant that this disturbance may come to an end, for there is some fear that the negroes may revolt. Because of all this, we have, since yesterday, in addition to troops, one hundred militiamen who patrol the city every night." A postscript added that "the local Committee has succeeded in quieting the negro element somewhat, and it has been decided to merely send fifteen deputies to Port-au-Prince to make M. de Marbois render an account." "We are without any law or government whatever, for the present, and are constantly armed to protect ourselves against the Africans who have already revolted in various places. Several of these were executed yesterday evening."

Acting on the suggestion of the old firm of Samatan Frères, that Girard should take a half interest with them in shipments of wheat to not more than fifty thousand bushels, he now, with Daniel Tyson as partner, chartered 
the English ship Ann and sent her to Petersburg, Virginia, there to take on some fourteen thousand bushels. "My reason," he wrote to M. Samatan, "for chartering her on shares with Mr. Daniel Tyson is that I have the greater part of my funds tied up in merchandise and in a variety of ventures, and therefore have some doubt about my ability to procure money enough on my drafts to complete the cargo at once. Moreover, as everything is consigned to you, I thereby realize one of my chief ambitions, which is to procure you all the business I can. In compliance with your wishes I give you a half interest in my share of this cargo, which fact, you will kindly notice, for various reasons, I will not speak of to anyone, and the invoice and bill of lading you will receive from the consignor in Virginia will not contain any mention of your interest. I hope this cargo will not cost more than twenty eight livres per charge, including freight, delivered at Marseilles, and between this and the price of thirtyfive to forty livres per charge is a very fair margin." Wheat was then selling in Philadelphia at seven shillings a bushel and flour at forty-three shillings, or about five and three quarters dollars a barrel.

Towards the purchase of the wheat there were now shipped to Messrs. William and James Douglas, Petersburg, Virginia, eight hundred Spanish silver dollars, twelve half dollars, thirty-six French crowns and six hundred and sixteen quarter dollars. Other remittances of specie were made later. One of these is of interest as showing the variety of coins in circulation in 1789 . The sum sent was one thousand dollars and the gold coins were Io doubloons, 5 half doubloons, 4I quarter doubloons, 8 one-eighth doubloons; 7 one-sixteenth doubloons, 2 Johannes, I 7 half, I quarter, I eighth and two sixteenth Johannes; 2 double and I single French guineas, 4 moi- 
dores, I ducat, 73 English guineas and $\mathrm{I}_{4}$ half guineas. They passed by weight, not by tale, and as the weight was I 25 pennyweights, their value at 6 shillings 8 pence per pennyweight was one thousand dollars. With these remittances there was purchased fourteen thousand bushels of wheat. Before the Ann left Petersburg, Tyson sold his share in the cargo to Girard.

So great was the demand for wheat in France that the entire cargo was marketed before it arrived for forty livres a charge, the government bounty of three livres, fifteen sous to go to the purchaser. "You must know" M. Samatan wrote, "that our Revolution, which is nothing less than the destruction of the monarchy, has thrown the Government into complete disorder which has affected and discredited the whole commerce of France. The principal cities abroad, such as London, Amsterdam, and Cadiz, are loath to negotiate paper in France and that is the reason why I have not yet sent you two or three vessels with piastres from Cadiz."

The two he did send, L'Etoile Mignonne, and Le Héron, arrived in November with fourteen thousand piastres fortes; "but owing to the increase in the price of wheat the money will not suffice to complete their cargoes." Wheat was then selling for a piastre forte and $5 / 90$ a bushel; but such was the demand for it in France that Girard urged the Cadiz correspondent of Samatan to charter three or four vessels, for the account of $M$. Samatan, "ballast them with good white salt and despatch them at once with piastres for this port to my address." For himself he chartered an English brig, the Active; and ordered the purchase at Petersburg, Virginia, of twenty thousand bushels of wheat provided the price per bushel of sixty pounds was not greater than five shillings sixpence, Virginia currency. By the middle of December 
all these vessels were at sea, and the Polly came in from Cap Français and was at once sent to Marseilles.

"She arrived here," Girard wrote M. Samatan, to whom she was consigned, "on the 19th instant at two o'clock in the afternoon with a cargo of syrup and coffee, and on the 22nd I sent her off again, making only three days including Sunday." Her outgoing cargo consisted of six hundred and eighty-one barrels and sixty-two half barrels of flour and "six hundred white oak staves with bottoms to match." When the new year opened wheat had risen, and all prospect of profit disappeared, and Girard closed his speculation.

"Navigation on our river," M. Samatan was informed in January, "has not yet been interrupted by the ice and this fact, added to the great demand for wheat, has sent the price of that article up to one piastre forte and $18 / 90$ per bushel. This price forbids my making the purchases that I hoped to make on shares with you. It is my opinion that this commodity has not yet reached its highest price, and I know that less than one third of the last crop remains in the warehouses of the country. I therefore, think it prudent to abandon all our plans and, accordingly request you to countermand the orders you or I have given to Messrs. Rey and Brandenbourg, of Cadiz, to charter vessels for our account, and to cancel any orders you have given elsewhere."

Rey \& Brandenbourg were also notified to cancel any charter parties they had executed. "The great demand that prevails here for wheat and flour has sent the price of the former article up to $9 s .4 d$. per bushel, and that of the latter to $475.6 d$. per barrel, and I believe these commodities are destined to increase to Io shillings. If, by any chance you have sent me the vessels that I asked 


\section{A SPECULATION IN WHEAT}

you for, for the account of M. Samatan, I shall do my best not to send them back empty."

High as were the prices of wheat and flour he was sure great profits could still be made, so sure that he declared to his brother, "If I were there (Cap Français) at this present moment I should sell all I have in the world to speculate in this article even at 7 gourdes a barrel. At the present moment it is worth 47 shillings 6 pence per barrel and will increase still more. I should not be surprised to see the price reach 52 shillings 6 pence per barrel before long." News from Virginia confirmed this belief. His Petersburg correspondent sent word it was not possible to fill his orders. Wheat was not to be had. Corn was selling at ten to twelve shillings per barrel of five bushels, but this, too, would rise, and if Girard intended to buy there was no time to lose. Another wrote that wheat could not be purchased at seven shillings, and that corn would soon be three shillings a bushel. By the middle of January 1790 wheat brought eight shillings, Virginia money, or one and a third dollars in cash; and from the demand and scarcity of the grain it was expected the price would be ten shillings before the next harvest. Late advices from France gave the price in that country as twelve livres, almost $21 / 4$ dollars, a bushel while the Government bounty nearly paid the freight.

The order to Rey and Brandenbourg came too late. The Neptune, Le duc de Chartres, La Bonne Alexandrine, and Le Temple de Solomon had already been despatched from Cadiz with salt for ballast and piastres for the purchase of wheat. But, when wheat rose to twelve shillings a bushel, Girard ceased to buy and ordered ten thousand bushels of corn from William \& James Douglas, at Petersburg. They were to pay not more 103 
than six shillings, Virginia currency, a bushel and send the corn to Philadelphia.

While waiting for the grain to arrive Girard chartered the ship San Pedro to go to Norfolk for corn to be sent thence to Cadiz, and so informed Samatan.

"The above mentioned vessel was built in Holland and belongs to merchants in St. Sebastian who sent her here to load flour. But, as they limited the price to 45 shilling per barrel, and, in addition, did not send any specie for the purchase of the said cargo, the consignees were unable to execute their orders, and decided to charter the vessel to me at the rate of one-fifth piastre forte per bushel and two and one-half per cent. for damages, master's gratuity, \&c. You will place an insurance for my account with good insurance companies of 12,000 livres tournois on my half of the cargo of Indian corn." Wheat was then at $13 \mathrm{~s}$. per bushel and superfine flour at $57 \mathrm{~s} .6 \mathrm{~d}$. per barrel, cash.

Late in April the Neptune arrived with 8000 piastre fortes and fifty lasts of salt, and when so informing Rey \& Brandenburg Girard told them that wheat was 13 shillings 6 pence a bushel and flour 60 shillings a barrel; that it was practically impossible to obtain a cargo of wheat, that the brig would therefore go back loaded with corn, and that the San Pedro, likewise laden with corn, would sail at once from Norfolk consigned to them.

By this time a dispute, long gathering head, ended in the rupture of all business relations between the brothers.

The quarrel with Jean made it necessary to find a new correspondent at Le Cap. The firm of Aubert, Rouch \& Co. was accordingly selected and the brig Kitty, Captain John Justice, was consigned to it with a cargo valued at 2077 pounds. The Kitty was a brig of $921 / 2$ 
tons, had one deck and two masts and was purchased from Captain Cochran for $£ 600$ Pennsylvania currency.

In return for the cargo, Aubert, Rouch \& Co. were to send back two or three thousand piastre gourdes in specie, fifty hogsheads in syrup and some trade coffee. $\mathrm{He}$ hoped this venture would encourage him to send more shipments. $\mathrm{He}$ was expecting the arrival of a small brig from Marseilles and intended to keep these two vessels constantly plying between Philadelphia and Le Cap with cargoes quite important considering the size of the vessels, and hoped Aubert, Rouch \& Co. would bear this in mind in the matter of commissions. He was the owner of another French vessel of about two hundred tons, and might send her to Le Cap with flour and lumber, to be thence despatched to Marseilles with a half, or two thirds, of her cargo in freight.

"My brother's firm," he continued, "has been doing my business at Le Cap up to the present time; but, as there is a misunderstanding between us, or rather as he is charging me with certain items contrary to our agreement, I have decided to settle accounts with him, and therefore send you his account current, requesting you to pay him the balance after deducting the following sums: for storage charged in the last three accounts of sale made in January and February last, contrary to our agreement, 1725 livres; for one bag of coffee charged on the invoice for the last voyage of the brig Polly, which bag was not loaded on board the said vessel, I 40 livres, I sou, 2 deniers, bringing the balance down to 6663 livres, 15 sous, 6 deniers. You will pay him this sum for my account provided, of course, he gives you a receipt for payment in full of all accounts with me, and you will take the precaution to have him sign three receipts and send two copies to me. My agreement with my said 
brother was, that I should pay him $5 \%$ for storage and selling commission, and $2 \mathrm{~T} / 2 \%$ on remittances, and that besides, we should allow one another one-third of all commissions arising from all business procured for one another. If these conditions were fulfilled there would be a balance in my favor; but as I am adverse to quarreling I waive my rights in this last matter." Flour was then 65 shillings a barrel and wheat 14 shillings a bushel.

May twentieth the Polly reached Le Cap. What then happened is narrated in a letter from Aubert, Rouch \& Co.: "Immediately on the arrival of your brigantine your brother, to whom we had not communicated your intentions as we had not seen him before, took the precaution to file a protest at the admiralty office against the vessel's return, a step he should never have taken without first letting us know. When we met him we' proposed to settle with him whenever he wished, and he thereupon brought his books with him to prove the item with which he charged you in your account.

"On examining his books we found like yourself, my dear Sir, that he was charging storage in three accounts of sale to the amount of 1725 livres, as he had been unable to put your goods into his warehouse. He proved to us that he had paid for the storage by receipted bills which he showed us. To contest this item you should have sent us his letters in which he agreed to include storage in the $5 \%$ commission which you allowed him. If you have no such letters we believe you would lose in a law suit because it is lawful to charge storage on every kind of merchandise. As he intends to bring suit to recover, which would put you to considerable expense for litigation, we thought it better for your interests to allow him to make his reservations on the account agreed on, and also allow him 10\% re-draft on the bill of exchange that he 


\section{A SPECULATION IN WHEAT}

had drawn on you in favor of Mr. Bell, in settlement of the account, which draft you allowed to go to protest.

"You will see by the said account agreed on, which we enclose, that we have entered all the necessary protests in your name, and that we consented to become the trustees for the sum of 3300 livres for the items reserved by him, including the value of his certificates that you have in your possession." In short, the 1725 livres for storage and the I4O livres for the lost bag of coffee were deducted from the 865I livres demanded by Jean Girard, and 6786 livres were "paid him at once."

Aubert, Rouch \& Co. did not think it wise to send a vessel to Le Cap to go thence to Marseilles. It was difficult to get freight for any vessel not belonging to the harbor of Marseilles. Merchants who sent freight to that city always preferred Provençal vessels because insurance was less than on a foreign ship. The cargo of flour was of such fine quality that it sold at from 90 livres I 5 sous to 99 livres a barrel, and some of the rice at from 28 to 32 livres a hundredweight. The entire cargo netted 5I,529 livres I sou, I denier.

When Samatan heard of the proposed voyage of $\mathrm{La}$ $V$ irginie to Cadiz, and the purchase of maize he protested vigorously. "It will be most unfortunate if the vessel is delayed or stopped altogether at Cadiz. Nevertheless I have written to Messrs. Rey and Brandenbourg if they find an opportunity to sell Captain Dot's cargo at a better price than $4^{\mathrm{I}}$ to $4 \mathrm{I}$ livres Io sous, which is what I hope to realize here, to close the deal, procure freight for the vessel as far as Marseilles, which is very easy to do, and send her to me at once. I think that is all right, but what is not all right, far from it, is your purchase of maize in Virginia at 3 piastre fortes for 5 bushels. I calculate it will cost you 20 livres per charge, and that is 
all I can get for it here. Wheat would have been more suitable as I told you in my letter, and, if there is still time, I advise you for the good of our common interest to sell the maize, and load flour or rye, preferably flour, because I can always sell it at 38 or even 40 livres per barrel. Let this be a lesson to you for another time, not to pay more than 2 piastres for five bushels."

Ill luck attended the flour speculation. About the middle of March La Virginie sailed from Delaware Bay and meeting heavy weather began to leak. When two days out, wrote Captain Dot:

'The sea was very high and the brig leaked to such an extent that she took in water as far as the brace of the mainstay. On the 25th and 26th the bad weather continuing, we pumped every hour. On the 27th at three o'clock in the morning we encountered a squall which made us careen a great deal and a moment later the pump was manned and I noticed for the first time that we were pumping wheat. At six o'clock that same night and at seven o'clock the pump brought up as much wheat as the pump hose could hold. At eight o'clock our pump became choked, and brought up neither wheat nor water. The wind was coming from the southwest, and we were in the starboard tack. I at once started the starboard pump which brought up the same quantity of wheat and water as the other. I noticed that the wheat we were pumping was chiefly white, and concluded that the leak was in the between decks. I went down at once with my second, tore off a few planks from the bulkheads and advanced to the larboard gallery. My progress was stopped after I had barely taken two steps as the cleats to which the uprights were nailed were broken or torn out of their places. The entire gallery had come on deck, and the 
wheat was running out through the planking which was missing the entire length of the between decks."

After finishing such repairs as were possible "we crossed over to the starboard gallery and found that it had also caved in like the other and that the bulkheads were on board. We were making 18 feet of water, one pump was choked, and we feared every moment that the same thing would happen to the other. Concluding that we were some leagues from Cape Delaware, we put the ship about and laid her head to the northwest," and during fifteen days beat up and down the sea without making ten leagues to the westward.

April twentieth the course was again changed and on May 18th Captain Dot found himself outside the bay of Cadiz. "After going through all sorts of manœuvres to call a pilot, the wind being in the north and the tide full, and fearing that I might get under the lea of the bay, I decided to enter the harbor at six o'clock. The wind shifted and became scant. As the tide went down the brig struggled and we grounded, and an instant later we were forced a foot over the bar. An hour or two later a small boat and a Spanish gun boat came out with anchors with which they anchored the boat from the stern."

The wheat in the between decks was finally taken out, the brig floated and brought into the middle of the bay, and at the request of Rey \& Brandenbourg the consul appointed experts to examine the wheat and captains to examine the ship. To satisfy the captains $L a V i r-$ ginie was run aground, careened and repaired. Such of the wheat as was damaged was sold for what it would bring; the rest was sent in the brig to Marseilles.

"I was unloading the ship as fast as possible so as to hasten this expedition," wrote Samatan, "and while the wheat was being unloaded I began to sell, first, bad 
charges at 30 livres with discount of $2 \%$, then 77 charges at 30 to 32 which was more than I hoped for in view of the present state of the article, and I was beginning to hope that I should be able to sell it all at that price when I heard that the warehouse where it had been stored had collapsed. You may imagine what I said at the time, for I might have received this cargo six weeks earlier if it had come here direct, and I could have sold for 40 livres at the end of May, at which time the vessel might have arrived, and then to lose this through the most unfortunate and unforeseen circumstances.

"I had I 300 charges of Sicilian wheat in this same warehouse, which is owned by a M. Reynard. I at once offered to give up everything to the owner of the property on condition that he would pay me the value of 1082 charges of Virginia wheat and 1300 charges of Sicilian. The judges, without listening to my offer, had the grain taken from the wreck without making any estimate of the damage. Up to the present time, August 3, they have recovered about 2200 charges, as much of one as of the other, which they have delivered to me, after having it put in the best possible shape. Noticing that the wheat was damaged, I claimed some idemnity, and shall accept nothing less than the first valuation. When this is settled I shall sue M. Reynard for the balance." Unhappily for this plan M. Reynard fell dead when he heard of the collapse of his warehouse and according to the law three months must elapse before the heirs could be sued.

The next to be heard from was the San Pedro which sailed from Norfolk late in May, and after a long and stormy voyage reached Cadiz. Her cargo consisted of 6600 bushels of Indian corn, in which M. Samatan had declined to take a share, and which Rey \& Brandenbourg informed Girard arrived completely spoiled. 
"The Captain, who had a very stormy voyage made his declaration (son protêt de mer) at once, and we had sworn experts officially appointed to go on board and examine the cargo. On the strength of their report, the gist of which was that they found the Indian corn almost totally ruined and rotten, unfit to be transported and good for nothing save to feed to animals, we could see nothing better for your interests than to abandon the cargo for the account of whomsoever it might belong. Accordingly we petitioned our Governor to permit us to abandon the cargo and have it sold at public auction. Our petition having been granted we at once proceeded to hold a public sale of the Indian corn on the San Pedro and it was carried out with all the formalities ordained by custom and required by law."

La Bonne Alexandrine, in the cargo of which Girard had a half interest, was searched by an Algerian pirate, was forced to pay a ransom, was held eighteen days in quarantine, spent two months and a half on the voyage and so lost the market when at its best. The cargo of the Polly netted 34,599 livres eleven sous; and half that of the $A n n 42,753$ livres, 18 sous, 6 deniers.

His new correspondent at Le Cap, Aubert, Rouch \& Co., now added to his discomfort by reporting a poor market. During the early part of July fine flour had been selling at 13 gourdes per barrel, but "During these last two days ten vessels have arrived from various ports on the continent, among them one from Baltimore and two from your port. These vessels were undoubtedly loaded with flour, and the effect has been to bring the price down to I 2 gourdes. The arrival of such a large number of vessels has sent the price of molasses up to $56 \mathrm{~s}$. to be loaded from barges in the harbor, with the money on the bung. We say this for the benefit of certain persons who, 
on the arrival of their vessels, have not the means to do this, so that their captains find it very difficult to sail away again as promptly as they could wish. The scarcity of cash is inconceivable. Even the Americans need not hope to get gourdes in return for they have carried away too many already."

When therefore, the Kitty and the Sally arrived with cargoes of flour and orders to bring home syrup Aubert, Rouch \& Co. were unable to fill the order.

"A sudden rise in syrups which are still selling at 64 s. and the impossibility of engaging any from the plantations where they roll raw sugar, on account of the great drought that we have just experienced and which has greatly diminished the output, have made us," Aubert, Rouch \& Co. wrote, "abandon all efforts in this direction." Raw sugar was therefore sent as a remittance. But even this was hard to get. "There was not a single barrel to be had in town" and the owners of plantations refusing to deliver their sugar in the harbor forced the buyer to haul it away in carts, barrel and load it on board. Some of the flour sold for from I I to I 2 gourdes; but the price fell to ten, and four hundred barrels were sold before the Kitty set out on her return voyage for $91 / 2$ gourdes. Her return cargo of raw sugar, coffee and cocoa was valued at 42,000 livres.

Neither the high price of syrup nor the low price of flour discouraged Girard. His ships must be kept busy, and the Polly having returned from Marseilles and Cette early in August, went back to the San Domingo trade consigned to Aubert, Rouch \& Co. On her first voyage she carried a cargo of flour worth 2376 pounds.

The net proceeds finally amounted to $43,15 \mathrm{I}$ livres I 5 sous. Business at Le Cap had been much interfered with because of the absence of buyers on an expedition 
against a band of Mulatto brigands in the mountains. They were "Led by a chief of their own who was brought here by an American vessel and who is persuading his followers that they ought to be admitted to equal rights with the whites. We have about 300 men, made up of regular troops and citizens from the town, the plains and the mountains, who are pursuing them, and we have no doubt that they will succeed in pulling them down. Their communications have been cut off and we have been combining with our neighbors, the Spaniards, to force them back into their entrenchments. These bandits live in the mountain wilderness and are very difficult to capture; on the plain they would not have resisted for a moment."

That the ports of the island would soon be closed to American flour was not unlikely. "Our Bordelaise captains are doing everything in their power to drive away Americans at the Môle because, they say, they cannot sell their flour for ten and twelve gourdes. They have presented a petition to our Assembly; but it was decided there was not, as yet, any occasion to act on the subject. We shall do everything in our power, and other parties interested will do the same, to put off the rendering of a decree."

The next letter from Le Cap warned Girard not to let any of his captains bring "a single barrel of powder save for use of the vessel, and not to take on board any suspicious passengers. We know that a number of mulattoes expect to come here by way of New England. Captain Brown of Wilmington, North Carolina, who brought us the mulatto Chief, is still in prison and his vessel in a fair way to be confiscated. As our mulatto bands are captured our anxiety is allayed. We do not fear them in this part of the country as we have powerful means

Vol. I-8 
of suppressing them. The Cayas party is also making a powerful effort to force them to return to their territory."

With flour selling at six and a half gourdes the barrel at Le Cap and forty-six shillings or about six dollars and 12/90 at Philadelphia, there was no profit in that article; but sugar sold for 55 to 60 shillings at Le Cap and 83 shillings $6 \mathrm{~d}$, or II ${ }^{15} / 90$ gourdes for I I 2 pounds in Philadelphia. Girard, therefore, continued to send cargoes of flour by the Sally, a brig owned by his old Captain, Cochran, and by his own vessels, Kitty and Polly, which brought back raw sugar and coffee of the second quality "good enough for this market."

The Kitty, on a return voyage from Le Cap, was struck by a squall, lost some of her canvas and went ashore at the entrance of Delaware Bay. Girard hastened to her assistance, and "after an absence of two weeks and much fatigue succeeded in saving the entire cargo," except 30 quintals of sugar and I 100 pounds of coffee which were stolen, "and bringing it back to Philadelphia in good condition." "As for the brig, I hoped to be able to get her afloat again, but I am afraid it will be a long and costly operation and I am afraid I shall not be able to send her back to you before April or May next," he wrote Aubert, Rouch \& Co.

Scarcely had he returned from the wreck when bad news came from the unfortunate La Virginie. She left Marseilles in September and after a voyage of more than three months entered Delaware Bay, and December sixteenth, reached New Castle. From there Captain Dot wrote: "I left Marseilles on the 6th of September and on the $24^{\text {th }}$ of that month I was outside the straits. On the 24th of October I had passed the Bermudas and finally, my dear Sir, I have been fifty days on the coast going through gale after gale, without provisions and having 
no water to drink except what fell from the sky, part of my sails carried off and nothing to mend them with. I had caught sight of Cape Henlopen for the third time when the pilot came on board."

The news was most welcome, "but an instant later," Girard told his Baltimore correspondent, "word was brought that the said brig had left the latter port (Marcus Hook) and the wind having failed she had gotten among the ice. I at once went to her assistance and with the help of friends and about twenty willing men, I was fortunate enough to bring her safely into the wharf at Marcus Hook on this igth of the month. There are on board the latter vessel for my account about fourteen thousand gallons of brandy, and one hundred barrels of white wine." A little later, the river having opened, $L a$ Virginie was brought to Philadelphia.

While the Kitty was stranded at Broadkiln, and $L a$ Virginie undergoing repairs at Philadelphia, the Polly was making trips to San Domingo and Charleston.

On one of these trips in March as the brig was about to sail for home, at nine o'clock in the evening, just as Aubert, Rouch \& Co. were handing to Captain Edger his papers, Jean Girard appeared and delivered this letter:

"The repeated refusal to pay me the $\mathbf{1 7 2 5}$ livres which the Sieur Stephen Girard lawfully owes me has induced me to inform you of my resolution to adopt violent measures if you do not pay me, this very hour, the small sum in question and bury the past so far as possible. If you will not do so I have decided to denounce the brig Polly, to expose you to the payment of a fine, and your correspondent to considerable loss. Although I shall also be exposed to criticism I shall suffer less than anyone else because it will bring me in more than is owing me, and 


\section{THE LIFE AND TIMES OF STEPHEN GIRARD}

prevent those who profess to be supporting the interests of the mother country, from violating the custom laws. My excuse will be found in the following reasons which are indelibly impressed on my memory.

"First, the Sieur Stephen Girard, before we formed our partnership and during a period of almost two years, had belonging to me from 60 to 80,000 livres without paying me a sou of interest, although he had the effrontery to charge me interest and commission on 60 gourdes which he advanced on my account to M. J. Mayer, as appears in his letter, and that at a time when I was advancing to him the greater part of the proceeds from his cargoes without charging him any interest whatsoever.

"Second, the Sieur Stephen Girard, who has always had money belonging to me, as he was my partner, had the audacity although I had the signatures of both houses at Le Cap and at Philadelphia, while he had but the latter, to call upon Mr. Willing, President of the Bank, to request him not to honor my checks on the ground that I wished to dissolve partnership with him. To accomplish this object he paid me nearly 20,000 livres.

"Third, the Sieur Stephen Girard, to whom I had often made advances on various cargoes of his brig to the sum of 90,000 livres, in order to redispatch her from here at once, was cruel enough, at a time when he owed me 8000 some hundred livres balance, to allow my draft for that sum to be protested on the pretext that he did not owe me the 1725 livres.

"Fourth, the Sieur Stephen Girard, because I left him, resolved to ruin my reputation both here and in Philadelphia, first at the bank and then among the general public, by means of the above mentioned protest; and finally at the time when M. Mayer was basely calum- 
niating me, to take his business away from my firm for the alleged reason that $I$ refused to advance him any more money, and in that way tried to prove to all the captains from the continent that the above-mentioned calumnies had some foundation, although they were false as you may see by the enclosed writing. My enemies and rivals profited by the last attack on the part of the Sieur Stephen Girard who has thereby deprived me of all business in that line. ***

"I wish for no other reply than the immediate payment of the sum due in specie, and will give a full receipt for the same endorsed on the back of the account-current on which we have agreed, If this is done I shall be satisfied, and if not, nothing in the world will longer restrain my just revenge. I have the honor to be, \&c."

"P.S. The official declaration calls for 180 quintals of sugar and 7500 pounds of coffee, which is quite different from the cargo, which consists of at least 380 quintals of sugar and 20,000 pounds of coffee."

The postscript was the important part of the letter, and "What," asked Aubert, Rouch \& Co. in narrating the incident to Girard, "What, was to be done in such a contingency? As he did not give us time to think, we thought it wise for your interests to accede to his demands, for after such threats he was capable of carrying out his evil intentions which would have cruelly exposed both you and ourselves. We therefore did not hesitate to sacrifice the 1725 livres, on your account, in payment of the items of storage which you disputed in his accounts, and accordingly paid him the said sum at once."

"The questionable methods used by your brother to obtain this payment would have been enough to make us refuse, but, as we did not feel that we had a strong case, as you will readily see by the comparison he makes 
in the postscript to his letter, we should have been very much compromised as there was a difference of more than one-half. You cannot fail to approve of the steps we have taken in this matter, dear Sir, as it was of the greatest importance to your interests. Your brother chose his time well for the success of his design; had he made his threat earlier we could perhaps have found means to avert the blow. He was kind enough to tell us that this plan to punish you for your injustice to him had been in his mind every time your vessels came to port, and added that had the vessels been consigned to any other firm than ours he would have carried it out long ago."

How Jean Girard became aware that the cargo was larger than acknowledged was told in another letter from Aubert, Rouch \& Co. "You will see that the sum of I48-10 has been spent in gratifications for the Custom House inspectors. All the Americans are in the habit of paying this sum to these gentlemen for a reason that you can readily imagine. Moregver we cannot blame them as they consider it absolutely necessary. One must make small sacrifices and they all come back in another form; besides it is an established custom among all the American commission men. We had not as yet conformed to it when, speaking to one of them about the abominable conduct of your brother towards us, we were told that probably we had not complied with all the usages, and that was the reason your brother was able, without any trouble, to find out of what the cargo of the preceding voyage consisted. We are inclined to think that this is so, and that it is absolutely necessary to prevent a like occurrence in future."

"I wish you to know the truth." was the reply. "My brother having requested me to form a partnership with him I unfortunately consented. His contribution to the 


\section{A SPECULATION IN WHEAT}

common capital was found a business at the Cape, as a branch of the Philadelphia house, and a balance in cash. To make up the amount of the latter he was obliged to have funds in Philadelphia and for this purpose made certain remittances in commodities a few months before our partnership was established. Since that time I have never received any money from him: on the contrary, the balance on the goods sent to him from time to time has always been in my favor, until the settlement of the last account, in which I find that I owe a little on a remittance of coffee made for my account, at an enormous price and freight, per Captain Anselmo to the address of $M$. Samatan of Marseilles. I have too much respect for the name I inherited from my late father ever to have harbored the slightest intention of ruining his reputation or his credit. According to our contract I was to have charge of the funds; during my absence he was to have charge of them. When I returned from Europe I resumed the management of the business, and though I was cashier, our firm signature was recognized at the bank. At a time when I had strong reasons to be dissatisfied with his conduct he took advantage of the confidence reposed in him to draw a check in the name of the firm for about 200 gourdes more than we had in bank. His check was honored and as a precaution he placed the money in his own cash box. A few days later when I was at the bank, a clerk called my attention to the mistake. I assure you I felt this very keenly and after reflecting a moment I answered that I was not its author. Such conduct on the part of my brother led me to close the firm account in the said bank, and open another in my own name, which I had a right to do in my capacity as cashier."

During the summer of I79I the Kitty and the Polly continued to ply back and forth between Philadelphia 
and Le Cap, and each trip the news they brought became more and more discouraging. Flour was selling for $61 / 2$ to 7 gourdes, and money was almost impossible to get. "You have no idea, my dear Sir, how scarce money has become here," wrote Aubert, Rouch \& Co. "There has never been anything like it. What is even more astonishing is that we have not been able to collect the price of a single barrel of flour of the two last cargoes. I have urged and solicited the buyers in the hope of collecting the sum of 1000 gourdes which we would then have sent you, but all our efforts were in vain."

"We cannot tell you as yet what the law will be in regard to the admission of your flour to the port. It depends on the arrival of the Civil Commissioners whom the National Assembly are to send into the Colony and on the convening of the Colonial Assembly, which will decide this important question as well as the exportation of our products to your continent."

"You cannot conceive how difficult collections are. We are a little easy with our debtors because the money is placed and because the chief reason for the delay is the want of ready cash which is growing from day to day. We are going through a critical period just now and the effect on business is anything but good. Our National Assembly is meditating the passing of a decree placing all colored persons born of free parents on an equality with the whites. The people of our colony are resolved not to accept this law. We shall remain firm and unyielding in this determination and hope the $\mathrm{Na}$ tional Assembly will revise the decree which was passed by dint of intrigue."

Girard now sought a market at Port-au-Prince. "Owing to the low price you quote for flour, the scarcity of good brands in Philadelphia, and the large quantity that 


\section{A SPECULATION IN WHEAT}

has been shipped to your port, I have decided to accept an offer of $1 / 2$ gourde per barrel freight for a full cargo for the brig Polly, Captain William Edger, to go to Portau-Prince." On the way the captain was to stop at Le Cap and obtain the name of a reliable firm, at Port-auPrince, to purchase and load fifty barrels of raw sugar. To pay for the sugar the Captain would take along 5000 piastres gourdes in specie. The firm must not be overloaded with American business and must be willing to go into the country, cash in hand, and make the purchase.

The voyage was accordingly made and the Polly consigned to Etienne Patot \& Co. at Port-au-Prince reached that port August fourteenth. A week later when writing to inform Girard that they had heard of her arrival, Aubert, Rouch \& Co. remarked that, "our Colonial Assembly which convened at Leogane to select a place to hold its sessions, have just decided to hold them here and the opening of the Assembly is fixed for the 25th instant. We are not at all displeased, as the establishing of the Assembly here, and the fact that its members will stay here for some time, may give an impetus to business and increase the consumption of your flour and this will cause a rise in price which is still 5 to $5 \frac{1}{2}$ gourdes per barrel."

Unhappily, on the 23d of August, I79r, the slaves rose in insurrection and swept over the plain to the eastward of Le Cap, burning the houses of the planters, the factories and the sugar cane, and murdering the whites by hundreds. 


\section{CHAPTER IV}

\section{SAN DOMINGO AND MARSEILLES}

OF all the West Indian colonies, the fairest, the richest, the most prosperous, in 1789 ,was French San Domingo, La Partie Française de Saint-Domingue. It comprised the western end of the island Columbus had called Hispaniola, and was divided into three provinces-the North, the West, and the South.

The population of the three in 1789 amounted, according to the Intendant Barbe-Marbois, to thirty-five thousand whites, twenty-six thousand mulattoes and free people of color, and some four hundred thousand negro slaves. The chief exports were clayed, or soft white sugar; muscovado, or raw sugar; coffee, cotton, indigo, molasses, an inferior rum called taffia, and hides.

In the North province were the towns of Cape Français, commonly called Le Cap, Fort Dauphin, Port de Paix, and Cap Saint Nicholas. Le Cap, with a population of twenty thousand souls, lay at the foot of a high mountain called Le Morne du Cap. To the east, stretching away for fifty miles, was a great plain devoted solely to cultivation of sugar. Cap St. Nicholas, a smaller town of some two.hundred and fifty wooden houses, nestling beneath a high bluff called the Môle, was the chief resort of ships from our country.

Port-au-Prince in the Western Province, the metropolis of the French Colony, numbered some six hundred houses. In the Southern Province were no safe harbors, and but three towns of importance, Jérémie, Les Cayes and Jacmel.

Government of the colony was administered by the Governor-General, who represented the Crown, com- 
manded the regular military forces and the militia, and was the medium of external relations, and the Intendant, who stood at the head of the civil administration and the judiciary. But the powers of neither had ever been well defined and the result was constant rivalry and misgovernment.

So bad was the administration of government that no sooner had the call for the meeting of the Estates General gone forth in France than a movement to secure representation for San Domingo was started by those most interested in the welfare of the colony, and planters and merchants of San Domingo resident in Paris, and absentee nobles who owned great plantations but had never visited the island, formed, in July 1788 , the Colonial Committee. In the Colony a number of planters of noble birth, merchants, lawyers, and the Chamber of Commerce of Le Cap took the lead. Provincial meetings were held, resolutions asserting the right of San Domingo to be represented in the Estates General were adopted, and finally eighteen delegates, six from each Province, were elected and sent to Paris. When they reached that city, late in June 1789, the Estates General had become the National Assembly, to which, in time, six of them were admitted.

From the National Assembly came the "Declaration of the Rights of Man," asserting principles which struck at the very root of slavery. Were such legislation to continue the colony was doomed: San Domingo therefore must be taken from the control of the National Assembly and her affairs entrusted to some governing body friendly to the existence of slavery. La Luzerne, Minister of Marine, whose authority over the Colonies was supreme, was accordingly besought by the Colonial Committee to convoke a Colonial Assembly, accountable 
to no one save the King. This was granted, and, in September 1789, orders were sent to the Governor-General to provide for an Assembly to regulate the internal affairs of the colony.

It was January 1790 before the orders reached the Governor and ere that time the Colonists had begun to act for themselves. The Intendant, Marbois, had been forced to flee from the island; Provincial Assemblies of the North, the West and the South met at Cap Français, at Port-au-Prince, and at Les Cayes and by these three, a Colonial Assembly was convoked to meet at SaintMarc on the 25th of March, where, on May 28th, I790, it adopted a rude form of Constitution for the French part of San Domingo.

That so radical a change should alarm the upholders of the old despotic form of government was but natural. The cry was raised that the purpose of the Assembly was to make the colony independent of the Crown. Some of the parishes of the Western Province thereupon recalled their deputies; the people of Cap Français renounced obedience to the General Assembly and petitioned the Governor to dissolve it at once. A proclamation dissolving the General Assembly was accordingly issued, the members declared traitors to their country and enemies to the King, and a hundred men were sent to seize the committee of the Western Provincial Assembly. But they had gathered four hundred men and, after a skirmish, the troops of the Governor withdrew.

Hearing of this attack, the General Assembly summoned the people to arm in its defence and preparations for a civil war were made by both sides when, suddenly and unexpectedly, 85 of the 100 members to which the General Assembly was reduced by desertion, boarded a government ship and on the 8th of August sailed for France to lay their case before the King. 
Until this time neither the mulattoes nor the slaves had taken any part in political disturbances on the island. But there was then living in Paris a young man named James Ogé, the son of a mulatto woman by a white planter, and a native of San Domingo. Excited by the principles of the French Revolution, believing that he could lead the blacks to liberty, and aided by a society called Les Amis des Noirs, he came to the United States, procured arms and ammunition, landed secretly from an American sloop in October 1790, and established a camp at Grande Rivière, some fifteen miles from Cap Français. There he was attacked by regular troops and militia, his followers routed and driven into the mountains, and Ogé forced to seek a refuge in Spanish territory.

Both parties now flew to arms. The mulattoes formed camps at Verette, Anti-bonite, Jérémie and Les Cayes. The whites gathered in force near Verette; but the Chevalier Manduit, Colonel of the regiment at Port-au-Prince, persuaded the mulattoes to disperse.

In November 1790 the Governor-General, M. Peynier, resigned; M. Blanchelande took his place, and demanded and obtained from the Spaniards the delivery of Ogé, who with some twenty of his followers suffered death in March I79I.

The mulatto chief brought by Captain Brown from Wilmington was Ogé and for this act the Captain was heavily fined.

The five and eighty deputies who sailed for France in August 1790 landed at Brest in September and were promptly ordered by the National Assembly to appear before it at Paris. Only one audience was allowed them, and at this they were indignantly dismissed from the bar. In October a report by M. Barnade recommended that all decrees of the Colonial Assembly be declared 
null and void, that the Assembly be dissolved, that the King give orders for a new Assembly to be established on the principles set forth in the National decree of March 8 th, 1790 , and that the deputies remain in a state of arrest, and a naval and military force was ordered to San Domingo to uphold the authority of the King.

The National Assembly, led on by the Abbé Grégoire, Condorcet, and Robespierre, now turned its attention to the mulattoes and on the I5th of May, I79I, passed another decree ordering "that the people of color resident in the French Colonies born of free parents, were entitled to, as of right, and should be allowed the enjoyment of, all the privileges of French citizens, and among them that of having votes in the choice of representatives, and of being eligible to seats both in the parochial and colonial assemblies." This was the decree to which Aubert, Rouch \& Co. referred in their letter.

When news of its passage reached Cap Français on the 3oth of June, I79I, rage and indignation spread throughout the colony. The Assembly of the Northern Province called for a new Colonial Assembly and on the 9th of August 176 deputies met at Léogane and soon adjourned to meet at Cap Français on August 25th. But, as Aubert, Rouch \& Co. had stated, on the morning of August 23rd, just at break of day, the people of Cap Français were aroused by messengers who reported that the slaves in the nearby parishes had revolted, and were burning buildings and massacring the whites on all the plantations on the plain. The horrors of that massacre and the details of the fights and skirmishes that followed, how the revolt spread to the Southern Province and what there befel, need not be narrated. It is said that in less than two months more than a thousand sugar, coffee and indigo plantations were destroyed, and more than two 
thousand whites massacred. Among the sufferers was M. Aubert.

"In this Province," said a member of the firm, "from Pt. Margot to Limonade, a level plain of about 20 leagues, these maniacs have set fire to all the plantations and massacred all the whites they could find. Words fail me in trying to describe all the horrors they have committed. In possession of the entire plain, they have divided into bands of from three to four hundred, distributed on the various plantations which provide refuge for them. The handful of men at our command are all needed to occupy the most important fortified camps by which the city is defended, and we have none left for making sorties against them from time to time when they come too near. If we had a few more troops of the line we could surround and besiege them in their refuges. These brigands are too numerous for us to think of attacking them as they have forced all the laboring men to follow them, although against their wills. Those who attempted to get away have been massacred like the whites.

"After laying waste the entire plain they tried to force their way into the mountains. They met with practically no resistance on Grand Rivière as the inhabitants, several of whom fell victims to their rage, are too few in that region. They have set fire to all homes in their path.

"Our M. Aubert who was on his plantation, and to whom we had sent warning, just succeeded in escaping to the city with his family. Had he delayed leaving his refinery, where he had been for two hours trying to remove his most precious belongings, for another half hour he would not have escaped their fury. This plantation was quickly reduced to ashes.

"Such my dear Sir and friend, are our troubles which 
we hope have reached their acme. An appeal has been sent to your country for troops to help us destroy these brigands; but we have not much hope of receiving help. Word has also been sent to Jamaica, and to the Spaniards. We are impatiently awaiting the messenger's return and ardently wish he may bring us a satisfactory answer.

"Our safety lies in this city which is well fortified and well garrisoned.

"When the trouble began we found that our own servants, who are very numerous, would join forces with the brigands and set fire to our houses; but, by the most watchful vigilence both by day and by night, we have escaped their plots. Nevertheless a number of servants were arrested and put to death. Others that we considered suspicious were put in a safe place. As a result of this wise precaution we are now a little less anxious, and may God keep us so for many a day.

"From the beginning of the trouble there was been an embargo on all vessels in the roadstead without any distinction whatever. Our Assembly, acting in unison with the Governor-General, decided, for the present, to allow a number of American vessels that had come into the harbor to leave, and we hasten to take advantage of the departure of these vessels to send you this unfortunate news which will probably surprise you and cause anxiety concerning your business in this colony.

"We can reassure you, however, concerning the fate of your brig Polly which we suppose is still at Port-auPrince, for an embargo was declared there as well as here though the insurection of the negroes in that part of the island has not assumed such serious proportions.

"When our troubles began we had in storage about 200 barrels of flour of the Kitty's cargo, which we were forced to offer to the Province as were all other merchants 
who had any on hand. The agents of the Provincial Assembly even came and took note of the quantity; but so far no use has been made of them as the King's warehouses are full. As the requisition was made as a matter of precaution we shall continue to sell all we can to those who come to buy, lest the flour spoil. But we must remind you that there is no money in the country and we fear it will be difficult to sell the flour for cash. What gives us even more concern is when and how we shall be paid for the flour of this said cargo already sold as well as what is due on previous cargoes. Everybody is in arms and the whole country is taken up with the absorbing desire to destroy our cruel enemy, so that it is impossible to collect any money. We are afraid this state of things will continue for a long time although we are sure to come out victorious from the unfortunate condition in which we are placed. It is a most disastrous crisis for you as well as for us, and we will try to make your loss as small as possible by paying the greatest attention to your interests.

"Our M. Aubert is not in the best of health and does not seem to be able to improve in this country, and in the presence of all these calamities. As he wishes to take away his wife, for neither of them can possibly go back to their plantation, he desires to take passage for New England, leave his wife there and return himself in the spring. He will no doubt go to your city and possibly his wife will take her two children along. M. Aubert will make every effort to obtain permission to do this from our General Assembly which is at present in session here, and if granted will embark with his family sometime during the next three weeks, preferring to wait till the bad weather, which is always brought on at this season by the September equinox and is usually very severe Vol. I-9 129 
on our coast, is over. Could anything be harder for him, after spending forty years and more in a country where he made his fortune, than to see himself forced, so to speak, to flee from it and for a cause as cruel as it is amazing?"

By the first opportunity, which came the middle of October, Girard replied: "You may depend on it, my dear friend, that on the arrival of your esteemed friend, whom I have not the honor to know personally, I shall hasten to do all in my power to render him every possible service. As the house I occupy is quite large, and I keep bachelor's hall, I shall invite him to stay with me and bring all his family with him. I note that your Assembly has asked for help from this country. Provisions and ammunition will no doubt be sent, but as for regular troops, it is not to be thought of for we have only a very few and they at this moment are engaged in fighting the savages on our frontier.

"I earnestly hope you will get help from some quarter to enable you to maintain peace and tranquility in your colony.

"As for my business interests in your hands, I am not in the least worried about them, being convinced that you will look out for them as if they were your own, and that is as much as I could wish.

"Since the arrival of Captain Edger at Port-au-Prince I have received only one letter from Messrs. Patot \& Co. If they send the vessel back to me with the 60 hogsheads of sugar I have ordered I shall do a good stroke of business, as that article has gone up 5 livres, Io sous for the first quality."

M. Aubert did not sail. "The misfortunes that have overtaken us as a result of the negro insurrection of which you have probably heard, and which have not yet come to an end, as the brigands continue to ravage the country, 


\section{SAN DOMINGO AND MARSEILLES}

and are in possession of the plain as well as the mountains, had almost determined me to go to the continent with my wife and children, either to your city or to New York, there to remain until these troubles are over. But, as we have gained an advantage over the enemy on several occasions, and have succeeded in dispersing them, the city is more peaceful and appears to be safe from their attacks. I have therefore decided to stay in the hope of making this voyage in a milder season of the year. Although France is my native land the trouble prevailing in that country cannot fail to be followed by disastrous results, and I am therefore determined to choose a more peaceful land and I prefer the government and constitution of the country which you inhabit as I am in entire sympathy with the principles on which it is established and am sure it would suit me. I shall, therefore, take advantage of your kindness and ask you to help me buy an estate in one of your provinces where I could find the quiet I so much desire and where the soil and climate are good. I wish to make a purchase to the amount of fifty or sixty thousand pounds of your money, and therefore ask if you will have the kindness to inquire in advance and see if you can find a property of the sort already fully established, that is to say with a manorhouse and other buildings, with land on which the most profitable crops can be raised, near a river for convenience and greater economy of transportation, and without any encumbrances.

"After what has happened in this province but little reliance can be placed in the future in negro labor, and when these troubles are over and general safety is reestablished on whatever basis may be found convenient, many people will leave the country and go either to the continent or to Europe. 


\section{THE LIFE AND TIMES OF STEPHEN GIRARD}

"I shall keep a following, for my personal service, of several negro servants whom I believe are attached to me, both men and women. Will there be any difficulty about their being received on the continent?"

This letter was carried by Madame Sigoigne, stepdaughter of M. Aubert, who, with her child, fled from Le Cap. As to the estate, Girard suggested that nothing be done till M. Aubert arrived. As to the slaves, "that you propose to bring with you, you will have an absolute right to dispose of them as slaves for the space of six months counting from the day of your arrival in this city. After that time they will be free unless you have made some arrangement with them by which they bind themselves to serve you for a certain limited time."

Conditions in Port-au-Prince were described by $\mathrm{P}$ atot \& Co. "All the negroes are in revolt, many of them have been killed and the armed forces in pursuit of them are slaughtering them daily without suffering much loss themselves. The firm of our common friends Messrs. Aubert, Rouch \& Co. is suffering tremendous losses. We are in a very bad way here. Some of the slaves in the mountains have revolted and a number of whites have been killed in various attacks. Our position will be dreadful unless we get help promptly." Captain Edger of the Polly had been ready to sail, with 42 hogsheads of sugar, for three weeks, but when he would sail was impossible to tell, "for those who were cleared first are allowed to depart first."

"I have," said he, "Now prospeck of getin a way at present as thaire is orders that now vasels shall sail but as vasels will a rive heare $\&$ the seame to come in verey slow at presant. theaire is a great meaney ready for sea as well as my selff but the times is sow defiguilt that I canot tell what is to be Done. The Negros is burnen all 
before them and they air a feared of the town been Burned Down Evrey Nite sow that the harley dow any thing but Solger heair the Enhabetens."

October seventh the Polly was allowed to sail after paying heavy duties assessed by the Colonial Assembly and undergoing a rigorous inspection. "The rigorous inspection of American vessels practiced by officials on land, as well as by men-of-war, obliges them to truly declare their cargoes. We are extremely sorry for the injury to interests by this wanton event." On the Polly were to come as passengers Madame and M. Dartes, "a rich planter who intends to take part of his income with him to your city," Patot \& Co. wrote, "and you may suppose to your address. The illness of Madame Dartes, and the troubles existing at this time in the entire colony compel our friend to go to your city." M. Dartes did not come but sent a letter: "Just as I was about to embark with my wife on your vessel Polly for Philadelphia, in order to escape the misfortunes and calamities which affect us in this Island, obstacles and difficulties came and prevented me from carrying out my project," to go to Bordeaux, to "our native country, to the bosom of. our family and our friends." Some of his belongings he had therefore taken off the ship, a considerable portion, however, remained, including wine and coffee valued at 7649 livres. These he shipped to Girard.

When the Polly reached Philadelphia sugar had fallen to four livres, seventeen sous per hundredweight and for a time her owner was in doubt where to send her.

"The long delay of the Polly in your port," he informed Patot \& Co., "added to her expenses, and the fact that I fear she may be detained a second time, has led me to change the destination of this vessel. Another thing, gentlemen, I consider your commission rather high. 
The best firms at Le Cap always attend to my business for $5 \%$ on sales and $2 \%$ on returns, free of storage. Unless you will adopt their custom I shall not be able to do any more business with you in future." The costs while the Polly was in Port-au-Prince, and the commissions on the sugar, amounted to 7276 livres. The price of the sugar was 40,140 livres.

On her next voyage accordingly the Polly went back to Le Cap consigned to Aubert, Rouch \& Co. “As I am tired of keeping the brig Polly in idleness, and wish to renew our correspondence in such a way as to be advantageous to us," Girard explained, "I have decided to send you the vessel" with 2000 piastres gourdes and rice, flour, sugar barrels, staves, lard worth $237 \mathrm{I}$ pounds, I8s. 5 d. to be sold for cash, or exchanged for merchandise, or if a better market could be found to be consigned to some firm at Port-au-Prince. "I am not quite satisfied with Messrs. Patot \& Co.'s way of doing business. They were negligent in despatching the brig Polly, and by way of improving matters charged me with enormous costs and commission on the sugar, with the result that 42 hogsheads, the first cost of which was 40,140 livres, came to 47,416 livres, 13 sous in the invoice. In addition to these costs Messrs. Patot \& Co. had so little confidence in me that they unloaded nine hogsheads of sugar already on board the brig Polly, on the pretext that, after the events in your Island, you had instructed them to use only the funds they had belonging to me for my account. But this did not prevent their issuing their letter of credit on me for 3000 livres in favor of Mme. Dartes who came here on the Polly.

"I observe that all those who do business with your island declare only one half or one quarter of their entrance cargoes as well as of their outgoing cargoes, and I will ask you to conform to this custom as much as you can." 
December 2oth the Polly set sail, but scarcely had she gone when news came that Port-au-Prince was in ashes.

The passage of the decree of May I 5th, I79I, brought to the National Assembly a flood of petitions and addresses. They came from the commercial and manufacturing towns, set forth that the decree was sure to create a civil war between the whites and mulattoes, and declared that such a war could not fail to ruin trade and commerce with the island. Moved by this and other considerations the National Assembly on September 24th, I79I, repealed the decree of May I 5 th, left the treatment of mulattoes and slaves in the care of Colonial Assemblies, made this decree an article of the French Constitution, and sent three Civil Commissioners to San Domingo.

The determination of the whites that the decree of May $15^{\text {th }}$ should never be executed, was followed in August by the gathering of the mulattoes in the West and especially in the Artibonite. But conditions which need not be described led the two parties to form an alliance known as the "Confederation of La Croix-desBouquets." Alarmed at this action the mob rulers of Port-au-Prince determined to strike at once. To that city had come in March of I79I a squadron carrying two regiments of French troops. They were sent to restore order and uphold the authority of the King, but quickly joined with the mob, forced Governor Blanchelande to flee to Le Cap, murdered Mauduit and aided in setting up a mob government. This the town merchants dared not resist; but when the democrats of Port-au-Prince early in September marched against the Confederates at La Croix-des-Bouquets, and were ambushed and cut to pieces, the whites in the city formed with the Confederates the "Concordat of September," and bound themselves not to resist the Decree of May I 5 th. 


\section{THE LIFE AND TIMES OF STEPHEN GIRARD}

When news came that this Decree had been repealed the mulattoes in Port-au-Prince demanded that the whites should hold to the Concordat, and when, in November, the question was put to popular vote a riot arose, a pitched battle followed, the mulattoes were driven from the town and a great part of Port-au-Prince was laid in ashes. The town was then besieged by the mulattoes and the country round about laid waste.

"I sincerely hope," Girard wrote to Aubert, Rouch $\&$ Co. when he heard of the burning of Port-au-Prince, "that your Government will have the wisdom to preserve your city from a similar misfortune.

"I presume that after the calamity at Port-au-Prince you have kept my vessel in your harbor and will there sell her cargo. In that case I cannot too strongly urge you, gentlemen, to sell my cargo for cash or in exchange for commodities, and dispatch her promptly, taking care to send me by her return the net proceeds of her outgoing cargo and the 2000 piastre gourdes, one third in raw sugar of the finest quality you can procure; one third in thick red syrup; and the remaining third in trade coffee. If you cannot get syrup invest my funds in sugar and coffee. If you are unable to dispose of the 80 firkins of lard before the brig Polly leaves your port at I $4 \mathrm{~d}$. per pound or more, for cash, or in exchange for commodities, you will please send them back to me by the return of the said vessel.

"The news from Port-au-Prince has caused a rise of about $10 \%$ in the price of sugar and coffee although it has not increased the demand for these articles. If there is an embargo at Le Cap and you can get permission for the brig Polly to leave, on condition that she will return to you at once with flour, \&c., or even gun powder, if they demand such a condition, you may make any con- 


\section{SAN DOMINGO AND MARSEILLES}

tract of that kind on my account and I will take care of the rest."

When the Polly reached Le Cap, the voyage to Portau-Prince was abandoned, much to the regret of Patot \& Co. who said, Messrs. Aubert, Rouch \& Co. decided to keep the Polly in their city, fearing, no doubt, that the cargo would be seized at Port-au-Prince and paid for in drafts on France as had been done in the case of other cargoes. "The misfortunes that have befallen our unhappy city have prevented us from receiving any commodities for the last three months, as we are still at war with the negroes who hold the plain and the hills."

Some of the flour was sold at Le Cap for six gourdes per barrel, and some of the rice for four gourdes per quintal. The rest was held, Aubert \& Co. explained, for a rising market.

"As we are confidently expecting to receive French troops at any moment we believe flour will go up on account of increased consumption which will be very great and will be increased even more when exportation to the eastern and southern portions of the Island is permitted, as those regions have, like ourselves, suffered from fire.

"We shall not entertain you at length with the motives which have led us to keep your brigantine here rather than send her to Port-au-Prince. The misfortunes under which that city is still staggering as a result of the fire which consumed more than 300 houses, made us give up the idea of sending your vessel there. All the merchants and many of the citizens are obliged to stay on board the vessels in the roadstead which is their only place of refuge. We fear that tranquility will not be restored there for some time, indeed, not until they have men enough to overcome the mulatto brigands whose chiefs 


\section{THE LIFE AND TIMES OF STEPHEN GIRARD}

are white men whose names have been given to our Colonial Assembly. In our own city we have prevented such a state of affairs by our great vigilence, which will always frustrate any conspiracies among the mulattoes we may have in our midst."

When at last the cargo was sold the proceeds amounted to 38,224 livres, 9 sous. Of the amount of sales of cargoes brought by the Kitty and Polly on former voyages there remained uncollected 54,497 livres, I sou, 7 deniers, but, because of advances made by Aubert, Rouch \& Co. for the purchase of return cargoes Girard owed them 49,682 livres, 6 sous, I denier. "If," they explained, "it had not been for the misfortunes that we have recently suffered, the debtors for the cargoes of your vessels, save two or three, would not have been in arrears because we are exceedingly careful about placing our goods. But even the richest people in the city cannot escape falling behindhand because of the enormous losses they have suffered. Your debtors are mostly brokers whose business has necessarily been affected by the condition of affairs. As soon as the troops we expect, some of whom have already arrived, get here, business will resume its usual course and we shall not fail to take advantage of every means to collect what is owing to you on your cargoes."

The course of events in France meantime had made Girard anxious for the safety of La Virginie. She had sailed in March I79I and after a voyage of seven weeks arrived at Marseilles, whence Samatan sent back the agreeable news that the Fermiers Généraux had been abolished.

"The abolition of the Fermiers Généraux which makes it possible for any one to manufacture tobacco, has increased the competition among buyers and we must there- 


\section{SAN DOMINGO AND MARSEILLES}

fore take advantage of the present moment. It will be a long while before enough of the plant is cultivated in France to supply the certain demand and it is therefore assumed that we shall no longer have the law laid down to us by a single buyer, but that our turn has come to dictate terms. A number of large factories are to be built. Several manufacturers have already asked me whether I would undertake to furnish a certain quantity on a several years' contract. Let me know whether you care to undertake to furnish a certain quantity per year, at what price and for how many years I might contract either for your account or on shares.

"I am now engaged in suing the owner of the warehouses which collapsed, for the damages resulting from the loss of 52 charges of wheat, for the lessened value of ro3o charges which were recovered, for the heavy cost of recovering the wheat and various sums which the judges ordered me to pay, provisionally, to the widows of the poor workmen who were buried under the ruins. As the report of the experts appointed to examine the construction of these warehouses proves they were not built according to police regulations I hope the suit will be decided in your favor. Justice, however, is so slow and our courts so feeble in these days of revolution that I cannot tell when the suit will be decided."

While these two letters from Samatan were still on their way to Philadelphia, Girard, hearing nothing from Samatan, lost his patience and September third wrote: "As I am still without news from you, I infer that my business is not of sufficient importance to merit your attention. I have therefore decided to consign a small vessel and her cargo to Messrs. Daniel Cornaz \& Co. of your city.

"I shall not attempt to conceal from you, my Dear 
Sir, that I am very sorry that I am obliged to enter into business relations with another firm; but it will not prevent me from despatching to you, after she arrives here, the brig La Virginie with a cargo of tobacco part of which has already been bought from Messrs. William \& James Douglas of Petersburg."

The small vessel sent to Cornaz \& Co. was the Kitty. The value of her cargo of tobacco, iron hoops, whalebone and coffee was $£_{3234} 4$ s. $2 d$. Pennsylvania money or $8757^{-78} / 90$ piastre fortes or dollars. "As I am afraid the introduction of coffee into Marseilles will not be permitted, I have thought it wise to send the said brig Kitty to Nice with orders to put into Marseilles so as to enable you to send the coffee to Nice to be sold there in case you cannot unload it in your port." The return cargo was to be sulphur in sticks, verdigris in tablets, unspun oakum and Cette brandy, to get which the Kitty was to be sent to Cette. "Although I have a high opinion of my Captain and vessel, I am always glad to escape a risk, and therefore ask you to place an insurance for my account against all risks, with good insurers of your city, equivalent to the amount of the invoice of merchandise for the return voyage less 22,000 livres tournois as I have that sum placed here against all risk for the outgoing and return voyages. In addition to this sum of 22000 livres I have taken an insurance of 8800 livres tournois on the vessel against all sea risks which together make 30800 livres tournois. I am exposed to dangers from the Algerines, and other Turkish and Barbary tribes. I pray you insure to the same amount against the risks from Algerines, Turks and Barbary pirates. Try your best to place the insurance for a premium of $1 \%$ including all costs. You will call the attention of the insurers to the fact that the brig Kitty sails under the American flag, that 


\section{SAN DOMINGO AND MARSEILLES}

she is copper sheathed, well equipped, carries some guns, is well supplied with sails, and that the Captain has in his possession a counterfeit English passport."

Scarcely had the Kitty set sail when Girard received the letter from Samatan dated July sixth. All hard feeling at once subsided at the prospect of a tobacco contract. "I should be delighted," he promptly replied, "to take an interest with you in a tobacco contract." But to negotiate French drafts was so difficult, and as business paper might easily so depreciate as to cause heavy loss, he would not enter into such a contract unless the price of tobacco was fixed in pounds sterling, payable in London, or in Spanish money payable in Cadiz. "On these conditions you may make a contract on equal shares with me to the amount of 8000 hogsheads to be delivered on the scales in Marseilles or any other French port within four years, that is to say, 2000 hogsheads per year.

"Good Virginia tobacco suitable for your manufacture will probably cost 18 shillings, Virginia money, per hundredweight on the ground; but it is better to calculate on the basis of 20 shillings which corresponds to $31 / 3$ piastres fortes. To this must be added 2 piastres fortes per hogshead for duty, carting and transportation to the vessel, besides the commission to be paid for the work which I can get for $2 \mathrm{~T} / 2$ per cent.

"When you make your calculations remember that our weight of 100 pounds corresponds to 92 pounds marc which, added to the fact that tobacco in hogsheads shrinks about 5 to Io per cent., makes a further loss of about 5 per cent. due to the tare on the hogsheads because the planter allows only the weight of the hogshead for tare and the hogsheads are verified and weighed when the tobacco is inspected. This makes about Io per cent. on 
the gross weight, and in Marseilles you allow 15 per cent.

"If this contract is made you will have to begin by chartering two or three good French vessels which you will send to Norfolk, in Virginia, with orders to deliver my letters to Mr. Moses Myers, merchant in that place, who will give instructions to the captains where to go for the cargoes"

Not a French vessel was in the Delaware nor was it at any time easy to find one for charter. As for Americans, he did not believe that an offer of twenty piastre fortes per hogshead would induce any owner to send his vessel to Marseilles. "You will have gathered from my last letter that I am sorry to have consigned my brig Kitty to another firm. I repeat, my dear sir, that $I$ am very sorry that your absence and the failure of your house to keep me informed forced me to take this step; but let us hope that we shall make up for lost time and recoup ourselves for past losses by cultivating our correspondence more assiduously than we have done recently."

About the time Samatan was writing his July letter, Girard's new correspondent at Marseilles, Daniel Cornaz \& Co., sent him prices current and news of the political condition in France.

"You have probably already heard that our King, displeased with the new constitution, made an attempt on June 2ist to leave the Kingdom. He was arrested on the way and brought back to Paris, and this proceeding which might have shaken the empire to its foundation, has not in the least disturbed public order and tranquility. Business goes on practically as before. The power of the King, as the chief executive, has been suspended and is provisionally exercised by his minister. The National Assembly is occupied with such measures as this event makes necessary. For the future it waits till public opinion declares itself; but at present it is still 
unformed. Nevertheless the constitution goes on without interruption and will soon be finished, and we know of nothing, either within the Kingdom or abroad, to justify any well grounded fear."

Late in October the Kitty arrived safely at Marseilles to find a poor market for her cargo and high prices for the goods she was to bring home. "As coffee from your country is not allowed to enter this harbor you should have given out," Cornaz \& Co. wrote, "that it had come from the salvage of a French vessel. We are trying to have your 225 quarter barrels considered in that light so as to make it possible to bring it into the harbor. If we do not succeed we shall sell it on board the brig for Trieste or the Levant and have it trans-shipped at once. This will be a much better plan than sending it to Nice which is too small a market for such a purpose and where your coffee would sell very slowly and at poor prices." Even if they did give out that the coffee was obtained from the salvage of a French vessel and was admitted to the harbor it would be subject to a duty of $3 \%$ ad valorem and another of 25 livres per quintal. By selling without unloading no duty whatever was paid. "As for the tobacco, such a large quantity, as we told you, has come here that the market is very quiet and we shall be obliged to put your 66 hogsheads in storage. The $\mathrm{Na}$ tional Assembly having forbidden the transportation of tobacco through the Kingdom, we are cut off from the market we might have had in Geneva and Switzerland; but we have written to Genoa and Venice asking whether tobacco could be sold there to better advantage than here, where it sells at 25 livres a quintal marc with prospect of a fall."

Wheat was the best article for shipment from America, for fine American "is worth at the present moment from 
36 to 38 livres without any appearance of going down, so that you might count on selling at 36 livres."

The coffee was finally sold at 15 and $16 d$. per pound, because the fact that it could not be landed "forced us to shade the price a little. As we could sell neither to speculators nor to consumers we had to find buyers who were in a position to ship the goods abroad at once." Scarcely were the sales made when news of the negro uprising in San Domingo arrived and the price of coffee rose at once. "A man with power to foresee the future could have made in fifteen days a fortune such as usually requires the labor of many long years. But, as it was not possible to foresee such an unexpected revolution, we have at least the consolation of having sold your coffee as well as the state of the market permitted. Could it have been landed and stored it would perhaps have come in for its share in the subsequent rise but as we were limited to purchasers who could transship it directly, and had your orders to hurry the return of your vessel, we were unable to do any better."

The tobacco was finally sold at 42 livres per quintal, and the Kitty made ready for her voyage to Cette, where the brandy she was to bring home awaited her; but for more than a month she was unable to leave the harbor. "By the most unusual ill luck, bad weather has continued so steadily that the Captain has been prevented from getting to Cette. Captain Moore left this harbor four times only to return each time. Once, it is true, he failed to get out because of lack of courage on the part of the pilot. But another time it was just as well he did return as otherwise he would have gone to the bottom, as did another vessel."

While the Kitty was still at Marseilles La Virginie, consigned to Samatan, came in with 240 hogsheads of 
tobacco, 120 whalebones and 14,046 staves. Commanded by Captain Pierre Demay she sailed from Marseilles on the sixth of July, reached Philadelphia in September, was sent to Petersburg for tobacco and from there, went directly back to Marseilles. Coffee had by that time risen to 33 sous per pound and raw sugar to 150 livres per quintal. "Sugar and coffee," Samatan wrote, "have been forced up to extravagant prices; but there are reasons other than the troubles in San Domingo. All our commodities have risen in price from 30 to $35 \%$ in proportion to the depreciation of our paper money."

January 1792 the Kitty with fifty other vessels set sail from Marseilles. The proceeds of her cargo was 61,953 livres, 16 sous, 6 deniers, and the value of that she was to carry home including the brandy to be taken on at Cette 64,270 livres, 17 sous 6 deniers. The net proceeds of the cargo of La Virginie was I I4,257 livres 7 sous. Late in January the Kitty arrived at Cette, and before the month ended was on her way to Philadelphia. A fortnight later La Virginie followed her.

From Le Cap where, at the close of January, the Polly was awaiting her cargo came word that raw sugar was selling at 90 livres. "The rise in the price is due," Aubert, Rouch \& Co. wrote, "to the fires started by the brigands in the Province of Fort Dauphin which could otherwise have sent us a large supply. As long as the price of sugar is what it is we must not think of buying the quantity you want; nor can we buy coffee the price of which is much higher than your limit." The Polly had taken instructions to Aubert, Rouch \& Co. to charter, if possible, a vessel to go to Petersburg for tobacco. After some difficulty because of high freight charges, I Io livres per hogshead, they finally "succeeded in inducing Captain Sauvage of the ship Le Courrier du Cap "to sign the

Vol. I-10 
charter party for the vessel at the rate of 50 livres tournois per hogshead." She was from Nantes, had a capacity of 400 hogsheads and as this was larger than Girard desired he was requested to buy 100 hogshead of Virginia tobacco for the account of Messrs. Daniel Cornaz $\&$ Co. and ship them by Le Courrier du Cap, which was then at Port-au-Prince. The value of the sugar and coffee sent back by the Polly was 58,095 livres, 2 sous, 9 deniers.

As time passed and nothing was heard of Captain Sauvage, Girard grew anxious, for no sooner did he receive word of the chartering of Le Courrier du Cap than 300 hogsheads of tobacco were ordered. Again and again he wrote to Aubert, Rouch \& Co. asking what had become of her. "If for any reason, this vessel is prevented from sailing on this voyage, which you can easily find out, charter another one for the same voyage and send her to Petersburg for the tobacco intended for the first." "You tell me nothing of the ship Le Courrier du Cap. As I have given orders in advance for the cargo she will not make a long stay in Virginia. But, if Captain Sauvage has changed the destination of the vessel it will cause me great embarrassment, as I see no possibility of securing a French ship to carry this shipment of tobacco." "If the Captain of this vessel has changed his mind as to the voyage he agreed to make for me, I pray you make him pay the entire forfeit and consign to me another vessel." When April came and the vessel had not arrived at Petersburg he wrote: "The last letter I received from Messrs. William \& James Douglas is dated the sixth instant and at that time the ship Le Courrier $d u$ Cap had not arrived in Virginia. It is to be presumed that the Captain changed the destination of the vessel and in that case he has done me a grievous wrong as I stripped myself of 
funds I needed badly in order to buy the tobacco for the voyage."

At last, Aubert, Rouch \& Co. reported. "We received yesterday the disagreeable news that Captain Sauvage, commanding the ship Le Courrier du Cap, which we informed you we chartered, is still at Léogane and does not seem to have any intention to make the voyage as he agreed to do. Since the twentieth of March he has been looking for freight to Nantes. On receiving this news, which we cannot but regard as correct, especially as the Captain ought to have left on the fifth of March, we at once looked around for another vessel and found one. The clauses and conditions of the Charter party are the same, but as Captain Charpentier, commanding the ship Les Citoyens de Paris, of Le Havre, which is the vessel we have chartered, came here with troops and brought nothing convertible into money, and as he sees he will need some we have willingly consented, in order not to miss so good an opportunity of replacing Le Courrier $d u C a p$, to give him our order on Messrs. William \& James Douglas of Petersburg for the sum of 1650 livres equal to 200 gourdes."

Of the flour which Girard had sent they had sold 284 barrels at 7 gourdes or 57 livres, 15 sous, for the depreciation of the assignats had raised the value of the gourde to 8 livres, 5 sous, and 244 barrels at from 53 livres, I 2 sous to 56 livres.

And now they proposed to Girard a government contract. "The administration," they wrote in January, "is busy supplying the colonies with flour, salt beef and pork, but offers to pay in drafts on the French treasury as it cannot give cash which still continues scarce. We have not been able to agree to furnish supplies in return for such paper because it is not current in your country 
unless Congress is willing to take it. It seems certain that these drafts at six months from sight on Boutin, Treasurer General of the National Treasury at Paris, will be duly paid, since the National Assembly, as soon as the news of our misfortunes was received, voted $20,000,000$ livres to be used in sending us aid, and the merchants of France who have a strong interest in preserving this rich colony will not fail to pay this sum into the Treasury.

"The quantity to be supplied each month is 2000 barrels of flour, and 300 barrels of salt beef and pork. With the great resources you have at your command you could easily undertake this contract, if you could be sure of being paid in silver or of selling the draft in your market. Let us know what you think about the matter that we may conform to your instructions, and tell us at what prices you could furnish the articles."

The terms offered for payment did not suit him. Nevertheless he consulted M. de la Foret, the French Vice-Consul General, who told him that "one could not count on the drafts drawn by your Government and Colonial Assembly on him, or on Congress, for French flour \&c.; that as the States have granted a certain sum of money they have thereby shown they could do no more, and that, through the agency of the Commissioners you sent here arrangements have been made to dispose of these funds as fast as they are received. As the consul adds that he has informed your government about these arrangements you are in a position to judge from the drafts, \&c., that have been drawn on him whether he has funds enough remaining to honor any engagements your government may assume.

"If you find that he has, I will ask you to make a contract for my account for 8000 or 10000 barrels of 
superfine flour, to be delivered at Le Cap at certain stated periods till September next, the price to be ro pastre gourdes per barrel payable one half in forty-five days from sight, in drafts on the French Consul or any other in Philadelphia, and the other half in drafts at six months on the French Treasury. One-quarter of the former (short term drafts) to be delivered at the time of signing the contract and at subsequent periods thereto in advance of each delivery, so that, if the drafts are protested, \&c., the contract be thereby annulled.

"If they prefer to make a contract with you for drafts on Philadelphia, you may also make it for my account for 15000 or 20000 barrels, but not at less than $71 / 2$ piastre gourdes a barrel, in every instance payable in advance at 45 days from sight."

These fine hopes of a profitable speculation were quickly dashed by a letter from Thellusson Bros. \& Co. of London: "In France things are going from bad to worse. The present National Assembly, which is in every sense worse than the last, is doing ten times as much harm. Civil war is regarded as inevitable. For our part we believe it will be short. People are tired of seeing harm done without any good resulting therefrom."

The moment this was received, Girard wrote Aubert, Rouch \& Co.: "It appears that paper money is depreciating daily in France, a circumstance that makes me less willing to furnish your government with flour, payable in drafts on the treasury. If, however, you have made a contract to furnish flour for my account, you may depend on it that I will carry it out; but if not, do not make any contract with the proviso to receive part of the payment in drafts on France." The reply was: "As $M$. de Foret has advised our Intendant that he has shiped 6000 barrels of flour, \&c., the latter cannot make any 
new contracts until further orders. If we had made or should be able to make in the future any contracts with the Administration for provisions, it is our intention not to accept any drafts on France if possible. After what you tell us we shall absolutely refuse to accept any drafts but those on Philadelphia if we make any such contract."

A year and more had passed since Girard heard from Bordeaux concerning the settlement of the estate of his father when, one day in the spring of 1792 , a joint letter from his sister Victoire and his aunt Lafargue informed him they were penniless. Such was their straits that, although advised not to do so, they were forced to appeal to him for help. He would do, he promptly replied, all in his power to help them.

"But first of all I must ask you for the name of the person who gave you the good advice not to write to me, and the details concerning the affairs of the family. I am surprised that M. Gaube, of your city, has not furnished you the help your position requires. I wrote that gentleman asking him to withdraw my maternal and paternal claims and to use my interests for the benefit of my sister Victoire until further orders from me. His silence makes me suspect he has other interests in view. I shall set about finding means of sending you money; on that you may depend. Meanwhile write me in duplicate.

"P.S. I am like yourself, without news from Mombrun (Jean Girard) and I cannot deny that the unworthy conduct he has shown towards me has made me resolve not to think of him any longer. I shall say about him what my late father said-that he is a worthless fellow who is not to be trusted. I tell you this in confidence between you, Mombrun and myself. You may tell him what I said if you ever see him, I think it likely that in about a month after you receive my letter you will get some assistance." 
M. Samatan was then asked for the address of a good firm in Bordeaux and for a letter of recommendation to them. "I wish to find some one to settle my family affairs and as I shall have to begin by spending some money will you have the kindness at the same time to open an account for me in that city for from ten to twenty thousand livres tournois.

"Will you have the kindness to pay at once for my account, through your correspondent at Bordeaux, fifteen hundred livres tournois to the Misses Lafargue and Victoire Girard living in Chartrons.

"M. Sauvage, also living in Chartrons, will tell your correspondent where they live. They are relatives of mine who tell me they are in straits."

Small as was the pittance, it was thankfully received and brought a grateful letter of acknowledgment.

"It is very unfortunate for us that we waited so long and continued in want. When M. Louvrier told me by word of mouth that Mombrun could not continue his bounty to me, I said that we ought to write to our elder brother. 'No, by Heavens,' said he, 'they have quarreled.' I did not know what to do. I made known my plan to M. Dody and told him M. Louvrier's answer. He was surprised and said to me: 'I know not what to say to you: your position is cruel; lawyers all stand by one another.' Victoire wants her rights: but Sophie and Gaube are very shrewd and have done well at your expense and Victoire's. Gaube has built, since he took charge of this business, and Sophie has built at Quinsac (Cubzac). It is clear that her property has been kept separate from that of her husband, and that everything is done for Fénélon. Although he has failed twice, they have been at their ease since father died. Mombrun has been deceived by Sophie. The Jacobin, Gaube, has 
done great injury to Victoire. *** She has been cheated on every hand and reduced to eating dry bread part of the year." "Oh, my dear Sir, what relief in body and mind you have brought us both. All we can do is to beg you to continue your kindness; we shall not fail to deserve it. ${ }^{* * *}$ Gaube and Sophie have been spending money freely, and are enjoying everything and it is very evident they have spent quite a sum in repairs and that everything has melted away. If you cannot come to France yourself you ought to send some trustworthy man to straighten out this business, or else have somebody give you an account of Victoire's claims, then give her a life pension suitable to her infirm condition. We are both being cheated, and that is why I ask you to come, dear sir, or commission some honest person to act for you and for Victoire, as soon as possible. We are reduced to a pitiable condition of misery."

Girard at once recalled the power of attorney given Gaube, appointed Dierx, Bourgailh \& Co., or either of them, his "general and special attorneys" to act for him in the settlement of the estate, sent it off to Bordeaux, and briefly stated the facts in the case.

"My father died in Bordeaux several years ago, and made me his heir. M. Gaube of your city, who merely had my power of attorney to represent me in the matter of my maternal rights, took it upon himself to repudiate, as he says, the inheritance of my late father under the pretext that he feared the debts would absorb the estate.

"By virtue of my power of attorney which I enclose, I will ask you, gentlemen, to make a thorough investigation of this matter and, after consulting two good lawyers, to represent me in my capacity of heir and demand an account of everything belonging to my said father's estate. 
"You will also kindly represent me for my maternal rights which consist of a fifth share of the sum of 50,088 livres awarded to the five children of the first marriage of whom I am the oldest.

"I have my sister Victoire who lives aux Chartrons with my aunt Anne Lafargue, and as they recently sent me word they were in want I gave them some help. If they are still in want $I$ will ask you to give them an allowance for my account, until further orders from me, of one thousand livres tournois payable in quarterly instalments. It is understood, of course, that my sister Victoire will co-operate with you in suing for our family rights, and in that case I will ask you to look after her interests as if they were mine." Messrs. Dierx, Bourgailh \& Co. were further requested to pay his old creditors, six in number, the amount due each, without interest.

"I asked M. Gaube to pay these creditors, but he answered me that several of them to whom he had spoken about it demanded interest, which could not be just, as I never refused to pay them, and since I came here requested them to send their power of attorney so that I might settle with their representatives.

"You will kindly draw on M. Samatan, of Marseilles, for the amount of your expenditures and send me your account.

"My deceased father had a property at Tresse belonging in part to the children of his second marriage. If this is still in the family and can be had for a moderate price I should be glad to buy it."

The letter of Girard to his aunt and sister stating his resolve not to think of his brother any longer had scarcely been written when one from Jean came to hand. Alarmed by the state of affairs at Le Cap and at Port- 
au-Prince, and discouraged by losses, he had left San Domingo, gone to New London, Connecticut, and would come to Philadelphia, and asked what articles were suitable for the market in that city.

The old quarrel was at once forgotten, and Girard replied: "I received your letter of the fifth instant informing me of your intention to come to Philadelphia. I desire to be useful to you, and help you recoup yourself for the losses you have suffered. I have no time to find out what articles from your part of the country are suitable for this market, but should not suppose they would be very profitable." Thus made welcome, Jean came to Philadelphia where the old friendship between the brothers was renewed.

While La Virginie was preparing to depart for Marseilles, news reached our country that the King of France driven on by the National Assembly had declared war on the Emperor of Austria.

Sure that neutrals would not be molested Girard felt no anxiety for the safety of his ships under the American flag, but for the safety of La Virginie and Les Citoyens de Paris, both under that of France, he was much alarmed, and for a while thought of hurrying to Norfolk and putting La Virginie under the American flag, and wrote to the Petersburg firm to hold her if possible. "The declaration of war between France and the Emperor of Germany gives me a great deal of uneasiness concerning my shipments in French bottoms. Therefore, should the brig Virginie be in your river, or at Norfolk, please request Captain Demay to stay in this last port till further advice from me. In this last case I beg you will let me know of it by express and her port, immediately, so I may go down without delay to do the necessary."

Captain Demay was instructed: "In view of the 


\section{SAN DOMINGO AND MARSEILLES}

rumor of war that has spread abroad here I wrote Messrs. William \& James Douglas on the 25 th of the month (June) to tell you to stay in Norfolk with your vessel until you heard from me again. My intention then was to join you and if possible put La Virginie under the American flag. But, remembering that $I$ had an old American passport of the brig La Virginie, and as neither my health nor my businsss allows me to absent myself from Philadelphia, I looked for the said passport, found it among my papers, and send it to you enclosed herein. It will be enough in case of war. All you need do is, get a little American flag, and use both, if necessary, with a great deal of prudence.

"The latest tidings from France under date of the third of May, inform us that the war is entirely between France and Germany and that Spain does not appear to show any disposition to take part in it, as she fears for the peace of her own kingdom, the Catalonians having made several threatening advances. We are also assured that I 50,000 French patriots have invaded Germany and attacked Ostend. If this news be true, it is to be hoped peace has been restored by this time. During your voyage from Norfolk to Marseilles, keep away as much as possible, from the latitudes infested by the Corsairs as their visits are never agreeable. I am also of the opinion that you had better make land at Cape Spartel and from there hug the Barbary Coast to a point 20 miles east of Minorca when you will be able to cross, avoiding the coast of Spain as much as possible. I make these suggestions to you as an old sailor, and not at all for your guidance.

"If you meet any vessels on the high seas do not show your colors till you are sure of the stranger's nationality. If she is not French and belongs to any power at 
war with France show your American passport, in short, do the best you can in the emergency."

Satisfied that the old passport would give ample protection "and finding that the last news from France was more favorable," Messrs. William \& James Douglas were requested to forward his letter to Captain Demay and bid him "set off as soon as possible for Marseilles." July twelfth he was still at Norfolk, but hoped "to put to sea the day after to-morrow unless I am prevented by the Consul whom I expect to see in order to ask him whether I run any risks because of the war existing between France and the King of Hungary and Bohemia. The said consul probably has instructions from the Minister of the Navy in such a case."

Samatan, to whom La Virginie was consigned, was told: "We have received the sad news of the declaration of war between France and the Emperor. If these tidings are true and the brig $\mathrm{La}$ Virginie arrives safely in France, do not let it prevent your sending her back to me at once with all the articles I ordered in my letter of the $7^{\text {th }}$ inst.

"I am of the opinion that in case of war you would better have La Virginie under convoy, if you can get one without delaying her departure too much, as far as the Narrows. * * You ought to know that in the charter party of the ship Les Citoyens de Paris, Captain Charpentier, it is stated that in case of war, hostilities or reprisals, the captain may act according to his judgment and may save his vessel and cargo by taking her into the nearest and most frequented commercial port in France. If it be in the Mediterranean, directly to Marseilles; if it be in the Atlantic, into Bordeaux, Nantes, or Le Havre, and he is at the same time to notify the consignees. As for the brig La Virginie the Captain simply has orders to go to Marseilles." 


\section{SAN DOMINGO AND MARSEILLES}

Messrs. Thellusson Bros. \& Co. of London were instructed to procure insurance. "We have received the sad news of the declaration of war between France and the Emperor. Do not let this occurrence, I beg of you, keep you from placing the insurance I took the liberty to ask you to effect for my account both on the French brig La Virginie and her cargo, and on the tobacco on board the vessel; also the French sloop Les Citoyens de Paris." The insurance was to be for $£_{1} 000$ sterling on the hull and rigging of La Virginie; £1000 sterling on the tobacco on board, and $£_{1500}$ sterling on the tobacco for his account on Les Citoyens de Paris. "You should be informed, gentlemen, that in addition to the insurance I am asking you to place in your city, I have insured in this city $£_{1000}$ of our money on the tobacco on La Virginie and $£ 2000$, also of our money, on the tobacco on the ship Les Citoyens de Paris for the outward voyage at $3 \%$ premium."

Having thus protected himself against possible loss as best he could he turned his attention to the San Domingo trade and wrote for news from that sorely troubled island.

"There is a rumor here that your assembly has passed a decree in favor of the black people and that it will restore quiet for the moment in your colony by sending the slaves back to their duty. If this is the case you will do me a favor if you will let me know the effect of the decree as I have no faith in the news that reaches me from your Island, and your advices will always guide me in carrying out my operations with your island." The Kitty was at the wharf and would stay there till he got more encouraging news.

"By a decree of the National Assembly," was the reply, "passed on the 24th of last March and sanctioned 
by the King of the $4^{\text {th }}$ of April, following, the mulattoes and free negroes have been given equal rights with the whites, and our Colonial Assembly has been forced to conform to this decree. The Governor has just left for St. Marc and the neighboring country to satisfy himself if he may count on the fidelity of these people and the coöperation of their forces with the whites in a general attack which he proposes to make before long against the brigands. If the attack is successful, as we have reason to expect, peace, so desirable, may be restored to our island."

July first the Polly reached Le Cap. Aubert, Chauveau $\&$ Bacon, successors to the old firm, were informed that the value of the cargo was $£_{1502}, 5 s .6 d$., Pennsylvania money. Unless they could sell the flour for a gourde a barrel more than was given for such as came every day to their port, and the pork for 16 gourdes a barrel, they were to send the Kitty to Port-au-Prince, sell the cargo there and load with raw sugar, coffee and syrup. If affairs had "resumed their former course at Le Cap, or you have reason to expect a change for the better, let me know, as your advice may possibly encourage me to buy another vessel, and add it to the brigs Kitty and Polly, so as to have all three vessels engaged in the trade between Philadelphia and Le Cap."

"We think we may reassure you," was the reply, "by : telling you that the war now going on in France with the Emperor cannot harm our commerce as the Minister has provided men-of-war to cruise about all the ports of France, England, and Spain, to maintain neutrality in this emergency. We have to fear only Jersey and Guernsey now under the Imperial flag in the west, and the Algerines and other pirates in the Mediterranean; but we know that frigates are cruising in these waters." 
"Many of the planters who have taken refuge here are going back, as we hear peace is beginning to be restored in the chief cities of the colony through which the General has just passed. We are expecting his return. The decree of the National Assembly, March 24th, to which the population submitted, but not without a murmur, has had the effect of bringing back the colored people. The bait held out to induce them to return shows a scandalous disregard of our color. This is a time of revolution, and breeds many extravagances. If men would only attend to their own affairs things would be much better. I hope that after the events in the west and south, where peace and tranquility are not even yet restored, we shall have our turn as well. The impending arrival of a convoy with troops, which, judging from advices just received, must have left France about the end of June, will soon give us the rest we need so badly. Some difficulties will probably be encountered in reducing the rebels in the mountains, but if we can get the chiefs in our power, or destroy them, the rest will not hold out long. The plantation owners will then return to their homes and there will be an active demand for commodities of every kind."

M. Aubert still held to his plan to go to America, "I do not," he said, "believe the French nation is destined to enjoy a long peace. I shall therefore be forced to leave whether I want to or not, and go to some place where men are wiser and content with what they have, without trying to lift themselves above what they ought to be. You will soon have a good many emigrants who will swell the numbers of your inhabitants as many will settle permanently and this will perhaps be a greater revolution than that of the Edict of Nantes."

The decree of March 24th, 1792, mentioned by M. 159 
Aubert, ordered that immediately after publication, the inhabitants of each of the French colonies of the Windward and Leeward Islands should proceed to the election of Colonial and Parochial Assemblies according to the mode prescribed in the decree of March 8th, 1790. At these elections the mulattoes and free negroes were to vote and be eligible to seats in the assemblies; and three civil commissioners were to be sent to San Domingo, and four to the islands of Martinique, Guadeloupe, St. Lucia, and Tobago to see that the law was properly enforced. These commissioners were to establish union, order and peace, discover and send to France the authors of the troubles in San Domingo, and call forth the public forces when necessary to execute their orders.

Political affairs on the island, save when they affected trade, gave little concern to Girard. As an Antifederalist his sympathy was with the French in their struggle for the Rights of Man, and he saw in the new Decree nothing but good. The assurances of M. Aubert that peace was being restored to the chief cities, that the planters were returning to their homes, that the negroes were coming back to work, that troops were on their way from France, were most encouraging and led him to carry out the plan to add to his fleet. In September, therefore, he was able to inform M. Aubert, "I have just bought a half interest in Captain John Cochran's beautiful and excellent brig (the Sally) and shall send her to you under command of the said Captain, loaded with brandy and flour. The Captain's brig has a capacity of about 400 barrels of flour and she has a very fine cabin which is fitted up like that of a packet boat. You will oblige me if you will engage all the freight and passengers you can, in advance for the vessel. If any of your friends wish to come to the continent they could not find a better opportunity." 
She was to sail in September and Jean Girard, still at New London, was urged to go on her to Le Cap and settle his affairs. But he could not make up his mind what to do. For a while he thought of buying a little house in Wethersfield; and then of coming to Philadelphia, and asked his brother "To rent a pretty and respectable little house," if possible, "near Cochran, as the houses are cheap in that quarter, or elsewhere. I should prefer one with a garden around it." Girard refused to find him a house for, said he, "you must know very well I do not care to mix in your domestic affairs." Then he thought of New York.

"For many reasons, needless to repeat here, I ought to have asked your advice and found out from you whether it would be better for me to settle in New York, and in what line of business. I must work, and shall need advice; but who will give it to me in that place? Philadelphia would suit me very well in one way but not in others, as I remember the time when I was engaged in business there with a very respectable capital, whereas now my means are very slender and shall have to serve my apprenticeship. Oh! Revolution! How many reasons have I for cursing it."

"I can only repeat what I have already told you," was the answer. "If San Domingo is lost, which I find very hard to believe, you must forget it and settle in whatever place suits you best. But, if you still think you have any resources in that island, or any prospects of recovering the remains of what property you left there, you must settle your family wherever it suits you best, very inexpensively, and leave for Le Cap at once. Captain Cochran expects to sail for San Domingo about the I 2 th inst. (September) and with the idea of helping you I have taken a half interest in his vessel. I will not charge

Vol. I-11 
you any passage money and though I have not spoken to him, I do not think he will be very hard on you."

At last the offer was declined. It was too early to go. His family was not settled. He must wait for news from Le Cap. "If you were in my position, my brother, and saw your gourdes running away in expenses and none coming in, faith, I believe you would be like me restless dreamy, and sometimes beside yourself. I hope therefore you will consider all this, even if my letters are so changeable."

Jean was now advised to take a cargo of beef, pork, \&c., to Le Cap. Some debts which Girard hoped to collect for him, "added to the amount of the coffee (168 pounds Pennsylvania currency) which I sold for you, and the funds you have in hand will make a tidy little capital, and while I do not wish to dictate I will say that if I were in your place $I$ would invest as much money as possible in such New England commodities as are most suitable for Le Cap, and go to Cap Français and make some money or at least recover as much as possible."

This advice was taken and Jean wrote that he would sail for Le Cap with beef and pork, and on the way would stop at Philadelphia. But "I should be very glad to know whether or not I may have consignments of your business. Please let me know in advance as I am resolved, in spite of offers made me by several merchants of this place, not to resume the commission business again unless I can shut the mouths of my enemies on the subject of your business." He sincerely hoped Captain Cochran would make a good voyage, but his brother would do well to beware of coming events. "My unexpected and I may say inconceivable misfortunes must convince you that nothing is impossible."

Girard replied: "I thank you for the prudent advice 162 
you give me, but my love of work, the only pleasure I have on this globe, will not permit me to entertain these prudent considerations."

Just at this time Girard bought a wreck and made a new offer to his brother, an offer which would relieve him of the unpleasantness of returning to Le Cap. "I have just bought a Bordeaux vessel abandoned here by her captain. The body of the vessel is in very bad condition, but the rigging, sails, cables are almost new. I am going to have her recalked and careened and send her to Marseilles with a cargo of tobacco.

"If you are not going to Le Cap and if you think a voyage to France would be more profitable you may take advantage of this opportunity to load on board for your account fifty or sixty hogsheads of tobacco, paying a moderate freight. I made large profits on this article recently, and have no doubt it is still a good article for remittance.

"I also need a passport bearer to France and you could fill that post and make something besides. As the vessel will not leave here for a month or six weeks you have time to wind up your affairs. But you must give me a definite answer at once, so that I may count on you or look for a man elsewhere.

"Messrs. Aubert, Chauveau and Bacon tell me that 8500 troops have arrived at $\mathrm{Le}$ Cap, and ask me for five dozen chairs and arm chairs for their sugar refineries which they hope to rebuild before long. This ought to show you that there is still some hope for San Domingo, and that all is not lost. For my part, I believe, if all these rascally aristocrats were in Guinea peace would have been restored long ago."

This offer was accepted and in November Jean Girard came to Philadelphia. The Bordeaux vessel mentioned 
in one of the letters as just purchased and intended for the Marseilles trade is more fully described in a letter to Samatan. Before buying the half interest in the Sally and while looking about for a brig suitable for the West Indian trade, Girard heard by chance "that a Bordeaux vessel of the capacity of about 500 hogsheads of tobacco, which put into our harbor because of considerable damage caused by a gale she encountered in our waters, and in which she lost all her masts, sails, rigging, will probably be condemned on the pretext that repairs would amount to more than the value of the vessel. As she was very solidly built in Bordeaux, in 1786 , I may possibly buy her, if sold cheap, load her with tobacco and consign her to you." The purchase was made, the wreck rebuilt and the vessel named the Good Friends to commemorate, it is quite likely, the renewal of friendship between the brothers. She became, in time, Girard's favorite vessel.

In July, August and September, I792, the Kitty, Polly, and Sally carried to Le Cap some twelve hundred barrels of flour. The reports which now came back concerning the conditions in the island were far from pleasing. Prices were low, sales were hard to make, the government was a buyer and paid in drafts on the Consul General at Philadelphia, and Aubert, Chauveau and Bacon complained bitterly of the poor quality of some of the flour.

Seven hundred and fifty-five barrels of flour had, by that time, been sold at from $53 / 4$ to 6 gourdes a barrel. "We still have left 445 barrels which we are holding at 6 gourdes, and just when we had expected that the government would need it, they came and ordered us to open our warehouses to find out how much we had. As we then had only about 150 barrels in the warehouse we at once declared these and one of us went at once to the 
authorities to make a bargain for the same since they had requisitioned it. We agreed on 8 gourdes per barrel payable in drafts on the Consul General at Philadelphia at six months from sight: but at the same time we stipulated that the government should take your 33 pipes of brandy at $21 / 2$ gourdes per velte or $11 / 4$ gourdes per gallon. This was accepted payable in the same drafts.

"We were very much surprised to hear that there were but 300 barrels of flour in the administration warehouses. All American commission merchants were forced to sell what they had at the same price and terms. We fortunately used stratagem and thus avoided giving more than 150 barrels and we hope to place the remaining 295 at a little more than 6 gourdes."

The sale of the brandy amounted to 37,552 livres, 8 sous, 8 deniers, and the cargo of the Sally to 58,501 livres, I 5 sous.

They were sorry that they were "compelled by force of circumstances to declare the entire return cargo, although II hogsheads and 5 quarter barrels on the said vessel (the Kitty) were freighted. The cause of this is to be found in recent measures adopted by our Colonial Assembly for an intermediary commission to raise a revenue in money for the colony. Not only was it decreed that a tax of a quarter be levied on all the revenue, to be paid by the planter, but the Assembly also appointed certain persons to take the weight of all commodities exported beginning to-morrow (November 27, 1792). Although we were not affected by these formalities, as fortunately we had hastened the loading of your vessel, we were nevertheless obliged to tell the truth in regard to what we had on board."

Bad weather and more trouble with the negroes detained the Polly till early in December. 
"Fresh trouble caused by the arrogance of the colored people, caused us a few days of uneasiness, but, as they have been suppressed, tranquility has fortunately been restored, although in order to accomplish this, the $\mathrm{Na}$ tional Civil Commissioner judged it necessary to have four persons exiled, the same who took part in the embarkation of those concerned in the unfortunate affair of the Igth of last October. This assertion of authority was not well received by everybody, but it was unquestionably well deserved, and the same thing will happen whenever too much partisanship is displayed by one side or the other. We have always thought it was best in a revolution like the present to be a mere spectator. This is the attitude we think we ought to adopt.

"Owing to an embargo on all shipping in the roadstead, your vessel was detained three days. We are very sorry for this as the season is already far advanced and we fear she will have to anchor at the mouth of your river," because of ice. 


\section{CHAPTER V}

LA VIRGINIE SOLD. GOOD FRIENDS EMBARGOED

ON this voyage of the Sally, Jean Girard went as supercargo. Instructions bade Captain Cochran, when he reached Le Cap, consult Aubert, Chauveau \& Bacon, and should the market be poor, and they approve, go on to New Orleans, sell the cargo for cash, and with lumber, dollars and indigo, if it could be bought at a moderate price, return to Cap Français. Should prices at New Orleans be high, he was to come with dollars and indigo to Philadelphia. Should it be thought best to stay at Le Cap he might do so, and during the winter make a trip to Georgia or South Carolina and go back to San Domingo before sailing for Philadelphia.

The instructions having been delivered, and the Captain having signed the copy in the letter book, he set off with Jean Girard in a pilot boat to board the Sally which had gone down the river lest she should be caught in the ice. What happened on the way was told in a letter from Jean. "An hour after. we left you the man who was steering the pilot boat stranded us high and dry in coming about, so that the tide being low and having our port side towards the open, we were laid so far over that we used the starboard for a deck. About half after two in the morning, finding ourselves afloat, we again made sail, and at three o'clock when in the open sea this same man stranded us high and dry again. It was no use to swear. After we had tried in vain to get her off, all four of us decided to get into the little skiff, with our baggage and board the first boat that should come down the river. You may imagine that with the wind, the cold, and the 


\section{THE LIFE AND TIMES OF STEPHEN GIRARD}

danger I had a hard time till at last we climed on board a shallop which took us to Marcus Hook. There we saw another shallop for Wilmington which had been wrecked the same night.

"From there we took the sloop which brought us here (Port Penn) on Friday evening and all on account of that rascal of a sailor. As the pilot and the Captain decided we could not go out in the snow and east wind, I proposed to Cochran to go with me about four miles into the country through the woods and the snow. We lost our way and did not get to our destination until evening worn with fatigue, which, added to the impossibility of finding our way in the woods, induced us to wait for daylight. What was my consolation the next day, Sunday, to find the wind in the north-west! We hurried to go on board; but the tide had not waited for us, that is what I call hard luck. That very Sunday evening the wind changed and has been contrary ever since, part of the time blowing from the south-east."

During three days they were wind bound, but in time Jean was able to announce: "We leave at last for Le Cap where I am most anxious to arrive in order to see for myself the situation of that unfortunate island. God have pity on it, and may $\mathrm{He}$ at least put me in a position to take up my work there once more. You know my position, my needs, my desire to regain public esteem and a certain reputation. You know that in order to accomplish this I have decided to make every kind of sacrifice. But I cannot hope to accomplish my desires, at least with satisfaction, unless you consign your business to me, not for the profit I will get out of it, since I do not ask for the smallest commission, but for the quantity of other business it will bring me. Of course you will do as you like; and without trying to combat 
your reasons, if you decide not to do so, I am quite resolved to bear patiently whatever misfortunes may still be in store for me."

A voyage of fourteen days brought the Sally to Le Cap.

"I must tell you that the colony is in as bad and deplorable a state as could be imagined. All the whites are disgusted and feel outraged by the vexations of the creatures who are now governing this wretched colony, and whom we tolerate in hope of at last coming into our own. But this will not be accomplished for many a day, for a third or more of the troops are sick and the rest not much better. The truth is all decent people say that the troops are composed of the dregs and offal of France, sent here in order to punish us. Do not think that what I say is prompted by party spirit. My dear brother, I open my heart to you that you may act accordingly and I cannot find a better comparison for the unfortunate people of San Domingo than the Incas of whom Marmontel speaks in his history; that is to say, the good people who inhabited Mexico before the Spaniards came to exterminate them. But, to come back to ourselves, matters have come to such a pass that I despair of ever recovering one quarter of what $I$ have on this unfortunate island."

Flour was selling so low, five gourdes a barrel, that Captain Cochran had decided to go to New Orleans. "As for myself, if I can finish trading all my negroes today, I shall go with him, for if I stay here I forsee that I shall die of grief or chagrin, from witnessing the impertinence of the class which I abhor and which, eighteen days ago, came near massacreing the whites at Le Cap and would have done so had it not been for the regiment of that name which we have since been forced to send 
away, a part to France and a part to Fort Dauphin, instead of rewarding them."

Aubert, Chauveau \& Bacon gave a very different account of affairs on the Island. Because of a request sent "by our National Civil Commissioner to M. de Ternant, our Minister to the United States of America, to induce him to have the drafts drawn by the Government on M. De la Foret accepted and paid," they had reason to "hope that the request will not go unheeded and that you will soon inform us that you have been paid in full for the drafts we sent you.

"Things are still peaceful in the city. Our brigands also seem quiet. Nothing has been seen of them, or practically nothing, on the plains for several days, as they have retired to the mountains. It is true that the soldiers have marched against their strongholds in the mountains, and as their number has been much lessened, one-half have died, and as the Spaniards are not furnishing them with ammunition and supplies as formerly, they are trying to collect at one place in order to defend themselves and resist the attack that will be made on them: but in spite of all their precautions they will have to surrender or be exterminated."

Captain Cochran by this time had decided not to go to New Orleans, believing that flour would rise at Le Cap. "Another thing which induced him to give up his intended voyage was the difficulty of loading wine for which the authorities are unwilling to give an export permit, and it would have been necessary to resort to means very difficult at the present moment because of the large number of inspectors recently appointed. More than that, it is absolutely necessary to keep the wine in the colony for the use of the troops who have become used to drinking it." 
The decision of Captain Cochran not to go to New Orleans brought a reproachful letter from Jean. He was now left in an island he detested. To see in command of the whites "officers belonging to the infamous caste of incendiaries and assassins, men who, because of their deeds, deserved the wheel," was too much. "I cry out for vengeance! Alas! why am I not far from here?

"I dwell in a country without laws for I cannot even enter my house although I have a perfect right to do so, and cannot collect a sou from my debtors. What am I to do? What am I to undertake?" Unless business conditions changed within the next few months he was ruined, and would bury himself in some obscure corner of America and wait for the hour which would end his sufferings, unless his brother would help him to work with the little he had left. He had given Cochran three slaves to sell or barter at Savannah for rice or indigo and was keeping three others essential to his comfort in case his brother sent him to Charleston or Savannah on business.

The Sally was dispatched to Savannah with coffee, sugar, and piastre gourdes amounting to 21,382 livres. At Le Cap business, Aubert reported, was dead.

"The general sortie having taken place twenty-five days ago all business has been suspended in order to have as strong a force as possible to march against the brigands. Our success has been so far quite flattering. We have driven them back into the hills where we hope to surround them. Some of the inhabitants of the yellow quarter have surrendered which make us hope we shall succeed. But time is passing and our flour is getting old. Some barrels from the cargo of the Polly are spoiled, and the mites have gotten into them, so that we have decided to let them go when an opportunity offers. We are selling it at any price from six to seven gourdes; but the 
difficulty is to deliver it to the bakers as we have no carts." $* * *$

"Business has been interrupted by the expedition against the brigands. Those who staid home do not pay and the bakers are nevertheless obliged to supply them daily with bread." Girard had written concerning this voyage of the Polly that he "noted with pleasure that your government has decided that one quarter of the revenues of your colony shall guarantee the payment of the drafts that the government has drawn on M. De la Foret. As I presume your government will send part of these commodities, or specie, to Philadelphia, I strongly urge you not to lose any time but solicit freight for my vessels. You may take it cheaper than anybody else so as to get the preference. M. De Ternant and M. De la Foret continue to assure me that all drafts drawn on the latter since the ninth of September last will neither be accepted nor paid till they receive orders from France."

To this Aubert, Chauveau \& Bacon replied: "We do not understand the refusal of M. De Ternant and M. De la Foret to pay the drafts of the administration. We know that our Civil Commissioners have done everything necessary to remove the difficulty in the way of their payment and we are convinced that you will be paid before long."

It was true that a tax of a quarter had been laid, "but the provinces of the South and West refuse to pay the tax, so that the whole charge is borne by the northern province. It is not much, however, as it represents less than $1 / 10$ of the revenue. Had the tax of a quarter been paid everywhere in the colony it would have produced a good deal of revenue for the treasury, everything would have been paid for in cash, and half the expense connected with drafts saved." 
The Sally reached Savannah about the middle of January; but the middle of March came before the captain was able to report that his cargo had at last been sold for £6r4 Georgia currency and that he was about to sail with lumber and a small amount of tobacco and rice.

As the Sally sailed down the Delaware River, in December 1792, Girard wrote, with pride, that she was the fifth vessel he had despatched within a month. One of the five was La Virginie. She had sailed in July 1792 and after a voyage of forty-one days made the port of Marseilles, to find the price of tobacco so low that the 150 hogsheads were stored. "It is impossible," Samatan reported, "to sell them now, at any price, owing to the great disorder in our city." "I cannot tell you anything about the cargo as I have not yet been able to land more than a few hogsheads because of another disturbance which has suspended all business. Do not be alarmed, however, concerning your goods. Our brave people wish ill only to the aristocracy, and not to the Propriétaire du Particulier."

The return cargo of La Virginie, sulphur, soap, almonds, oakum and what not, was valued at 68,425 livres. When despatching her Samatan said: "You no doubt already know that the declaration of war with the Emperor was made for the sole purpose of putting down the faction said to exist against the King, and that navigation will not be interfered with in the least, as the Emperor has refused letters of marque to privateers of those nations which asked for them. It is absolutely certain that no ship of any nation has been stopped, and I accordingly feel perfectly safe in despatching La Virginie." Late in October she was again at Philadelphia, and by the middle of November 1792 was on her way to Malaga with flour, coffee and pipe staves worth $£_{4917}, 6 s$. $6 d$., 
Pennsylvania currency. At Malaga the flour was to be sold if it would bring ten piastres courantes per barrel, If not, Captain Demay was to sail at once for Marseilles, where he was to go in any event for a return cargo. "The sad news," Girard wrote Samatan, "we receive from time to time from France makes me fear that Spain may commit depredations on the French flag and I have therefore instructed Captain Demay not to put in at Malaga until he is sure that France and Spain are at peace." "I shall instruct Messrs. Thellusson, Frères \& Co. to place about $£ 2000$ sterling on the hull and cargo of the brig La Virginie, as I have placed the rest of the insurance in our city."

While the brig was on her way, Girard informed Samatan of his purchase of the Bordeaux wreck and proposed that it sail under his name as owner. "The French ship of which I spoke to you needs a general overhauling and $I$ have had it placed in a dockyard to be put in the best possible condition. This will keep her here until next Spring when I shall send her to you with a fine cargo. Although our French Consul assures me that the vessel may sail under my name, I shall be charmed to have her appear to belong to you. I can easily put her in your name by declaring before our Consul that as I have funds belonging to you, I have bought the vessel for your account. If you will consent to do me this service, let me know at once what your intentions are so that I may attend to the formalities before the vessel sails."

If Samatan consented he was to engage "a good Captain, well acquainted with the Ponant (the Atlantic coast of France, Spain and Portugal)-not a Provençal nor a Bordelaise I beg-who would come here in $L a$ Virginie as mate and take Captain Demay's place on 
the return voyage." Captain Demay was to command the rebuilt brig. M. Samatan readily gave his consent. But ere La Virginie arrived he wrote letters which defeated the plan. "I have no objections to offer in regard to the vessel which you have bought and which you wish to have sail under the French flag; but I must tell you that there is a Commercial decree which forbids a Frenchman to buy a vessel not of French construction. Hence you must be sure to procure a certificate stating that the vessel was built in a French port, and add it to the ship's papers. Anyway it might be well at present to have her as well as La Virginie sail under the American flag, for we are on the eve of a rupture with England. You would better be guided by what you hear directly."

As the new year opened other correspondents sent like warnings.

In January, Messrs. Herries \& Co., of London, regretted to state that, "as the probability of war between this country and France is much increased, prudence requires that we should revoke the credit which we confirmed to you" for two thousand pounds sterling. Samatan, at Marseilles, was sure "we are on the eve of war with the English which is very bad for our commerce, and we regard it as utterly ruined. War is considered inevitable; energetic preparations are being made in England where they are working day and night and the naval force of that power will be greater than it has ever been." "I must inform you that the introduction of coffee from the English and American ports in America is prohibited. If La Virginie comes here directly, I shall have the coffee examined and if it is green shall send it to Genoa or Leghorn to be sold. If it be common I shall send it to the Levant, as the latter quality is not suitable for Italy." "We appear now to be on the eve of war 
with France although there is no absolute certainty of it," wrote Herries \& Co. in February. "The Minister declared in the House of Commons on Friday last, that altho' the moment was not yet arrived, involving us in it, 'he should belie his own belief were he to say he thought it could much longer be avoided.' We have since learnt of an embargo having been laid on English and Dutch vessels in the ports of France, and even at Ostend, in consequence of which orders are given here that no English ships be permitted to clear out for the ports of France or for any country occupied by the armies of France, and an embargo is to be laid on all French vessels whatsoever in the ports of Great Britain. Spain is also arming and there is now hardly any doubt that in case of war she will act in concert with us against France."

War was declared by France on the first of February I793 and a letter from Marseilles, written a few days later by Joseph, Bovay \& Co., successors to Conaz \& Co. to report the arrival of La Virginie, announced that "owing to the fact that war has broken out between our republic, on the one hand, and England, Holland, \&c., on the other, you will make a fine profit out of the cargo. Please accept our congratulations. An idea has occurred to us that we ought to have told you of before, although either you or the captain have probably thought of it. That is to change the vessel from the French to the American flag, if that is possible, either by making a mock sale of the vessel, or in any other way you may deem most suitable."

She was not destined to leave Marseilles. Samatan wrote, in March, "as it is hopeless to think of despatching your ship La Virginie, since there is an embargo and no convoy has been arranged for, I have decided to disarm and put her in the care of a good watchman whom I 
have selected, to sleep on board, and later take charge of her this winter. As Captain Demay did not wish to remain idle, unless I could continue his salary, I dismissed him, his transportation to St. Valery having been settled at 450 livres. I paid him that sum for which please give me credit.

"This plan of leaving the vessel unemployed even in the Mediterranean is one I have adopted for my own vessels, and all others confided to my care, because it is evident that we shall not be superior, or even equal in strength to the other powers on any sea, and our commerce will be totally unprotected." Some of the return cargo, forty tons, was shipped on the American brigantine Bacchus. The invoice and insurance amounted to 39,906 livres, I 5 sous, and the freight to 1560 piastres fortes. About the middle of August the Bacchus reached Philadelphia.

Captain Demay reported, late in April, "I have paid off my crew and am about to leave for St. Valery. If I can, I will come to Philadelphia. I must tell you that I leave La Virginie in very good condition and with a good shipmaster who is paid 30 livres a month. The vessel is completely stripped down to her lower seams and all the yards are in the hold, with an inventory of all there is on board as well as on shore, and the pilot's instruments. Commerce is at an end in France, at present, and Americans will have a free hand. At present the Americans and Danes are the only people who can come here."

Early in March the news of coming war had reached San Domingo and Aubert, Chauveau \& Bacon wrote:

"The news received two days ago, from a vessel coming from Bordeaux which put in at La Rochelle, after a voyage of 42 days, is not calculated to allay our anxiety in regard to the continuance of peace. A war with Eng-

Vol. I-12 
land is still feared, and our colonial commodities have experienced an additional rise of some importance in all our ports. At Marseilles the entire cargo of coffee of a vessel which was expected there was sold at 45 s." The price could not possibly have been better, but on the other hand was depreciating greatly.

"The same vessel brought us the sad news of the final conviction of the King of France and of his cruel end on the scaffold on the 2Ist of January last. It is to be presumed that the Queen and the Dauphin will suffer the same fate. What will be done by the foreign powers as a result of these events? We shall not disguise from you, dear sir and friend, that we anticipate even greater evils in the future. Already it is rumoured that several members of the National Convention who were most instrumental in condemning the King have been assassinated, and that the attorneys who were appointed to defend his cause have been denounced. France must be in a very critical condition and the prospect of peace must be more remote than we thought. We are waiting with great impatience for additional news. What interests us particularly is to know whether we are at war or at peace, for this uncertainty is a great hindrance to business, and the embargo which has been placed on all vessels bound for Europe is most injurious to commerce."

Their fears of coming war were soon "realized by the arrival of an advice boat which came here the day before yesterday (March 18 th) after a voyage of 26 days and brought us the news. As yet we know the text of the declaration of war through the chief of the station, as the Civil Commissioner is at St. Marc where the official letters were at once sent to him. All that we know, and it is enough, is that war was declared on the 3 Ist of January last between the French Republic on the one side, 


\section{GOOD FRIENDS EMBARGOED}

and England, Sardinia, Holland, and Russia on the other side, without counting Prussia and Austria, which we already knew were at war. It is not known whether Spain has also declared herself against France or whether she will maintain a neutral attitude.

"We hear that they are going to send us a new General and perhaps also new Civil Commissioners who are to arrive before long, but without any troops. We therefore run the risk of being at the mercy of any foreign force that may be sent here, but we presume that the Americans will still have access to our colonies."

"The declaration of war was published here yesterday (March 23d) in due form, so there are six powers in arms against the French nation, and we expect to have Spain as well. Judging by the preparations she is making both on land and sea, she cannot maintain neutrality very long.

"As a result of the declaration of war several English and Dutch vessels which were in this harbor have been seized, and we also have several Spaniards who are afraid the same thing will happen to them at any moment. The owners are hastening to despatch them." Flour had risen to 9 gourdes per barrel and rice to 30 livres per quintal.

Now that all direct communication between France and her West Indies was cut, half a score of letters came to Girard with enclosures he was to forward to France, or with requests not to fill orders sent to him from San Domingo.

"If," said one, "American commerce is to be exposed to the risks of war, and if on the reception of this letter, you have not bought the goods that we ordered of you, do not buy them. If they are already bought, ship them to us, and distribute the risk over 5 or 6 vessels, without 


\section{THE LIFE AND TIMES OF STEPHEN GIRARD}

insuring, so that if some of the goods have the luck to get through they will indemnify us for any that may be taken. ***

"We believe that the United States will preserve their neutrality; but as they do not possess an armed force that might compel respect, they, or rather their vessels, might be subject to search, and in such an event any merchandise recognized as French would certainly be confiscated and regarded as a fair prize. To avoid such an annoyance we ask you to load the goods as American property."

The letters of Jean Girard written from Le Cap during these days are full of dimal forebodings. On the eighth of February he was "leaving tomorrow for the army which is encamped near where I have my plantation." The object, he said, of the letter is "to tell you, my dear brother, that my only hope is in you. I may tell you that by remaining a few years in San Domingo I hope to collect my roo to I50,000 livres, but how can I make up my mind to do so unless I get some encouragement from you? You are the only one who can give me this encouragement and thus enable me to collect my money." Not only was he reduced to living like a pauper, without any business whatever, when he formerly had so much, but now that his brother's vessels were seen to go to Aubert, both enemies and acquaintances looked at him askance. The former had so impressed the Captains with his worthlessness, telling them that he was unworthy of anybody's confidence since his brother, who had welcomed him in San Domingo, did not send him any business, that the Captain "I placed in command of Patterson's brig, and who formerly sailed under my orders" did not dare come to see him. The letter closed with charges that Aubert, Chauveau and 
Bacon were cheating his brother in their purchases of return cargoes.

Three days after his arrival at the Camp at Grande Rivière, "it was decided, because of the number of sick, malcontents and deserters, to retire without having subdued the brigands," and he had the ill luck to be within reach of his plantation without meeting a single one of his negroes. He was ready to undertake anything in the world in order to be at work and make some money. $\mathrm{He}$ would attend to his brother's business at Le Cap, or be supercargo, or passport bearer in any of his expeditions.

Girard replied he was not responsible for the change in the destination of the Sally, and the detention of Jean at Le Cap. He ought to know "that after delivering my instructions to Captain Cochran and giving my word to M. Dominique Langoran I would do all in my power to have the Sally go to New Orleans. I am incapable of giving orders that would disappoint you and that excellent man, M. Langoran. One cannot help agreeing with Dr. Pangloss. These little lessons teach us to know mankind. I am sorry to hear that you are not as patient as you ought to be. You ought to remember that there never has been a revolution without unpleasant results. Let the mulattoes, the gossips, and politics alone and attend to the task of gathering up the remains of your fortune in order, if possible, to repair the losses you have suffered.

"I am sorry that trifles grieve and annoy you so much." As he had explained, common courtesy and his own interests forbade him taking his business from Aubert, Chauveau \& Bacon, and he could not think of consigning his shipments to Jean. Since Jean could see no possibility of making collections for himself it was not likely he could make them for others. "Besides, I assure 


\section{THE LIFE AND TIMES OF STEPHEN GIRARD}

you, that I have been so long chained down to work and have suffered so much crushing grief in silence that my health has become greatly enfeebled and I am almost disgusted with business, so that it is quite probable that I may before long decide to wind up my affairs." If Jean made up his mind to stay at Le Cap and went into business with M. Hourquebie "for American business only" he would contribute all he could to the success of the firm. "But you must understand that in the present state of affairs in San Domingo, and even at any other time, it would be very imprudent to consign business of any magnitude to a firm represented by a single man."

How seriously Girard at this time thought of retiring from business is evident from letters written to others. Thus, in August I792 he wrote Samatan: "Another motive which induces me to take advantage of the state of the market is, that it will enable me in three or four years to retire to my native land, possibly to your city." Whereupon Samatan wrote back: "I must say a word about your return to France. Would you consent to my sending you a young man who would familiarize himself with your business during the time you still have to spend in Philadelphia, so as to become your successor after you have left? If this plan suits you I will find a young man whom I will supply with funds enough to continue the business."

The depression of spirits which produced the disgust with business soon passed away, and long before he heard from Samatan all thoughts of returning to France had vanished. His troubles and annoyances were small in comparison with those of his brother who had lost business, money, property and slaves.

"I was going to send you my drafts on the French Treasury but now war has been announced I consider 
them worthless. I shall try to dispose of them here for what they will bring. My ill luck still pursues me." All he had in the world would not amount to more than 5,000 gourdes, and to avoid drawing on this capital he begged his brother to invest it for him in some good security that would pay $6 \%$ a year. Unless he could find some lucrative employment he would "either decamp or perish." However, be his lot what it might, he must be patient. "We are going to be the most unhappy people in the world unless some foreign power comes and takes possession of us, for, since our negroes are in revolt and we are dying of hunger because of the evident blockade of our coast it is a fact that our situation will be extremely critical."

"It was learned to-day that war had been declared with Spain. If this be true, I consider my fifty negroes I have in the mountains as lost. After such a reverse of fortune is it possible that I can look favorably on the French Revolution? Oh, my brother, may God preserve you from such a blow."

The next day, however, he was full of hope. "The declaration of war has made a great sensation and it is believed that neutral vessels, if there are any, will do a great business in freight, that is to say, if their captains are trustworthy men and can be passed off as the owners of their vessels instead of the actual owners. Freight will rise four or five sous per pound. If you intend to try such a voyage to Bordeaux, after remodeling your ship, or to speak more correctly, with your new ship, under the American flag, provided the Americans remain neutral, as you will soon find out, and as I believe will be the case at least long enough to make this voyage, I have decided to take a share in such a voyage to the extent of 5000 gourdes both on the outgoing cargo to 
Bordeaux and on the return. If I can be the supercargo and captain or mate, with a supercargo's commission," then he would be glad to go.

The Sally reached Le Cap late in April after a voyage of eighteen days and it was finally arranged that Jean Girard should return on her, or on the Polly, which had just arrived at Le Cap. She sailed from Philadelphia in April and had no sooner entered port than, wrote Aubert Chauveau \& Bacon:

"The Controller of the Administration lost no time in representing to us the need of the Administration for flour. We answered him that we had very little of it. We declared only 300 barrels when the vessel entered, and that it was already in part sold. We shall accordingly lose no time in selling it at 9 gourdes if possible. In order to anticipate any difficulties that may be put in our way in this matter we again offered brandy payable in drafts on the French treasury, but as we should like to get 5 gourdes per velte and the administration was not willing to give more than four, we decided to give them time to reflect."

Five gourdes were asked because it was not possible to know what would be the loss on paper money. "We fear, however, they will demand as a condition, that we furnish a certain quantity of flour, and if we are forced to do so, it will be well, in order not to lose the sale of the brandy, to furnish about 250 barrels of flour still unsold, from the former voyage of the Polly, as this flour is in the worst possible condition, because of the mites in it, and its great dryness, so that it cannot be rated as other than common flour." Twenty barrels of brandy at $5^{8}$ livres per velte and 150 barrels of the old flour at 135 livres per barrel, were finally sold to the Administration. When about to sail for home the Polly was detained by 
"an unexpected sortie against our negro brigands undertaken by our general as it meant the closing up of all the stores in the city, and a proclamation forbidding coopers, and casters to work." Her return cargo was worth I44,885 livres, and on her came many passengers. A few days later the Sally followed her with a cargo valued at 45,087 livres. The cargo she brought to Le Cap from Philadelphia had been sold for 65,720 livres.

While still ignorant of the condition of affairs abroad, Girard was busy securing a cargo of wheat in Virginia for La Félicité, a vessel chartered by Samatan to go to Petersburg, and ordered the purchase of wheat and tobacco for his own account. They were to be shipped to Marseilles on La Virginie and the brig undergoing repairs. But in February came the letters from London telling of the prospect of war. Whereupon Messrs. William and James Douglas, of Petersburg, were notified that, "by my last advices from London dated the 2nd ultimo, it appears a Great Probability of war between France and England in consequence of which my friends in that place have given $8 \%$ premium on part of the brig La Virginie, from this place to Marseilles. This circumstance does not induce me to go on in my shipments to France, therefore wish you will postpone your purchases on my account until further advice."

The Petersburg firm having meantime chartered a second vessel, the Joseph, were requested "to load that vessel with wheat as soon as possible. As we have still a probability of French war, please to fill up the Bill of Lading and Invoice in such manner that the property will not appear to be on account of M. Samatan." "Respecting the report of war between France and England, the probability of it increases here every day, in fact I have received from Cap Français letters dated the 12th, 13th, 
and I4th ultimo, the which mention that on the rath same month (February) a paquet arrived there in 29 days from france who gave them reason to be feared of a war as Immediately after the arrival of said Vessel in that port Government has put Embargo on all European vessels."

What to do with the snow they had chartered he was in doubt; but, as his orders were positive he decided, that "the said snow with her cargo of wheat shall proceed Immediately for Marseilles, but in case the Captain of the Said Vessel shall hear in his passage of a war between france and England being Declared, he shall go with his vessel and cargo in the port of Barcelona and there wait for orders from M. Samatan." The invoice and bill of lading were to state that the wheat was shipped by "Stephen Girard, Merchant, Philadelphia, consigned to M. Samatan of Marseilles," so that, "in case of war I may claim that cargo as American property."

More bad news followed and two weeks later Messrs. Douglas are informed (March 18 th) that "by two vessels arrived in this port in a short passage from Portugal we hear that the King of france was beheaded at Paris on the 2 Ist of last January. Should this news be true it will occasion a general war in Europe," and are again requested to fill out the bills of lading as instructed. During the first week of April letters from Le Cap and from London having confirmed the report that France had declared war against England and Holland, Messrs. Douglas are instructed to procure an American vessel to take the cargo of wheat in the British snow Joseph and go at once to Marseilles, "provided it can be done without paying any damages for cancelling the charter party of the said snow Joseph, otherwise the said snow must proceed immediately to Barcelona." Should it be impossible to 186 
find such an American vessel they might sell the wheat at first cost, commissions and charges. If neither of these things could be accomplished the wheat was to be shipped on an American vessel to Bordeaux.

The charterees at first refused to permit the Joseph to leave port. The war, they held, if it really existed, canceled the charter party. After much discussion an agreement was reached that the Joseph should sail for Barcelona, and the question of freight be submitted to four arbitrators, who decided "that seventeen pence British sterling per bushel" was "a just and reasonable freight." The cargo consisted of 8267 bushels.

This agreement was made on the Igth of April, but the presence of a French cruiser off the coast, and contrary winds, delayed the Joseph till late in May. Scarcely was she out of sight of land, however, when she was captured by the French privateer Le Sans-Culotte. Captain Prance of the Joseph made a brave fight, nor was his vessel taken till he had been wounded in the thigh and lost both his hands. The captor then went with her prize to Baltimore, where she arrived on a Sunday evening late in May.

On the log of Le Sans-Culotte, Captain Ferry, according to Baltimore newspaper, was this entry: "May 22nd, at 5 P.M. saw 4 sail of vessels and gave chase: they hoisted English colors, fired each a gun to windward and formed a line. The Sans-Culotte crowded on sail and at II o'clock came up with them and engaged them for five glasses. The snow Joseph, from Norfolk bound to Cadiz, being to windward, brought all her guns to bear on the Sans-Culotte in order to discharge them into her, then to up her helm and run her down: but the Sans-Culotte's fire proving too warm, before the design could be executed, the Joseph struck, the cap- 
tain having received a cannon ball through the right thigh and both his hands cut off. A squall arising the three other vessels bore way. The Sans-Culotte then hove about to take care of her prize and finding the captain of her so dangerously wounded and having three wounded on board the Sans-Culotte, Captain Ferry, gave over the chase."*

Washington was at Mount Vernon, when, in April, the British packet arrived with letters and newspapers announcing that war existed between France and Great Britain. With all possible speed he hastened to Philadelphia, summoned his Secretaries, and put to them sixteen questions. Should Congress be assembled? Should neutrality be declared? Were the treaties made with France when a monarchy binding on the United States now France had become a Republic? Did the treaty of Alliance apply to an offensive war? Was France engaged in an offensive war? Should a minister from the French Republic be received? were some of the questions asked. The answers were that the treaties were binding; that the war was offensive on the part of France; that the treaty of Alliance did not apply to an offensive but to a defensive war; and that the French Minister should be received.

April 22nd, accordingly, Washington issued a proclamation of neutrality, and that day the French frigate L'Ambuscade with the French Minister, Citizen Genet, on board arrived at Charleston, South Carolina. Scarcely had he landed when he began his evil work. He had not yet presented his credentials. He had not yet been formally recognized as Minister by the President, nor received a transfer of the books and papers of Ternant, the minister he came to succeed. Nevertheless Genet

*American Daily Advertiser, June I, 1793. 
now commanded each French Consul in the United States to act as admiralty judge for the trial and condemnation of prizes brought in by French cruisers and privateers. That there might be prizes he offered letters of marque to American citizens, and in a little while three swift sailing vessels were bought, armed, equipped as privateers, named Le Citoyen Genet, Le Sans-Culotte, Le Vainqueur de La Bastille, and, in defiance of the proclamation of neutrality, sent out from Charleston, to wage war on homebound British merchantmen. It was one of these, Le Sans-Culotte, that captured the Joseph.

Girard at once appealed to Citizen Genet: "Your petitioner Etienne Girard, French merchant, established for several years in this city, where he has had constant business relations with the principal commercial cities of France, and particularly with Citizen Samatan of Marseilles, states that he filled some orders from the said Samatan and had shipped 8200 bushels of wheat," that it was sent to Barcelona in ignorance of the fact that Spain was at war with the Republic; that the wheat was "for the account of a Frenchman, made by the order of the exporter who is French, and an agent for Samatan, sole owner of the said cargo of wheat," and requested Citizen Genet to "kindly order that the cargo of wheat on board the snow Joseph, Captain Thomas Prance, taken by the privateer Le Sans-Culotte, to be returned to the petitioner."

The petition was made in vain and late in June the Joseph and cargo were condemned and the wheat sold at auction by order of the French Consul.

Meantime Samatan was informed of the loss of the wheat in a letter which; Girard wrote, "will be delivered to you by my new ship Good Friends, Captain Francis $\mathrm{H}$. Ellison, whom I am sending to Bordeaux, consigned to 
my brother of Le Cap who is a passenger on board the ship, and Messrs. Bonnafé frères et fils of that city."

Besides her cargo worth " $£ 6993,14 s$ and $6 d$. of our money, which corresponds to $18649 \frac{90}{100}$ piastres fortes," she carried nine drafts drawn by the San Domingo Government on the French Treasury for 48,669 livres tournois, given in payment for 150 barrels of flour and 20 pipes of brandy taken by the government.

These were to be sold as soon as possible. On his arrival at Bordeaux, Jean Girard was to consign the cargo to Bonnaffé frères et fils, or if any unforeseen accident had ruined "these honest merchants," address himself to any other house of good reputation. Should it seem wise to despatch the Good Friends to the islands he might do so. If, on arrival at the islands, good freight could be obtained for Europe he might take it. If it seemed imprudent to go to the islands, he was to return with red wine, oil, soap and brandy. On all sales he was to have a commission of three per cent., the same on all purchases, and five per cent. on freight. While at Bordeaux he was to do all in his power to settle the family affairs "so that each may have his rights," and "settle whatever old accounts I may owe in that city." If captured and taken to London, "which can only happen in case of war between England and the United States of America," he was to apply to Messrs. Thellusson Bros. \& Co. for such assistance as he might need. "If you settle our family affairs and our sister Victoire gets her share, I think it will be best not to let her have control of the money, but give her share to some responsible man who will pay her the interest quarterly. As for Dame Lafargue, it is unfortunate that some relatives nearer than I do not assist her. It seems to be my lot to do so and I will not revenge myself on her, but will do for 


\section{GOOD FRIENDS EMBARGOED}

her what she would never have done for me. If you think proper you may pay her for my account five hundred livres tournois."

June second the Good Friends set sail and from Delaware Bay. "Your ship," wrote Jean Girard, "sails superbly but she makes everybody tremble, even the crew, she lies down on her side so horribly and makes me fear she will not carry all her canvas." A calm forced the Captain to come to anchor some thirty miles from the Light House "where we were struck by a squall from the southeast which obliged us to lower our topsails and topmast, and still the vessel heeled tremendously. We were lucky to have our boats inside, otherwise there would have been desertions. If any of the passengers understood English I really believe the vessel would have returned. I took good care not to interpret what happened, though it gave me a great deal of uneasiness, as it did to have the Captain down with the fever."

"It is with regret," the Captain wrote, "that I inform you the ship is very crank, so much so that I have had some disturbance with the people to get them to go to sea in the ship. We have been obliged to get the top gallant mast and yards down, but will get them up every opportunity we have at sea. On her return to Philadelphia she will require to have all her spars shortened to make a safe ship of her as, at present, I think her very unsafe."

All these things, Girard wrote his brother, would give him great anxiety were he not "perfectly acquainted with the causes that make her weak under sail. These are:

I. "The character of her cargo and the improper stowing of it in her hold.

2. "A new ship is always light at the bottom because 191 
the wood is very dry, and as the masts are green the weight of them changes the usual condition of the ship.

3. "The strongest reason why a ship does not carry her canvas properly is, that she is out of sheer. This is the trouble with the ship Good Friends, which draws two feet more forward than aft. That is to say, as she draws fourteen feet aft she ought not to draw more than twelve feet nine inches forward instead of fourteen feet six inches. This great difference makes her lose her balance altogether."

The labor of despatching the Good Friends delayed the loading of the Polly, but on the evening of June I 2 th, in command of Captain John Congdon, she sailed for Le Cap with 722 barrels and 62 half barrels of flour, casks of almonds and baskets of oil, and July third entered the harbor to find the town of Cap Français in ashes and hundreds of her citizens murdered.

The three commissioners for San Domingo were Sonthonax, Polverel and Ailhaud. Accompanied by transports carrying 6,000 troops, they reached Le Cap on September 13, 1792, dissolved the Assembly and sent Governor Blanchelande to France, where he was soon guillotined. General Desparbés became governor in his stead.

With all the acts of the Commissioners we need not be concerned. It is enough to know that they soon forced the new governor to seek safety in flight; that two of them, Sonthonax and Polverel, then compelled their associate Ailhaud to quietly leave the colony, and by the opening of the year 1793, were masters of San Domingo. The war declared against Great Britain in February, 1793, forced the rulers of France to pay some attention to the safety of the colony and a new governor, M. Galbaud, an officer of artillery, was sent to put the 192 
colony in a state of defence. But the two commissioners now hastened to Cap Français with a force of mulatto soldiers, declared his credentials invalid, and ordered him to embark on a sloop of war returning to France. The mulatto troops then proceeded to treat the whites of Le Cap as they had those of Port-au-Prince, and went so far as to insult and abuse the sailors on shore leave. The seamen, some 3,000 in number, cried out for vengeance and on June 2oth, 2,000, headed by Galbaud, landed and set out for the government house where dwelt the Commissioners defended by their troops. All day long the fight raged in the streets. Sure to be beaten on the morrow the Commissioners, that night, sent a call for aid to the revolted negroes on the Plain. One negro leader, Macaya, responded and about noon on the 2 Ist of June, entered Cap Français with several thousand slaves and began an indiscriminate massacre of men, women and children. Many of the whites rushed to the water front in hope of finding shelter on the ships in the harbor. But the mulattoes cut them off and the slaughter continued till evening. Fire, meantime, was set to the buildings and more than half the city was consumed. On the morrow thousands of negroes poured into the town and slaughtering and plundering went on for two days. Galbaud, unable to offer any relief, sailed for the Chesapeake followed by a great fleet of ships loaded with refugees, who counted themselves fortunate to escape with life.

News of the burning and massacre reached Philadelphia by two vessels which arrived from Le Cap on the 6 th day of July. Girard at once wrote his old friends, Aubert, Chauveau and Bacon, "I hastened to inquire about you and was assured that Messrs. Chauveau and Bacon had escaped to the roadstead; but it was not

Vol. I-13 
known what had become of M. Aubert. I sincerely hope our estimable friend escaped the fury of your infamous brigands.

"After such a disaster I suppose you have left the unfortunate island where you used to live, but if for any reason you have remained, I will ask you, as a true friend, to wind up both your own affairs and mine and take advantage of my brig Polly, if she be still in the harbor, to come here and enjoy the peace which our Republican Government, founded as it is on the rights of man, assures to all its inhabitants."

To Messrs. Hourquebie frères, he wrote, "I at once hastened to inquire about you, but no one could give me any information. I was merely told that your quarter had been reduced to ashes. I hope that your person and your property at Le Cap escaped the fury of the authors of this catastrophe."

To his brother, at Bordeaux, he wrote, "You have no doubt heard of the accident at Le Cap. The city was reduced to ashes and most (if not all) of the whites massacred by the mulatto and negro brigands from the plains, who entered the city, and looted all the houses without distinction. Such is the news received from various passengers who escaped the massacre and came here in the greatest distress, men, women, and children, on three vessels from that unfortunate harbor. I did not get a letter by these opportunities and only some doubtful information about our friends. I am told that poor $\mathrm{M}$. Aubert has been killed; and that M. Bacon and M. Chauveau escaped to the roadstead, the latter after being wounded. It is also stated that the convoy in the harbor, destined for France, sailed for the continent. We look forward here to the arrival of a large number of refugees in distress." 
The first news to come from his friends was a letter from Chauveau written at Baltimore on July 15 th:

"You have no doubt already heard, by vessels which must have arrived before us, of the unfortunate event that has befallen our unhappy city of Le Cap, and the reasons that forced us to take flight with many other inhabitants and embark on the vessels of the convoy which put us ashore, M. Bacon and myself, at Norfolk, Virginia. Thence a pilot boat brought us here. Worn out by the misery we had gone through at Le Cap, as well as by the cruel sea trip, we shall stay here a few days before going to see you.

"It is with pain in our hearts that we inform you we have saved nothing at all from our business, neither money nor papers, and what adds to our grief and affects us most deeply, is that we were unable to reach the house of our respected chief, M. Aubert, which is at some distance from our own, and do not know what had become of him and his family. We had left our money in his house for reasons that we shall tell you at our first interview, when we shall also tell you about our affairs.

"As we are somewhat indisposed because of the fever, we shall have time to get your answer before leaving for Philadelphia."

Girard replied that he was "genuinely moved by the report of the misfortunes you have suffered and the losses you have sustained at the hands of the enemies to peace and tranquility." It was, he said, most unfortunate for Captain Congdon that none of the firm to which he was consigned remained at Le Cap. All this made him most anxious for the fate of his venture.

His anxiety was soon relieved by a letter from Aubert, written at Le Cap on July 6th.

"A frightful event happened in this city on the 2oth 195 
of last month." The inhabitants, colored people, free negroes and slaves, armed themselves, sacked every house in the city and burned all but three hundred. "You will hear the details from many persons who have embarked for France on the convoy. Many American vessels which left here on the 24th will bring you a number of unfortunate refugees. I was in the house occupied by my wife and family but left it hastily to seek refuge on the Morne du Cap (on the bluffs) where we witnessed the terrible event. The house was both looted and reduced to ashes. When quiet seemed to be restored in the city, I heard that my place of business was not burned, and full of hope, and a desire to know its state of affairs, I went there a week ago and found it stripped of all its contents. Eighty-five hogsheads of rice from the cargo of the brig Sally, Captain Cochran, had been emptied, and soap and trade coffee had been carried away. Papers in the counting room were in the greatest disorder. Everything was upset, and the contents of the room scattered about the street. It will take a long time to clear up the confusion and collect the scattered papers, some of which will surely be missing. I shall attend to this duty at once in the interest of all who have suffered losses if I am not disturbed, for I am alone, my partners having sought safety in flight like many others. I do not know where they have gone."

"Our bakeries being destroyed, and the workmen scattered in flight, I was obliged to offer 600 barrels to the Administration who refused to give ro gourdes, which I asked, and gave but 9 gourdes, so I made the sale at that price and am about to deliver the flour. It will have to be paid for in colonial commodities and the crew will have to transport it to shore on a lighter I have been authorized to take." 
Every day brought more letters from refugees at Baltimore. M. Lousier, "an unfortunate victim who escaped the rage of the brigands at San Domingo and arrived in this port on the ship La Bonne Henriette of Bordeaux, Captain Dubourg, being one of a fleet of r ro vessels, begs you to enable him to draw 24 gourdes in order to buy the cheapest kind of clothing that I can cover myself with, for I escaped with an ordinary duck coat and trousers that I happened to have on at the time. I abandoned 30 negroes and my place in order to save my life. Would to God I had the courage to take my life and escape from the horror of such a cruel recollection. As soon as I arrive at Bordeaux I will not fail to repay whomsoever you may entrust with your orders." Hourquebie frères on board the ship La Bonne. Henriette, anchored off Baltimore, wrote that as they expected to make a brief stay in Philadelphia, and would be accompanied by the Captain of the ship, Girard would do them a real service if he would "look out for a little lodging for three people so that we may move in as soon as we arrive."

M. Goutier "was forced to take refuge on board a vessel after the burning of Cap Français and arrived here (Baltimore) on the IIth of this month. After the misfortunes that have happened to me I have decided to leave for France by the first vessel that sets sail and I will therefore ask you, dear Sir, if you have not disposed of the proceeds of the 6000 of Coffee which I sent you by your vessel the Polly, to keep it till I arrive in your city."

Messrs. Dubourg frères \& Carrere wrote from Baltimore, "You have no doubt heard of the disaster that has happened at Le Cap, and of the total loss of the city. You will have heard that we have been forced to take ship without a moment's reflection and with nothing but the clothes we had on our backs. It is true that at 
first we thought it was nothing more than a private quarrel and were far from supposing that it would involve the entire loss of our city and perhaps of the colony as well. But after three days of burning and killing the merchantmen at anchor in the roadstead at Le Cap, fearing for their safety, demanded and obtained permission to put to sea, under government convoy, and we went on board almost naked and had no opportunity to go back to our places of refuge. From this disaster we escaped with our lives and the lives of five of our sisters and cousins, who were put on board the same vessel. We had to abandon our oldest brother, the mother-inlaw of our M. Dubourg, Sr., and three children of our sister Madame De Bonnecaze, Jr., who had wandered about in the hills near the city." They had lost 860 thousand livres in bills, from 80 to 90 thousand livres in merchandise stored, 150 thousand livres in furniture and clothing and three large plantations, and had nothing left save the proceeds of a consignment of coffee sent in October, I792.

To all these Girard replied promptly and kindly. Hourquebie frères were assured, "I am truly sorry for the misfortunes you have suffered at Le Cap. I am one of those in our city to whom the sacking of the city will be the most disastrous, but we must be philosophical and try to recoup ourselves elsewhere.

"I sold your coffee at $13-3 / 4 d$. per pound, payable at four months, and enclose a copy of the letter I wrote you about the matter." He had on the stocks a new bark, the Kitty, which had been lengthened ten feet, and might send her to Le Cap if one of the Hourquebie brothers should make up his mind to go thither, "or down to Plymouth* on the lower coast." The daily arrival of

*Capital of Montserrat. 
strangers in the city had made boarding accommodations very scarce; nevertheless, he had secured two rooms and board at 6 gourdes per week each. M. Lousier was told that M. Paul Bentalou of Baltimore would advance up to 50 gourdes, and Mr. Bentalou was requested to "do everything you can for these unfortunate people." Dubourg frères \& Carrere were informed that their coffee had been sold for 3900 piastre gourdes and 2600 piastres remitted to Messrs. Lynch \& Stoughton of New York.

As July wore away, more and more letters and appeals from refugees came to Girard. M. Langloire, senior attorney for the Council, Cap Français, sent a bill of exchange on Baltimore for 320 gourdes and said, "M. Aubert will send you a number of articles in gold and silver as per the enclosed memorandum, being what is left of a fortune which, if not great, was at least respectable. I entrust these articles to your honesty as well as your loyalty. As soon as I know that they have reached your hands, I shall feel that they have escaped the disaster which has destroyed the city, and are therefore in safety." If the jewels and silverware could be converted into specie and the money put to work it would be a great consolation.

From his friend Bentalou in Baltimore came a letter enclosing one from M. Poncignon, a Cape correspondent. "Like everybody else" he has "been forced to escape and seek a refuge here, and has even been cruelly forced to abandon his wife. He has just learned she has embarked on the same vessel with M. Aubert, in order to join him here, and I infer it must be one of your vessels. But however that may be I entreat you in the name of the friendship existing between us, to make every effort to discover when she arrives and give her all the help she may need both in money and in other ways, and 
especially to put her in the way of coming here without delay and joining her husband."

From another refugee who was "forced to flee leaving behind all that I possessed in order to escape the sword with which we were being pursued," came an appeal for aid to return to France. "I had nothing but my watch which I was forced to sell to get some absolutely indispensable things. But it was not enough to enable me to realize my wish to go to Bordeaux and I therefore turn to you and beg you to write to me if you could possibly procure me a passage to that city on my furnishing a draft on La Vve Louvrier \& fils, my brother-in-law, who would certainly honor it on presentation." $\mathrm{He}$ had been living on the charity of the City of Baltimore which put him with others in a house and paid "our living."

By the middle of July thirteen ship loads of refugees had reached Baltimore. They were said to be part of a fleet of one hundred and thirty sails bound for the Chesapeake and bringing five thousand refugees. As soon as this was known a meeting of the men on Change was held and a committee, of which Bentalou was a member, was appointed to visit the ships, find out the number and needs of the refugees and report. The committee visited the thirteen ships and reported that on them were three hundred and fifty-one passengers, of whom one hundred were women and children, appealed to the citizens to open their houses to the distressed, and asked for contributions of money. In one hour eleven thousand dollars were subscribed. Many who had vacant houses made haste to loan them while others willingly took into their families women and children. Still the ships came and at the end of a week the Baltimore Committee reported the arrival of forty ships with a thousand whites and five hundred negroes, and more vessels coming. 
A gentleman at Annapolis offered two houses for two families each, would pay the cost of transportation from Baltimore and supply them with bread. Another at Charlestown sent a hundred dollars. The Patriotic Society at Newark called for money to buy shoes to be sent to Citizen Genet for the Cap Français sufferers. At Philadelphia, to which upwards of seven hundred and fifty had come, a Committee reported that four thousand dollars would be needed to send two hundred refugees to France, three thousand to send a hundred and fifty back to San Domingo, eight hundred dollars to give employment to a hundred mechanics for a month, four thousand four hundred dollars to help two hundred settle in the west, nine hundred to aid widows whose husbands perished in the massacre, and seven thousand five hundred dollars to meet contingencies. The appeal was heard and fourteen thousand six hundred dollars were subscribed. To this, in time, the Commonwealth added 2500 dollars.

M. Chauveau who, from Philadelphia, went to New York, was reduced to such penury that he was forced to borrow $\$ 80$ from Mr. Ferrers.

"I found letters from Bacon waiting for me at the post office and was very pleased to learn that you, as well as he, are in good health. My mind is not quite at rest, however, as I still fear that you may be attacked by the cruel scourge which has made such ravages in your city. I am afraid, I say, my dear Girard, that you may expose yourself too much in your frequent visits to the hospital. I can readily understand what a joy it is to you to minister to the unfortunate who are abandoned by all. It is a proof of the kindness of your heart; but at the same time you must think of yourself. You owe it both to yourself and to those who are attached to you. You are not the only one on the committee, and each 
member might take his turn at the duty you have undertaken and which is extremely onerous. Besides you need a little respite to attend to your affairs and to take the necessary rest. You would not necessarily, by so doing, give up your attendance at the hospital altogether. ***

"The arrival of my wife and son on this continent has exhausted all the means that I had with me, both for board bills and hotel bills and travelling expenses which are always very high." Therefore he had, through $\mathrm{Mr}$. Ferrers, drawn on Girard for 80 gourdes, and asked him to make advances on the sale of some coffee sent by Bacon and himself, as he was to spend the winter at Perth Amboy. Girard wrote Ferrers that it was true that he had received some coffee for the account of $M$. Chauveau, that he had sold it to Evans \& Hunt, that Mr. Evans had since died. and that Mr. Hunt had informed him the notes given for the coffee would not be paid when due. He had already advanced M. Chauveau " $£ 30 r$. 12.7. our currency," nevertheless Ferrers might advance $\$$ I 50 less the $\$ 80$ already given. Ferrers gave him $\$ 100$ in addition to the $\$ 80$, an act Girard approved.

Another refugee asked, "Has your vessel arrived from Le Cap, or have you any news of M. Aubert? A vessel which left Le Cap on the $4^{\text {th }}$ instant has reached this port. The passengers were robbed by the people of Providence, and no other news from San Domingo than we have here. It appears, however, that the Commissioners have appointed a new municipality at Cap Français. M. Rouge is mayor and his clerk is the attorney of the sindic. Some of the municipal officers are citizens of their own creation, that is to say slaves. They have sent to France six commissioners, two whites, two mulattoes, two negroes, to make a full report on recent events, and from their version it appears that the merchants paid the sail- 
ors to set the town on fire in order to escape paying their debts. Is not this an atrocious piece of villainy on their part if the news is true?"

"Last night," wrote Hourquebie from Baltimore, "a government brig arrived in the roadway from Port-auPrince, which she left on the 6th or 7 th of this month, and reports that when she left there was a frigate from Aux Cayes in the bay. The brig also reports that owing to a proclamation of the Civil Commissioners she was not allowed to enter the port of St. Marc, and that about 800 sailors and other whites were confined in the prisons of Port-au-Prince. This piece of news would seem to indicate that the Civil Commissioners desire to break off all relations with the French Republic, if it is true, as the government brig reports, that all the ports of San Domingo have been closed to the war vessels of the Republic."

"I am here in search of a vessel for my wife and daughters for any port in New England, preferable your city or Baltimore-but I have not yet succeeded in finding one," wrote M. Jacques Mangan from Saint-Marc. "The places are engaged as soon as the vessel unloads, but I hope with patience and by diligent search to succeed in finding a vessel. The funds in your possession represent the only means of subsistence I have. Our plantations are in revolt, or I mean our slaves, and we are cut off from communication with our property. All the roads are closed, and strong detachments of troops are sent daily in pursuit of the slaves. We hope to be reinstated on our plantation before long with what negroes we have left. Our situation is most cruel."

"I shall not give you in detail the news about this colony, me dear sir. The cup of our misfortunes is full and we are daily harrassed in spirit by the most over- 


\section{THE LIFE AND TIMES OF STEPHEN GIRARD}

whelming anxiety and the most horrible forebodings," wrote one from near Port de Paix. "One has to be a husband and father to stay here at all."

M. Divissé who reached Charleston sent a draft for Girard to collect. "Please remit to me by the next mail, for I arrived here almost naked, with my wife and children whom I saved from Le Cap, after the unhappy affair of the 2oth of June, in a schooner which brought me to Gonaive. From Le Cap I went to the Môle and left there on the 2oth October last, one month after its capture by the English, reaching here on the $5^{\text {th }}$ day of this month (November) under the French flag without meeting any hostile sail during the voyage.

"The draft which I enclose (5280 livres money of San Domingo) and the schooner which I bought here, are the only resources which I have left after 26 years of labor in San Domingo, to support my wife and five children, four of whom are in Bordeaux." The draft was sold and the money, $\$ 622.50$, remitted.

"During my stay at the Island of Tortuga," said Adrien Nicholas Delasalle, Fieldmarshal and Acting Governor General of the Windward Islands, "with my friend Labatut, the despotism of the Civil Commissioner Sonthonax forced me to flee and seek a refuge in the United States. According to agreement M. Labatut gave me a bill of exchange on you for twenty livres tournois payable eight days from sight. On my arrival at Philadelphia the San Domingo refugees, thinking I was a partisan of the Commissioners, insulted me and so threatened me that I was forced to seek refuge in the house of the representative of the Ambassador. As I was forced to leave for New York, I gave him the bill of exchange on you, requesting him to send me the amount as soon as possible. He wrote me some time since that you 


\section{GOOD FRIENDS EMBARGOED}

requested a letter of advice from the drawer. This precaution is not customary in France and in the haste of my departure and not wishing to involve him in trouble with Sonthonax, it did not occur to me that I would need anything but the bill of exchange in order to draw the amount."

The arrival of the Polly at Le Cap soon after the three dreadful days of plundering, burning and murder, and her return to Philadelphia with eight and thirty refugees gave rise to a story concerning Girard, which one of his biographers, Mr. Henry Atlee Ingram, thought necessary to tell and refute.

"The year 1793 witnessed the horrible uprising of the slaves in the island of Santo Domingo, and many foreign merchants narrowly escaped sharing in the general massacre by taking refuge on one of Girard's vessels, commanded by Captain Cochran, then in port at Cap Français. Some of these refugees barely escaped with the clothing upon their persons, but others, more successful, saved large quantities of wearing apparel, household furniture, and silver, with which the vessel set sail for Philadelphia, where she arrived safely, loaded with the valuables. It has been said that Girard's fortune was largely increased by the subsequent failure of owners to claim many of these articles, but no reliable evidence has ever been adduced, while both Captain Cochran and Mr. Roberjot, one of the refugee merchants, who succeeded in saving nothing but a valise of valuable papers, vouched personally that all for whom articles could be found had been returned."

Letters from Aubert, during July and August tell what really happened.

"By this opportunity (July 30 1793), you will learn of the arrival of the French Convoy in Virginia, and that 
certain vessels have gone to Philadelphia which will inform you of the disaster that has overtaken our city. The news will be fully confirmed by the passengers who are leaving here every day in large numbers to go to the continent, and it would be difficult to say which I think is the most unfortunate. The misfortunes we have gone through are beyond conception. Surprised in our houses by murder and incendiarism, the only hope of safety was in flight. Even in the houses that were not burned down and entirely looted, papers, books and all office furniture were thrown into inextricable confusion so that it is impossible to recognize a book or a paper. It will take a great deal of time to restore order and to find such important documents as the receipts of the Administration for the flour from your shipments which we received just before the outbreak and which we will need in order to receive payment in the general disorder which prevails."

The sum due the Polly was 38,450 livres.

"I shall take the greatest precautions to guard against the Polly's cargo being compromised. There will be very little freight in coffee entered as cargo. The passengers' effect such as body linen are partly packed in barrels which are merely marked but have no bill of lading, so that in case of visit and search, you will run no risk. When I see you I will give you exact details in regard to everything. This is the last and only time I shall write you concerning this matter. $* * *$

"What is delaying her departure so long is the scarcity of commodities which the Administration is expecting for I do not wish to leave anything behind. But what trouble this makes for the 30 passengers who are living on board at their own expense."

Who these passengers were is explained in a letter from Captain Congdon, August 4th, 1793. 
"All the vessels that goses from this to America takes a great many passengers, but Mr. Aubert will not allow me to take any but his family and they have been aboard 4 weaks. Thear will be between 30 and 40 of black and white."

"The Polly," Aubert wrote August 5th, "has now been more than a month in our roadway, and cannot stay much longer, from what Captain Congdon tells me, as you may be obliged to have her careened on her return. This latter consideration, the constant outlay, the annoyance of almost 38 passengers, both whites and their servants, who are on board the vessel, may render an earlier departure of your vessel absolutely imperative."

August 2oth the Polly sailed from Le Cap and twentyfour hours later was a prize.

"By a New England schooner which left Le Cap on the 9th of August and arrived here on the 6th instant" (September), he wrote Bacon, "I hear that they left the Polly at Caicos in possession of two privateers. But since then I have learned that this brig Polly is another vessel, commanded by Captain Quandrill. Nevertheless $\mathrm{I}$ am anxious about M. Aubert. $* * *$

"P.S. Just as I was about to seal my letter I hear that the brig in question really is my brig Polly, so that our esteemed friend M. Aubert, will be plundered, and may account himself fortunate if he is not carried off to Providence."

A Baltimore house was now requested to "please tell Mr. Chauveau that I heard by a schooner which left Le Cap on the Igth of last month (August) that on the 22d she left my brig Polly, Captain Congdon, at anchor at the Caicos with a privateer of ro cannon from Providence. Our respected friend M. Aubert has accordingly been robbed in all probability (as well as the rest 
of the passengers) and he will be lucky if he is not taken to one of the ports belonging to these brigands."

He was not mistaken in the belief that the ship and passengers would be taken to Pravidence, from which port M. Aubert wrote: "On the 2Ist we were stopped, or rather your brig Polly was stopped, by two privateers one from here and the other from Bermuda. After searching the vessel and the belongings of 36 unfortunate passengers, among them my wife, myself and my family, the first privateer sent us here in charge of an officer and some of his crew. Captain Congdon stayed with us and we feel very sorry for him because of the interest he took in our misfortune. We do not know how long we shall stay here. The Polly is leaking very badly and will have to be unloaded in part so as to have her seams recalked. Her cargo consists of 18 hogsheads of sugar and 13 hogsheads of coffee costing 33668 livres 9 sous, given by the administration which still owes the Polly 22604 livres, 16 sous. being unable to pay that amount because of lack of commodities and the vessel in a hurry to sail.

"In addition there is some merchandise loaded on board from certain old friends of yours, ro barrels of coffee and a quarter hogshead of white sugar, all for your account. The passengers permitted me to put into these barrels their money, jewelry and other precious belongings which, however, was disclosed by a man belonging to the crew and by a hint from the servants the privateer had taken on board his vessel. I fear more for the safety of these articles than for that of your property. I find my wife and family stripped of their last resources."

On the fifth of September Aubert wrote again giving full details. The privateer was called the Sally, Captain Gante. "The most important articles belonging to 
the passengers with the exception of their clothes were kept by the Captain of the privateer who sent them to his owners. The vessel was searched repeatedly. The sailors who were put on board as a prize crew carried on their search most vigorously and almost wrecked the Polly in their examination of the cabin, store rooms and hold. Pirates could not have done worse. The value of passengers' property amounts to a hundred thousand livres and the loss of my belongings deprives me of every resource. In the position in which I find myself and family, without a gourde at my disposal, I am obliged to borrow one hundred gourdes from Captain Congdon who promises to let me have them in return for my promise to repay him with your help, which I shall ask for as soon as I reach Philadelphia. I therefore beg you in advance to help me. I will give you valuable securities which will assure your being paid back all the money you may give me." Little did he think, he said, that after forty-five years at Le Cap, during which time he had amassed a fortune of 3,000,000 livres, he should be forced to sail about the ocean and trouble his friends for money. After a strict examination at Nassau the cargo of the Polly was adjudged to be property of a citizen of the United States, and the vessel was released. What became of the silver and jewelry concealed in the coffee and sent by the Captain of the privateer to her owner is not known. If returned, these precious articles were undoubtedly claimed by their owners who came with them in the Polly. That silver and jewelry were sent to him by other ships there is no record whatever. That such shipments, hidden in coffee or sugar, were carried by other ships to other merchants, and for some reason never received or never accounted for is quite likely. Be this as it may the story in time took a new form and one day in September I824 a gentle-

Vol. I-14 


\section{THE LIFE AND TIMES OF STEPHEN GIRARD}

man called at the Counting House and presented a letter which was copied and returned without written comment.

Liberté

République d'Haiti

Egalité

Port au Prince, le 2 Aout 182

au - de L'indépendance

Le Sécretaire D'Etat

Au citoyen Jonathan Granville, agent du

Gouvernement à New York,

Citoyen:

"During the years 1792 and 1793 when the terrors of the Revolution and dissensions of Commissioners Polvered and Sonthonax with General Galbaud covered the City of Cape Haytien (Cap Français) with flame and with mourning, a considerable number of persons, both Europeans and creoles of the country, thinking only of saving the best of their possessions from the fire by placing them on board the vessels lying in the roads of the Cape, consigned them to Mr. Stephen Girard, whose reputation was well known, but as the greatest confusion prevailed during those troubled times it was impossible to follow the usual method of making shipments. Some of the shippers fell victims in the fights which occurred, leaving unhappy heirs. Others escaped, but the greater number of those unfortunates recovered nothing because they had no opportunities to obtain receipts entitling them to withdraw the goods from Mr. Girard, and there is a considerable amount in jewelry, silverware and other valuables which formed the bulk of these shipments, still unaccounted for.

"Since peace was re-established and the families have joined together to collect the debris of their fortunes, a great many of our citizens, remembering the money and valuables which their parents sent to America, are seeking some way to claim them, which as legal heirs 
they have every right to do. But as they have no title the government of the Republic necessarily becomes their representative and believes itself bound to make these claims, if not for the full value of the shipments which were made, for at least one half. It is evident that a large part of that deposited in Mr. Girard's hands belonged to the Haytians of Le Cap, who enjoyed, as is well known, very great wealth.

"As I have just been informed that French people have sent claims to Mr. Girard for the full amount of money, jewelry and other valuables now in his possession, although they have no better title to confirm their claims than the Haytiens, and have received orders from His Excellency, the President, on this subject, I therefore authorize you by the present, to interview Mr. Girard, Banker in Philadelphia, and to inform him of the claims you are empowered to make in favor of the Haytians.

"If any difficulty arises in the settlement of this business you will advise me of it. In this case the best method of settling it will be to have the differences decided by a committee of arbitrators.

"As to the rest you are on the spot. Interested as you are in all that concerns the Republic, you will neglect no means of obtaining the most full and complete information concerning this affair, on which to act. I salute you with perfect consideration."

There were no such shipments. No demands were ever made by "French people" on Girard; none were ever made by any Haytians; "Citizen" Granville took no steps to carry out the orders of His Excellency the President of the negro republic, for there was no silver and jewelry to reclaim, and with the delivery and return of the letter the matter ended. 


\section{CHAPTER VI}

\section{CAPTURES OF THE KITTY AND THE SALLY}

WhILE the people of Philadelphia were pouring out their money to help the refugees from San Domingo, they little thought that in a few weeks' time their own city would be a scene of desolation. Long afterwards it was customary to say that the refugees brought the yellow fever. However this may be, the disease first appeared at Kensington, whence it spread through Philadelphia with a rapidity that baffled the medical skill of the time. During the first week of August as many as five died each day. For the second week the daily average was seven. But during the third week the fever became virulent, the streets were black with funerals, and the church bells tolled incessantly. Thousands of citizens turned the keys in their doors and fled to distant towns and villages. Such as remained were cautioned not to get tired, to keep out of the sun, to mark the doors of infected houses, to bury the dead as quietly as possible and above all to stop the ringing of bells. This advice was readily taken; hearses no longer were seen in the streets; the bells were silenced; the dead were quietly carried to their graves at night and bonfires were lighted at the street corners to purify the air. When the doctors declared they had no faith in bonfires and much in gunpowder every man who could secure a musket made haste to do so and discharged it all day long. But the musketry produced such depressing effects on the sick that the doctors ordered it stopped and nitre was burned instead. Any remedy the wit of man could suggest found eager users. Now it was mud baths, now tobacco, now garlic which the timid chewed, carried in their pockets and put in their shoes. Now it was 
camphor and soon all who could had a bag of it hung around the neck.

Such preventives were far beyond the means of the poor. Shut out of the Alms House they were hurried, when sick, to the circus. But the circus was near a well settled part of the city and the people made threats of burning the huts unless the sick were removed. The Guardians of the Poor then selected as a pest house the residence of $\mathrm{Mr}$. William Hamilton at Bush Hill; the Governor and the Mayor approved their action and, as Mr. Hamilton was not in town, a letter addressed to him, telling what had been done, was published in the newspapers early in September, 1793.

By the first of September, mention of the fever began to appear in Girard's letters. "How are you in Baltimore?" he asks of Changeur \& Co. "As for myself I am not fortunate enough to possess good health, and although I am not frightened I cannot look with composure on the ravages of a malignant fever (which our Esculapians treat as a plague) which daily carries off my neighbours, though I must say I think the disease is beginning to subside." To his friend Bacon who had escaped from Le Cap and was then in New York he said: "No news of M. Aubert, nor of my brig Polly. It seems as if the misfortunes at Cap Français will be fatal to me. I really dred to see vessels arrive which were at Le Cap before and after the Polly, and which have sailed thence of Port de Paix, Jean Babel, the Môle, Gonaives, St. Marc, and all have made good voyages." * * *

"Probably you have heard it said that the plague has broken out in Philadelphia. I beg you will not believe this. It is only a malignant fever which, by the pernicious treatment by our doctors, has sent many of our citizens to another world." 


\section{THE LIFE AND TIMES OF STEPHEN GIRARD}

"I received your letters of the 25th (August) and 26th, which I would have answered sooner," he wrote M. Hourquebie at Baltimore, "if I had not had a slight attack of the fever which is daily carrying away numbers of the inhabitants of our city. The mortality has been so great and the panic so general that it has not been possible to find nurses to take care of the sick, or men to bury the dead. It is to be hoped that the month of September will bring all the inhabitants back to their homes and that business will resume its usual trend."

When Messrs. Changeur \& Co. of Baltimore requested him to effect insurance on the cargo of a vessel from Baltimore to Saint-Marc and Port-au-Prince he answered:

"I presented myself at the underwriter's office. The agent answered me that it would be impossible to insure just now to the amount of 8000 piastre gourdes at Philadelphia, because nearly all the underwriters have left town and the few that remain are afraid of the epidemic which has made fresh ravages."

"The epidemic prevailing in our city is increasing rather than diminishing. Since Sunday last 80 inhabitants have died and this added to the large number who have gone to the country, renders the condition of those who remain truly deplorable. If the disease continues two weeks longer, there will be nobody left here but Frenchmen, for they do not die so easily."

He believed that "the deplorable condition to which fear, fright and disease have reduced the inhabitants of our city claims the aid of all those who are not afraid of death or at least who do not see any risk in the epidemic which appears to prevail. I shall accordingly be very busy for a few days and if I have the misfortune to be overcome by the fatigue of my labors I shall have the satisfaction of having performed a duty which we owe to one another." 
September roth, the day before this letter was written, a call for help appeared in the newspapers. Overseers of the Poor, it said, were almost overcome with fatigue and required immediate assistance. Volunteers were needed, and all who would help were asked to apply for information to the Mayor.

On the 12th, as the result of this call, a meeting of citizens was held in the City Hall and on that occasion Girard and nine others offered their services to the Overseers. A Committee was asked to report on the condition of the sick and poor in the city and vicinity, and to confer with the physicians who attended the sick at Bush Hill. Of this Girard was a member, and that evening reported that the Overseers of the Poor were wholly unable to cope with the work they were called on to perform, and recommended that the citizens be called in town meeting, on the

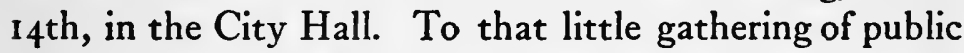
spirited men the Bush Hill Committee stated that a steward, nurses and money were needed, and that a large committee of men from the city, the Northern Liberties and Southwark should be appointed with full power to act. Thereupon it was voted to borrow $\$ 1500$ from the Bank of North America, and a committee of twenty-six, of which Girard was one, was chosen to transact all necessary business. This body organized at once and appointed ten men, of whom Girard was one, to take charge of Bush Hill Hospital. Care was badly needed. There was no system, no organization, little attendance on the sick. Doctors Physick and Leib visited the Hospital once a day. But the sick were coming in at all times and lay unattended till the physicians came again. A superintendent, a resident physician, some well paid nurses, order and system must be had at once.

September 16th, therefore, Girard and Peter Helm 215 
volunteered to act as Superintendents, and Doctor John Deveze, a refugee from San Domingo, was secured as resident physician. All this seemed most irregular to Doctors Physick, Leib and others, and they now declined to go any more to Bush Hill. Thus left in full control, Girard, with Helm to help, managed the hospital till it closed. The committee met every day; but the minutes show that from September 18th to November 16th Girard and Helm were not in attendance. On the minutes of each daily meeting after the list of those present are, invariably, the words, "Stephen Girard and Peter Helm at the Hospital."

In November work at Bush Hill became less exacting, and Girard once more attended the meetings and between that time and the closing of the hospital served on eleven sub-committees. Not till January 18th, 1794, was he able to close the building and deliver the keys to the Chairman of the Committee.

Constant occupation at Bush Hill left no time for what little business could be done. His correspondence almost ceased, and complaints came from friends and business associates. To one who wrote from Princeton, New Jersey, whether he had fled, Girard answered :

"I assure you that I was greatly affected by the contents of your letters. It is probable that certain evil disposed enemies of people's peace of mind as well as their liberty, have given you absurd reports about what they call the epidemic, or plague, now prevailing in our city. I must ask you to disabuse your mind of everything you may have been told about this matter, and to believe me when I say that by leading a regular life it is quite possible to live here in good health."

"What is the reason for your silence, my dear Girard?" asked Bentalou. "Two mails have already passed with216 
out my receiving any news from you. Why this indifference? If you have the good fortune to have escaped the awful calamity with which your city is attacked, or if you have left the city, why do you not let me know; your silence fills me with grave fears on your account. If they are not well founded reassure me by sending to the firm by every mail these four words " $j e$ me porte bien.'"

"So terrible," said Ferrers, writing from New York, "have been the late accounts from your unhappy city that I have feared illness may have been the cause of your not writing, but I will hope it has arisen from your time having been engrossed by the Benevolent Associations in which you are engaged." The most persistent complainer was Changeur \& Co. who had applied to Girard to effect insurance on a ship and make them a loan. To them he replied, "The duties imposed on me in my capacity as a citizen prevent me from answering at the proper time the letters written me by my friends."

When the insurance was obtained in New York and they wrote for the account he replied:

"You ask me for an account of the insurance which I have placed on your account. I cannot possibly send it to you just now. It seems to me that the condition of our city offers a sufficient excuse for the neglect under which the affairs entrusted to me have suffered lately, without having the annoyance of receiving reproaches by every mail. Besides, Gentlemen, my private affairs, which are of a good deal of importance, are also suffering much. I have to devote myself to the public welfare and whenever I have a moment to spare I spend it in looking after your interests."

Late in October he sent assurances that business was improving and the fever abating. "The epidemic which has been visiting us for some time has greatly diminished 
and our fellow citizens are accordingly beginning to come back to their hearths." He would send the accounts for the insurance he had effected "as soon as I have a moments time to devote to the matter."

"We are sincerely glad of this," was the reply, "for it is high time that you put in order various matters which you had forgotten or omitted to attend to on account of your numerous occupations."

"I received yesterday a letter from my good friend Bentalou dated the 20th inst. in which he expresses great anxiety on account of my silence. It seems to me that I have written to you whenever matters demanded it, and if I have missed a few mails it is because of the great mass of work I have to do in connection with the hospital we have opened at Bush Hill, of which I am a director. The disease has not made the slightest impression on me, but I must confess that I am a little tired."

Among the few to whom he did find time to write was Samatan. "A malignant fever which has prevailed here for the last month added to the ignorance of our doctors and the fright of our people has carried off more than 4000 of our friends. Mr. Thomas Lea and other merchants of the first order are among the number. In short we are all in a deplorable condition. Those of our citizens who escaped this scourge have left their hearths, almost all our houses are closed and Philadelphians are not admitted to neighboring cities until they have been quarantined. The few inhabitants who have the courage to remain have established a hospital at a short distance from the city for the reception of the unfortunate victims. I am an active director of this hospital and my duties connected with it give me a great deal to do."

"It is now the 3oth of September. Poor Mr. Delmas, who came here in the brig LaCouronne died yesterday 
at ro o'clock in the evening after three days of fever. I do not know when our misfortunes will end. I am off now to the hospital where so many sick are received daily that my presence is constantly demanded."

Just at this time two vessels, the brig Polly and the sloop Abigail, consigned to Messrs. Changeur \& Co. arrived from Bordeaux. On the Polly, Girard informed the Baltimore house, "you have a young Irishman from your firm in Bordeaux." This man was Peter Seguin, sent out by the Bordeaux house of Pre Changeur to be an apprentice to the Baltimore branch and learn the business. From the day he left Bordeaux till almost the day of his death in the home of Girard, Seguin kept a diary which throws not a little light on the home life in Water Street at this time.

After entering day by day all the incidents of the long voyage and the sail up the Delaware he continues, "Monday, 3oth September, I793. We arrived at Philadelphia and I went on shore to get some fresh bread, and went about a quarter of a mile from where we ly'd and then arrived at an old Baker which lisped so bad that he was an hour Before he could tell me he had none, and I asked him where I could get any and he told me there was some next Door, and so I went and there found a very ugly woman and $i$ asked her whether she had any Bread and trying to put a smile on her face she answered, yes, and i Bought from her 8 four penny loaves, which makes 2 shillings and 8 pence."

"Wensd. 2 October I793, the passengers Beg'd of me to go to market with the cook, Because he could not speak English so i did, the Market is in the middle of the town and is a mile long and the people is all covered as the cant be wet \&c. as we were bargaining 3 french men stop me and ask me whether $\mathrm{i}$ had any letters, and $\mathrm{i}$ 


\section{THE LIFE AND TIMES OF STEPHEN GIRARD}

answer no, and he ask me in what vessel $i$ came in, and i answer the Polly from Bordeaux, and he ask me to ho the vessel was addrest to and $\mathrm{i}$ answer'd to $\mathrm{Mr}$. Changeur fils, Deyme \& Co. in Baltimore \&c. and he said he new them very well, and he said the was seperrated and that the were 2 Different housses and he told me that it was Mr. Step. Girard that represented them in Philadelphia in north Water street No 33-about 6 o'clock $\mathrm{i}$ went to Mr. Step. Girard and told him the polly and the abigail was arrive of $\mathrm{Mr}$. Changeur fils Deyme \& Co. and that I belonged to the house in Baltimore, and he told me that he could do nothing but wright to them and he said we must whait for their answer \&c. and he said that if $i$ wanted anything that $i$ had his house and table, and $i$ occepted it, and he Bid me come to dine with him and so i did \&c.-about 3 o'clock we dine and we had some Brough and a piece of boiled Beef and some Beef Stakes, and some sweet poetattys and a few pairs and Bread, and he gave us a glass of moddery after dinner, we was 5 at the table, Mr. Girard at the head, and his two boys at the foot, and his house keepper at the side and $\mathrm{i}$ in face of her, at night $i$ went to walk with one of the young men and to make acquaintance with a young Girl which lives in south sixk street. and at 8 o'clock we come home and has the dont sup until 9 o'clock we had an hour to wait." For supper when it came "we had tea and bread and butter." That night young Seguin slept in the "garrot" with the two clerks, rose the next morning "at 5 o'clock with the 2 Boys and went down to the where house and about 8 o'clock the call'd us up to Breakfast and we had coffee and Bread and Butter."

Thus quartered in Girard's house Seguin while waiting for a vessel bound for Baltimore rendered such service as he could in the warehouse till the roth of October when 
he too fell a victim to the plague. Writing on the I th to Messrs. Changeur \& Co. Girard remarked "Mr. Seguin, your young Irishman has had a high fever for four days. I am his doctor, and although he is constantly delirious, I hope that the treatment, a grand lavage, with the strength of his constitution will enable him to go to you on the Abigail." He was not to go on the Abigail. Two days later Girard reports, "I am very sorry to have to tell you of the cruel turn in your Mr. Seguin's sickness during the past two days. Two days ago I called in Dr. Deveze, the senior doctor in our hospital, who makes me fear for the life of the unfortunate young man. As he is in my house you may depend upon it that every possible care and attention will be given.

"It is unfortunate that your vessels (the Polly and Abigail) arrived at such a time. The disease and the panic which it has produced among my fellow citizens have seriously interrupted business of all kinds. I do not know when we shall see the end of it. I am neglecting every sort of business and devoting all my time to helping the unfortunate victims. It is now one o'clock in the morning and part of the past two nights I have spent at $\mathrm{Mr}$. Seguin's bedside."

That same night writing to Bentalou he said: "It is half past four in the morning. The sleepless night I have just passed, my constant fatigue, and the fact that my health is none the best combine to forbid my writing you at great length.

"You may depend upon it, my dear friend, that the condition of the people of our unfortunate city is the only reason why I have not kept up my customary exactness. As soon as things have quieted down a little you may be sure I shall take up my work with all the activity in my power. But, for the moment, I have devoted all my time 
and my person, as well as my little fortune to the relief of my fellow citizens.

"Poor unfortunate Seguin is in a very sad condition since he has had plasters applied which took singularly well. He has fallen into a profound state of collapse which causes me the liveliest anxiety." The next morning he died and was buried in the Catholic cemetery.

In a circular issued by the firm of Samuel and Miers Fisher to their correspondents on November I8th, the work of Girard and Peter Helm received its first public recognition. After describing the spread of the fever, the panic, the abandoning of the sick to the care of negroes, and the flight of people from the city, the writer continues, "A number of citizens however, with a courage that will always do them honor, formed themselves into a Committee headed by the Mayor; borrowed money on the credit of future subscriptions; established an hospital, about a mile from town, for the poor; procured carriages to convey the sick to it; sat daily at the City hall to receive applications and administer relief; and two of them, Stephen Girard, a French merchant long resident here, and Peter Helm, born here of German parents, men whose names and services should never be forgotten, had the humanity and courage constantly to attend the hospital, and not only saw that the nurses did their duties, but they actually performed many of the most dangerous, and at the same time humiliating services for the sick with their own hands; these gentlemen are mercifully preserved alive and well, though four of the Committee who sat at the City Hall took the disorder and died-their names were Daniel Offley, Joseph Inskeep, Jonathan D. Sergeant and Andrew Adgate."

Those who staid in the city, the circular states, "were cautious how they went about the streets, so that the city 
in a degree seemed to be depopulated; business of almost every kind was suspended; inward bound ships came to at the villages down the river, and for nearly two months our streets were deserted by all, but a few sorrowful persons walking, as with their hands on their loins, about the necessary concerns of the sick, and hearses conducted by negroes, mostly without followers, to and from the different grave yards."

Jean Deveze wrote a narrative of the "epidemic," in which he says of his friend, "Souvent même $j$ 'ai vu les malades, rebutes par le mauvais goût des médicamens, les rejecter et en couvrir leur bienfacteur. Que faisait alors le vertueux Girard? * * Il essuyait le moribond, l'exhortait au courage, il revenait à le charge, et à force de persuasion et de patience il pervenait à faire avaler le remède * * avant de le quitter pour passer à un autre, et lui prodiguer les mêmes soins, il lui touchait les pieds, le front, afin de connaitre le dégré de chaleur et faire, suivant les circonstances, augmenter ou diminuer les nombres des couvertures."

At the seaports along the coast sloops and brigs from Philadelphia were quarantined. Some towns forbade stage-coaches from that city to pass through them; others put up rude huts on their outskirts and forced travellers to be examined before they were suffered to proceed. Armed guards at the ferries kept back suspected persons. Inn keepers admitted no travellers who came from Philadelphia. The health authorities at Baltimore, Trenton and New York posted hand bills forbidding communication with Philadelphia. In one proclamation the Governor of New York forbade ships from the pest-ridden city to come nearer than Bedloe's Island; in another he appointed a day of fasting, humiliation and prayer. A meeting of merchants begged the proprietors of southern 
stage lines to cease running their coaches; owners of shallops that plied between New York and Paulus Hook, as Jersey City was then called, were requested to land all passengers between sunrise and sunset, and the citizens were cautioned not to take strangers into their houses.

Day by day in Philadelphia the death rate climbed till on October I I one hundred and nineteen died of the fever. Not till the close of November did the citizens feel safe to return. By that time four thousand and forty had died of the fever. Of all the sad sights of those dreadful summer months, the saddest was that of little children, orphaned and homeless. One, half dead from starvation, was found in a deserted blacksmith shop. The Committee, as soon as it was organized, came to their relief and thirteen were cared for in a rented house. But the number grew from day to day and the building once used by the Loganian Library was taken as a shelter for sixty. Wet nurses were found for forty more. In all over one hundred and ninety four orphans were fed and clothed.

The Kitty commanded by Captain William Waters put to sea in August. His instructions bade him sail to Jérémie in the island of Hispaniola and there sell his cargo, valued at $£_{4088,95}$. I I $d$. Pennsylvania currency, for cash or in barter for coffee and cocoa. Should the captain, on arriving at Jérémie, think it unsafe to remain in port because of the hurricane months, he might go to Cayemite, or if disturbances existed at either or both of these places he might go to any port in the island he thought safe.

A tedious voyage of five weeks, due to head winds, calms, and detention by British privateers brought the Kitty to Jérémie on September I 3 th. So many American vessels had arrived before her that flour had fallen to five dollars a barrel, and what was worse the Captain was not allowed to seek a better market elsewhere. "But the 
Executive Council of the quarter, viz. Jérémie, Caymite, Abricote and Cape Dame Maria, who are opposed to the Commissioners Sixtanax et $\mathrm{Co}$. have demanded the greatest part of the Wine, Oil, Soap, Butter \& Lard which I have on board and should they pay me as I am informed they have some other Americans it will be very Different from what I wish. I should immedrately proceed to some other part of the Island but cannot get permission."

Mr. John Ducornau, formerly a clerk with Hourquebie frères, was supercargo on the Kitty and from himcame a fuller statement.

"This town has formed a confederation with three adjacent parishes, the Cayemites, Abricote and Cap Dame Marie, and refuses to acknowledge the authority of the Commissioners, \&c., or submit to the proclamation the latter has issued, by virtue of which slavery is greatly alleviated and practically abolished in the rest of the colony, a proclamation which makes the existence of the whites who remain very precarious. In this dependency on the other hand they continue to keep their negroes on the plantations. All communication is forbidden between this dependency and the remaining districts. The prospect is not brilliant here for Americans loaded with flour, for that article is very abundant and is worth but from 5 to $5 \frac{1}{2}$ gourdes."

After a delay of five days the Captain at last obtained permission to sell, but that "same day arrived a brig from New York with wine, provisions, \&c., which hurt the sales of my cargo-on the I9th there anchored here a British fleet consisting of one 50, 2 Frigates, 3 Arm'd Schooners, and 3 Transports on the 20th they landed $55^{\circ}$ Troops \& the British flag was hoisted at the diffnt Forts; the particulars respecting the Capitulation $\mathrm{Mr}$. Ducornau will inform in his letter-the change of Government taking

Vol. I-15 225 
place seems to have put allmost a total stop to trade, however I have sold about one third of my cargo \& purchased Io thousand wt of coffee-I have just been informed from good authority that if the Americans now here does not get their vessels cleared for the continent in Io days they will not be permitted to carry away coffee."

Captain Waters had reached the Island just in time to witness the beginning of the English occupation. No sooner had France declared war on Great Britain in February, 1793, than General Williamson, commander-inchief in the Island of Jamaica was instructed to send a force sufficient to hold such places in San Domingo as were willing to accept British rule. September 19th accordingly British troops from Port Royal appeared before Jérémie, landed and occupied the town. Three days later a British ship with a hundred grenadiers on board appeared off Môle Saint-Nicholas which at once surrendered. Saint-Marc,Léogane and other parishes yielded before the year ended. In February 1794 Cap Tiburon was taken by storm. In June, whites from Léogane and Saint-Marc, aided by a strong British squadron, captured the city of Port-au-Prince, and Sonthonax and Polverel who had fled to the negro general Rigaud at Les Cayes, sailed for France in obedience to a summons from the Assembly.

Mr. Ducornau, as the Captain said he would, reported that the day he received permission to sell, a brig from New York entered the harbor with articles the same in kind as the Kitty brought and that the next day a schooner from Philadelphia arrived with the English fleet also loaded with wine, oil, flour, soap. "This has created competition in a country where the consumption is less than it used to be because the inhabitants, most of whom are living in the camps, are not supplying their plantations with provisions and hope to be able to draw provisions more 
cheaply from Jamaica than from America. Such, dear Sir, are the difficulties we have to meet at the beginning of our sale. They explain why the amount of our sales up to the present day is not more than 27000 livres for which we have taken in payment 8,000 pounds of coffee.

"Coffee which is sold at 7 to $I I$ is not abundant in fine quality, and the increased shipments to Jamaica have already made a rise in price. You will see by Article 12 the Capitulation how American Commerce is to be restricted in this island. It seemed just that those who arrived here before the English should benefit by the French laws; but in spite of the principle, acknowledged by every nation, that laws cannot have a retractive force, it has just been decided that the loading of commodities will only be allowed for the next ten days, after which no more are to be exported. This decision will increase the price of coffee all the more as that in town added to what will be brought in during the interval will not be enough to load all the vessels.

"The Môle, like this dependency, is in the power of the English and 400 men are to leave here tomorrow to take possession of Tiburon."

October second the British Governor by proclamation gave permission to Americans in port before the capitulation to load with produce of the island, but they must depart within ten days.

Against this Ducornau protested in behalf of the Captain.

"To the members of the British Council at La Grande Anse.

Gentlemen.

Wm. Waters, captain of the brig Kitty of Philadelphia, has the honor to state that from the 2Ist of September 
until the $4^{\text {th }}$ of October, he made several deliveries to the Council, the statement of which as drawn up by yourselves on the 8th instant amounts to 5090 livres, 5 s.

"While the petitioner was attending to the sale of his cargo in this city you issued a proclamation to the effect that American ships would not be allowed to export merchandise unless they left the port of La Grande Anse within Io days.

"It seemed natural to the petitioner to conclude from these orders that he would be sure to be paid before that date. He therefore counted on it firmly and with equal confidence acceded to fresh demands made on him both for the hospitals at the Môle Saint Nicholas, and at the other camps in this dependency.

"At a great sacrifice he disposed of all his cargo, and the proceeds having been converted into coffee he presented himself at the end of ro days to collect your account and get himself despatched. But he was unable to obtain the funds and has no other means of settling for the duties he must pay.

"The petitioner did not think that he ought to apply to you at his first refusal because he knows that the methods of the magistracy are less rapid than those of private merchants, but five days have gone by and he is still in the same predicament and his vessel is constantly under a heavy expense. He therefore thought it his duty to present you with a clear statement of his position."

All other money save about $\$ 600$ due by the French government for wine it had taken, was collected and the Kitty was allowed to sail to the Cayemites.

"I had then about two thirds of my outward cargo on board \& not sold. The short time allowed us to do 
our business required every exertion, and here I cannot omit mentioning the activity of $\mathrm{M}$. Ducornu-in the Io days allotted us we sold and landed what cargo I then had on board and purchased and shipped about 85000 wt of coffee and $2900^{\text {wt }}$ of Cocoa which was all we could get on board without working almost day \& night. Altho I cannot give you a favorable account of my voyage, I can assure you we have done more business \& to better advantage than all the Americans besides who were so unfortunate as to be at Jérémie." At Cayemite he proposed to stay till paid by the Government and then go directly home, or stop at some other port in the Island to complete his cargo.

Nothing more was heard from the Kitty for many months. As time dragged along his anxiety increased and news of the missing ship was sought from every source available. 'In December M. Desulauze who had just arrived at New York from Jérémie was asked for news.

"I learn through the newspapers that the schooner in which you arrived came from Jérémie. On the I 3 th of October last $I$ had in that harbor a brig with a rich cargo commanded by William Waters and having on board as supercargo M. Ducornau formerly clerk with the firm of Hourquebie frères and as I have had no news whatever from the vessel, I will ask you to tell me whether you know anything about her."

M. Desulauze at once replied, "When we left Jérémie your brig was not in the port, and probably had already sailed. I am well acquainted with M. Ducornau, believe him to be a very correct man, and am surprised that he neglected to inform you about his voyage." January I794 he wrote his old friend Chauveau, then at New York: "I am anxious about the fate of my ship which I am ex- 
pecting from Bordeaux and that of the brig Kitty which must have left Jéremie for this port on the roth of last month. These two vessels represent more than one hundred thousand piastre gourdes to me, but what am I to do? I suppose I shall have to be patient and wait for better times with what firmness I can command."

In February he wrote a Baltimore correspondent. "I have received the affecting news that the brig Kitty which I was expecting from Jérémie met a storm off our coast which forced her to cut down the mainmast and run for the islands."

This was true. On the third of November Captain Waters set sail for Philadelphia, and on the 2Ist, off the Carolina coast, ran into a gale, was forced to cut away his mainmast and make for the Windward Islands, and just as he came in sight of Guadeloupe, was captured by a French privateer and taken into Basseterre. "What then happened is told in a letter Captain Waters wrote at Montserrat on the 9th of February: "When my troubles are to end or when I'm to get home god only knows, you no doubt will be very much surprised when I inform you of the Condemnation of your briga Kitty \& Cargo which has taken place at Basseterre in the island of Guadalupe where I was going to refit my vessel to proceed to Philada ${ }^{2}$. On the $9^{\text {th }}$ of January I was boarded by a French Privateer when the vessel was taken from me by force, Ioth was anch'd in Basseterre Roads \& myself, M. Ducornau and all my people sent to the Common Goal; we were all confined until the Condemnation of the vessel \& Cargo took place which was about the 2oth of January. The General \& Intendant has wrongfully accused me of supplying their Enemy with provisions, and on that principle (contrary to the opinion of the Judges \& National Commissary) has confiscated the vessel \& Cargo-in short I have been most 
cruelly robbed of everything in the world even to a second shirt \& my watch \& had not Captain Art who had heard of my misfortunes been so generous as to stop with his ship \& take me on board, god only knows what would have become of me being left destitute of a Friend or a Farthing of money. I am extremely unhappy to inform you that Captain Congdon on the Brig Polly will undoubtedly share a similar fate as the English Captures every vessel bound to or from a French port.

"I left Captain Congdon at Basseterre the 7 th Inst., who had sold about $1 / 4$ of his Cargo \& not likely to sell the rest. There are now 3 I American vessels at this place and are daily arriving as prizes to British Privateers."

All these facts were promptly made known to the underwriters and to the French Minister, Fauchet. The insurance was $£_{900}$ on the Kitty and $£_{2000}$ on the cargo.

His letter to Citizen Fauchet announced that

"On the 8th of August last I despatched my brig Kitty to San Domingo with a cargo of flour, \&c., under the command of William Waters. On the $13^{\text {th }}$ of September the said vessel arrived safely in the harbor of Jérémie where the captain began to sell his cargo. A few days after his arrival in the said place the English took possession of the island. The captain nevertheless continued the sale of his cargo and invested the net proceeds of the same in colonial commodities. On the $3^{\mathrm{d}}$ of November following he set sail for Philadelphia; but on the $21^{\text {st }}$ of the same month, being then in latitude $35^{\circ} 20^{\prime}$ North and longitude $74^{\circ} 50^{\prime}$ London (Greenwich) meridian, he met a gale which obliged him to cut down his main mast. In this plight, and being besides short of supplies, he shaped his course for the Windward Islands. When in sight of Guadeloupe, where he was going to repair his vessel, \&c., he was captured by a French privateer who took him to 
the harbour of Basseterre, where the said brig Kitty with her cargo was, contrary to the laws of neutrality, declared a lawful prize.

"Enclosed in the present you will find a letter from Captain William Waters, and a sworn statement made here by Captain James Art. These documents will confirm what I have stated in regard to the condemnation.

"There now remains for me to inform you, Citizen Minister, that I am the bearer of a delegation dated September I8, I793, signed by the Civil Commissioner Sonthonax, for two thousand five hundred and fourteen gourdes and one shilling with interest, which my Captain Congdon received in payment for flour \&c., that he sold to the administration of San Domingo. In view of what I have set forth above and elsewhere, I request you to see that justice is done me."

M. Le Blanc, secretary to the French Legation, replied:

"Le Blanc thanks Citizen Girard for his communication. Nothing astonishes him or he would be greatly surprised at the things now happening. But patience, patience, the time for justice will come!"

Besides his own delegation he had received one from Changeur \& Co. with a request to do what he could to collect. "Our Congress," he replied, "is still quiet, and it is to be hoped that they will wake up and see justice done to their constituents.

"It is said here that Mr. Smith, a member of Congress, was hanged in effigy. When I first heard of this I was very sorry, as I feared it was your representative, but I have been assured that the ceremony referred to took place in Charleston.

"I have had occasion to see citizen Le Blanc, who promised me that Sonthonax's delegation, which you sent me, as well as mine, will be paid and will receive attention 
before any other. You may depend upon it that I shall do all in my power to make this collection for you."

Writing to another, in Baltimore, who had asked concerning some property, he said:

"I enclosed the document, (a receipt) and hope it may be of some use you to, but I fear the English pirates or rather brigands, have not respected this property. These sea robbers recently captured my superb brig as she was leaving Aux Cayes with a full cargo of clayed sugar, coffee and cotton, the whole for my account and that of the Captain. You see that they have no regard whatever for Americans. Recently in the Windward Islands they confiscated more than 60 vessels from our ports as lawful prizes."

M. Genty Lavaud having consigned some goods from Port de Paix, Girard, when acknowledging the letter of information, said:

"You advised me that you had loaded a consignment to me on board the brig Columbia, Captain Rust. You have no doubt heard that the vessel was captured and taken to the Island of Providence, where it is probable that her cargo was declared a lawful prize.

"I am sorry to note that at the time you wrote me your part of the country was not yet pacified. It is to be hoped that order will soon be restored, and when that time arrives we shall be able to undertake operations together that will be profitable to us both.

"Our government has just placed an embargo, or to be more exact, has prohibited for one month, every kind of commerce with foreign countries, and I therefore advise you to procure what provisions you need."

Bentalou having sent coffee and indigo for Girard to sell, he reported the sale and added:

"The abominable conduct of the English towards us 
has forced our Government to pass a decree prohibiting every kind of commerce and intercourse with the said nation. The said decree is to go into effect, on the $I^{\text {st }}$ of next November. If you have any intentions of sending shipments here make your arrangements in advance."

A like warning was sent to Lavaud, who was also told:

"Our government has extended the Embargo until the $25^{\text {th }}$ of next month (May) and it is feared that at that time it will be still further extended." M. Magnan of Saint-Marc, who consigned him coffee, in receiving his account of sale was likewise warned of the non-intercourse act.

Despite the fear that the embargo might be continued, speculations in coffee went on as before.

"The uncertainty in regard to whether the embargo will be continued," he told Changeur \& Co., "has not prevented our speculators from buying and loading coffee for Hamburg and Amsterdam. That commodity is selling at $\mathbf{I} 7$ to $18 d$. per pound with no prospect of a fall.

"As to the embargo, it is uncertain whether it will be continued or not," after May 25th. "In regard to your delegation, the French Minister has given me to understand that he does not believe he is authorized to take it upon himself to pay the obligations incurred with citizens of the United States by the civil commissioners of San Domingo and that he is therefore expecting instructions in regard to that question."

The commercial troubles in which Girard was thus involved through the seizure of his ships and the refusal of the French Minister to receive the San Domingo drafts were the result of the war waged against neutral commerce by France and Great Britain.

The long series of decrees issued by France began with that of February I8th, I793, by which the Republic 
opened the ports in her colonial possessions to American ships and was followed, in March, by another which provided, that from and after the day of its publication in the French Colonies of America, vessels from the United States "of at least sixty tons burthen" should be admitted duty free if they brought only flour, provisions, certain articles named in the arrêt of August 30, 1784, bacon, butter, salted salmon and candles. Any Captain of a vessel from the United States, who, having imported into the French Colonies of America any of these articles, wished to return to the United States might load in the Colonies, besides rum, taffia and merchandise from France, coffee not exceeding one fiftieth the tonnage of his ship, and sugar not exceeding one tenth. But to get sugar or coffee he must prove that two-thirds of his inward cargo consisted of the enumerated articles. The export duties were to be five livres on each quintal of indigo, ten livres on each thousandweight of cotton; five livres per thousandweight of coffee, the same per thousandweight of lump sugar, and fifty sous per thousandweight of raw sugar.

So matters stood on the 9th of May when, by another decree, French ships of war and privateers were authorized "to seize and carry into the ports of the Republic, merchant vessels which are wholly or in part loaded with provisions, being neutral property, bound to an enemy's port, or having on board merchandise belonging to an enemy." Goods, the property of an enemy were to be lawful prize. Provisions, the property of a neutral, were to be "paid for at the price they could have sold for at the port where they were found." This put under ban a larger part of our trade, and violated the 23 rd article of the treaty of 1778 . The purpose of the decree, Morris writes, "was to effect the confiscation of a large cargo 
belonging to a citizen of the State of South Carolina," which had been brought into Le Havre and released by the Court. "The captors then declared that they would obtain a decree for the confiscation, by means of their friends in the Convention, and, sometime afterwards, that of the 9th of May appeared."

Against this Gouverneur Morris protested vigorously, as violating the $23 \mathrm{rd}$ article of the treary of 1778 , which declared that free ships made free goods, and on May $23 \mathrm{rd}$, by another decree, ships of the Unites States were expressly exempted from the provisions of that of May ninth. It was on the 26th of May that Le Brun announced this fact to Morris; nevertheless two days later the decree of the 23 rd was repealed. "The interested parties as soon as this dercee was passed," Morris wrote, "went to work (as I was afterwards informed) and by force of money, my informant says, procured the decree of the 28th."

Again Morris protested and on July first the Convention once more decreed "that the vessels of the United States are not comprised in the provisions of the decree of the ninth of May, conformibly to the twenty-third article of the treaty made the sixth of February, 1778." This too, proved worthless and in its turn was repealed before the month ended.

Great Britain, meantime, struck back and on June 8th, I793, issued an Order in Council entitled, "Additional instructions to His Majesty's ships of war and privateers." By it they were bidden to stop "all vessels loaded wholly or in part with corn, flour, or meal bound to any port in France, or any port occupied by the armies of France," and send them to the most convenient port for examination. There the flour, corn and meal were to be bought by His Majesty's Government and the 
ships released. If, however, a court of admiralty approved and the Captain gave due security, the vessels might "proceed to dispose of their cargoes of corn, meal or flour, in the ports of any country in amity with his Majesty."

Commanders of ships of war and privateers were further ordered to seize all ships whatever their cargoes, found attempting to enter a blockaded port and send in the ships and cargoes for condemnation. Vessels of Denmark and Sweden should "only be prevented from entering on the first attempt;" and not sent in till the second.

Though issued in June it was September when Jefferson received a copy through a channel which could not "be considered as authentic." Well aware, however, that the copy was a true one, he wrote at once to the British Minister and protested. The article regarding the seizure of flour, corn and meal was contrary to the law of nations. When two powers, he wrote, "go to war, those who choose to live in peace retain their neutral right to pursue their agriculture, manufactures and other ordinary vocations; to carry the produce of their industry, for exchange, to all nations, belligerent or neutral, as usual; to go and come freely, without injury or molestation. If any nation whatever has a right to shut up, to our produce, all ports of the earth, except her own, and those of her friends, she may shut up these also, and so confine us within our own limits. No nation can subscribe to such pretentions, no nation can agree, at the mere will or interest of another, to have its peaceable industry suspended and its citizens reduced to idleness and want. The loss of our produce destined for foreign markets, or that loss which would result from an arbitrary restraint of our markets is a tax too serious for us to acquiesce in. It is not enough for a nation to say, we and our friends will buy your produce. 
We have a right to answer, that it suits us better to sell to their enemies as well as their friends."

"This act too, tends directly to draw us from that state of peace in which we are wishing to remain. It is an essential character of neutrality to furnish no aids (not stipulated by treaty) to one party, which we are not equally ready to furnish to the other. If we permit corn to be sent to Great Britain and her friends, we are equally bound to permit it to France. To restrain it would be a partiality which might lead to war with France. In the case where we found ourselves obliged, by treaty, to withhold from the enemies of France the right of arming in our ports, we thought ourselves in justice bound to withhold the same right from France also, and we did it. Were we to withhold from her supplies of provisions, we should, in like manner, be bound to withhold them from her enemies. This is a dilemma which Great Britain has no right to force upon us. $* * * *$ She may, indeed, feel the desire of starving an enemy nation; but she can have no right of doing it at our loss nor of making us an instrument of it."

On the instruction to British commanders to seize, for condemnation all vessels on their first attempt to enter blockaded ports, save those of Sweden and Denmark, Jefferson observed, "Of all the nations inhabiting the shores of the Atlantic Ocean Denmark, Sweden and the United States, alone are neutral. To declare, then, all neutral vessels $* *$ to be legal prize, which shall attempt to enter a blockaded port, except those of Denmark and Sweden, is exactly to declare that the vessels of the United States, shall be lawful prize and those of Denmark and Sweden shall not."

Mr. Hammond replied that by the law of nations all provisions were contraband whenever "the depriving of 
our enemy of these supplies is one of the means intended to be employed for reducing him to reasonable terms of peace" and that with respect to the rule regarding blockaded ports "the exception there mentioned as to Denmark and Sweden has reference to existing treaties with those powers."

The flight to the United States of the French fleet from San Domingo, laden with refugees, and the preparations of Great Britain to attack the French West India Islands, brought forth a new British Order in Council, that of November 6, 1793, which placed under ban our trade with the French colonies. Commanders of ships of war and privateers, so ran the order, "Shall stop and detain all ships laden with goods and produce of any colony belonging to France or carrying provisions or other supplies for the use of any such colony, and shall bring the same, with their cargoes, to legal adjudication in our courts of admiralty."

Late in December the Order was made public at the admiralty and by another dated January 8, I794, was revoked. Commanders of ships of war and privateers were then instructed to "bring in for lawful adjudication all vessels with their cargoes that are laden with goods the produce of the French West India Islands and coming directly from any port of the said islands to any port in Europe" or, "laden with goods the produce of the said islands, the property of which goods shall belong to subjects of France, to whatever port the same may be bound."

Meantime the Order of November 6th had been rigorously enforced, and in a few weeks hundreds of thousands of dollars worth of American ships and cargoes were in British hands. Alarmed at their losses the merchants and ship owners of Philadelphia met in January, put Girard in the chair, adopted strong resolutions and ap- 
pointed a committee to draft a memorial to Congress. This set forth that it had become the practice of privateers of powers at war "to send into port all American vessels they met with, bound from any of the French ports in the West Indies to the United States; and it is positively asserted, that the owners of some of them have given general instructions to their captains to that effect; and, though many of those vessels have been afterwards liberated, yet the loss by plunder, detention, and expense, is so great, as to render it serious to the American owner. In many cases, where the cargoes have been valuable, the owners of the privateers, after acquittal, have lodged appeals which they never intended to prosecute, but merely with a view of getting the property into their hands upon an unfair valuation." Besides the loss thus inflicted "masters and crews of vessels are frequently subjected to insult and outrages that must be shocking to Americans." Already commerce was beginning to languish and the crops of the farmers were "likely to be left upon the hands of those who raised them." The irruption of the Algerines from the Mediterranean in consequence of the truce concluded with that regency, "it is said, by the British minister, in behalf of Portugal and Holland" was an alarming event. "The immediate rise it has produced in insurance, and the fear it may instil into our seamen and commanders" were matters deserving the serious consideration of Congress.

The merchants and traders met on the 8th of March at The Harp and Crown, a tavern kept by Barnabas McShane on 3 rd Street below Arch, to receive the report of the committee but adjourned to meet again at the same place three days later. Girard was then put in the chair and three resolutions adopted. One set forth that the carrying trade of the United States and the defense of 
its harbors were of primary importance: another, that "citizens of the United States owners of ships and cargoes and sailing under the sea letters of the President and proper clearances of the Custom House have a right to be reimbursed for losses sustained from vexatious spoliations committed by any power whatever;" a third, that "additional imposts on the vessels, goods, wares and merchandise of any nation so offending, imported into the United States," would make a proper fund to reimburse such losses. Before adjourning to the 18 th, it was resolved, "that the thanks of this meeting be presented to the Chairman, not only for his perfect services, but for and in grateful remembrance of his dangerous and meritorious services rendered to the city on a late melancholy occasion."

The meeting on the 18 th was held in the State House Yard with Girard again in the Chair and a long report presented. In this it was charged Great Britain had "arbitrarily refused" to surrender the western posts; "clandestinely fomented and maintained" a savage war on the frontier: "insidiously let loose the barbarians of Africa" to plunder and enslave our citizens: "arrogantly attempted to set bounds" to American commerce; "violently seized and sequestered" American vessels worth several millions of dollars; "insultingly imprisoned and forcibly impressed" into her service several thousand American citizens; and "contemptously ignored all complaints." Sufferings of American citizens, it was resolved, called loudly for redress, and measures ought to be adopted by the government to prevent more property falling into the hands of the Algerines or of Great Britain.

Girard was in favor of relief as well as redress. $\mathrm{He}$ felt strongly for the prisoners in the hands of the Algerines and moved, says a report of the meeting, "that Vol. I-16 241 
a committee of five citizens be appointed to prepare a plan for soliciting donations from all benevolent and patriotic freemen for the purpose of establishing a fund to relieve and redeem our unfortunate fellow citizens who, sailing on board of vessels belonging to the port of Philadelphia, have been captured and enslaved by the Algerine or any other piratical state." This was adopted and Swanwick, Israel, Jacob Morgan, Alexander J. Dallas and Girard were appointed a committee to report a plan to a meeting on the 22nd of March. They recommended that five citizens in each ward and the commissioners of the several counties be a committee to solicit money, and that a Board of thirteen Trustees be formed to supervise the collection, management and disbursement of the fund. This was approved and Girard was made a trustee.

While these merchant meetings of protest were under way he was made yet more conspicuous by another series of gatherings of citizens held in grateful recognition of those who served the city so well in the dreadful months of the yellow fever. The Health Committee appointed on September 14th, I793, had as yet made no report of its work. That such a report might be properly made the Mayor called a meeting of the citizens of the City of Philadelphia, the District of Southwark and the Township of Northern Liberties, at the City Hall on the 8th of March. After describing its work in detail the committee reported that the Bank of North America had advanced $\$ 6500$, that public donations amounted to $\$ 29$,089 and the deficit to $\$ 3545$. It was then moved that a committee be appointed to prepare an instrument "expressive of the cordial, grateful and fraternal thanks of the citizens." This was carried and Saturday March I 5 th was chosen for a second meeting at City Hall to hear the report. 
The document is too long to cite in full, but the first resolution read: "Whereas the following citizens of Philadelphia (naming twenty-one with Girard second in the list) totally disregarding their own personal preservation and only intent on arresting the progress of the malignant disorder with a magnanimity and patriotism worthy the highest eulogium, stood forth and by every generous and endearing exertion preserved the lives of many of their fellow citizens from death by conveying them to a suitable hospital which they too prepared at Bush Hill for their reception where under the meritorious and peculiar care of Stephen Girard and Peter Helm" every possible comfort was provided, therefore

"The citizens of the City of Philadelphia, the District of Southwark and the Northern Liberties" do by this instrument present to (naming seventeen of the twenty-one; four had died of the fever) "most cordial, grateful and fraternal thanks for their benevolent and patriotic exertions." It was further resolved that a copy of the resolutions so passed and signed by the Chairman be presented to each of the seventeen living and the families of the four dead members of the Health Committee. It was further resolved that $\$ 3245.12$ be paid to the committee to discharge the deficit; that $\$ 2654$ be put in the hands of the Committee "for the use of such persons who either on account of their own services or the services of deceased relatives during the late public calamity shall be willing to accept a compensation of that nature," and that $\$ 2800$ be expended in the purchase of twenty-eight pieces of plate at $\$ 100$ each to be presented to the twentyone active members of the Committee or their families, the Guardians of the Poor and the Assistant Committees of Southwark and Northern Liberties.

Another meeting was then called for March 2oth; but 243 
so few attended that the Committee of seven announced it "could not think" itself warranted in proceeding further upon this important occasion without the express approval of its fellow citizens "and requested" a general meeting at the City Hall on March 22nd. Then and there the plan was adopted, a committee of thirteen, of which Girard was one, was appointed to act as trustee and name Ward committees to collect the needed money. He was thenceforth a citizen of prominence.

From our consul at St. Eustatius came a list of one hundred and thirty ships condemned by the Vice Admiralty Court. From Bermuda came a list of eleven more, and a description of the treatment of Captains, crews and passengers. No sooner, it was said, did the anchor touch bottom in the harbor of St. George's, than a boat would put off from shore, and men clamber up the sides of the ship, and begin their infamous work. Trunks and chests would be brought on deck, broken open and pillaged; beds would be cut open and searched for money, papers, trinkets and gems; packages and letters would be carefully examined, passengers summoned on deck, questioned closely, searched and after all their clothing was taken save what they had on their backs, sent ashore. The sailors would then be abused, insulted and sometimes pressed into service on a privateer, and the ship hauled to the wharf, her sails unbent and the cargo run out.

As many as thirty-five sail were at one time libelled at Basseterre. When the captains applied to the judge to know why they were detained he sent them to the captors, and when they applied to the owners of the privateers they were sent back to the judge.

Forty captains signed an account of what happened 244 
at Martinique. In February a fleet and army entered the harbor of St. Pierre. While the ships bombarded the town the troops landed and took it. Every American schooner and brig in port was then boarded by marines, the colors torn down, the sails unbent, and the sailors sent to the deck of a man-of-war, examined, and finally confined in the hold of a prison ship. When they came forth three days later, their tongues were swollen with thirst and their bodies wasted by hunger. Of the brigs and schooners they once had manned some had broken from their moorings and drifted to sea, some had gone ashore and bilged, and others had been anchored so close that they had chaffed through and sunk. Letters from ship captains, at St. Kitts and Montserrat, told of a state of affairs quite as bad.

Fulwar Skipwith, American Consul, wrote from St. Eustatius, in March, that early in February the ship in which he had taken passage for Philadelphia was captured by the Experiment, privateer of Bermuda, carried into Montserrat; stripped of her sails; " and, by order of the judge the Captain's papers and mine were peremptorily demanded. I waived a compliance and at the instant waited on the judge and, in the mildest terms, observed the impropriety of my exposing by compulsion public papers which, if the United States were not at war with England ought to be deemed sacred; or my private papers which did not, in the most indirect manner, relate to the ship or cargo in question. Such assurances did not satisfy the curiosity of the judge; and, the next day my desk was seized and forced." Two hundred and fifty ships, he said, had been captured, brought into the British Windward ports and libelled, and of these one hundred and fifty had been condemned. "The greater part of the people belonging to these vessels have rendezvoused 


\section{THE LIFE AND TIMES OF STEPHEN GIRARD}

here (St. Eustatius) in order to obtain passage for America and, having been stripped, many of them of the little resources they had possessed, I have ventured to procure, on account of the United States, a sufficiency of bread, beef, water, to support them to their respective homes."

Complaints of all these depredations, which for months past had been coming to the office of the Secretary of State, were reduced to order by Randolph and, in March, 1794, were by Washington laid before Congress.

Randolph, in his report to Washington, cited the Philadelphia memorial, as truly setting forth "the embarrassments, danger, and even ruin which threatens our trade." From documents in his office it appeared that British privateers plundered American vessels, threw them out of their courses by forcing them into ports other than those for which they were destined, exposed the cargoes to damage, the vessels to destruction, and ill-used the crews; that British ships of war seized American sailors; that by orders in council our corn and provisions were driven from ports of France and restricted to ports of Great Britain; that our vessels were not permitted to go from the British ports in the West Indies without giving security to discharge the cargo in some other British or neutral port; that our vessels were captured for trading with the French West Indies; and that the conduct of the admiralty in the British West Indies was marked by excessive rigor, and a departure from strict judicial purity.

The French also were not guiltless. Their privateers harassed our trade; two of their ships of war had committed enormities on our vessels; their admiralty courts were guilty of oppression; they had infringed our treaty by subjecting to capture and condemnation our vessels 
trading with the enemies of France in merchandise not contraband by the treaty or the law of nations; and they had laid a ruinous embargo on American vessels in French ports.

Congress needed no such information. Not a member from the seaboard but could call over a list of names of merchants whose ships had gone out laden with produce and not yet come back. Others had read in the newspapers long letters from Dominique, Antigua, Montserrat, St. Kitts, describing the depredations committed on our commerce, and the stirring language in which the conduct of Great Britain was denounced in every seaport in the land. The traders of Charleston passed strong resolutions, as did those of Portsmouth, Boston and New York. At Marblehead three thousand men began to drill. At Gloucester two hundred seamen whose ships rode at anchor in the bay marched to the old fort, raised a flag and swore they would defend it against British insolence to the last. Salem presented a doleful sight. Gloom, it was said, sat on every face. Trade and commerce were dead, merchants ceased to buy and sell, sailors strolled in idleness through the streets and laborers were starving in idleness.

Congress by this time had begun to put the country in a state of defence. One hundred and thirty-six thousand dollars were voted for building forts along the coast from Portland to St. Mary's. The sum was small but the enthusiasm of the people made it enough, for, at the seaports men of every profession, trade and occupation came forward and without pay labored on the forts. At New London the ship-captains and the townfolks worked for two days on Fort Trumbull. At New York Baron Steuben examined every part of the fine harbor and chose two hills which command the Narrows. 
But Governor's Island was selected and there from April till June the citizens of New York and Brooklyn toiled without hire. The Democratic Society went down in a body one April day, the Tammany Society on another, and were followed in turn by the Coopers, the Patriotic Bakers, the Patriotic Sawyers, the Patriotic Sail Workers, the School Masters, the lawyers and the students of Columbia College.

Having provided for the defence of the coast Congress in March laid an embargo and shut the ports to foreign trade and commerce for thirty days and when that period expired continued it for thirty more. Everywhere the people insisted on a strict observance of it, and when it was lifted late in May denounced the Government heartily. At Philadelphia the captains of the brigs and sloops met at the Harp and Crown Tavern, pledged themselves not to go to sea for ten days and agreed that if any one of them were discharged because of this determination none would fill his place.

In January, Madison had introduced into the House of Representatives a long set of resolutions intended to affect Great Britain. They provided for an increase of tonnage duties on vessels of nations with which the United States had no treaty of commerce. Great Britain was such a country. They provided for a lowering of tonnage duties on ships of nations with whom we had commercial treaties. France was one of them. If any European power refused to consider as American vessels owned, but not built, in the United States, a like treatment should be accorded the ships of that power built in ports not her own. If a nation shut out articles made or grown in the United States because they did not come in our ships, or refused them a landing because they were carried in our vessels, the restrictions were to be made reciprocal. 
The first of Madison's resolutions passed the House; the others never came to a vote. They seemed too mild, and the day the embargo act was passed Jonathan Dayton of New Jersey moved another set. He proposed to sequester all debts due from citizens of the United States to subjects of King George, and hold the money in the Treasury as a pledge for the indemnification of such merchants and captains as had been robbed of ships and cargoes by British ships of war and privateers. These also failed of adoption and another set was moved by Mr. Clarke.

In the form of a non-intercourse bill these provided that after November first, 1794, "all commercial intercourse between the citizens of the United States and the subjects of the King of Great Britain should cease." The bill passed the House but was lost in the Senate by the casting vote of Vice-President Adams.

Alarmed at the action of Congress, and bent on preserving peace, Washington now sent to the Senate the name of Chief Justice John Jay to be minister from the United States to Great Britain. The nomination was confirmed and in May Jay sailed from New York and in June landed at Falmouth.

On May 25th the embargo, which for two months past had closed the ports to foreign trade, was lifted, greatly to the disgust of the people. Last night, said a writer in a New York newspaper, there departed this life General Embargo. The funeral will be conducted with naval honors. A vast fleet of merchantmen will sail from the ports of America and rendezvous in the British West India Islands. In the fleet which did sail Girard had no vessel, for during the embargo not one of his ships entered port. All were in the hands of the belligerents. 


\section{THE LIFE AND TIMES OF STEPHEN GIRARD}

La Virginie had been sold at Marseilles; the Good Friends was embargoed at Bordeaux; the Kitty had been sent a prize to Basseterre; the Polly was a prize at Bermuda, and the Sally at Jamaica.

The Sally of which he was half owner with Captain Cochran had gone to Aux Cayes. From that port the Captain on February I2, I794 wrote he was happy to say that the French Administration had paid for the cargo, in coffee, cocoa, sugar and cotton, a sum amounting to 95,2 ro livres; that he had been forced to sell to the government, from his last cargo, flour and pork to the value of 18,150 livres; that the cost of the produce he would bring back was I 17,210 livres, (in paper money) and that he would sail in two or three days. It was the middle of March when Girard received the letter and no more was heard of the Sally till the middle of April when another letter, dated Kingston, Jamaica March 4 came to hand. "I am sorry to inform you," Cochran wrote, "that I sailed from the Aux Cayes February 25th with the net proceeds of both cargoes in sugar, coffee, cotton, cocoa and Bar Iron amounting to $£_{5} 645,15,6$ pensalvaney currency, with charges, and the saime day I sailed from the Aux Cayes, was taken by the schooner Hauck privateer, and the friggate Sucksess Captain Robbarts, and sent down to this port without ever looking at anney of my papers notwithstanding the ware convinced that theire ware neither French property nor passangers on Board. But the said theire Orders ware to send all Nutrul Vessels into a Britash port Either Bound in or out a French port the privatur Hauck that firs Boarded me Belongs to $\mathrm{Mr}$. Kingston, merchant of this place home is agent for the frigat and the privatur and I have Been Examined and Sworn to the Vessel and Property with the mate, and one of my peopal which the find all 
to agree and theire convinced that the Brig and Cargoe is the Property of you and me and that no other has anney part theirein." He fully expected that both brig and cargo would be libelled, as in all probability would thirty other American vessels in the port.

The next letter from Cochran dated March 2oth gives the value of the cargo as " $£ 6 r 24,1,10$ pensyalvania Currency" but he could not say "how long this piratical Villain Wm. Kingston will let it remain on Board." "I have been examined with respect to Evoreything respecting the Brig since I first new her and since I first new you and whaire we ware Born and how we have spent the last seven years of our time, and sworn to them and a hundred more such questions, and my mate and one of the people, and the found all to the same purport. But notwithstanding all this the have Libiled my Brig and Cargoe as. french property althou theire is not one pound of goods on Board the Sally belonging to anney Person alive but you and my-Selfe and the pirate would wish to make a frenchmen of me for the Sake of the property on board the Sally."

While Cochran with the Sally was held prisoner at Kingston, Congdon was writing from St. George's, Bermuda, to announce the second capture of the Polly.

After her release in September 1793 she returned to Philadelphia and in December was dispatched to Pointe a Pitre in the island of Guadeloupe. There Captain Congdon was to sell the cargo to the best advantage for cash, or barter it for good green coffee, and return to Philadelphia. Any money remaining after the Polly was entirely loaded was to be expended in the purchase of cotton, to be carried on the deck, provided that article could be had at moderate price. Should the market at Pointe a Pitre be poor, or, for any reason, the vessel and 
cargo seem unsafe, Captain Congdon might go to another port in the island.

After the departure of the Polly nothing was heard from her until Captain Congdon wrote from Basseterre. "I have waited here all winter for a market as I know not whear to better myself and about Io days ago flour and pork took a rise and I had a prospect of selling the remainder of my cargo to a good advantage but onfortunatly the public demanded all the provisions in the place, but we all refused to deliver to thear orders but at last thar came on board of us the interpretter, one of the minissepallity, and several officers with a number of men and began to discharge my cargo which remained on board they have taken four hundred bbls. flower, 120 bbls. pork, 5 large cases and 2 small ones of sweet oil. the fleet has just now gon from a long side with the last of it. They tell us that they will pay us in shogar or bills on france. but we nose not what they mean to allow us for our provisions. I have noted a pertest against thear proceadings tho I should take the shogar if thear is a prospect of getin it, thear has been an Embargo on all vessels ever since martineco has been beshed to this time and know thear is only certain vessels a loud to go. all the people at this place is under arms and they loock dayly for the british to come. thear a pears to be much oneasyness at point peter a mong the inhabitants several of them have fled to this place. the publick seeses all provisions at the point as well as hear."

April ist he was still at Basseterre but had been paid 50,000 livres in sugar and was promised the remaining 7000 in "the first shogar or coffee they get." Payment was finally obtained and he sailed on April Ioth "which was as soon as I could get payment for the provisions that the Public toock from me, and on the Igth I was 
taken by the schooner Enterprize Capt. Joseph Robinson, she belonging to Messrs. Robert tucker and jenins merchants of thes place. we arrived here 7 th of May and was libeled I6th and I expect our trial will come on tomorrow, but no prospect of being cleared as all the vessels that has ben tryd hear sence we was brought in has ben condemned that had french produce on or had ben to a french port all tho thear is surficient proof of thear vessels and cargo being american property. ${ }^{*} *$

"My papers was all taken from me as soon as I ariv'd hear and every boock and scrap of paper that had any writing on, thear is every article set down in my boock that was sold and how much sold for, and the quantity and price of every thing that I ship'd on board, *** thy also toock from me all the money that was on board wich was I600 dollars of yours which is mentioned on the bills of laden and 440 dollars of my own money and at the same time give me roo dollars out of that to make use of, and sence they have given me 20 dollars more."

This news coming almost at the same time as the letter from Captain Cochran telling of the capture of the Sally was a heavy blow to Girard; but he lost no time.in seeking to recover his ships. To prove American citizenship he wrote to Mr. John Ferrers of New York:

"Having two brigs taken, one from Aux Cayes carried to Kingston Jamaica, and the other from Basseterre Guadeloupe, carried to Bermuda, and wishing to prove my citizenship as far back as possible, I request as a particular favor that you will solicit my worthy friend Captain Thomas Randall to give you a certificate in four copies properly attested before a notary public and certified by the English Consul of your state, that he knew me since July I774 at which time I was mate on board the Snow baptain bound to New 
Orleans, since which time I have been sailing out of New York until May 1776 when I arrived at Philadelphia master of a ship owned by him and me." The snow, he states, was L'Aimable Louise and the name of the Captain, Malahard; but as she was renamed at New York and a new captain employed he wished the English names inserted in the certificate.

Mr. John Vaughan was requested to give him a letter to Messrs. Bridgman \& Hall, in Kingston, requesting them to enter security for the Sally and her cargo and advance Captain Cochran such funds as he might require, and similar letters were written to Messrs. Elliston \& John Perot and Cramond \& Co. Everybody applied to complied at once. From Thomas Randall at New York came a certificate drawn up as Girard requested, and attested by Phineas Bond, Consul General of Great Britain, setting forth "That he was acquainted with Stephen Girard, now of the city of Philadelphia, in the State of Pennsylvania, merchant, in the year of our Lord one thousand seven hundred and seventy four, at which time he sailed as mate of a Snow or Vessel from New York to New Orleans, and that he continued to sail out of said port till the month of May in the year of our Lord one thousand seven hundred and seventy-six when he arrived in Philadelphia commander of a Sloop of which the deponent and the said Stephen Girard were joint owners since which period the said Stephen Girard has resided in the state of Pennsylvania."

Isaac Hazlehurst certified that he had known him since 1776 and had sold him a piece of property in 1777 ; that he had ever since carried on an extensive business as a resident merchant in Philadelphia, was a citizen of the United States and a "considerable owner of Real Estate, a house keeper, and married man of character, 
credit and repute in said city." Phineas Bond, his Britannic Majesty's Consul General for the Middle and Southern States of America, certified that Clement Biddle who took the affidavit of Mr. Hazlehurst, was a notary public duly commissioned by the Commonwealth of Pennsylvania. Copies of these and sundry other documents were then sent to Messrs. Shaw \& Inglis and to Messrs. Bridgman \& Hall, asking them to go security for the ship and cargo, and to Captain Cochran giving him instructions how to proceed in his attempt to recover the Sally. A like set of papers was also sent to Captain Congdon at St. Georges. Mr. John Gardener, Jr., was charged with the delivery of the papers, was instructed to "apply to the best attorney," was given a power of attorney to act for Girard, and dispatched by the first vessel.

Edmond Randolph, Secretary of State, was next appealed to in behalf of the Kitty. "Inclosed," Girard wrote, "is the Protest of William Waters master of my Brig Kitty lately condemned at Basseterre, Guadeloupe by the Governor Collot and roisin Intendant of that Island. The unjust motive given by the said Governor and Intendant for the unlawful condemnation of said vessel and cargo, together with the inhuman treatment which Captain Waters and his people have experienced by imprisonment and then being plundered in the same manner as if they had been taken by the Algerines, claim your particular attention."

Five months had now passed without any news from the Good Friends, nor did any come till November, when Girard received from his brother a letter, July 1793.

"We arrived in the River of Bordeaux on the 13 th of July at noon, and in front of the town to-day. We were boarded in Longitude I4 degrees, London, and 45.53 degrees latitude north, by a Liverpool privateer, the 
Thomas, Captain Huson, who found everything in good order, and wished us a prosperous voyage. We met another very small one in fifty-five fathoms of water which, after crossing our bows and gaining the wind bore down on us. As the decks and the down haul of the studding sails were crowded and we did not show him our colors, he decided to leave us. This vessel of ours, the Good Friends, could not be a better sea boat, but she careens enough to make one tremble. I wish you would let me cut down her masts, for I shall do nothing without orders from you. It would be too bad, not to say a real misfortune, to upset or not be able to get her afloat after driving on a lea shore. These things disturb me every time I think of them.

"To come back to business. In the first place I do not wish to say anything about our unfortunate country. It is in a deplorable condition and there is no use saying anything more, for matters are even worse than I told you when I reached Le Cap, and what I then surmised as to royalty is now the general talk.

"I am busy with your interests. Fearing to receive contrary orders by the Kitty, which I am waiting for, I did not at once proceed to take on freight for the islands at 350 livres per ton and I05 livres master's gratuity, payable in specie and in gourdes at 8 livres, 5 sous. There are a number of Americans who have come here from London, Amsterdam, Dunkirk, Le Havre and Nantes to take on cargoes of this kind.

"Tobacco is worth 220 to 230 livres; cotton 800 livres, but it is impossible to buy a crown of 6 livres for 20 livres in paper money. Wines from 1200 to 6000 livres per ton; brandy 550 to 600 livres for 32 veltes."

Part of the return cargo for the Windward and Leeward islands was 200 tierces of brandy costing from 600 
livres to 650 livres for 32 veltes. "This price is exorbitant but I do not know how else to invest the 7 to 800,000 livres which represents the proceeds of the entrance cargo of the ship Good Friends, as her outgoing cargo for the islands will not amount to more than 300,000 livres not including the cash which I shall add to the balance of your funds; as your object is to realize well in America. To leave paper money here would be to imitate American fanatics like Rush and others who will be sure to be cheated in the end.

"I am not at all satisfied with F. E. (Francis H. Ellison, Captain of the Good Friends) who from sheer obstinacy anchored in the third row so as to discourage one from going ashore. In that way he has forced me to take a room on shore where I am incurring an expense I cannot afford, which does not at all agree with my ideas of economy. I forsee I shall incur a great deal of expense in the Islands, and shall have to suffer a great deal from the evil disposition of this vain and haughty man who is vexed because he has not the management of the ships cargo, and has already insulted me grossly. I will say nothing about his laziness: but I promise you to bear all my troubles patiently and without complaining."

Enclosed in this letter was one from Samatan to Jean Girard telling him that La Virginie had been sold for 90,$\infty$ livres, asking for news of the ships La Félicité and Joseph, and returning two remittances drawn on the Treasurer of the Navy for 666 livres, I 3 sous, 4 deniers, and 1333 livres, 6 sous, 8 deniers. He had sent them to $M$. Gorrant who replied that these claims had been repudiated and no longer formed part of the public debt, and then cancelled instead of recording them.

More complaints against the Captain followed. August third he wrote, "there is a project on foot to seize and

Vol. I-17 
send away empty all neutral vessels that have come here with false freight or in ballast. I have no fear from that source; but I do fear future events." He had therefore stopped buying the outward cargo. "Added to all this I have the greatest fop, coward and sluggard for a captain that you could possibly have found. He would like to load nothing but freight so as to get his master's gratuity. But your interests demand the contrary for freight has gone down to 200 livres per ton no matter what is loaded. This animal who lies in bed till half past seven and eight o'clock, spends his time decking himself out and coming to insult me."

By September ist Jean Girard was able to report that the sale of the inward cargo amounted to 515,475 livres, 3 sous, and the cost of the outward cargo 379,082 livres. November IOth, I793, this letter reached Girard, but not a word more came from the supercargo, nor was anything heard of the Good Friends till the middle of February, I794.

Now he hears that a vessel which left Bordeaux early in September has reached Norfolk and brought news that the Good Friends had been unloaded and asks Messrs. Changeur \& Co., if they will please find out if this be so and inform him. Early in January writing to Messrs. Bonnaffé frères et fils at Bordeaux he said: "We are at the present moment in the heart of our winter and the sloop Good Friends has not yet put in an appearance. The last news I have from you is dated the I6th of July and that from my brother Jean Girard, September Ist, last.

"The war now being carried on by the European pirates is very disturbing to our commerce. We are neutral only in name, for our ships are not only stopped and plundered daily, but even run the risk of being taken to the ports of these despots who while observing legal 
forms, rob us of our cargoes." Writing that same day, January 6th, to Samatan, Girard reports that "My brother informs me that you have sold my brig La Virginie for 90,000 livres tournois and after paying Messrs. Bovay \& Co. what I owed them, you will remit to my brother in Bordeaux in soap, Gruyere cheese, \&c.

"The peace which the Portugese have made with the Algerines makes me very uneasy as to the fate of my ship, which has not yet put in an appearance. If, by any chance, you hear that the vessel has been captured by these pirates, and taken to some port in Barbary, please hasten to do everything necessary to liberate my brother who is a passenger on board. As for the expense you incur I will account to you for the same in any way most convenient for you.

"It is now the 7th of January and our Congress is in session. It seems that the public in general is not satisfied with the conduct of European nations towards us, and it is quite possible this may induce us to take part in the war."

At last, late in February, a letter came from Jean Girard, dated December $22^{\text {d }}$ I793, reporting that the ship had been held and was still held by an embargo laid on the port of Bordeaux; that he had been forced to unload part of the cargo, and feared the confiscation of the rest, and contained a copy of a protest made before Joseph Fenwick, United States Consul at Bordeaux.

From the protest it appeared that while the inward cargo was unloading Jean Girard, in order to hasten his departure, had begun to buy the outward cargo; that he had started "to load said ship on the $29^{\text {th }}$ of July last, having at that epoch made all his purchases; that he had continued to load said ship, but that the decree of the $15^{\text {th }}$ August last, prohibiting the exportation of sundry articles 


\section{THE LIFE AND TIMES OF STEPHEN GIRARD}

of his cargo, in return, had forced him to suspend said shipping until the decrees of the $3^{\mathrm{d}}$ and $\mathbf{I}^{\text {th }}$ September following, which permitted the exportation to only the vessels which had imported, as this one had, articles of first necessity, upon which he, Jean Girard, had continued and effectuated the loading of the said ship Good Friends, the $5^{\text {th }}$ September last."

He had then tried to clear the ship, but seeing his countrymen stopped below the river, thought it best to wait and while so doing the embargo laid on the port had ever since detained him to the great injury of the ship and cargo and cost to the owner. Against all this he protested and in the name of his brother claimed damages. He also protested against the injustice of keeping the Good Friends in port when the ship Richmond and the brigantine $N y m p h$ with cargoes of the same sort as his were allowed to go out the week before, and protested against being forced to unload his ship as contrary to all treaties of Amity and Commerce between the United States and France.

On receipt of the letter, Girard wrote to Alexander Hamilton, Secretary of the Treasury, stated the case briefly and asked that such steps be taken as "justice and the interests of a citizen of the United States may require."

"I am to acknowledge," wrote Hamilton in reply, "the receipt of your letter of the $26^{\text {th }}$ instant, a copy whereof I have immediately sent to the Secretary of State to whom all such applications are to be made, and who I doubt not will pay due attention to your expectation."

A letter from Jean, written in English on January $5^{\text {th }}$ 1794, reported the sales of the inward cargo amounted to 503,834 francs, and the cost of the outward 467,996 260 
francs; that after having it on board he was forced to land it; and that he was about to set off for Paris in hopes of negotiating the drafts on the National Treasury.

About the middle of March the letter reached Girard, but as months passed and nothing more was heard of the Good Friends Girard, on June fourth, wrote Bonnaffé frères et fils.

"My last letter received from my brother Jean Girard is dated the $5^{\text {th }}$ of last January. At that time he told me the ship Good Friends was being unloaded and that all American vessels then on the River at Bordeaux were in the same predicament. If the French had known my intentions they surely would not have upset my operations in so ruinous a manner.

"I had intended to continue the ship Good Friends in the Bordeaux trade and perhaps even to add one or two ships according to circumstances; but the results of my first adventure force me to be prudent. * * *

"Meantime let us talk about the drafts on the French Treasury which I sent you by my ship Good Friends, and the certificates for which I asked you to prove that the coffee which I consigned to you by the ship Betsy was unloaded at Bordeaux. It is very important that $I$ should have the latter document to enable me to annul the exportation bond that $\mathrm{I}$ was forced to furnish in this city and to obtain the return of the duties which is quite a considerable sum.

"In addition to the drafts that you secured for my account by the Good Friends, I sent you enclosed in my letter of the $27^{\text {th }}$ of July last, in duplicate, five drafts of the administration of San Domingo on the National Treasury. They were all certified by the consul of the French Republic in Philadelphia. As I have never heard anything about these drafts I send you enclosed five 
copies of them, in order that you may obtain payment if you have not already collected them.

"There is a rumour here that the Citizen Samatan, formerly a merchant of Marseilles, has been condemned to death and his property confiscated for the benefit of the French Republic. As I had very large business dealings with the said firm there is a balance in my favor both on the Philadelphia and on the Marseilles account and I accordingly send you my power of attorney to collect the money due either from the government or from those settling the affairs of the firm."

Citizen Le Blanc who was going to France was requested to carry the letter to Bonnaffé frères, and was asked "to take the trouble to do what is necessary in France to obtain leave for the Captain of my ship Good Friends to reload his return cargo which he has been obliged to reland in Bordeaux and sail from that port, if he be still there, for Philadelphia." Since her arrival at Bordeaux he had received his " account of sale of the outgoing cargo amounting to 503,834 livres, 8 sous, 5 deniers tournois, which, added to 56415 livres, I I sous, the amount of certain drafts on the National Treasury sent to Messrs. Bonnaffé frères et fils, given in return for certain supplies my captain was obliged to furnish and deliver to the administration in San Domingo, and about 100,000 livres in which I had at that time deposited with another business man, makes in all the sum of 660,249 livres, 19 sous, 5 deniers tournois which sums are being detained along with the vessel in Bordeaux by the embargo which has existed there for sometime."

"As for the brig Kitty and her cargo, I have furnished you the petition and other documents relating to these two items; and as you are thoroughly familiar with this unfortunate affair, I feel confident that you will without 
difficulty induce the representatives of the French nation to give the necessary orders for the payment in this country of the account which I have given you, amounting to 30,669 gourdes, and fifty one hundredths, with damages and interest.

"In addition to the above mentioned sum I claim, in the name and for the account of the officers and crew of my said brig Kitty, that they be reimbursed in this city for the losses caused by the injustice of the Governor, Intendant \&c. of the Island of Guadeloupe.

"With regard to the delegation dated September I8, 1793, for 2500 gourdes, I shilling, payable in Philadelphia and bearing interest, which the Civil Commissioner Sonthonax gave to John Congdon, captain of the brig Polly, in payment for flour which the said Civil Commissioner forced the latter to deliver to him at Cap Français, I hope that by your solicitation I shall obtain in this matter, as in every other, the justice I think I deserve in my capacity of citizen of the United States, where I have lived for twenty years. I could have applied directly to the Federal Government, but as I have a strong attachment for the French cause and it seems more prudent for me to observe as much secrecy as possible in this matter, in view of the infamous and piratical character indulged in by the officers of the French Republic, at that time in power at Guadeloupe, both towards my brig Kitty and her cargo, and towards the Captain and crew of the said vessel, whom they not only treated with the greatest possible inhumanity by depriving them of food and having them imprisoned but also by allowing these unfortunate men to be robbed (just as if they had been taken by an Algerian pirate) that is to say, down to their last shirt. These circumstances have induced me to apply in the first instance to the delegation of the French Republic 


\section{THE LIFE AND TIMES OF STEPHEN GIRARD}

in the United States, and particularly to you, Citizen Secretary, who at the time encouraged the motives which have given rise to this step of mine.

"I have been informed that the Citizen Samatan, formerly merchant in Marseilles, was recently condemned to death and his goods confiscated for the benefit of the French Republic. As I had extensive business dealings with the said firm I am their creditor for a large sum to obtain which I have sent my power of attorney to the citizens Bonnaffé frères et fils, merchants in Bordeaux, and have also sent them certain drafts on the French Treasury. Permit me in this matter to request you to continue your good offices and aid my friends in Bordeaux in the recovery of my funds."

While Girard was engaged in writing these letters, his uncertainty as to the fate of Samatan was increased by the arrival of a ship which brought two letters from Genoa, written in January and February by Citizen Delon long in the service of Samatan.

"You are doubtless aware," wrote Delon in the first, "that our National Convention has issued a decree forbidding all French citizens to have any commercial relations with foreigners. That being the case, as I am unable to attend to my affairs in Marseilles, I have decided to come here where I can do effective work. You will therefore correspond with me in regard to the transactions we have under way and will receive orders only from me."

In the second, also written in the name of Samatan, Delon said: "As I have told you the unfortunate condition of affairs in France have induced me with my partner's consent to come to Italy in order to enable me to wind up all my foreign affairs. You will, therefore, in future, correspond only with me and send me as soon as 
possible a statement of your account with my firm. If you have received any consignments and shipped them to France for the account of my firm, I will ask you to claim them as if they belonged to you, and if by good luck you have received some not shipped, then please suspend operations and wait for orders," from a friend going to Philadelphia.

"I shall not conceal from you, my dear sir, that the tone of your letter," Girard replied, "and the rumors current here about M. Samatan have given me great uneasiness as to the fate of my old friend. I beg you very earnestly to reassure me on this subject and to tell me what misfortunes have overtaken a firm, the head of which always honored me with marks of his confidence and friendship."

"As for my Marseilles account with you, you must understand that the said account had its origin in the books of your firm, and that I cannot therefore make it out until after you have sent me the following accounts.

"Account of sale of my brig La Virginie which, from what I learn through the letters of Captain Demay, and my brother, Jean Girard, must amount to about 90,000 livres tournois; besides the net proceeds of 400 empty demijohns, one barrel of wax, a few barrels of salt provisions and the collection of the insurance effected by your firm for my account on 30 casks and one box of wax, which I consigned to you by the ship La Félicité, as well as the proceeds from the suit about the wheat from the cargo of the brig La Virginie which was lost through the collapse of the warehouse.

"The unhappy war which has affected a part of our globe for a long time has proved very disastrous to me just as I saw before me the prospect of a brilliant fortune, 
clear of liabilities, which I had procured solely by my assiduity and devotion to work. Now I find myself on the eve of losing a greater part of it, owing to the unjust manner in which the belligerent powers are treating American citizens. However it may turn out, I have decided to be patient in the hope that some day or other they will be forced to do us justice."

From Trieste, to which M. Delon had gone from Genoa, "because of its proximity to France and the opinions that prevail there," he replied.

"I know that the brig La Virginie was sold for ninety (90) thousand livres paper money at a time when London exchange was $9 d$. I do not know anything about the second sale of the demijohns. The sale of the barrel of wax and the salt provisions must have taken place, but I cannot give you the account of it till order is restored France. As I left Marseilles eighteen months ago I have no knowledge of the insurance on La Félicité. It is quite probable that they were unable to get any insurance on account of the troubles existing in France, especially in Marseilles, for the past three years. It was impossible to bring the suit about the collapsing of the warehouse, up for a hearing.

"At the death of our friend 6 million livres tournois, which were in the possession of the infernal patriots, of which 2 millions were in houses and real estate, were confiscated, and this property might well be used to pay the little he owed. I have no doubt that if you are backed by the protection of Congress you will get satisfaction.

"Several of the powers treat the French émigrés very badly. Innumerable decrees have been issued depriving them until peace is restored, of everything they thought they had saved. The widow and eight children of our unfortunate friend would be without even the necessaries 
of life if I did not send them enough to live on out of my private means.

"I am very sorry to hear of all the troubles you are having. A man who has lived and knows something of the past cannot help being astonished every moment by the events of the past few years. These infernal Court intrigues, dictated by ambition and private interest, bring suffering on the nation and ruin to private citizens, not to mention the harm it is doing them, and will do them, in the future.

"As you say, we must be patient, and pay whatever we can. You have no idea, my dear friend, how much the Samatan family is losing by this business. I have worked for this firm 15 years in the hope of increasing my patrimony. I had never drawn anything out of the firm, and just as I was intending to return to my native country and enjoy the fruits of my labors, the revolution forced me to change my plans. I have lost about 400 thousand livres through the downfall of this firm."

When the Convention, obedient to the demand of the Paris mob, expelled the Girondist deputies on the second of June, I793, it sowed the seed from which sprang the great uprising, in the Provinces and cities, against the - tyranny of the Jacobins. In that revolt Bordeaux, Marseilles, Toulouse, Grenoble, Lyons, took their part. Lyons was besieged and captured in October; a horrid vengeance was wreaked on those of her citizens who had defied the Mountain; Bordeaux and Marseilles, overawed by the fate of Lyons, opened their gates to the troops of the Convention; and in the dreadful days which followed, when, to be a man of wealth and influence was to be an enemy of the Republic, Samatan was guillotined and his property confiscated.

Now that Girard was sure of the death of his old friend, 


\section{THE LIFE AND TIMES OF STEPHEN GIRARD}

he made haste to secure himself against loss, and wrote Bentalou, "You have heard of the execution of poor Samatan of Marseilles. As I am a creditor of that firm, and am assured that Ghequier \& Holmes owe him about 40,000 livres tournois, I enclose my power of attorney and a letter to the same gentlemen." Bentalou was to make a seizure in Girard's name of all funds and property belonging to Samatan, in the possession of Ghequier $\&$ Holmes and also in the possession of Stewart and Plunket.

So the matter stood when in January 1795 Stephen Cathalan, Jr., American Consul at Marseilles, wrote: "I doubt not that the unmerited and unhappy End of $M$. Samatan's Life, when you will have learned it, will have provoqued in you the same effects of sorrow, and concern as all his friends in Marseilles or elsewhere. In that horid Period of Terror commanded by the Robespierests scarcely any body had his Life Insured! But Samatan had rendered so eminent services to his Country that it ought to be expected he would be spared; it is a real loss which is now too late repented even by his own enemies, who find it is very difficult to have now a Merchant in France to Repplace him, as he carried out the most extensive trade with all Parts and Provided abundantly his Country with all sorts of most necessary articles. he has left a widow very Respectable and a large Family, which often having enjoyed of a Decent Property, are now repenting the want of a tender husband and Father and have lost with him their Fortune.

"You was his Good Friend as I, and I take the liberty of proposing you that If you intend to continue to make consignments to Marseilles and Confide them to my care I will divide the commission with the widow of Samatan and his children: They will not know this Proposal I 
now make you, but when I will offer them their share of the first consignation you will have made to me."

The distress of Mme. Samatan moved Girard deeply and in April 1795, soon after the receipt of the Cathalan letter, he wrote to the widow: "Although I have not the honor of your personal acquaintance, the ties of friendship and common interest which so long cemented a common confidence between M. Samatan and myself are my excuse for taking advantage of the first opportunity to offer you my.services and entreat you to dispose of me freely.

"I have heard that my old friend left a numerous family and if among them there is a boy whom you would be willing to entrust to me, I assure you that I shall take the best possible care of him and that, as I am childless, I should make it my duty to be a father to him."

Most happily, there was no need of such aid as proposed by Cathalan and Girard. From Trieste, Delon wrote in August: "Made Samatan has at last obtained the justice due her honorable family which has been overwhelmed by undeserved calamities. All the property of her unfortunate husband has been restored to her, and she has been appointed executrix and guardian of her children. As soon as that was accomplished she began to liquidate the French business, paying out at least 2500 thousand francs which the firm owed, and she is now about to settle the foreign business."

"As soon as our accounts are settled I suppose you will raise the attachment you placed wherever my firm had funds. Your conduct in this respect is hardly that of an old friend and I confess I never expected it from you."

It was late in December $\mathbf{I} 795$ when this letter reached Girard, who immediately wrote Mme. Samatan expressing his pleasure "that the French nation has reinstated you in your right" and assuring her that, "Although 


\section{THE LIFE AND TIMES OF STEPHEN GIRARD}

M. Delon writes to me as if he did not know my principles, you may rest assured that I shall keep up my friendly regard for the firm of a friend whose memory will always be dear to me."

Ghequier \& Holmes replied that a year or more ago they had paid into the hands of Oliver \& Thompson all they owed the Marseilles house, and Bentalou wrote that Stewart and Plunket owed nothing to Samatan.

Writing of his losses in July, 1794, he said to Bentalou:

"I am very sorry to hear of the losses sustained by our friend Dumeste and hope that the privateer that he has fitted out will make the English disgorge and make up for the losses they have caused you. As for me I have no such resource. In Bermuda the brigands recently confiscated one of my vessels with her cargo as she was leaving Guadeloupe though it was perfectly well known to them that she is American property. I estimate the loss as at least 24,000 gourdes. The French treat me almost as badly. Besides the rich cargo they confiscated in Guadeloupe they retained in Bordeaux, and are perhaps still retaining my ship with a complete cargo for my account, and by way of improving matters, they have just seized and taken to Morlaix the ship Kensington, from our port, by which I had sent a large consignment of sugar, coffee and indigo. This conduct of theirs gives me sound reason to complain of them, but does not in the least alter my zeal and attachment for the cause which they are defending."

No little satisfaction, therefore, was afforded him by news of the recapture of Guadeloupe by the French.

"I have good news, my friend," he wrote Bentalou. "The island of Guadeloupe has been retaken by the French. The report which was brought by the ship 
which arrived here on the 2 nd instant (June) from SaintMarc is trustworthy. We are assured that Port-auPrince was taken, and it is added that Paul Verel and Sonthonax have gone to Jacmel with an army of negroes. So long as these men are at the head of the French revolution all the forces the English can bring against them will not suffice to conquer the island of San Domingo."

The value of his coffee, indigo and sugar on the Kensington was £6r 29, I0, 2d. Pennsylvania currency.

And now the tide turned, and before July ended the Sally arrived from Kingston and the Good Friends was safe at the wharf in Philadelphia.

The Sally had been seized under the Orders in Council of November 6th, 1793; but they had been revoked by the Orders of January, 1794, which established the "direct voyage" and permitted vessels of the United States to go directly from their own ports to those of the French West Indies and come directly home with products of those Islands provided the cargoes they carried were not owned by citizens of France. The English packet boat bearing this news reached Jamaica in May. "The packet so long looked for, "wrote Captain Cochran, is come at last and with suartaine accounts that the Order of the Sixth of Novr., for sending in all Neutrall vessels is revoked, and on the strength of which the Agents for the King's ships and privateers has delivered up several American vessels, they paying all charges, which a number of Americans has done since the arrival of the Packet which was the $2 \mathrm{~d}$ of this month. And this day I aplyed to James Kingston to deliver me the Brig and Cargoe which he had lybiled so unjust and he has partley agreed to deliver mee the Brig. But said he was determined to trye the cargoe and the tryall will not come on until the midal of July and my attorneys Paterson \& 
Henry advises me to take the Brig and proceed home. But that I cannot do if he gives her up untill she is hove down and perhaps sheathed as her Bottom is so much destroyed by the Worms which will be a heavy expense in this place and I am entirely at a loss how to act as this will not give mee my cargoe for Kingston still persists that you are a Frenchman and will not give up untill tryed therefore you govern yourself by sending out your seartifycate of being an American subject before that Independence was declared in America."

It was late in May when Girard received his certificates of citizenship from New York, and before they reached Kingston, Messrs. Bridgman \& Hall wrote, June 2nd:

"We hope you will have the pleasure of receiving this by the safe arrival of Captain Cochran who returns with the Brig Sally and her cargo. It will be unnecessary for us to enter into a particular detail of the circumstances which occasioned the cargo being given up, as Captain Cochran is sufficiently acquainted with them and will be able to fully inform you." Their bill for services was " $\$ 780$ equal to $£_{1} 80$ sterling."

No such good luck befel the Polly. Mr. Gardiner reached St. George, early in June, the day before the Polly was condemned. It was then too late to stop proceedings, and after the court had awarded the ship and cargo to the owner of the privateer he wrote that the best he could do was seek to recover the property by purchase. "I shall make every endeavor to purchase the vessel provided she can be purchased cheap and shall in a particular manner attend to the purchase of the cargo if I can get permission to send it to America which has lately been refused since they heard of the Embargo in America, but unfortunately for us we have one of the 
closest men in the Island to deal with, therefore I expect no favor from him."

Gardiner could not effect a purchase as "the governor has come to a determination that no West Indian produce shall be exported from this Island unless the same vessel that takes it off has brought provisions here which puts an end to the Business in our case."

The story told by Jean Girard of his adventures in Bordeaux makes a long and tedious narrative of quarrels with the Captain of the Good Friends, the mate, and the crew, as worthless a set as ever sailed a ship; of appeals to the administrators of the District of Bordeaux; to the Citizens, Mayor and municipal officers of Bordeaux; to the Committee on Subsistence and Supplies; and to the Citizens Representing the People in session at Bordeaux, for leave to load and sail away; and how, after "getting rid of the worthless Captain" he "succeeded in stealing out of France with his ship and nearly all his money." Just how this was done he would tell his brother "by word of mouth."

He also reported that the estate of Pierre Girard had been settled; that the share of Stephen was I0,673 livres, and that Samatan had been guillotined and his great fortune confiscated by the government. 


\section{CHAPTER VII}

THE LIBERTY, VOLTAIRE AND SALLY BUILT

Where to trade Girard was now at a loss to know. Seizure of his ships by the French and British, the political turmoil, poor prices and payment in drafts on the French Minister in the United States, forced him to abandon the San Domingo markets. The long embargo of the Good Friends at Bordeaux and the death of his friend Samatan of Marseilles turned him from France.

"I had intended to have my ship Good Friends continue her voyages to Bordeaux," he told Bonnaffé frères, "but the long stay she made in your river this last voyage, has caused me to think seriously and I shall certainly give her a different destination."

The North Sea ports offered no inducement for trade. Said Parish \& Co. of Hamburg:

"The French have conquered all the Austrian Netherlands and are now attacking Holland, with a very formidable army. These rich and important Provinces are defended by what remains of the allied Armies, the troops are however not only much harrassed, but also so greatly reduced in number, from the long and bloody contest, that there remains little doubt that they will also be obliged to yield here, to the superiority of their victorious, always increasing Enemy. The Probability of this event has naturally occasioned general alarm in Holland. Trade is there totally at a stand, and much property removing to this place. Several of our friends in Amsterdam and Rotterdam have come to the Resolution to land no more Goods, and have in consequence sent forward to us different Ships which we are now discharg- 
ing. This Place has thus become the Asylum, and, in a manner, the Emporium of the North. Such an important and sudden increase of Trade must naturally at first occasion a Glut and great depression of prices, however, as the quantity of the imported Articles is not augmented, but only the Channal of their Importation altered, the Consumption will soon follow, and take off the Redundancy."

Some small shipments to Amsterdam, made earlier in the year on shares with Frazer \& Co., of Philadelphia, and on his own account, in ships owned by others, had most fortunately been sold before the attack on Holland began; but no inducement now existed to send more. Week after week, therefore, passed with the Good Friends tied to the dock.

"My ship is still in the river, and I do not know what to do with her," he wrote Bentalou early in September. "Our flag is exposed to so many risks from the English that I am completely disgusted at this moment with all kinds of expeditions." For a while he thought of the Isle of France and asked Bentalou to send him a price current of its markets. Late in September he was still "waiting for a favorable outlook before despatching this vessel." When October came he had grown impatient and wrote Bentalou:

"The time for making up my mind about despatching my ship has come. Winter is approaching with rapid strides and the time is too short to permit me to wait for uncertain news. I will therefore ask you to send me whatever news you have received, especially from the Isle of France. If you will add a list of commodities, both from Bordeaux and this continent, which you think would find a ready sale there, you will render me a service.

"There is a rumor in town that a contagious disease 
prevails at Baltimore. As the news has alarmed our citizens to such a degree as to cause them to hold meetings for the purpose of taking whatever precautions circumstances demand, I will ask you to tell me as a friend whether the epidemic is dangerous, what daily mortality you have, and what are the symptoms of the disease. In short let me have your ideas on the subject.

"Our physicians have made the most strenuous efforts to convince our people that what they call yellow fever is prevalent in Philadelphia."

Bentalou did not think well of a voyage to the Isle of France. The end of the year was a good time to set sail on such a voyage, but "a moments reflection on it seems to me to convince any one that the political situation of the United States makes it imprudent to risk any important expedition during the present crises. We see our army on the frontier ready to engage in hostilities, if it has not already done so, as seems probable, with an English garrison." The army alluded to was that under General Anthony Wayne which in August 1794 fought and crushed the Indians at the Rapids of the Maumee. We see "Our Envoy Extraordinary in England being amused, and our vessels continually taken into English ports where they are condemned. Our Congress is to assemble on the first Monday of next month. When the presidents message is read Congress will certainly not be slow to express its full resentment, and then, it seems to me you will be able to make your precautions accordingly.

"Nothing proves the cowardice and ignorance of American doctors so much as the terror with which these wretches have bewitched the heads of the weak denizens of this town. It has done incalculable harm to commerce and in the present contingency they are to blame for the 
fact that many houses will be forced to suspend payment, and that $I$ assure you without the least reason. Mortality during August and September was 5 per day, and the victims were sailors at the Point, most of whom died from want, or certain persons who lived in their storehouses, and at the water front on marshy foundations. The poor devils caught bilious fevers there, which, for the most part, were improperly treated by the ignorant and therefore carried off their victims and that is what we see, practically, every autumn. The dry land and high lying land has not been effected at all."

"I note with pleasure," Girard replied, "that the mortality which we have been told here prevails in Baltimore, has been misrepresented, and I shall not fail to communicate your information to my colleagues, the health inspectors, so that we may discontinue as soon as possible the suspension of communication which exists at present between your city and ours.

"Nobody is more familiar than I am with the ignorance of American physicians. I may even say that if a few citizens had not put a stop to their infamous conduct last year they would have ruined the City of Philadelphia."

"You must not blame the health inspectors of our city for the interruption of communication between your city and ours. It would not be wise for us to take a hand in this matter; but our citizens have been so much alarmed by letters written by certain charlatans and ignoramuses in your city, and by certain other letters written by persons who, frightened at the thought of a contagion which has never existed on this continent, that they have called a meeting and have appointed a committee which, being representatives of those who believe in the contagion, have taken it on themselves to place guards \&c. in order 
to stop commerce which is much more useful than the entire faculty of Philadelphia. I assure you, my dear Bentalou, that I am doing all in my power to put an end to this nonsense and to convince my fellow citizens that the best preventive measures that could possibly be used against their pretended contagion is to take care of the sick, especially the poor, or to be more exact, the most useful class of men who, by reason of poverty, lack the first necessaries of life which lack is often the cause of the great mortality in that class."

In the course of his correspondence with Bentalou, he announced his intention to build a home on the lot 23 North Water Street, bought in the spring of 1794 from Mr. Thomas Leech. The architect was to be Major L'Enfant, still remembered as the man who planned the City of Washington, and in hopes of securing his services Bentalou was asked for a note of introduction.

"As I am about to build a house and you have told me that you knew M. L'Enfant, I beg that you will send me a letter of introduction to him."

When none came he wrote a second letter saying, "I have asked you for a letter to M. L'Enfant. Please send it by return mail."

"I do not know what you mean," was the reply, "when you ask me for a letter to L'Enfant. I never received anything from you that refers to this in any way. Explain yourself better, or for the second time, if you have already done so."

"As to the letter to which I refer, in renewing my request for a letter to M. L'Enfant," Girard answered, "I did actually write you such a letter on the _-. The occasion for this request is that I have bought a lot in Water Street, on which I propose to build, and I asked you for a letter of introduction to the said M. L'Enfant, 278 


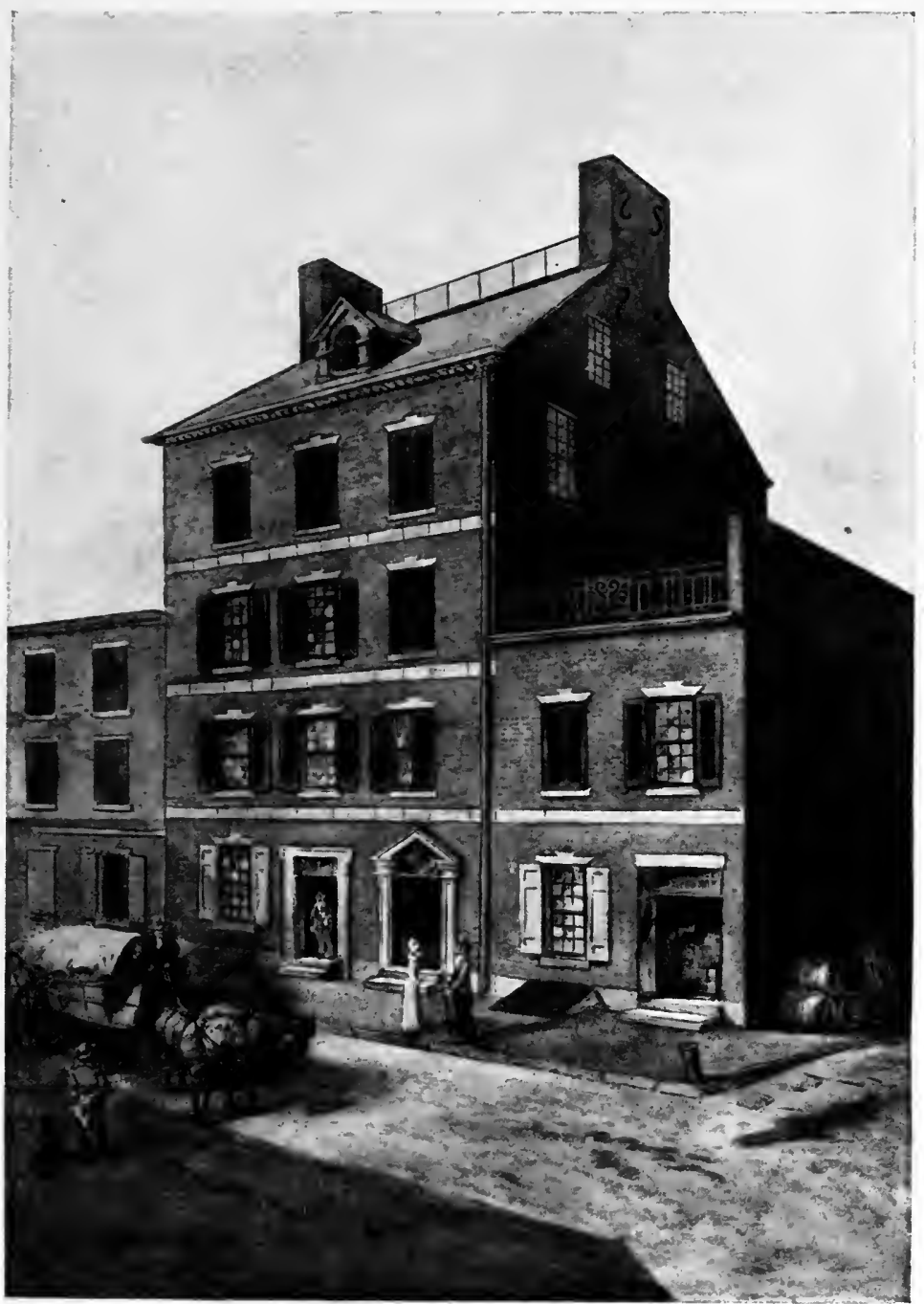

23 NORTH WATER STREET

Built in 1795 

whom I believe you know quite well, in order to get a plan from him for the said building."

And now the reason why Bentalou failed to receive the request came out. He must, he said, make his excuses for his "wife's thoughtlessness."

"My friend, Van Wyck, did not fail at the time to send her your esteemed favor of the 25 th instant (July), and she has taken such great care of it ever since that it has remained in perfect security at the bottom of her pocket until the present moment when it sees the light of day for the first time. Fortunately I am not jealous, otherwise such a piece of thoughtlessness might be calculated to make me seriously uneasy and arouse in my mind a suspicion that a more fortunate mortal than myself had turned her head. *** Enclosed you will find four lines to L'Enfant which you may use if you see fit to do so. You do not need to be warned by me not to allow yourself to be drawn into too great expenditure."

The house was built during 1795 and occupied sometime in August 1796, when he explains his delay in answering Mr. Douglas by saying that he had "removed his counting house" and that his papers "were a little deranged."

The house was long since pulled down to make way for warehouses. It was a four story, brick structure with a sloping roof surmounted by a railing and flanked by two great chimneys, one on either side. On the first floor front was his private counting house or office. On an adjoining lot was the public counting house where most of his commercial business was done.

Acting on the advice of Bentalou the meditated voyage of the Good Friends to the Isle of France was abandoned and the ship was sent to Virginia for wheat and tobacco. While she was receiving her cargo at Broadway 
on the James River, Girard heard of the British Order in Council of January 1794 which permitted neutrals to trade directly between the ports of their own country and those of France, decided to despatch her to Bordeaux, and consigned her to Joseph Fenwick, United States Consul at that port. Late in December she sailed from Virginia with 10,409 bushels of wheat and 70 hogsheads of tobacco.

The lost Polly and Kitty were replaced by a brig then upon the stocks and by the purchase of the Nancy. She had one deck, two masts, was fifty-seven feet long, measured $9375 \% 95$ tons and cost $\$ 3400$. Placed under the command of Captain Paul Post, insured for $\$ 3500$, and carrying a cargo insured for $\$ 10,000$, the $N$ ancy, as the year closed, was despatched for St. Bartholomew and a market. The cargo was not to be sold unless at an advance of $40 \%$ on the invoice valuation of $\$ 12,639$. If this could not be done the Captain was to go "to any neutral or other ports or islands not blockaded by any of the powers at war," and there sell for the best advantage, and return with green coffee. The Sally had sailed for any port in the West Indies, in July, and nothing was heard from her till she returned one day in November from Aux Cayes with sugar, coffee and cotton. A month later she too, sailed for St. Bartholomew, or a market in the West Indies, with a cargo valued at $\$ 23.414 .77$

While Girard was busy watching the unloading of the Sally one of his bond servants, a West Indian boy named Crispin, ran away. As soon as his flight was known letters were written to John Ferrers in New York and Paul Bentalou in Baltimore enclosing descriptions to be inserted in the newspapers for a week. "As I have reason to believe that some evil disposed person has persuaded him to leave my service," he wrote Bentalou, "I 
shall be delighted to have him back at any price. If you succeed in discovering him have him put in prison until further notice from me and have the goodness to prosecute the person who instigated his escape." Further investigation led to the belief that Crispin had gone to St. Thomas, and Jean Girard wrote to a friend: "A young Indian about 16 years old, belonging to my brother, Stephen Girard, escaped and left for St. Thomas at the same time you did. He has probably been enticed by some Frenchman under the influence of the new ideas, and I request you in behalf of my brother to claim him and send him back. He will pay all costs and the return passage.

"His name is Crispin, height $5 \mathrm{ft}$. 2 or 3 inches; slender build; erect gait; color swarthy; hair long, black and thick; countenance smiling. He usually wears a national cockade made of ribbons cut in the shape of a carnation. He had a new waist-coat and trousers of coarse, hairy, iron-grey cloth with metal buttons, white, like stars, and a Bearn handkerchief around his neck. He speaks French and English.

"I suspect that he left either with Captain Robertson, on the brig Sophia, or more probably by the Brig Franklin, Captain Reynolds, having followed Larelle part owner of the vessel."

A postscript added by Stephen Girard states, "From various inquiries I have made I am led to believe that the said Larelle, owner of the brig Franklin, is the person who stole my Indian."

A similar letter was written by Jean Girard to M. Vignes at Jérémie, where the Franklin was to touch, and to this also Girard added a postscript setting forth that, although he owned the Indian but for a certain number of years, after which the boy would be free, nevertheless he would gladly sacrifice 300 gourdes to have him back 
in Philadelphia. To M. Vignes was sent a power of attorney to enable him to make the arrest and prosecute the rascal Larelle; a certificate from the Mayor of Philadelphia proving that Crispin was legally bound to Girard: "A sworn statement of M. Perot of Léogane; the sworn statement of the boarding-housekeeper where the rascal Larelle stopped; the sworn statement of a servant named Caesar proving that, at the moment when my Indian decamped a man whom he describes as Larelle called him from my house and spoke to him on the pavement: and finally the sworn statement of my brother" that Crispin had sailed on the Franklin for St. Thomas.

Bentalou was now requested to stop the advertisement in the Baltimore newspapers and write urgent letters to Messrs. Eckard \& Co., St. Thomas, and the American Consul at Curaçoa begging them "to use every means to capture the fugitive regardless of cost." Mr. Ferrers was notified to the same effect and asked to send to his correspondents in St. Thomas a description of the boy, and an offer of $\$ 100$ reward for his capture and $\$ 200$ for that of Larelle, to be inserted in the newspapers of all the Windward Islands, and Captain Post, of the Nancy, was instructed to make inquiries as to Larelle and the boy at the very first port he reached in the West Indies.

Information now reached Girard that Larelle had gone to Williamsburg, Virginia, whereupon Mr. William Douglas was provided with documents and urged to spare no expense in sending an express to Williamsburg, "where you will request one of your friends to make particular inquiry respecting my Indian boy and the thief, Joseph Larelle; in short track them through all the Southern States." The description of the runaway, 
as sent by Mr. Douglas to Mr. Leroy Anderson an old clerk, then a storekeeper at Williamsburg, was, "the boy's name is Crispin; about 16 years old, 5 feet 4 inches high, slender mode, walks straight, straight black hair which he sometimes ties, speaks french and broken english, run away from his master Mr. Stephen Girard of Philadelphia, the $15^{\text {th }}$ of Nov. last, where he had lived about three years, he had on when he went away an almost new black hat, new short jacket and a pair french fashion trousers with feet to them made of grey coating, with plated buttons, white shirt, french neck handkerchief and an almost new pair of shoes tied with ribbons, and wears sometimes a national cockade. for securing the Boy in jail I will give Twenty Dollars."

Two buttons similar to those on the coat worn by Crispin were sent to Douglas and a couple to Bentalou who was asked to write to some friend in Virginia and get information, secretly if possible, through some negro. "You see that I am willing to play the game to the end without sparing money. Indeed, I confess this theft has annoyed me exceedingly, especially as I have always treated the servant in question with all possible humanity and gentleness."

And again "please spare no pains or expense, I assure you this theft has annoyed me more than if I had lost a hundred times its value in the course of business."

And now came news from William Douglas. "I had to-day an express from Williamsburg informing me that Larelle was there, but no account of the Indian boy." Steps were at once taken to secure the arrest of Larelle and in the next letter Douglas states: "Your Indian boy, Crispin, was taken up in Norfolk on the first advertisement and is now in jail there in my brother's care. He denies any knowledge of you but says, $\mathrm{He}$ is from Phila- 
delphia where he had been at school and calls himself Henry Hill," and had a certificate signed by Captain James G. Coppinger of the Danish Ship Henrietta that he came from Philadelphia as a passenger.

Orders were now sent to have Captain Coppinger arrested and prosecuted for carrying away a bond servant, and to give to the poor of Norfolk whatever damages the court might award.

Larelle meantime had seen the advertisement in the Williamsburg newspaper and fuming and storming with rage had called on Douglas and threatened suit, for defamation of character, and had announced his intention in a Petersburg newspaper.

"Having seen in sundry papers an advertisement accusing him of stealing an Indian Mulatto. Boy and a reward offered for apprehending and bringing him to justice but in order to bring to justice those concerned in defaming his character, and as far as possible have redress for so horrid an abuse, he has instituted a prosecution for that purpose and requests the Public in the meantime to suspend their opinion of him. Jos Larelle, Citizen of Paris."

"I suppose," wrote Mr. Douglas, "that he means to bring suit against me for defamation, indeed, I have understood so because at the foot of the advertisement I mentioned that I would pay the reward. ** At any rate it is best to be guarded, and I must request you to send me any further proofs that may be requisite either to defend a suit, if he brings it, or to prosecute him."

Such affidavits as Girard collected and sent to Douglas were by him submitted to a lawyer in Williamsburg who declared "the proofs not positive enough (although very strongly presumptive) to arrest him on, and I thought it better to await further until I heard from you. This 
inactivity has occasioned a boldness in him, and to cause his talking of commencing a suit for damages, thinking it would soon blow over."

He was quite serious in his threats and January 12, I795, Mr. Douglas wrote:

"This day the Marshall served a Federal writ of Larelle both against our Printer here and myself in each $\$ 15, \infty 00$ dollars damages returnable to the 22nd day of May next."

Girard, however, was determined to have Larelle arrested, applied to the Governor of Pennsylvania for a requisition on the Governor of Virginia for Larelle, and despatched it to Douglas with the request that he "send it immediately by an express to Richmond, and after having obtained orders from your Governor, be so obliging as to send them by express all throughout your State until Larelle is arrested and sent on to this City where I hope his conduct will be punished."

The Governor of Virginia issued the order and about the middle of January Mr. James Douglas of Norfolk wrote: "From an order of the Executive of the State this day Joseph Larelle a Frenchman, was arrested and is in close confinement in order to be removed to the state of Pennsylvania to stand tryal for the charges you exhibit against him. The manner of his removal you no doubt will inform yourself of.

"The East India boy is in confinement. I think it very doubtful whether or no he is your boy Crispin. The deposition and his arrival here does not correspond. They mention the $15^{\text {th }}$ of November, the day the boy arrived here. Some person ought to have been sent on and will still be necessary to prove the identity of the boy and Larelle."

The denial by the boy of all knowledge of Girard, 
the fact that he arrived at Norfolk the day Girard said he ran away, and the fact that he "had sold two gold watches in Norfolk, one of them old and the other a new one at 40 dollars," led even Girard to doubt that he was Crispin.

"I think," he replied, "that the buttons which I have sent to you would have decided that matter. For my own part I must confess that after what you say respecting the gold watches I believe the lad which is in jail at Norfolk belongs to Mr. Francis of this city. That gentleman had an East Indian boy named Henry about the same age and size as mine who ran away from him the same as mine and stole a new gold watch which had been given to him to carry to Mr. Powell." Nevertheless Girard was still certain that Larelle stole Crispin, and now for the first time consulted his attorney, Mr. Jared Ingersoll, as to the propriety of his action and was told, "By a careful perusal of the Affidavits I find that no person swears positively that your Boy was ever seen in the Company of Capt. Larelle.

"The letters from your friends, if accurate, show to a demonstration that the Boy who is with Capt. Larelle is not your Boy.

"It was humane in you, considering the suspicious circumstances, to pursue the supposed Delinquent, but if you have erred in Judgment the mistake should be corrected as soon as possible.

"I wish that you had given me more time to think of this business, as it wears a serious aspect.

"I would advise you to write to your Friends in Virginia to attempt a compromise with Capt. Larelle, become his bail for his appearance here, if that will be taken there, or receive him into their custody to bring to this city and then settle matters with him. 
"I would then write to the Executive of Virginia, inform them that suspicions against Capt. Larelle were not proved, and would endeavor to explain the matter as might save the person who should undertake to Conduct the Prisoner to this state from incurring penalties."

Still he was not convinced of the innocence of Larelle and undertook a piece of private detective work to get proof of guilt. There had just entered his employ a young man named J. H. Roberjot, "one of the Cape sufferers and a patriot." As such he interested Girard, who seems to have promised him employment as bookkeeper as soon as he knew sufficient English, and having acquired this knowledge by November of I794, Mr. Roberjot sent this specimen:

"When you did me the favour of speaking to me concerning the keeping of your books, I observed to you, that I expected not to be master enough of the English idiom, in order to keep them in English. As you have been so kind at my last journey to Philadelphia, as to shew me a desire, that I might come and work in your counting house, I am very willing to do it, in so far my writing and my English might answer the purpose; if so I shall be very much obliged to you, to let me know it. I shall endeavor to keep your books in the best order, as well as to do every business in my power, the best of your Interests will require from me. You know, Sir, what a man is wanting for an honest living in your Town, therefore I shall not make any conditions with you. I leave it entirely to you, to fix the maintenance you will grant me, and shall be happy to work under such an enlightened man as you." Employment was given and in the course of thirty-four years of service Mr. Roberjot became not merely a bookkeeper, but his trusted agent in affairs great and small and in general his man of business. 
Almost the first service assigned to him was a secret mission to Norfolk to persuade Larelle to confess. "I cannot," Girard wrote early in February, "too strongly impress on you the necessity of keeping the object of your mission as secret as possible. Try to get something to do from the French Consul, pretend to become J. L's confident and intimate friend, and, after you have sufficiently convinced him that his case has taken a bad turn and that his situation is critical, point out what risks he takes and how much he needs the advice of a trusty friend without, of course, appearing to wish that he confide in you. Tell him that if you were in his place you would extricate yourself from such a predicament without loss of time, even if you had stolen the Indian and sent him to the colonies to be sold as a slave. If he asks you how, you might answer him that you would confess that the Indian had come to you several times pretending to be a free man and had represented that he was living in misery in Philadelphia and wished to go to the colonies; that you had taken pity on him and had procured passage for him on board the ship

Captain bound for

"In short, do everything in your power to get from the scoundrel an avowal of the truth."

Roberjot obeyed his orders, and, Girard told Douglas, "had a long conversation with Larelle who positively denied ever having seen my boy Crispin, and manifested his intention of prosecuting you, the printer and me, but Mr. Roberjot having represented to him that I had written to every port in the West Indies, he told Mr. Roberjot that he would agree to settle with you in the following manner-He will abandon all demands whatever provided you will contradict what you have said in the newspapers and pay charges. I flatter myself you will 
not make such arrangements with him, particularly that of denying a crime which he has committed and of which I am fully persuaded."

Larelle was finally brought to Philadelphia, and a true bill found against him by a Grand Jury. But the trial dragged along, as did the two suits begun by him in Virginia against Douglas and the printer of the newspaper. At last, in March of 1796, these latter were dismissed because Larelle failed to give security for costs. But not till November I 797 did Girard write to Douglas "I have at last settled with Joseph Larelle."

The runaway during all the search was safe in San Domingo where, Mr. Genty Lavaud told Girard he saw the boy at Port-de-Paix, in the service of citizen Danby the supercargo on a privateer from Charleston. Girard thereupon, wrote General Laveaux, commander of the troops at Port-de-Paix, setting forth that Crispin was "bound over to me according to the laws of the state of Pennsylvania to serve for a limited time," that he had been enticed away by Joseph Larelle and had been seen at Port-de-Paix. If Laveaux would give orders to have Crispin sent to Philadelphia that he might testify against Larelle, Girard would see to it that the Indian was returned "immediately after the end of the trial."

"You must know very little of me," replied Laveaux, "to dare to hope that in defiance of our glorious constitution I would consent to force a man against his will to leave the land of liberty where he has taken refuge.

"No, citizen, I cannot do what you ask of me-arrest the citizen Crispin. In coming to Port-de-Paix he has come to enjoy liberty. In Philadelphia he was a slave. Have I a right to order him to take up his chains again? Assuredly not.

"However useful the presence of citizen Crispin may be to your friend Girard, I cannot break the laws, espeVol. I-19 


\section{THE LIFE AND TIMES OF STEPHEN GIRARD}

cially the one relative to liberty. All I can do is to request Crispin to make a declaration before the judges of Portde-Paix, and you may do with it what you can."

The year 1795 opened with the Good Friends on her way to Bordeaux, the Sally and the Nancy still unheard from, and the Liberty on the stocks.

The Nancy was captured by a French privateer, and taken to Petit Canal, Guadeloupe, where the captain was forced to sell her cargo to the Government for such prices as it choose to give, take his pay in sugar, coffee and cotton at such values as it saw fit to allow, and wait for the goods till it was pleased to deliver them. It was May when she returned to Philadelphia.

The Liberty by that time had been launched, and another ship for Girard was on the stocks. The Liberty having been loaded with a cargo valued at $\$ 41,129$ was placed in command of a Captain transferred from the Nancy, and was despatched to Bordeaux. He was to place the goods in the hands of a responsible house, go to Paris, and deliver to James Monroe, then Minister from the United States to the French Republic, some packages from the Secretary of State, and a letter. In one of the packages were vouchers for the claims for damages Girard proposed to make on France. Just what these claims were, and the amount of loss and damage in each case, had been fully explained in a memorial from Girard to the Secretary of State, and it was the vouchers sent with the memorial that the Captain of the Liberty was to carry to Monroe.

Girard complained in his memorial that his brig Kitty had been seized and captured by a French privateer, carried into Basseterre in the Island of Guadeloupe, and though duly discharged by the decree of a Court of Admiralty, as taken without just cause, ship and cargo were 
afterwards "arbitrarily detained, confiscated, sold and the proceeds appropriated by the Governor and Intendant of the island whereby," he suffered a loss of $\$ 30,669.5 \mathrm{I}$. He complained that the ship Good Friends was held at Bordeaux "in consequence of an Embargo by the French Republic from the month of September, I793 to the month of April, 1794; that this detention which forced the Captain and supercargo to unload the homeward cargo, to sell part thereof, and incur many other expenses produced a loss of 34,696 dollars six cents of which the Republic has made a partial indemnification amounting to 1148 dollars and 95 cents."

He complained that the Kensington having on board property of his was seized by a French privateer, carried into the port of Morlaix, and "arbitrarily detained from the 28th of April to the 8th of October 1794 when she was permitted to pursue her voyage," causing him a loss from "delay, wastage, depreciation of quality, and other causes" of $\$ 4067$.

The brig Polly "being at Cape Français in the Island of Saint Domingo, with a valuable cargo" belonging to him, "the administrators of the Government under the pretense of public necessity seized and appropriated to their use a variety of articles and in payment thereof drew nine Bills of Exchange" in his favor. Drawn on the Treasurer of the Marine Department of France for $\$ 8,847.55$, they were presented and registered on July $2 \mathrm{I}$, 1793, but were protested for non-payment and returned. These bills and damages amounted to $\$ 10,617.6$.

"Messrs. Aubert, Chauveau \& Bacon of Cap Français" his Factors, having sold on his account, "a considerable quantity of flour to the public was compelled to receive in payment thereof five other bills of Exchange" for \$ $\$ 409.76$ which, with damages and interest, still remained unpaid. 


\section{THE LIFE AND TIMES OF STEPHEN GIRARD}

"Towards the close of May in the year 1793 Messrs. Aubert, Chauveau and Bacon of Cap Français, the Factors of your memorialist, also sold 150 barrels of flour to the public for $\$ 1800$, payable in cash, but notwithstanding the order for making such payment was duly registered no part thereof has been paid or satisfied."

Captain Congdon of the brig Polly having sold to the public a quantity of flour, the property of Girard, "was compelled to receive in payment therefor the delegation or draft of Sonthonax (Civil Commissory of the French Republic at the Island of San Domingo) on the Citizen Genet." The draft with interest from September 19, 1793, to December 30 , 1794, amounted to $\$ 2707.62$.

He complained further that because of the condemnation of the Kitty the officers and crew had suffered a loss "from the seizure of their private adventures, their apparel and stock for the voyage," estimated at $\$ 2,000$; and that by the seizure of the estate of.M. Samatan he was prevented from recovering from the estate a debt of $\$ 8140.7$ I due from M. Samatan.

The schooner Nancy, he complained, had been held in Guadeloupe, and her cargo taken at prices far below what could have been obtained had her Captain been allowed to seek a market, thus causing a loss of $\$ \mathrm{r}$ r, 539.46 .

From all these acts and causes he had sustained a loss of $\$ 104,498.56$, and having sought redress in every manner possible, he must "ultimately consider the Government of the Union responsible for the injuries which he-has sustained, being bound by the nature and terms of the political compact to have prevented or redress them."

Next to put to sea was the Nancy bound for St. Thomas. and a market. The first to return from abroad was the Good Friends. She arrived at Bordeaux in March, where her cargo sold for I,040,708 livres, 19 sous, 8 deniers, and 
sailed for home in June with goods worth $1,059,204$ livres, 5 sous, paid in assignats when paper was 8 for $\mathrm{I}$ in specie, and exchange 60 for i i dollars.

When about to despatch the Good Friends on her homeward voyage, Fenwick, Mason \& Co. wrote:

"Under the expectation of the restitution of Estates of the condemned merchants during the reign of Robespierre we were prevented bringing forward your claims on the M. Samatan's estate. This decree has just past, and the Heirs of all the condemned in that class (except for emigration) are to be put in possession of their father's estates. Therefore you no doubt will recover what is due you by Samatan, but at the present rate of assignats we advise by all means to suspend your reclamations so as to avoid the effects of the Tender Law that obliges you to receive assignats at par."

At the time of the arrival of the Good Friends in July, Philadelphia was seething with excitement over the Treaty with Great Britain. It was signed in London in November, and copies sent by two of the London packets; but not till the seventh of March 1795 was one of them placed in Washington's hands. Congress having adjourned three days before, a proclamation was issued summoning the Senators to meet on the eighth of June, and on that day the document was laid before them to "decide whether they will advise and consent that the said treaty be made between the United States and His Britannic Majesty."

The Senate consented, and on the twenty-sixth of June, after enjoining the members not to allow a copy of the treaty to be made public, adjourned. One article which would have borne heavily on our trade was rejected. By this it was "expressly agreed and declared that, during the continuance of this article, the United States will prohibit and restrain the carrying of any molasses, sugar, 
coffee, cocoa, or cotton, in American vessels, either from his Majesty's islands, or from the United States, to any part of the world, except the United States, reasonable sea stores excepted."

The treaty having been thus amended it was necessary to send it back to England for approval. Meanwhile it was not to be made public till such time as the President should think proper. But, three days after ratification, the substance of the treaty appeared in the Aurora. This summary was not quite correct and that the people might be truly informed, Senator Mason of Virginia disregarded the injunction of the Senate and sent his copy to the editor of the Aurora.

The Republicans were greatly pleased. Praise of Mason was heard on every hand and packages of the treaty in pamphlet form were sent by express riders in every direction. Everywhere town meetings were held, speeches made, resolutions denouncing Jay and the treaty adopted, and copies of the hated document burned. What was the character of the treaty was a matter of little consequence. It was an amicable agreement with Great Britain, assured peace and prevented us joining France in the war, and that was enough.

As news of meeting after meeting reached Philadelphia the Republican leaders decided that the time to act had come, that Philadelphia should delay no longer, and that a town meeting should be held to condemn the work of Jay and the Federalists. A handbill was therefore quickly printed and scattered about the city. It read:

$$
\text { "Town-Meeting-Treaty. }
$$

Citizens! assemble at the State House on Thursday: the $23 \mathrm{~d}$ instant, at $5 \mathrm{o}$ 'clock, then and there to discuss the Momentous Question, viz: Are the people the Legiti- 
mate Fountain of Government? There is creeping into your Constitution an insidious Serpent, whose venom, once infused, will exterminate every remaining Spark of Gratitude and National Faith! Attend! Your rights are invaded! France is our avowed Friend and in the hour of Adversity was our vigorous and undaunted Advocate. Great Britain is the universal Foe of Liberty: and you, from your Regeneration to the present moment, have been the guiltless victims of her Infernal malice."

At the appointed hour the meeting was held, resolutions denouncing the treaty were adopted; a committee of fifteen, one of whom was Girard, was chosen to frame an address to the President, and an adjournment was taken till Saturday, the twenty-fifth. The report was then read, paragraph by paragraph, and the voting done by a show of hands. Though six thousand men were said to have been in the State House Yard, no more than two hands were raised in the negative at any time. When the remonstrance reached the President it bore the signatures of four hundred and thirteen Republicans; that of Girard was among them.

Describing to Bentalou, what took place, he said:

"Tell me, my dear friend, how your fellow citizens received the Treaty negotiated by the infamous Jay. We have had a demonstration here. The Kensington carpenters and certain other hot Republicans last Saturday formed a procession, carrying an effigy of that noble patriot, through the streets of our city, and ending by burning it at midnight on one of the heights of Kensington. I am told that everything went off very quietly, except that a few light horsemen were rolled in the mud and pelted with stones. They tell me that Jay's effigy held in one hand a balance, on the upper scale of which was written, Virtue, Equality and Independence, and on 
the other English gold. Such treatment of the Executive power may not please everybody; nevertheless in my opinion it is time for the Americans to open their eyes or they may readily fall back into Slavery."

His bitter feeling against Great Britain is again expressed in a letter written to Bentalou in August.

"The infamous treaty appears to have gotten us into a pretty pickel. The English, that worthless and contemptible nation, continue their depredations with greater vigor than ever. You have, no doubt, heard of the insult offered to the United States by the ship Africa. I must say our government deserves it.

"About the beginning of last June I despatched a brig with a large cargo. As it contained, among other articles, wheat and flour, I am very much afraid these pirates have taken it to one of their harbors."

The brig was the Liberty sent to Bordeaux with a cargo valued at $\$ 4 \mathrm{I}, \mathbf{1} 29.25$. The Africa was a British ship of war that for some time past had been lying in wait off Narragansett Bay to catch the French frigate Medusa when she came out from Newport. Now it so happened that M. Fauchet, the retiring French Minister, was going back to France on the Medusa, and late in July was sailing up the sound on board the sloop Peggy bound for Newport. Head winds and storms forced the Peggy to put in at Stonington whence M. Fauchet went on by land. The Peggy soon resumed her voyage and when off Narragansett light was brought to by a shot from the Africa, and boarded by a party whose commander demanded M. Fauchet. Assurance that he was not on board was of no avail. The Peggy was searched, his trunks in his cabin were broken open, as were those in the hold, in hopes of finding papers.

On the return of the Good Friends from Bordeaux 296 
she was despatched to Hamburg with a cargo of sugar, coffee and cotton valued at "about $\$$ roo,ooo," consigned to Berenberg, Gossler \& Co. and in August, 1795, set sail.

Much to his surprise, he now heard of the arrival of his lost brig, the Kitty, at Baltimore.

"By the way, I forgot to tell you about the brig called the Kitty which is now in Baltimore in the care of Mr. James Waters," he wrote Bentalou. "The vessel belonged to me and was captured in 1793 and condemned with her cargo at Basseterre by the Governor whose name is Collot. Since that time she was bought in St. Bartholomew by Mr. Vasse's Captain. I have refused to help the latter to obtain an American register and as he does not know what to do with her he has offered her to me for two thousand gourdes. The price is reasonable enough unless the above mentioned vessel is completely broken up, and I will accordingly ask you to look her up, have her examined with all possible care, and send me as soon as posible an inventory of the whole with your remarks as to price \&c., so that I may come to a decision."

In company with one of his own Captains, and "an expert," Bentalou visited the Kitty, found the rigging and standing rigging in good condition, the cables worthless, and that her bottom had been ruined in the colonies. To sheath the hulk and put it in good condition would cost $\$$ I 500 . Could an American register be obtained she would probably sell at auction just as she was, at a profit of a thousand gourdes.

"The contents of your last letter," Girard replied, "have decided me to make the purchase of my old brig Kitty. I have agreed with the owner, Vasse, to take her for 1800 gourdes. I shall send you by next mail the docu- 
ments necessary to prove that she is an American bottom; meanwhile I will ask you to look out for a good American captain." .

The Kitty was accordingly bought and documents sent to enable Bentalou to get an American register.

"It appears from all the documents in my possession that I unquestionably have the right to sell the brig Kitty under my own name, as she is a vessel that has never ceased to be American property. But my chief object is to avoid compromising my claim, as I undoubtedly should if I used my old register, and sea letters to obtain new papers, for the parties against whom I am making the claim would say that my loss never existed since the property in question never ceased to belong to me."

Once in possession of the brig, Bentalou was to sell her, if he could, for 3300 gourdes cash, or 3500 in good Philadelphia drafts at 60 days from sight. If this price could not be had the Kitty was to come to Philadelphia with freight.

"Yesterday I took possession of your brig Kitty and placed her provisionally in the care of Captain Besse. There is a despatch boat belonging to the French Republic in this harbor, at present, which is to be condemned. As the crew is idle I have told Captain Besse to take as many men as he needs, and put his rigging in good condition, unfix the shrouds, and to attend to everything else called for under the circumstances."

Preparations were now made to receive the Kitty in Philadelphia. Work on his new ship Voltaire was hurried that when she left the stocks the Kitty might take her place, and Bentalou was cautioned not to spend a cent more than was necessary. But she was not to come to Philadelphia, for Bentalou sold her to Samuel Smith of Baltimore for $\$ 3300$. 
The Nancy reached St. Thomas in August, 1795, and finding no market the Captain set sail for Fort Dauphin, but put in at Le Cap instead, where the government took fifty barrels of flour at $\$ 14$, ten of pork at $\$ 20$, and ten of beef at $\$ \mathbf{\$} 2$, and then gave permission to sell what remained of the cargo. "The time of payment," said the captain, "is uncertain, but I fear it will be a considerable time before I get it." Prices were low, sales were dull, and coffee very dear and hard to get, and when October came he was still at Le Cap. "I have nearly sold all my cargo but to no advantage, altho I have been more fortunate than most Americans in port. I am also sorry to inform you that from the best information I can procure I shall not be able to act agreeable to your orders respecting the purchase of a homeward cargo as it will be impossible for me to get a load of coffee. I should have proceeded further to leeward to procure a homeward cargo before this time if I had got my pay from this government, but I am fully determined to have it before I leave this port." A week passed and it was still "impossible to obtain any payment without giving a sum of money to the government, accordingly I have this day agreed to give them 2000 dollars in order to foreward it which I have now good reason to believe will be in a short time and in good sugars at 8 dollars per hundred for the cash I advanced them." Not till the night of December 24 did the Nancy reach Philadelphia. That same night the Liberty arrived from Bordeaux. "Both vessels," Girard wrote to his brother, "Have done a ruinous business."

A voyage of forty-five days brought the Liberty to Bordeaux where Captain Post wrote, that neither there nor in all France was there any possibility of selling anything even for assignats. "Produce of all kinds is much 
cheaper here than in America, the produce of this country very scars and high. I kept the cargo on board as long as I dare. For fear it would take damage have Landed it and stored it. they tell me that it is impossible for me to proceed from this to hamburg for there has been so many vessels in that business that their is neither Brandies nor wins to be had fit for that market, nor speche or Bils. their has Lately a great number of Bils Cum Back protested and from the best Accounts their wins, Brandies and West India is very lo their.'

By the first of September the wheat had been sold at 22 livres a French bushel, specie, but there was "no other part of the cargo that will sel for anything." Captain Post therefore was much disposed to send her home and stay in France till the cargo was sold. By the middle of September the cotton was sold at 8000 livres, in assignats, for a hundred pounds, the indigo at 222 livres in paper, per pound, a dollar being worth 220 livres in assignats. This money was "turned Immediately into wine so that the laus by the Depresiation was not mutch. A dollar is now worth 240 to 245 Livres in paper. The sacrafise is great but their must be some part of the cargo soold in order to Dispatch the vessel as soon as possible."

October Ioth the Liberty in command of Mr. John Ridg left Bordeaux with brandy and wine to the value of $£ 2000$ sterling. "I have done it for the best," wrote Captain Post, "and it is a very disagreeable thing to me but as you strictly ordered me to leave no part of the property behind, and as I had not been able to go to Paris on your other bisnes I could see no other Remady but to stay behind my self, settle the Bisnes in this plaice and also in Paris."

"I am really sorry to observe your anxiety of mind," was the reply. "Surely you do not presume that I expect 
you can influence the market of Bordeaux nor that you can make a good voyage when circumstances renders it impossible. No, Sir, what I desire from you is, that you will make every exertion for the advantage and preservation of my interests having particular attention to not sell, nor suffer to be sold under any pretense whatever, the remainder part of the cargo of the brig Liberty which I had consigned to you in any other way but for specie, cash in hand, and not without an advance of at least 20 per ct on the invoice. Otherwise you will keep said goods in safe store under your care until you hear further from me on this subject."

"I recommend you to not fret on my account or for any other cause whatever. No advantage can arise from making yourself unhappy. Follow your business very close, consult my instructions and interest, employ your leisure moments in recreating yourself and you will please me by so doing."

No sooner did the Liberty arrive, therefore, than preparations to send her back were hastily made, and early in January 1796 she sailed with a cargo valued at $\$ 24,962.72$ consigned to $\mathrm{Mr}$. John Hourquebie who went as passenger. "In five days of rain and sunshine," Girard wrote Bentalou, "I have discharged and shipped a cargo chiefly of flour. The vessel sailed last Monday for Bordeaux and I hope she is at sea by this time."

To Hourquebie he said, "as soon as you reach Bordeaux please at once take charge of all my business. I should be sorry to see any one but yourself in charge of any part of my interests. If Captain Paul Post can be of any use to you, make use of him without, however, allowing him to undertake any operation of his own initiative." Above all Hourquebie was to hasten the dispatch of the Liberty and send her back with a fine big cargo, and on 
no account sell "my merchandise for paper money unless you are absolutely sure in advance of being able to dispose of it to good advantage for goods suitable for a cargo."

The Good Friends, when twenty-eight days out from Cape Henry, reached the English Channel in a heavy gale which lasted three days. On the third day Captain Smith spied a pilot boat from Cowes, Isle of Wight, took on a pilot, and sailed for Dover. There a King's pilot was taken for the North Sea and Hamburg. Before the river Elbe was reached the gale had so increased that the pilot advised running into the Weser and anchoring for the night. This was attempted, but "at night the gale increasing and a heavy sea ship Rideing, jibb Boom all under, we started our anchors and driving right upon a sand obliged us to cut away our Main Mast and all there to belonging to save our Lives, ship and cargo. Immediately on finding the ship would not bring up, I spliced the remaining part of the best bower cable to the small bower and veered along shore until the ship brought up about half a cables Length of the breakers which if they had struck of consequence we should have all been lost."

"By the assistance of the fisher boats we arrived at Cuxhaven on the 2nd day of November when on Acct of the ships comeing Last from Norfolk we were obliged to ride qurenteen 12 days."

December 5th, I795, the new brig called Voltaire was launched. "I was very much afraid for this vessel," Girard wrote Bentalou, "because the ways on which she was built are new and the winds prevailing recently had prevented the tide reaching its usual level. Nevertheless everything went off with astonishing rapidity and convinced me that she is very well disposed towards me. I hope she will make some money for me. 
"I had hoped, my dear Bentalou, that after launching this vessel I would be satisfied for a time, but the unfortunate ambition that has taken hold of me, and my desire to keep busy suggests new undertakings to my mind and with them inevitably a long course of trouble."

"I congratulate you on your new vessel le Voltaire," was the reply, "and wish her every possible success. I strongly advise you to christen the next one you are going to build 'Le Jean Jaques or John James.' Under the auspices of such a sage I predict the greatest success."

For a while Girard was uncertain where to send the new ship and wrote Messrs. Thellusson Bros. \& Co. of London, "I propose commencing in a few days to load my ship Voltaire with West India produce, but I am uncertain if I will send her immediately to Hamburg or to Falmouth and a market. My next will inform you more fully."

The next requested "that you will be so obliging as to insure on my account against all risks whatever eight thousand pounds sterling on sugar, coffee, cotton and fustick on board the ship Voltaire Ezra Bowen master from Philadelphia to Hamburg.

"The ship Voltaire is a fine new ship on her first voyage, built in this city under my inspection with live oak and cedar, of upwards of Three Hundred tons burthen, and is in every respect fitted in a compleat manner. The Captain of her was formerly the master of the ship Factor of New York, one of the London traders. As that vessel is entirely my own property you may warrant her if required to be such, also to be an American bottom."

Messrs. Berenberg, Gossler \& Co. of Hamburg were then informed that the scarcity of West India produce made sugar, coffee and cotton very dear, and freight difficult to get. Hence the Voltaire would not sail before 303 
March I5th. That she might be sent back as quickly as possible they were to have ready for her, bar iron, an elaborate assortment of dry goods, four hundred empty demijohns and four thousand Holland cream cheeses. Messrs. Wharton \& Lewis, and the Insurance Company of Pennsylvania, were then requested to "insure against all risks ten thousand dollars on the ship Voltaire," from Philadelphia to Hamburg, "with liberty to touch and trade on her homeward bound passage at one or more port in Europe."

The cargo shipped on Girard's account amounted to $\$ 63,506.69$; freight on goods belonging to others amounted to £I I 20 8s sterling, and on March 24th the Voltaire set sail.

Hoping that some passengers might return in the Voltaire the captain was instructed to charge "in the cabin Twenty guineas exclusive of stores, and 30 guineas including stores, of which you shall be entitled to one fourth after deducting the cost of the stores. Every passenger in the steerage must pay ten guineas and find his own stores, or fifteen guineas and be furnished as the seamen fare with the use of the fire in day time to cook any little mess they may prefer to have done in their own way. Should the ship come direct from Hamburg and any passengers be willing to come as Redemptioners, I would have you take as many young people as you can conveniently accommodate, but do not take old people with families which are not easy to be disposed of. The Redemptioners are to be treated in every respect as steerage passengers. The price of this passage is six guineas each and find his own stores, or eleven guineas and be furnished with Beef, peas, potatoes and rice. In case the passage money is to be paid here they must pay twelve guineas. The passage money of Redemptioners as well as that of the steerage passengers belongs wholly to the 
ship. I recommend you to keep a particular look out that the passengers are not abused, molested or ill treated by any one under your command."

The country was then a second time wrangling over the treaty with Great Britain. After amendment by the Senate it went back to London where ratifications were duly exchanged in October, $\mathbf{1 7 9 5}$, and on March 2nd, 1796, Washington proclaimed it the law of the land. It then became the duty of the Congress to make such appropriations of money as were necessary to carry out the provisions of the treaty.

At once the press and the pamphleteers of both parties took sides and roused the people into a state of great excitement. If, said the Federalists, the money is not voted there will be war with Great Britain. If, said the Republicans, the money is voted there will be war with France, and each party labored hard to prove its assertion. In the House a vigorous effort was made to defeat the appropriation on the ground that the treaty was unconstitutional, unequal and disgraceful to national honor. While the debate ran on nothing was spared that could add to the excitement or influence Congress. Alarmed at the prospect of war with one power or the other, the timid took fright, business was depressed, ships were laid up, the insurance companies ceased to take risks, and in a score of towns and cities public meetings were held to adopt memorials or sign memorials to Congress. In Philadelphia the "merchants and traders" met and petitioned the House to vote the money. Not to be outdone, "a respectable meeting of merchants" opposed to the treaty, good Republicans, was held, Girard made Chairman and an address to the Citizens of Philadelphia and its vicinity and to the House of Representatives of the United States, adopted.

Vol. I-20 
When, they said, they beheld the attempts made to influence the decisions of their fellow citizens, they would do violence to their own feelings, and be insensible to the interests and honor of the United States, if they did not express their warmest approval of the conduct of those who, in the House of Representatives, had opposed the execution of the treaty with Great Britain. They considered it unequal in its stipulations, derogatory to our national character, injurious to our greatest interests, and as offering insult instead of redress.

Though they lamented the hard cases of such fellow citizens as had suffered from British depredations, and felt their well founded claim to indemnification, they could not consent to surrender national rights to obtain compensation for their losses.

In a quiet way Girard had long been active in politics, and, what was more important, was one of the liberal contributors to the election expenses of the Republican party in the city. Because of his good work, he was, in September, nominated by the Republicans for Select Council; but with all his colleagues on the party ticket was defeated at the election in October.

An account of the April meeting over which he presided as chairman seems to have been sent to Bentalou; but no copy of the letter was entered in the Letter Book. To this Bentalou replied:

"I received your letter of the 18 th inst. (April) which no doubt crossed mine of the 17 th. The public prints had already informed me of the conduct of your Philadelphia merchants. They seem to stand perfectly in line with the rest of the commerce of the United States on the great constitutional question which is agitating the immediate representatives of the People in Congress. It must be acknowledged that there is not a worse republican 
than the business man who, always blinded by his own interests, would sacrifice to his selfishness the most inalienable rights and the most sacred privileges of war. There is no use assisting a class of men who through villainy, ignorance, or want of principle would not only consent to have the United States return to a domestic or foreign yoke, but would even contribute to such a result to the best of their ability. The most active faction as a class would prefer England, and I would be still more uneasy if I were not sure that our rural districts still have enough Republican virtue left to put in check all the sinister designs of the inhabitants of our cities. ***

"The present madness will pass away, and good and true Republicans will again be triumphant. The arrogant tone of our 'merchants and traders' has provoked opposite meetings here and in your city, where I am glad to note that you were made chairman.

"Our two insurance companies have suspended operations in imitation of yours and those of New York, and as there are no private offices here, I find it impossible to insure the schooner Rose."

The Nancy, towards the end of March had sailed, under the command of Captain John Peden, for the Bite of Léogane with a cargo worth $\$ 19,772$ to be delivered to Massac \& Co. of Port-au-Prince. The Nancy was insured for $\$ 3000$, and the cargo for $\$$ I 7,000 . Nothing was heard of her till May when a letter, written in April, by Massac \& Co. arrived from Port-au-Prince.

"The present has for its sole object to tell you of a report brought in by Captain Corry in command of the ship Driver belonging to Mr. S. Vasse of your city. He was told by Captain Hempton who is in command of a three-master from your port, the name of which he could not tell us, and which left the mouth of your river on 
March Igth, that he saw a schooner from Philadelphia wrecked on Turk's Island, the vessel breaking up the moment she struck land. He does not say that it is yours: but he thought that he recognized her. It seems quite probable since your vessel had not reached the Môle on the $23 \mathrm{~d}$ instant, at which time the Driver left with a convoy for this place. The latter encountered the gale which wrecked this schooner and which, he says, was a very violent one."

"I heard a few days ago," was the prompt reply, "that the vessel went ashore on the island of Mogane. Part of the cargo was saved by certain vessels from Bermuda and Providence. The mate who followed the merchandise destined for Providence came here and gave me about 3000 gourdes for my share of the salvage. The captain took the rest of the cargo to Bermuda and has not yet arrived. The wreck of this schooner is the more unfortunate as her cargo was a choice one and well assorted. But one must have patience, expecially when the crew is saved and the property insured."

A protest relative to the loss of the Nancy and her cargo was at once lodged with the Insurance Company of Pennsylvania and at the office of Wharton \& Lewis, who were requested to notify the several underwriters,

"I. That I abandon the said schooner Nancy and her cargo to the said underwriters as far as I am insured.

"2. That Francis Pastorius, late mate of the said schooner Nancy, who arrived yesterday (May 20, 1796) in this city from Nassau in the Island of New Providence has put in my hands three thousand one hundred and forty dollars, fifty-two cents, which sum appears to be the net proceeds of goods saved and carried to that island."

The Liberty in March had reached Bordeaux after a voyage of thirty days from Philadelphia and a quarantine 
of twelve days at St. Martins. "I could not begin to tell you," Hourquebie wrote, "how bad is the market for the sale of the cargo of your vessel. The only kind of business done here is exchange of coin for assignats. This cursed business is in such vogue that everybody is taking part in it, so it often happens that at the opening of the Bourse a Louis is worth 4500 , by two o'clock 6800 to 6900 and sometimes in the evening in the pit of the theatre it falls back to 5000 . This sort of business is sure to cause some heavy failures, and unfortunately it is the only kind of business done here.

"Generally everything is cheap for cash, and to my great grief I am not able to take advantage of this condition. Although I am willing to make a sacrifice on the flour by offering it at 50 livres, and the rice at 20 , I have not been able to sell a single barrel.

"I repeat that since the Revolution there has never been such a bad time for doing business. Not a merchant is in condition or dares undertake a single venture in merchandise. There is talk of a new paper money being put in circulation."

As to the goods brought over by Captain Post, when Hourquebie decided to send the sugar to Hamburg and began to negotiate for freight he was annoyed to be told that he could not get permission to load the goods. "I at once went to the office and the director confirmed the statement that the exportation of sugar, coffee, tobacco, etc. to foregin countries was forbidden from the moment the articles were unloaded unless the captain or consignee made a declaration that the articles were intended for exportation to a foreign country. It appears therefore that Captain Post was not well advised.

"Truly the market has never been in such bad condition. So far I have done nothing at all and have not 
received a single offer for any article. Wine and brandy are selling for a low price. I could get wine to-day for silver at 240 to 320 for the best for exportation and brandy at 250 to 280 per velte. A vessel with French coin would do a big business. I say French coin because stock jobbing has caused the gourde to fall to 4 livres, 16 sous, the quadruple to 76 livres, ro sous and the portugaise to 36 to 37 livres. In any other condition of the market I would have made use of the purses of my friends to send your vessels back to you, but as things are there is no confidence in business. The decree forbidding tribunals to recognize any engagements save those payable in paper money has caused this want of confidence. People are afraid they will be forced (and it has so happened) to receive this paper in payment for obligations contracted in crowns and speculation has caused a depreciation of from 70 to 80 per cent. in this paper."

In yet another respect was Girard affected by this disordered state of the currency. During the summer of I793 he received from San Domingo a draft on a house in Dunkirk for 30,000 livres tournois and sent it for collection to a firm in Bordeaux with instructions to remit in oil, brandy and other goods by the first neutral ship. The collection was made in assignats, but, unable to make the remittance, the firm held the money. In 1794 Girard drew on them for some nine thousand livres, leaving 19,839 livres, 18 sous in their hands when in March 1796 the Legislature issued a new sort of paper money to be exchanged for assignats.

This was the famous Promesse de Mandat Territorial concerning which the Bordeaux firm wrote in April:

"We must inform you of a resolution passed by the two councils of our present legislature, on the 25th and 28th Ventose, last, (March I6th and Igth) in regard to 
the assignats in circulation, which must be exchanged within three months from the date of the resolution for a newly created paper money called 'Mandats Territoriaux.'

"You will find enclosed an extract of the chief articles of this law and we await your orders in regard to the exchange of your paper money." The extracts read:

"Copy of certain articles of a Resolution passed by the Council of Five Hundred and the Elders, Ventose 25 and 26 , Year 4 concerning the issue of $2,400,000,000$ in Mandats Territoriaux.

ART. 2. These mandats will be legal tender for all persons throughout the Republic, and will be received as specie at every treasury both public and private.

ART. 4. The Mandats will be legal tender for mortgages, loans, and private security on all national estates situated within the entire extent of the Republic, so that the holders of Mandats will have the right to come before the Administration in the Department in which are situated the lands they wish to buy, and after the said lands are appraised, they will be given possession of the same on paying in Mandats the appraised value.

ART. 5. Lands shall be appraised according to the method prescribed in the last law governing the sale of national lands; that is to say: they shall be appraised at a value equal to 22 times the rental, for landed property, and 18 times the rental for a house.

ART. 6. Forests larger than 300 arpents, houses and buildings used for government purposes are not included in the national lands.

ART. 7. All paper money now in circulation will be withdrawn at the rate of 30 for $\mathrm{I}$ in the above issue.

ART. 8. All persons holding paper money will have it exchanged for Mandats within three months after the 
passage of the Decree. During that time it will be accepted as legal tender at the rate of 30 for I. After that date it will be received only in exchange for Mandats."

Girard made no reply and in July the firm again wrote:

"After our present Legislature had passed the decree regarding assignats, of which we informed you in our last, two others were passed in succession. One, enacted on the 3 rd Prairial, provides that assignats which have not been exchanged on the 25 Prairial in Department of the Seine, and on the ro Messidor in the other Departments cannot be exchanged after these dates for Mandats, or promises of the same, except at the rate of 100 for $\mathbf{I}$. The other law which was passed, on the 8th Messidor, provides for an extension of time for the exchange of this paper from the Ioth to the 30 th Messidor and at the same time provides that, beginning with the Ist Thermidor, paper money that has not been presented for exchange will be void throughout the Republic and cannot be accepted for payment in any national treasury.

"In order not to expose the paper money belonging to you to the danger of being exchanged at the low rate of IOO for I, we deposited it on the 27th of last month (June) with the Notary Guy of this City, by permission and request by the administrators of our department who, when they learned that the mandats for which the assignats were to be exchanged had not been sent here, advised the holders of assignats as a means of securing the exchange of assignats for mandats at the rate of 30 for I, to deposit them until the 28th of June, with a receiver or notary public. Your money, accordingly, is included in the deposits which are made with the above mentioned notary and amounts to 19838 francs, 18 sous."

P. S. "It is now July zoth. Not till yesterday did we receive from the Notary Guy of this city, with whom 
we had deposited your assignats, the remainder of the promesse de mandats that we were to receive for the assignats on the basis of 30 for 1 , which produced in all $66 \mathrm{r}$ francs, 6s. in promesse de mandats" for which mandats were to be given as soon as received.

The new brig which for months past had been upon the stocks was now named the Sally and in August was launched. When Captain Cochran gave up his seafaring life the old Sally of which he and Girard were joint owners was placed in the hands of Samuel Smith, a ship broker, to sell as best he could. During six months she was advertised daily; but no buyer was found. Weary of delay Girard decided to sell her at auction and December first 1795 wrote Mr. John Connelly, Auctioneer, "Inclosed you have inventory of the brig Sally. I am informed by Captain John Cochran, half owner of that vessel, that she is built with mulberry, locust and red cedar, about five years old and $1531 / 2$ tons burthen, will carry I 400 barrels. She may be seen at Clifford's wharf.

"Please to advertise said brig immediately in two or three of our newspapers to be sold on Saturday next in the evening for approved notes payable at 60,90 and 120 days."

As soon as the new Sally was launched Massac \& Co. were informed that she would be consigned to them. In April they wrote "that since the 4 th of this month Americans have not been permitted to bring dry goods here, and an unusually sharp lookout is kept for the first shipment of goods that arrives so that we expect a great deal of trouble and do not know that we shall be able to bring in the dry-goods shipped on your schooner Nancy." It might however be possible to smuggle. In that case Massac \& Co. would keep some one at Arcahaye, and as soon as they knew the Captain had reached the Môle, his arrival to be made known by a red flag tied to the 
mizzen mast, the agent would wait for him "at the bight either at Courrejeole or Malingre where we have intimate friends. At these plantations the dry goods could be landed during the night and the vessel then go on to Port-au-Prince. The dry goods must not appear on her manifest, so that the Custom House may not know of it. If this plan should fail, the dry goods being placed at the hatchways in trunks, boxes, or bales, which are easily handled they could be transferred, the night the vessel arrives to another boat and thus we shall be masters of the situation by means of certain precautions which we shall not fail to take. Nobody will be surprised to see us with this merchandise as we always have some in our warehouse." ***

"P.S. Our letter was sealed yesterday but to-day, the I6th inst., permission was again granted to Americans to bring in dry goods. This permission has not yet been posted at the Custom House, but three private individuals to-day received permission to unload dry goods they had on board American ships which arrived in our roadstead on the $4^{\text {th }}$ inst."

The permission was soon revoked and before a month passed they wrote saying:

"It appears to be impossible to count on the actions of the English government. A month ago Americans were allowed to import every kind of merchandise. Well, a week ago a decree was issued, forbidding such importation, and in consequence there are now two vessels in the roadway that cannot unload their cargoes. The general is at present at the Môle. We are waiting for him to come back in order to send a petition requesting him to grant at least three months so as to allow time for those vessels which are to come here, under the new permission that was given, to arrive." *** 
Nevertheless, "if you follow the instructions we outlined in our last of the 15 th of last month, and keep the goods ready at the hatchway, and take care not to enter on the certificate, as the Americans may stay 24 hours at Arcahaye, we have notified our friends, Messrs. Janet \& Latour if they see a vessel with a red flag at the mizzen mast to get ready to carry out the plan, because the said vessel could come to anchor in their roadway, if you will take the precaution to give a letter of recommendation to Janet \& Latour, to your captain."

To this Girard replied: "The prohibition to import dry-goods which seems to have been continued in the ports of San Domingo, in possession of the English, prevents me risking any shipments I had intended sending you," and preparations were made to send the Sally to Hamburg.

August Ist, General Forbes issued another order:

"Notice is hereby given. That it shall and may be lawful for the citizens of the United States of America to import into the British ports of San Domingo, in their own vessels the following enumerated articles. ${ }^{* * *}$ No goods or commodities whatever shall be imported or brought from the United States of America into any Port or Ports of San Domingo in possession of the British after this date, except the above, under the penalty of the forfeiture thereof, and also the ship or vessel in which the same shall be brought together with her guns, furniture, ammunition, tackle and apparel." In the enumerated articles were flour, bread, grains of all sorts, rice, tobacco, live stock, poultry, in short food, lumber, and articles needed to repair ship, but no dry goods of any sort.

Nevertheless on the following day. Massac \& Co. wrote: 


\section{THE LIFE AND TIMES OF STEPHEN GIRARD}

"Although Americans are not permitted to bring dry goods, arrangements can be made whereby the chief's permission is obtained, only the cargoes must be large enough to bear this expense which, however, is not very heavy. This for your guidance."

Thus guided Girard decided to send the Sally to Portau-Prince.

"I have now to inform you," he wrote Massac \& Co., "that in consequence of the advice received from you in regard to this matter, I have just decided to dispatch a brig with a fine cargo to your port.

"The vessel I had launched a few days ago, is put together with copper nails and bolts. At first I had intended to send her to Hamburg where I meant to have her copper sheathed, but as I have changed my mind I shall have the job attended to here, and shall send her to you, as I have already told you, about the end of this month (September). Her cargo will be composed of flour, wine in barrels and boxes, osnaburgs, other linens, cheeses, \&c. In short, barring the perils of the sea or other misfortunes, you will receive the finest cargo that has ever left our continent for your port."

The copper sheathing so delayed the Sally that it was not till October 18 th that Captain William Colladay received two letters of instruction. The first bade him go to the port of Léogane and sell the cargo to the best advantage. Failing in this he was to seek the best market, and bring home coffee. "He was not to receive on board any goods, furniture, or specie, as freight," nor "passengers under any pretext whatever." Should the Sally be seized and taken to any. port of San Domingo in possession of the British he was to apply to Massac \& Co. for aid. If taken to Jamaica, to Messrs. Bridgman \& Hall. A second letter informed the Captain that these 
instructions were intended for French cruisers, if he met any, and were not to be regarded. His real instructions bade him sail to Môle Saint Nicholas "and there wait for a safe convoy for Port-au-Prince. At your arrival at Cap Nicholas Môle you will report your vessel as if you had put in there for safety and to await a convoy," and apply to M. Prevost for orders.

While the convoy was escorting the vessel to Portau-Prince Captain Colladay was "to keep as close as possible to the armed vessel." When "near enough to be seen from Port-au-Prince you will hoist a red jack at the fore gallant mast head, and you will come to anchor with your vessel in the out harbor, or the man of wars anchoring ground generally called great harbor," and report to Massac \& Co.

"As American vessels are not permitted to import dry-goods in the British ports of the Island of Hispaniola, I request your particular attention to be careful in reporting your cargo at the Custom House and should you be obliged to enter the same before having seen and communicated with Messrs. Massac \& Co., enter the whole as if it was consigned to you and report the dry goods which you have on board for exportation."

"If in your passage from Port-au-Prince to this port should you meet with French cruisers, tell them that the destination of your present voyage was for Léogane, but having met with a British cruiser who had obliged you to go to the Môle and from there to Port-au-Prince you had been forced to sell your cargo in that port."

Massac \& Co. were told: "By this vessel I consign to you a superb cargo valued at $\$ 47,287.31$ according to the invoice and bill of lading, but as I am told the French Republic has ordered its warships to seize vessels belonging to neutral nations that have not made their flags 
respected, and that go to British ports, I thought it prudent to make it appear as if this cargo was bound for a French port in San Domingo." The return cargo was to consist of 30 creole barrels of fine raw sugar and fine trade coffee. If "trade with your city offers the prospect of a moderate profit, I intend to engage in it with two vessels and shall even be prepared to increase that number on the slightest encouragement."

On the arrival of the Sally at Môle Saint Nicholas her Captain found that M. Prevost had received no orders from Massac \& Co. regarding the cargo. But, said the Captain, "I have received a letter with orders to proceed to l'Arcahaye with the first convoy which is to sail this evening, we shall touch 24 hours at St. Marks and then proceed on our passage. The Men of Wars boats have this morning paid all American Vessels a visit. out of some they took all hands, and I have had the misfortune to lose one of my people, but I am in hopes I shall get him again."

Convoyed by a I6-gun ship, the Sally sailed for Arcahaye, "where she safely landed all the articles. It took a great deal of care and trouble and a great many roundabout procedures to do this." The flour had been sold at 14 gourdes a barrel, the dry-goods were easily disposed of at Arcahaye, and some of the wine at 64 to 74 gourdes. But when the year closed the Sally was still in port. The net proceeds of the voyage amounted to 372,272 livres, 7 sous, I denier.

The Liberty had sailed for Bordeaux on the $25^{\text {th }}$ of September carrying as a passenger the gentleman who was to succeed Monroe as Minister from the United States to the French Republic.

The conduct of Monroe while Minister to France had been far from pleasing to President Washington. Mon- 
roe had reached Paris early in August 1794 to find the people rejoicing over the downfall of the infamous government of Robespierre, and the execution of the tyrant and his associates St. Just, Couthon and Henriot. Though dead, their arbitrary decrees remained in force and the most arbitrary related to foreign commerce. A captain who entered a port of France with a cargo of flour, grain and tobacco was forced to sell it for assignats. The government was the sole purchaser, for all private trade had been suppressed. And when the assignats were paid not a livre could the captain expend for a return cargo till permission to do so was given him. Meanwhile he was fortunate if his ship was not boarded and the crew taken off and thrown into prison.

All these evils Monroe was eager to have cured, and when ten days passed and the Commission of Foreign Relations named no time for his reception he wrote to the President of the Convention and was received the next day. Letters from Captains complaining of losses and hard usage now came pouring in from almost every seaport of France. These Monroe classified as from "those who were injured by the embargo at Bordeaux; those who had claims upon the Republic for supplies rendered to the government at San Domingo; those who had brought in cargoes for sale and were detained by delay of payment, or some other cause; those who had been brought in by the ships of the Republic, in derogation of the treaty of amity and commerce, and were subject to like detention and delay; those who had been taken at sea, or elsewhere, and were confined in derogation of the treaty of amity and commerce or the rights of citizenship in the United States."

Against all these injuries Monroe protested mildly. "When an American vessel arrives at any port in France," 
he wrote the Committee of Public Safety, "it is immediately in the hands of the Government. The captain or supercargo cannot sell the cargo to any other person, nor can he get more for it than the public agent will give, nor sell elsewhere without permission $* * *$ A regulation of this kind, in its fullest extent, must prove very injurious to both countries and especially to France. Trade cannot exist under it." You will observe, he continued, that "I do not complain that the public are the sole purchasers and regulate, at pleasure, what shall be exported, provided the vendors are paid for their cargoes in some commodity or specie, at their option;" what he wished was, "that the ports of France may be opened freely to the enterprise of my countrymen." The Bordeaux embargo and the claims on the Government of San Domingo were matters of account which he hoped would be "immediately adjusted and paid."

As France at that time was seeking from us a loan of money to be used for war purposes the Committees of Public Safety, Finance and Supplies acted promptly and on the 25th Bumaire (November 15, 1794) ordered that the vessels of neutral Powers might enter and leave French ports when they pleased; that captains should not be obliged to sell cargoes against their will; that when cargoes were sold to the government they should be paid for according to the bargains made; that claims for losses covered by the Bordeaux embargo should be liquidated without delay, and that accounts for supplies furnished San Domingo should be received by the marine committee and measures taken to secure prompt justice to the claimants.

Scarcely had these pledges been given when English newspapers reached Paris with such accounts of the work of Mr. Jay as greatly alarmed the rulers of France, for one report had it that the United States had entered 
into an offensive and defensive alliance with Great Britain. A request for information was at once made on Monroe, who wrote to Jay for a copy of the treaty, for "nothing will satisfy this Government but a copy of the instrument itself, which, as our ally, it thinks it self entitled to." Jay would not send a copy because the treaty had not been ratified, because certain parts of it might give rise to further negotiations, because if finally ratified it might be very different from what it then was; and because such a proceeding was wholly without precedent. Nevertheless Mr. Jay would send Colonel Turnbull, who had copied the treaty, to communicate its contents in the strictest confidence. To this Monroe would not consent and complained bitterly of Jay in letters to the Secretary of State.

In mid-August copies of Philadelphia newspapers of July third containing the treaty in full reached Paris; late in November the National Convention gave place to the Directory, and February, I796, Monroe wrote that the minister of foreign affairs announced that the new government considered the alliance between France and the United States as ended the moment Jay's treaty was ratified and would send an envoy extraordinary to represent that view to our government.

De La Croix complained that we had failed to execute our old treaties with France by taking cognizance of prizes brought in by French privateers, by admitting to our ports English vessels together with their prizes; by failing to give French Consuls exclusive jurisdiction in controversies between French citizens; by preventing their arresting French deserters; by seizing the captains of a corvette for an act done at sea; and by making with England a treaty which put on the list of contraband of war provisions, not merely when destined for a blockaded port, but in all cases thereby acknowledging the pre-

Vol. I-21 321 
tensions of England to place at pleasure and by proclamation not only the French islands but France herself in a state of virtual blockade.

Monroe did what he could to answer these complaints: but without avail. The Directory held firmly and persistently to their opinion and in September, 1796, Monroe was recalled and Pinckney appointed minister plenipotentiary in his stead.

In October De La Croix notified Monroe that the Executive Directory charged him to announce "the suspension of all the functions which it has prescribed to the minister plenipotentiary of the French Republic near the United States," and to communicate an arrêt decreeing that all French ships "armed for war will treat the United States as these suffer the English to treat them." Concerning General Pinckney, Girard wrote to Captain Ridg: "I request as a particular favor that during your passage to France you will pay the greatest attention and civilities to Gen ${ }^{1}$. Pinckney his Lady and family who are going passengers on board your vessel. That gentleman is appointed minister for the United States of America to France. Immediately after his arrival at Bordeaux I request that you will advise $M$. J. Hourquebie of the same and desire him to render our said minister all the services which may be in his power either by procuring him lodgings \&c. or otherwise."

The cargo consisting of James River tobacco, Portau-Prince sugar, coffee and Gonaives cotton was valued at $\$ 33,147.94$ and consigned to Hourquebie. From Cape Henlopen the Captain wrote that the wind was fair and he hoped it might "continue in the same Pinte of the compas for four weeks that we ma have a shoter passage on a counte of the Ginarl and his family for the are very sosabel and kind to all hands on Borde." 


\section{CHAPTER VIII}

THE LIBERTY CAPTURED; THE MODEST WRECKED

When the year 1797 opened the Sally was at Port-auPrince, the Liberty at Bordeaux, the Voltaire and Good Friends at sea. The Good Friends, from Hamburg, after a voyage of twelve weeks, eight of which were spent "beating on our coast," reached the mouth of the Delaware, found the river full of ice, sailed for New York and did not arrive at her home port till February, just before the Sally returned from Port-au-Prince with sugar and coffee costing 450,581 livres. She was to return, Girard wrote his agents, Massac \& Co. with a cargo worth 50,000 gourdes, and to guard against mishaps after reaching San Domingo, Bentalou was requested to obtain letters of introduction to Toussaint Louverture.

"A few days since I had the pleasure of seeing your friend Thibeaux, but his stay in our city was so short I lost the pleasure of having him dine with me and telling him about a venture I have undertaken for San Domingo. As this venture is a very important one and the Republicans might possibly molest my captain, or seize all, or part, of my cargo, which will consist of wine, flour and dry goods, I will ask you, my dear Bentalou, to get from our good friend Thibeaux a letter to General Toussaint Louverture the officer in command at Gonaives where my vessel will go directly from here, because produce is more abundant there than elsewhere. Ask him also for a letter of recommendation to Citizen Sonthonax for my captain, in case he should go to Le Cap. The captain's name is William Colladay, Jr. and the brig's name is the Sally." 
Bentalou at once replied, "I have made known your intentions to Thibeaux without loss of time, and you will receive enclosed the result of his work."

The letter to Toussaint is headed, "Pageot, général de Brigade a Toussaint Louverture, général de division, comd "en chef le départment de l'ouest," and reads:

"I have been on the continent for nearly two months and am impatiently waiting for a small vessel belonging to the Republic to sail for France. I expect to embark in her.

"During my stay in this country I have sought to interest the good patriotic merchants to come to the aid of our brave defenders by sending them provisions. This will be handed you by Captain Colladay commanding the brig Sally. This boat is destined for Gonaives and belongs to a good French citizen, good patriot named Girard, merchant in Philadelphia, owner of one of the best commercial houses in the city and well able to come to the aid of San Domingo. He has asked me for a letter of introduction to you. I have given it with great pleasure. I beg you, general, to give every satisfaction possible to this merchant, to hasten the return of his ship that it may continue to go to your relief."

With this letter was another from Pageot to the citizen commissioner who called himself, "brigadier general to the commission sent by the government of France to San Domingo." In it General Pageot again described the Sally as owned by "The citizen Girard one of the richest merchants in the city (a good patriot and friend of the Republic). It is important therefore citizen commissioners that this merchant should be satisfied with this venture of his in order to encourage him to continue his shipments as he is better able than anyone else to help you. His is one of the first commercial houses here and he enjoys 
a very great credit: moreover he is naturally disposed to help our brave defenders."

Francois-Dominique Toussaint Louverture was a fullblooded negro born not far from Cap Français. After the uprising of the blacks in the summer of 1791 Toussaint joined one of the bands, rose to a place of importance and when war opened between Spain and the French

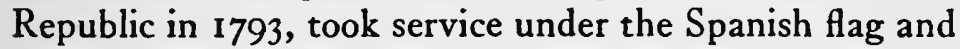
in the Spring of 1794 was in command of some several thousand well armed, well trained troops. Alarmed at the invasion of San Domingo by the British, convinced that under their rule slavery, which had just been abolished, would surely be restored, he determined to quit the service of Spain, and in May 1794, his negro troops, by his order, massacred the Spaniards under his command and went over with him to Laveaux, who held the country around Port-de-Paix. Thereupon the Spanish forces, astonished at his act, evacuated many of the posts they held in the North.

War upon the British and the Spaniards by the negroes now began in earnest and before the end of 1794 Toussaint had driven out the Spaniards and Rigaud had captured Léogane, and by 1796 was the recognized leader of the black population. The Directoire then governed France, Spain had ceded her part of the Island to France and in hope of restoring French authority the Directoire dispatched thither five commissioners and three thousand men commanded by Rochambeau.

The chairman of the Commission was Sonthonax, who had been declared not guilty of the charges made against him. With him were Roume, Leblanc, Raymond, a mulatto, and Giraud. Sonthonax began by allying himself closely with Toussaint and, eager to make himself ruler of San Domingo, proceeded to get rid of his col- 
leagues one by one. Leblanc soon died, it was said of poison. Girard was forced to leave for France and was in Baltimore when Bentalou obtained the letters Girard desired. From Raymond, Sonthonax had nothing to fear. Roume had gone to Spanish San Domingo to prepare for the surrender of that part of the island to France according to the Peace of Bâle. Laveaux was elected deputy from San Domingo, and Sonthonax seemed to be supreme. But Toussaint now turned on him, had him elected a deputy and, August 20, 1797, appeared at Cap Français at the head of an army, urged Sonthonax to set off for Paris at once and the next day he departed.

Captain Colladay having refused to take command of the Sally his place was filled by Captain John Dorson. $\mathrm{He}$ also had two sets of instructions, two invoices, two bills of lading. One set, "for the sole benefit of any French cruisers you may meet on your voyage," bade him go to Gonaives, deliver in person the letters for General Toussaint Louverture and John Carrere père, and hand those for Sonthonax and the American Consul, to Toussaint. The second set of instructions bade him pay no attention to the first, but to proceed to the Môle, wait for a convoy to Port-au-Prince, and when in sight of it hoist a red flag on the fore gallant mast, find safe anchorage and report to Massac \& Co. One invoice and one bill of lading contained the articles permitted to be landed at British ports; on the other invoice and bill of lading were the brandy and dry-goods.

Two weeks after the Sally sailed the Liberty came in from Bordeaux with a cargo worth 259,036 livres. Girard would gladly have sent her back, to the port whence she came, but the long pending rupture with France had occurred, diplomatic relations were broken, and war soon followed. 
After the recall of Monroe, General Pinckney was appointed Minister to France. He reached Paris early in December 1796 but, when Monroe asked on what day De La Croix would receive the new minister he was told the Directory "will no longer recognize nor receive a minister plenipotentiary from the United States, until after a reparation of the grievances demanded of the American Government, and which the French Republic had a right to expect."

Monroe sent the note to Pinckney, who reminded De La Croix that Mr. Pinckney, not Mr. Monroe, was minister from the United States and asked, as no cards of hospitality had been received, if it were the wish of the Directory that the American Minister quit the soil of France. The chief Secretary of Foreign Affairs replied that The Executive Directory knew of no minister plenipotentiary since citizen Monroe delivered his letter of recall; that De La Croix could hold no official communication with Mr. Pinckney, who no doubt was aware of the law which forbade a foreigner to stay more than thirty days on the soil of France without a letter of hospitality. Pinckney asked if he should leave or stay in Paris till he heard from home. The Secretary did not know, but would inquire, and when he came again replied that Pinckney must leave not only Paris, but France. This he refused to do; but the day after the arrival of news of Napoleon's victories in Italy Pinckney received written orders to go, obeyed, crossed the border, and went to Amsterdam.

It was March 1797 when his report came to the Department of State. Adams by that time had been inaugurated President, and, Congress not being in session, he at once called a special session to begin on the fifteenth of May.

In this state of affairs Girard decided not to send the Liberty back to Bordeaux. "I am extremely sorry to 
observe," Hourquebie was told, "that there exists a kind of misunderstanding between the French Republic and our government though $\mathrm{I}$ am assured that all matters in variance between them will be shortly settled to the satisfaction of both parties. Nevertheless I will postpone sending you the brig Liberty until I see this business in a fair way of being settled in an amicable manner.

"Mr. Adams our new President has requested the Senate and Congress to meet on the $15^{\text {th }}$ of May next. I shall embrace the first opportunity to inform you of the result of this extraordinary sitting."

Captain Ridg was now discharged, Captain Thomas Lillibridge put in command, Mr. Alexander Dobignie made supercargo, and in May, 1797, the Liberty sailed for Havana with a cargo stated in the invoice and bill of lading to be worth $\$ 55,210.26$. "Though it is understood by the Spanish passport which I now deliver to you," Mr. Dobignie was informed, "that the flour which I have shipped on board the brig Liberty is to be exported from Havana, to a foreign port, I flatter myself that by your perseverance and exertion the government of Havana will permit the landing there of the said flour. In the contrary case I request that you will manage the landing, disposal and destination of said flour as well as you can.* *

"As my principal motive in sending my brig Liberty to the Havana is to open a new branch of commerce for my vessel, I beg that you will do your endeavor to obtain from the government of that place a permission to introduce in that city flour, or other articles, which will appear to you of a quick and advantageous sale. Should you succeed you may rest assured that no exertion shall be wanted on my part to accomplish your promise to the person who granted you said permission."

On the third day at sea the Liberty fell in with the 328 
British frigate La Raison, Captain Beresford, about seven o'clock in the evening. She fired a gun: but Captain Lillibridge attempted to escape. The frigate gave chase and at eleven o'clock the next morning the brig was brought to, boarded, searched, and ordered to Halifax. Mr. Dobignie was sent on board the frigate, which soon after the capture of the Liberty brought to a schooner bound for New York, and ordered her master to come aboard. When about to be released to continue his voyage the Captain was asked by Dobignie to report the capture when he reached New York. He did so, and in the New York Gazette of May I8th Girard read of the capture of his brig.

The Insurance Company of Pennsylvania, and the Insurance Company of North America, each of which had insured the Liberty for $\$ 6000$ and the cargo for $\$$ I 5 ,$\infty$, were ptomptly notified and invited to share with Girard in the cost of seeking her recovery. Timothy Pickering, Secretary of State, was then appealed to for aid.

"The brig Liberty," he was informed, "was built at Kensington, Northern Liberties, County of Philadelphia, in the year 1795 by Mr. Isaac White, for my account and under my directions. Since that period that vessel has continued and is still my property as it appears by the copy of her register A."

The Liberty was sent to Havana because he was desirous to oblige his "particular friend Mr. A. Dobignie, a gentleman who is a native of France and a citizen of the United States of America, and having also a large quantity of dry goods on hand suitable for the Spanish market, $I$ advised that friend to try to obtain from the Spanish minister a permission to introduce a cargo of flour and other articles to the Havana. I added also that in case I 
should succeed I would load my brig Liberty and give him the consignment of her cargo. Some time after he informed me that, through the channel of one of his friends, he had obtained the promise of a permission for two thousand barrels of flour under certain pecuniary conditions. In consequence of that assurance I went on preparing the brig Liberty and procuring her cargo; but about the 22 ult $^{\circ}$., Mr. Dobignie participated me the disagreeable intelligence that the Spanish minister had resolved to grant no permission for the exportation of flour to the Havana. Having at that time the greatest part of my flour purchased I requested him to represent to his friend, or to the Spanish minister, my unpleasant situation and to insist on the permission which I believe he did, and was still refused. Having no alternative, and as my principal object was to procure the admission of my brig Liberty into the port of the Havana, relying that the activity etc. of my supercargo should enable him to negotiate etc. the landing of the whole cargo, I proposed that a permission should be given for my brig Liberty to go to the Havana with flour, and other articles permitted, with the express understanding that the said flour should be exported from the Havana to some foreign port. After some difficulty etc. the permission was granted."

Copies of the manifest, the letter of instruction to Dobignie, the bill of lading with an affidavit that the cargo belonged to Girard, and certificates setting forth that he had resided in America since 1774, and was a citizen of the United States, and certificates of insurance were enclosed in the letter, and the Secretary requested to take such steps as would insure speedy justice.

The insurance companies having accepted the proposal of Girard, Mr. John Lewis was chosen to go to Halifax with a mass of documents to prove that ship and 
cargo belonged to a citizen of the United States. A few days later the Secretary of State made this reply: "Colonel Pickering has the pleasure to inclose to Mr. Girard a letter from Mr. Liston to the Governor of Nova Scotia relative to Mr. Girard's brige Liberty supposed to be carried thither."

Mr. Robert Liston was minister from Great Britain, and in his letter to Sir John Wentworth, Lieutenant Governor of Nova Scotia, said: "Colonel Pickering the American Secretary of State has applied to me in favour of Mr. Stephen Girard, proprietor of the Ship Liberty, commanded by Mr. Thomas Lillibridge, which is said to have been intercepted on her way to the Havana by His Majesty's Frigate La Raison, and carried into Halifax.

"As I am desirous to do everything in my power that may be agreeable to the Secretary of State, and not less anxious to give my support to any cause which appears to have justice on its side, I cannot avoid taking the Liberty of recommending the bearer, Mr. Lewis, the agent of Mr. Girard, to your countenance and protection.

"The idea entertained here is that the capture has been made on a supposition that the owner was a Frenchman. Now Mr. Girard, though in fact a native of France, has resided in this Country (as I am assured by Gentlemen of the highest Credit) ever since the year I774, and must certainly be considered a citizen of the United States.

"It appears therefore only to remain that he should prove the Cargo to be neutral property of which he says he is able to produce sufficient evidence.

"This question must be decided in a Court of justice, and I can only ask of you to give Mr. Lewis, through 


\section{THE LIFE AND TIMES OF STEPHEN GIRARD}

some of the gentlemen who are attached to you, such advice and assistance as may be consistent with propriety and may tend to insure to the cause a full hearing and an impartial Trial."

Thus provided with documents and letters Mr. Lewis went to New York, found a brig bound direct to Halifax, persuaded the Captain to take him as passenger, reached Halifax on June 13th, and with Captain Lillibridge and M. Dobignie called on the Governor, and wrote Girard:

"From the governor and Mr. Forsyth (of William Forsyth \& Co. to whom Girard had a letter introducing Mr. Lewis) I have received attention and assurances of their assistance in pursuit of justice in the case of the Brig Liberty and her cargo which I find was Libelled on the 7th Instant. We have therefore retained Messrs. Stewart \& Brenton to put in claim and conduct the cause. These gentlemen, as well as every person who knows the circumstances of the case, are clearly of opinion that the decision of the court must be favorable to us and that the vessel and her cargo will be acquitted."

Nevertheless Mr. Lewis feared the captors would appeal. "In order to combat this I have reserved the Interest and interference of the Governor who has promised me that he will use his influence not only with Captain Beresford, but with the admiralty, and if necessary with the Prince, to prevent any appeal on the part of the captors from the decision of this court."

June 27th the Judge of the Court of Vice Admiralty sat to hear the cause. "The principal ground taken in behalf of the Captors is," wrote Mr. Lewis, "that you having consigned your property to the management of Mr. Dobignie (who they contend is a Frenchman) that property ceases to be yours and immediately becomes his own and is therefore liable to confiscation; that his 
certificate of citizenship (if real) does not extend beyond the United States, and he being overtaken by His Majesty's Cruisers in possession of such property it becomes lawful prize."

"The suit about your brig," wrote Mr. Dobignie, "began yesterday (June 27th) and the opposing council presented certain astute grounds altogether outside of the question or issue. The two points on which they depended to prove the capture legal are, that I am a Frenchman by birth and that my naturalization is null and void, because Englishmen cannot change their allegiance, and therefore having entrusted an enemy with your interests to go to an enemy port, you have broken the laws of neutrality.

"Their second argument is, that, as you placed your brig and her cargo entirely in my hands to take them wherever I wished, there is no doubt that I am an-interested party if I am not actually the sole owner.

"Such in two words are the arguments of our opposing attorneys, which are both captious and groundless. They talked for three hours to establish such senseless and ridiculous grounds. It would have been a good thing, as one of our attorneys remarked, if this matter had never been brought before this court, and all there is left to be done he said, is to convict Mr. D of being a criminal and send him to the prison ship. This judicious remark had an evident effect on the judge who adjourned the case to the $29^{\text {th }}$ instant, and could not help saying that I was out of the question. Mr. D is out of the question $* * * *$

"Today, the $29^{\text {th }}$, having just left the court, I give myself to the task of telling you about your brig.

"Your attorney replied by quoting certain documents which produced their effect as soon as they were exhibited 
and the judge appeared to be convinced of the justice of the course. The attorney general then spoke, and his argument tended to make me out a Frenchman, and that, as such, you had violated the laws of neutrality; and that having confided your property to an enemy and destined it for an enemy port, the cargo and vessel were subject to condemnation and ought to be condemned. The judge listened very attentively and appeared to be impressed by this false principle. Owing to his great age it is to be feared he will not consider the documents as carefully as he ought. If he does so I have no doubt his judgment will be favorable. But if he should allow himself to be swayed by there ingenious arguments!"

"On Saturday the Ist Inst," wrote Mr. Lewis, "we obtained a Decree in the Court of V. Admiralty here restoring us the Vessel and Cargo, but as there appeared to the Judge sufficient ground for sending her for Adjudication he condemned us to pay all the costs of the Trial."

The decision handed down by the Judge was as follows:

Nova Scotia Court of Vice Admiralty.
In the name of God, Amen.

We Richard Bulkeley Esq. Judge and Commissary of His Majestys Court of Vice Admiralty for the Province of Nova Scotia and the maritime parts thereunto belonging-

Having maturely considered the merits of a certain Libel exhibited to this Court by Sampson Salter Blowers Esquire, His Majestys Attorney Gen ${ }^{1}$ and Advocate in said court, who prosecutes for and in behalf as well of His Majesty as for John P. Berresford Esquire, Captain and Commander of His Majestys Ship of War Le Raison, and the other Officers and the Crew of the same Ship of War, wherein the said Attorney Gen ${ }^{1}$ among other matters 
alledges and sets forth-that the said John P. Berresford being cruising in and with His Majesty's Ship of War, Le Raison on the High Seas, in or about the Latitude of thirty-four Degrees North and Longitude seventy-two Degrees West on the Sixteenth day of May in the same thirty-seventh year of His Majestys Reign, he fell in with and seized as Prize a certain Brigantine called the Liberty of the Burthen of Two Hundred and fifty Nine Tons, then under the command of Thomas Lillibridge as the Master thereof, and being Ladened with Flour, Pork, Lard and other Merchandize, and hath brought the same Brigantine Liberty - and Cargo into the Port of Halifax aforesaid for adjudication, and further Stating that the said Brigantine Liberty and all and singular the Goods and Merchandises her Cargo on board at the time of the Seizure aforesaid belonged to France or Spain, or to some person or persons being Subjects of France or Spain, or Inhabiting within some of the Territories of France or Spain, and all its Papers, Books and Writings found on board said Vessel at the time of Capture having been Lodged in the Registry of this Court, and such of them as either of the parties chose to use as exhibits in this cause having been read and fully considered together with the examinations taken in preparatory under the Standing Interrogatories, and also the Claims of the said Brigantine Liberty and her Cargo, and every other matter and thing requisite and Necessary for a fair and impartial hearing and trial of the Provinces having been fully attended to-We do pronounce this our definitive Sentence and Decree thereon as follows. We do adjudge and Decree the said Brigantine Liberty-her Boats, Stores, Tackle, Apparell and Furniture and also the whole of her Cargo on Board to be Restored to the Claimant, Nevertheless as the Court is fully Satisfied, that there was a 
sufficient and probable Cause for the Siezure and Detention of said Brigantine Liberty and her Cargo, We do adjudge and Decree that the Claimants do pay all and singular the Costs incurred in the Provinces to be taxed and allowed by us.

Given under our hand and the Seal of said Court at Halifax the first of July I797, and in the $37^{\text {th }}$ year of His Majestys Reign.

R. Bulkeley."

The captors having failed to take an appeal the Judge on the day following issued this order:

"The Brig. Liberty and Cargo, Thomas Lillibridge Master having undergone adjudication in this Court and Decreed to be Restored to the Claimants, and the Captors having declined to Appeal from our Decree in the premises We do hereby Order and Direct that said Brigantine Liberty her Boats, Stores, Tackle Apparell and Furniture together with her Cargo on Board be forthwith Restored and Delivered up to the Claimant."

Governor Thomas Wentworth then gave this safe conduct :

"Permit the Brig Liberty, Thomas Lillibridge master, discharged, upon trial, by the Court of Vice Admiralty here, as per Certificate, navigated with twelve Persons in the whole; to depart this Harbour, and proceed to sea on her lawful business.

Halifax $6^{\text {th }}$ July 1797."

T. Wentworth

The certificate alluded to was issued by the Court and reads:

"We do allow and permit the Brigantine LibertyRobert Lillibridge Master to proceed from this Port with his present Cargo on Board free from Molestation or Interruption from any of His Majestys Subjects." 
The lawyers' fees were ten guineas, and the costs and other expenses $\$ 1483.33$. These paid, the Captain made ready for sea, shipped a new crew, entered a protest because some articles were stolen by the captor's crew, and, after waiting six days for a fair wind left Halifax for Havana.

Where to send the Good Friends, after her return in February, Girard was unable to decide. Amsterdam was finally chosen and when she set sail for that port, in March, Mr. William Vans Murray, Minister from the United States to Holland, was a passenger. To the consignee Girard wrote "should it appear that the disposition of the French government is still favorable to the Americans and that the Good Friends may proceed to a French port in Europe without running any risk of being captured or detained" she was to go on to Bordeaux: "If in the contrary case the prospect of a free intercourse between France and America should appear gloomy (which I hope will not be the case)," she was to return to Philadelphia. "I particularly request your civilities and attention to our Minister (passenger on board the ship Good Friends) Mr. Vans Murray."

At the Trexel there was a long delay because, the Consignee wrote, "The lighters used for transporting, from the Trexel to Amsterdam, part of the cargoes of large vessels, as large vessels cannot come here with their full cargoes, have been requisitioned by our government and this effect of the present war, like so many others, falls chiefly on the merchants."

Messrs. Levie Salomons \& Sons reported that on the receipt of Girard's letter they gave "the necessary orders to the Dutch consul at the Helder how to proceed on the arrival of the Good Friends with Mr. Murray at the Trexel. Accordingly he forwarded us an Express and we went

Vol. I-22 337 


\section{THE LIFE AND TIMES OF STEPHEN GIRARD}

with our Equipage accompanied by the American Consul as far as nearly to the Helder to congratulate him on his safe arrival and accompany him with his lady to Amsterdam."

On his arrival at the Hague Mr. Vans Murray wrote Girard, June 29, I797:

"Messrs. Salomons your worthy friends to whom you so unexpectedly made me known by a private letter have duly honored your bill \& have especially discharged the Bill of Kindness \& Hospitality which you so obligingly drew on them in my favour as an acquaintance. They have on all occasions manifested how truly they respect you by their politeness to me.

"As you must have perceived, we had a long passage \& a tempestous one,- - but the ship was good and the crew excellent \& the Captain as good a seaman \& as vigilant \& sober a commander as I ever knew. It is but justice to say that he is completely a skillful \& trustworthy man. The directory have recalled Bonaparte \& divided his army. The Two new thirds of the two councils in France are becoming more favorable to the United States. A motion by, I think, M. Pastoret has been referred to a Commission the object of which is that the Directory lay before the legislature the measures it has taken respecting the U. S., \& their actual mutual relations at this moment. Sincerely do I hope that they will do us justice so that the two friends may again shake hands."

At Port-au-Prince the Sally was long delayed for want of a convoy: but at last, on the evening of May I 8th in company with several ships she set sail convoyed outside the channel by the armed brig Jason. The price for this service was 200 gourdes per vessel. "But," wrote Massac \& Co. "as we know the Captain and the money 
is to go to his owners, we decided to give him an additional 10 gourdes as a particular gratification for the greater security of your vessel, which he promised us to watch over with the greatest care."

"The general states he has sent to the continent a proclamation forbidding Americans to import dry-goods into this country. If you know of it and still intend to send dry-goods your vessel should be sufficiently armed to defend herself against the barges so as to unload her cargo, without running any risk, at the same place as on her last voyage or elsewhere if Messrs. Janet \& Latour, or Charles de Talmours to whom you may give your captain letters of introduction, indicate some other place." Flour was then but I 2 gourdes a barrel, while coffee had risen to 30 sous and sugar to 75 to 80 livres.

Girard did not intend to send her back and wrote Massac \& Co., her next voyage would be to Europe. "The risks to which our flag is exposed in navigating your waters, and the insults etc. we received daily from the pirates, (a more suitable term than that of armed vessels) lead me to give up for a time my shipments to the islands. I am sorry to be forced to do this, as I have at the present moment on the stocks a brig, fastened with copper nails and bolts and copper sheathed, which will be launched within a month. Besides I have in my. warehouses 350 barrels of old and new claret and white wine in tierces," and "a superb assortment of dry goods and provisions. I note that, according to the invoice, the remittance you made me by my vessel amounts to 427,334 livres, I7 sous, 6 deniers."

Hourquebie, at Bordeaux, was now informed that the Sally has "arrived with a superb cargo, and, as I wish to deposit some funds in Europe in order to pay back any advances you make in despatching my vessel the 
Good Friends, I shall load this vessel entirely for my own account with sugar and coffee and send her either to Hamburg or Amsterdam. My correspondents in either of these places will advise you of her arrival."

"Wine and brandy are selling slowly, especially the former which will soon be without demand, as the English have, according to their custom, taken the liberty to declare all ports of the French colonies in a state of blockade while, on the other hand, the French are seizing American vessels bound for English ports. You can therefore imagine in what a critical situation we are."

Hamburg was chosen and the Sally commanded by Captain John Dorson set sail with sugar and coffee consigned to Berenberg, Gossler \& Co. The cargo, valued at $\$ 78,74 \mathrm{I}$, was insured for $\$ 40,000$, and the Sally, worth $\$ 16,000$, for $\$ 10,000$. Messrs. Berenberg, Gossler \& Co. were to give Hourquebie credit for 60,000 Marks Banco.

"A few thousandweight of coffee which could not go in the brig Sally" valued at $\$ 6166.10$ were shipped on the brig Aeriel, consigned to Messrs. Noonagle, Schwartz \& Roques, Hamburg, who were instructed to spend the net proceeds in dry goods to be sent back by the Sally.

Both shipments arrived safely early in August, and late in September 1917 the Sally sailed for home.

About the same time Girard received a letter from Captain Smith announcing the arrival of the Good Friends at Chester. There he was stopped, for yellow fever was raging in Philadelphia, the city was under strict quarantine, and the Custom House had been moved to Chester. Early in August, 1797, some people, living in the neighborhood of Penn and Pine Streets, died of the fever; and their deaths was followed by wild alarm. Some declared the armed ship Hinde, just from Môle Saint Nicholas, had brought the fever; others attributed it to the crew 
of the Arethusa; but all agreed in denouncing the Health Inspectors for their gross and criminal carelessness in passing the ships. The Resident Physician of the Port hastened to defend the Inspectors, assured the public that the attempt to trace the fever to certain ships from the West Indies was most unjust, as every vessel from foreign ports had been carefully examined, and pledged his word that no one, ill of the yellow fever, had passed through his hands during the summer. The Board of Health assured the citizens that the fever at Penn and Pine Streets was so limited in extent that they were sure if the public would take proper precautions the malady could easily be checked. These precautions were, the removal of every patient to some place distant from the city: the removal of occupants of houses adjacent and opposite the infected dwelling: hanging yellow flag from the houses occupied by patients, or from which sick persons had been removed, and the preparation of the City Hospital for the receipt of the afflicted.

Governor Mifflin, in alarm, called on the College of Physicians for advice; but that body was so slow in giving it that he lost patience and issued a proclamation. Whereas, it ran, Inspectors of the Board of Health had reported to him that infectious diseases existed in the West Indian islands, that there were reasons to apprehend danger from intercourse with New Orleans, and the British, Dutch, French and Spanish ports in the Main, therefore, vessels from any of these ports or islands must stop in the middle of the Delaware, opposite the Health Office on State Island, and remain ten days in quarantine.

A circular letter addressed by the Board of Health to the physicians in the city asking how many cases of yellow fever they had attended brought replies which showed that eleven knew of fourteen cases. Governor 


\section{THE LIFE AND TIMES OF STEPHEN GIRARD}

John Jay of New York thereupon laid a quarantine on vessels that came from Philadelphia, and the Governor of New Jersey ordered the arrest of any person who entered that State from a quarantined vessel with the intent of going into Philadelphia.

When, at last, the College of Physicians answered the request of the Governor for advice, it recommended temperance, caution as to clothing, fatigue of body, and exposure to the sun and night air, and that the streets be sprinkled and the gutters well washed, and that no intercourse be allowed with any part of the city where the fever appeared.

Daily reports from the Board of Health announced that on August 2ist there were ten cases south of Pine Street, most of them in Penn Street; that on August 22nd two new cases were discovered, and on the $23 \mathrm{~d}$, fifteen. There were then in hospital at the Wigwam twenty-seven cases. It was recommended, therefore, that the sick, if willing, and all dwellers in the house of the sick, be removed: that if the sick were not removed, occupants of adjacent houses should go: and that on the recovery of the afflicted their beds, clothes, and the furniture of their rooms be fumigated, for two days, by placing on a pan alternate layers of brimstone and charcoal and igniting the mass by setting fire to bits of bark placed on top. All this should be done by Africans who should also be employed to bury the dead. For such as were forced to leave their homes and were too poor to seek a refuge in the country, thirty tents had been put up on the vacant lots between Broad Street and the Schuylkill River along the road leading to the middle Ferry. The Board now turned to Girard and August 26 he received this letter from the Mayor:

"I have the honor to inform you that you are appointed one of the Inspectors of the Health Office of the City and Board of Philadelphia. 
"Your entering immediately on the Duties of your appointment will be usefull and acceptable to the Board."

The post was accepted and, with Lownes and Connelly, who had rendered good service during the dreadful days of 1793 , Girard was put in charge of the City Hospital. Henceforth all bulletins from the Hospital were signed by them.

Men who, in the worst days of 1793 and 1796 , never thought of leaving the city now closed their shops and houses and fled. A peculiar malevolence was thought to attend the disease. One in five of the sick, it was believed, died. At such a time men of sense should have done all in their power to allay excitement. But the Governor in a proclamation took pains to increase it. Yellow fever he held was contagious. Therefore all intercourse must be cut off with the wharves and houses in the infected district, bounded by South, Front, Spruce Streets and the Delaware River. Streets must be barricaded, and yellow flags hung from the houses of the sick. To climb over the barricades, to enter a house from which hung a yellow flag, to talk to a fever-stricken person were made acts punishable with a fine of three hundred dollars. Whoever refused to admit an inspector to a house, whoever hindered him in putting up a flag, whoever pulled down a flag, was to be taken to the hospital on State island and there quarantined for thirty days. One-half the fines were to go to informers.

Against the proclamation vigorous protests were made in letters to the Governor, and to the press. Matched it cannot be, said Peter Porcupine, outside of Republican France. What! enter my house by force and drag thence my wife or my child for no other offense than that of being sick? And if $I$ insist on defending them fine me or transport me to State Island? Pray, good Mr. Thomas Mifflin, 
tell us in what tyranny consists. Many of us begin to fear it is fast growing up in America. But no one spoke with more authority than Dr. Jean Deveze, who had treated the disease in Jamaica and had, with Girard and Peter Helm, nursed the sick at Bush Hill in I793. He now assured the Governor that everything likely to cause consternation, or fear, should be carefully avoided, that the publication of sick lists and death lists in the newspapers was most unwise, and the display of yellow flags, the barricading of streets, the carrying away of the sick by force most pernicious. Such things spread terror. At Marseilles, when the fever raged fiercely, no one ever thought of acts so barbarous. The inspectors of health protested that no sick had been removed unless the attending physician thought it necessary. In no case had force been used. One fence, and but one, had been put up in Penn Street where the fever raged with malignancy. As for the hospital, it was in fine order. The sick were well cared for and their families given accommodation in tents near by.

As to what should be done to check the fever the doctors disagreed and two factions arose. One, headed by Dr. William Currie held it had been imported and was contagious. The other, led by Dr. Benjamin Rush, laid the fever to dirty streets and loathsome alleys and urged the use of mercurial purges and copious letting of blood.

While the doctors wrangled the people died, and the city was almost deserted. Chester and Wilmington were full of refugees. No stage coaches came into or went out of town. Justice ceased to be administered in the Courts. Even the Federal Government took flight. " The President was at Braintree; the State Department was at Trenton; the War Department at the Falls of Schuylkill; the Attorney General was in Virginia, the Custom 
House at Chester and the Post Office in a stable beyond the limits of the city. Near the banks of the Schuylkill were scores of tents where food and shelter were given to the poor. Five hundred and twenty laborers, thrown out of work, were put to mending the roads at seventyfive cents a day. But when the money appropriated by the Legislature began to run low this pittance was cut to fifty cents a day and the public was called on for aid.

"Our city and its inhabitants," Girard wrote to Bentalou in August, " are in a deplorable condition. Our Board of Health, our College of Physicians, or rather jackasses, not to mention our governor's proclamation which does not even show the common sense of a half civilized nation, have created an unparalleled state of alarm. For my part, I assure you that I feel the greatest fear lest most disasterous consequence may follow."

"The false alarm that has been spreading in our city for some time increases as more citizens desert the city. I doubt if there is a place in the world where an utterly baseless panic has ever been pushed to the extreme it has here. I now see myself forced to play a part against the yellow fever and therefore, in behalf of those in distress, I hope the epidemic will not be as bad as that of 1793."

In a letter to Ferrers in New York he declared that although, "owing to improper publications many of our citizens are alarmed, and others have deserted our city, I can assure you that within this twenty years I have not experienced a month of August more favorable than this to the health of our inhabitants."

So convinced was he that the panic was groundless that when the Board of Health was about to adopt a set of resolutions stating that the fever was contagious, he, with Lownes and Connelly, asked leave to withdraw from the meeting before the vote was taken. 


\section{THE LIFE AND TIMES OF STEPHEN GIRARD}

For this he was attacked by Dr. William Currie, who had a quarrel with the Board for not sending to the physicians for returns of their yellow fever patients. In the course of his public letter of complaint, Dr. Currie remarked that it was reported that Dr. Shippen had asserted there was "no contagious disease in the city," that the excitement was a "mere South Sea bubble," and that "It is also reported that a similar opinion has been delivered to the Board of Health by Messrs. Girard and Lownes." This was amazing as "none but men insane can possible resist the torrent of evidence to the contrary."

Girard at once replied in a letter addressed to the editor of the Aurora. "I have just observed that in the Gazette of the United States of the 3Ist ult, doctor William Currie, one of the heroes of contagion, has taken the liberty to give some hints respecting my opinions on the present disease. Permit me to inform him, through the medium of your paper, that at a future period he and his associates will be set right and convinced of their ignorance."

"I beg to inform him," wrote Currie in reply, "through the channel of your paper, that before I can submit to be instructed by his lectures, I must be informed how and where he acquired his superior knowledge of the nature and laws of disease, and shall also expect him to explain what he means by a contagious disease."

Commenting on this letter the editor observed that Dr. Currie was entitled to think as he pleased, but "deserved severe reprobation for attempting to cast a stigma on Stephen Girard for an action (Currie had referred sneeringly to Girard as a good nurse) on account of which that citizen deserves to be immortalized. Stephen Girard in 1793 and in 1797, has from pure motives of humanity devoted himself to a laborious superintendence over a 
hospital for persons ill of a highly dangerous and malignant disease, and his labors in this line well may be said to have been the saving of more lives, perhaps, than Dr. Currie ever preserved in the course of his practice."

In letters to correspondents Girard gave his description of the condition of the city and his opinion of the physicians.

"Here we are my dear Hourquebie, in the midst of the greatest alarm. Our infamous esculapians, who have the impertinence to call themselves physicians, have raised an alarm and say that the yellow fever is at the entrance of our city. The result has been the barring of our streets, the flight of our citizens and the desertion of our city so that none but the poor remain. But in spite of all this the contagion that we have been told for a month has been threatening us has not yet put in an appearance. We have not the slightest sign of an epidemic. Whatever may be the outcome I am forced to be at my post in expectation of the enemy. This state of affairs has caused the greatest stagnation in business except in the Banks which are trying to collect the funds they have outstanding: but those who are to pay them are wisely staying in the country."

"My daily duties," he wrote Bentalou, " are so engrossing that I have no time to attend to my own affairs." "A number of our physicians maintain that we have a contagious disease in our city which is catching at a distance of ten feet. One of them took the liberty to ridicule my opinion through the medium of a newspaper. I answered him, in the same manner, as he deserved. The newspapers of Brown, Bache and Dunlap will inform you about it. I wish you would warn people about it, so as to create a distrust for this kind of executioners of the human species." 
Writing to a friend in Wilmington on business (sixteen Philadelphia firms had advertised their removal thither), he asked, "should you be able to raise by subscription any money for the support of those sick persons who are not willing to be removed from their homes, please do it as early as possible so a proper care may be taken of them, and confidence and tranquility may be restored to our citizens. Our city continues as healthy as ever it was in the present season."

This was in reply to a letter from Mr. Jacob Shoemaker: "The nature of the business thou hast undertaken is such that it seems intrusion to give the trouble of even reading a Letter, but as I proposed collecting some money among the Philadelphians here for the use of the Poor in the City, I shall just give the reason why I have not done it. Among the numbers who have flocked here are many who are distressed and some melancholy instances of Death have occurred, one in the Road near this town. In consequence of which, in conversing with Robert Ralston, We concluded as the Assembly hath granted $\$ 10,000$ for the Use of the Poor, it would be more necessary to turn our attention to those here, to find some means of subsistance as well as a shelter in case of sickness but still, if help is wanted, on being informed, we will step forward."

"The situation in our city," he told Ferrers, "is really lamentable. The greatest part of the wealthy inhabitants have deserted their homes. Indeed very few are left except the poor class of our citizens, from which it follows that the latter are in want of the first necessaries of life which are Exercise for the body and nourishment for them and their families. The result is sickness which, added to the shameful alarm of contagion which was spread by ignorance or by ill disposed persons, strikes the sick with fears, and terror prevents others to take care 348 
of them, and finally cause the death of three fourths of those who are daily carried to their graves."

"For about a month," he informed Massac \& Co., "we have been in a state of the greatest alarm. Our college of Physicians, composed of ignorant charletans, has persuaded our citizens that they have in their midst a contageous fever. The result has been a general flight so that there is nobody left in town except the poor who are without work and in the greatest distress and daily succumb to the disease. In all this disorder I have again been appointed inspector of health and director of the public hospital. The latter office is giving me a great deal of trouble and prevents me corresponding with my friends, I hope you will accept this as an excuse."

From Chester Mr. John Harrison wrote, "As we have made a small contribution for the Relief of the Poor Distressed Citizens of Philadelphia I would Thank you to Inform me where and in what Manner we shall Deposit the money."

"Mr. John Connelly, Mr. Caleb Lownes and I," was the reply, "have been appointed for the government of the Public Hospital. In the course of our duty, particularly when some of us are visiting the sick in the city and suburbs, many objects of charity come under our notice. Should you be desirous to have your funds applied for that purpose, by addressing them to either of us they will be distributed to proper objects." In time $\$ 158.30$ were forwarded. Attorney General Ingersoll sent an order on the Controller General for a quarter's salary, due October Ist, of which Girard was to keep $\$ 30$ for relief of the poor. Others sent him $\$ 60$. He himself contributed one hundred dollars. Mr. Samuel Chew, then at Chester, gave a hundred. The Philadelphians in Wilmington raised one hundred dollars and as much more came from the citizens of that town. 


\section{THE LIFE AND TIMES OF STEPHEN GIRARD}

Despite his work in the Hospital Girard found some little time to attend to business. In August 1917 just at the outbreak of the fever the Voltaire arrived from Europe.

At Hamburg her cargo of coffee, logwood and sugar came to a good market and netted 160,396 marks banco, and the freight 2342 . Thence she had sailed in ballast for St. Petersburg, the first of his vessels to make that port, and had there taken on a cargo worth 191,450 rubles and docked in Philadelphia in August. With the arrival of the Good Friends, the Liberty and the Sally, and the launching of a new brig, the Modest, in November, Girard had all his ships in port. But they were soon scattered. The Good Friends went to Virginia for tobacco, the Voltaire with sugar and coffee sailed in December for Hamburg and St. Petersburg, and Modest with $\$ 16,423$ worth of logwood was despatched for Hamburg.

Why she did not go to San Domingo was explained to a correspondent.

"American vessels navigating your waters run so much risk at present that I have decided to give up all idea of sending any ventures to your island for the present.

"If the much desired peace is concluded, I intend to use this vessel and the Sally constantly in trade between Philadelphia and your island, and then you will see how little I am inclined to change my mind. I do not. even say that I shall not send you one of my vessels even if the European despots persist in the war."

The much desired peace was not concluded. France, since 1795, had made peace with Prussia and with Spain, had taken over Belgium, had reduced Holland to a vassal ally, had signed preliminary articles with Austria in the spring of 1797, and in July had sent three deputies to meet Lord Malmesbury at Lille. But, in an evil hour, on 
the memorable fourth of September, the Directoire made itself master of France, imprisoned the Constitutionalist leaders of the Corps Législatif, reduced that body to subjection and gave Lord Malmesbury four-and-twenty hours in which to leave France.

"The peace negotiations," said a correspondent, "have been broken off. Lord Malmesbury left for England on the $16^{\text {th }}$ instant and war is about to break forth afresh between France, the Emperor, and England. Poor Humanity! How little you are consulted in these matters."

Said another, "Judging from the public views, the prospect of peace between France and England has vanished and as the differences to be settled between these two powers are so many and so important, it is to be feared that the war will not be brought to an end in the course of this year."

Records preserved by Girard show that just at this time he was actively engaged in a bitterly contested election, and make known to us some political usages of those days. Again he was nominated by his party for Select Council, and again, with his party, he went down in defeat. One candidate, Israel Israel, alone seemed to have been elected to the State Senate from the district comprising the Counties of Philadelphia and Delaware. But the Federalists protested that in Moyamensing and Passyunk the polls had been held at places not appointed by law, that the Judges had questioned no one; that men not citizens had been allowed to vote; that the number of unlawful voters was greater than the majority of $\mathrm{Mr}$. Israel over Mr. Morgan, and petitioned the Senate to refuse Mr. Israel a seat. The prayer was heard, an investigation was made, the committee sustained the charge of illegal voting, the election was declared void and a new one ordered to be held on Washington's Birthday 1798 . 
Feeling in the district now rose high, both parties spared neither money nor pains to bring out their supporters, and into this contest Girard entered with hearty zest. He attended a Republican meeting, in the North Mulberry Ward, at which a committee, of which he was a member, was duly appointed to arouse the party voters, and collect the needed funds. From a subscription paper he preserved it appears that

"The Committee appointed on the $4^{\text {th }}$ instant by a Numerous Meeting of the Citizens of Philadelphia held at the house of John Miller in North Mulberry Ward having met.

\section{Resolved Unanimously}

That a Subscription be opened in order to defray the Incidental Charges attended upon the Election of a Senator for the district composed of the City and County of Philadelphia and County of Delaware to be held on Thursday next the $22^{\mathrm{d}}$ February 1798 and that we whose names are hereunto subscribed do agree to pay into the hands of Citizen Stephen Girard as Treasurer for the said purpose, such sum or sums of money as are Severally and Respectively affixed to our names.

February $20^{\text {th }}$ 1798."

Girard, Thomas Leiper and Leopold Nottnagel gave thirty dollars each, James Sharswood and many others ten dollars each. In all \$419.29 was collected and used for the good of the cause. His account book shows that $£_{3}$,O I I was spent for "printing 500 handbills in German respecting the election of Israel Israel Senator"; that some went for taxes to enable certain persons to vote, some to William Duane and others for "services in the contested election of Mr. Israel"; some to a "Trumpeter," for there were street parades; some to "a Bellman to notice 
the inhabitants," some for "Putting up Circular Letters and distributing them"; \$189.60 for "I Silver Sarver," and \$186 for another "Silver Sarver."

This expenditure of money was of no avail. The Federalists rallied, and Mr. Israel was defeated by 300 votes. The election over, Girard went back to his business affairs and early in March the Sally, John Dorson, Master, and Martin Bickham, supercargo, was despatched for the Isle of France, or, if it should seem better, for the Isle of Bourbon.

Mr. Bickham, who thenceforth to the death of Girard served him in many capacities, as supercargo, factor, agent, correspondent, had been trained in his counting house, and had gone thence to become a member of a firm which failed one day while Mr. Bickham was seeking business in San Domingo, leaving Girard to settle for many notes he had endorsed out of regard for his young friend. Unable to do business at home, Mr. Bickham gladly went to the Isle of France, there to establish himself, with the help of commissions from Girard, should trade with the island warrant adventures. The value of the cargo entrusted to his care was $\$ 56,950.29$.

The departure of the Sally was quickly followed by that of the Liberty for Cuba, and all five vessels were thus away from their home port. The value of the ships as stated by Girard was $\$ 70,000$ and that of the cargoes $\$ 287,350$. That his ships and raror $s$ were likely to be exposed to the risks caused by a war with France he was loth to believe. Nevertheless, when dispatching the Voltaire in December, his Hamburg correspondents were requested, "in case the United States should be involved in the present war and my ship Voltaire should be in Hamburg at the receipt of this letter, and no orders have been given to Messrs. Bulkeley, Russel \& Co. for the purchase of the 


\section{THE LIFE AND TIMES OF STEPHEN GIRARD}

return cargo from St. Petersburg, please to have the Voltaire coppered, as before mentioned, and send her back immediately," with freight or in ballast, insured "in your city by safe underwriters against all risks from your port to this, valuing the ship etc., at 60000 marks banco."

Should the cargo have been purchased at St. Petersburg "and we should be involved in the present war, the Voltaire must proceed to St. Petersburg" fully insured, "but in case our political affairs should remain as they are, or a general peace should have taken place," ship and cargo were to be insured for but three-fourths their value.

William Douglas at Petersburg was requested to hold the Good Friends. "Reports which are now circulating and said to be from Norfolk are alarming. Should my ship be still in your river and you should have strong reasons to fear that we will be involved in the present war please to detain her until next post."

His fears were soon allayed and by the next post he wrote: "Having reason to suppose that the alarming news, which has for some time circulated in our city, is principally fabricated by persons who wish to see our country involved in a war, I beg you will dispatch my ship Good Friends for Bordeaux."

"Though our speculators are making every effort to persuade us that we are, or will be shortly, involved in the present war, I do not see any appearance of a rupture without hostilities should be commenced by this country. This I expect will not be the case."

Hourquebie, to whom the cargo was consigned, was now told: "We have within these few days very unfavorable reports from Paris respecting the reception of our Commissioners, but, as I expect my ship Good Friends is 


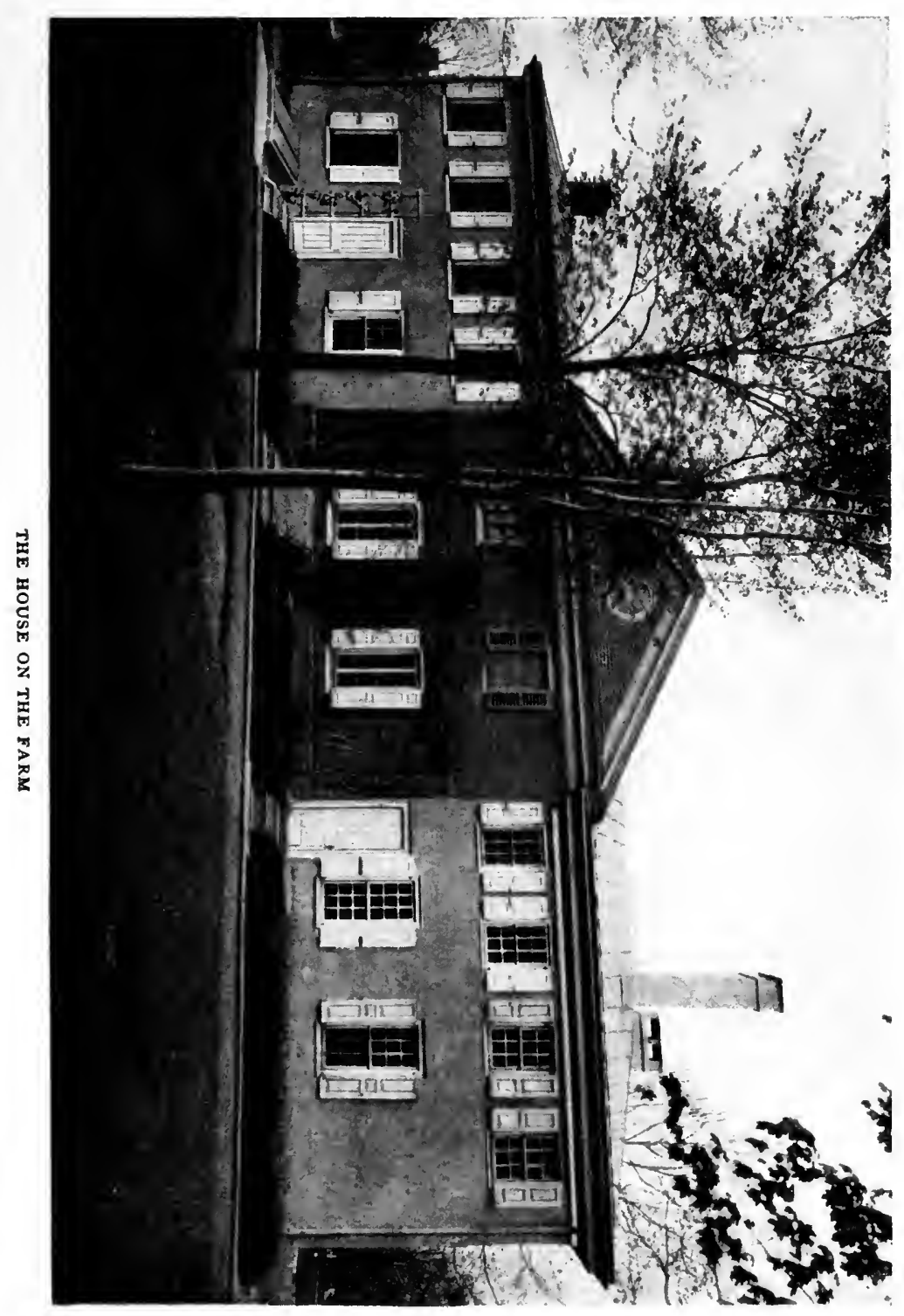



ready to sail and as I have no confidence in the circulating news, I have requested my friend, Mr. Douglas, to dispatch the Good Friends for Bordeaux."

"The gossips here talk a great deal about war. I do not agree with them, and think, as do many others of our citizens, that unless some European power declares war against us we will keep the peace so much to be desired. Nevertheless, as it is necessary to protect my funds I beg you, in case of rupture or danger, to put them in a safe place either by depositing them for my account with Berenberg, Gossler \& Co., of Hamburg, or in any other way you think safe."

"As I have lately come into possession of two proper ties in the country situated three miles from our city on the road to Fort Mifflin, I beg you will send me by return of the ship Good Friends some roots of muscot vines and any other good white grapes."

The "two properties in the country" were two tracts of land, "plantations" he called them, one of seventy and one of five acres bought in December, I797, and August, I 798, for \$1 5,532. They lay in the township of Passyunk, then well without the south boundary of the city, and on them he established his farm. To the day. of his death money and care were lavished in the effort to have none but the best breeds of sheep and cattle, and the finest fruits, and vegetables grown from selected seeds. As the furnishings of his house in Water Street, his mirrors, chairs, sofas, his rugs and china came in his own ships from Bordeaux, so his vines, his fruit trees, and his seeds were imported from Spain, France and Holland.

Before a ship could be found to carry his letter to Hourquebie the report that our Commissioners had not been received by the Directoire was confirmed and in the postscript he said: 


\section{THE LIFE AND TIMES OF STEPHEN GIRARD}

"We have received more bad news. We are assured our Commissioners have not been received. I hope this will have no bad effect on the commerce between France and the United States."

When Congress closed the special session of eight weeks in the Spring of 1797 money had been voted for the defence of the coast; three frigates had been ordered to be armed and manned; authority had been given to the President to call on the States for eighty thousand militia to be ready to march at a moment's notice; and Elbridge Gerry, John Marshall and Charles Cotesworth Pinckney had been appointed envoys to settle the trouble with France. They reached Paris in October, I797, and were given letters of hospitality but were not received by Talleyrand, the Minister of Foreign Affairs. In his stead, came, one by one, three men who stated that the Directory was much incensed against the United States, and that, before the Commissioners could be received they must apologize for certain passages in President Adams' speech to Congress when it met on May fifteenth, pay a sum of money to each of the five Directors, and make a loan to the Government. The gift, or bribe, must be $1,200,000$ livres, or $\$ 250,000$, which would be $\$ 50,000$ for each Director. As to the loan, in plain English the tribute, the United States might buy from France at par thirtytwo million florins of Dutch rescriptions then worth not fifty cents on the dollar.

Not a cent would the Commissioners give. They were then reminded with what sort of men they had 'to deal. America, they were told, had paid money for peace with the Algerines and the Indians, and if she could do this with savages, she could do it with France. Nothing could be done in France without money.

The people read of this with scorn and indignation, 
an outburst of patriotism swept over the country, and "Millions for defence; not a cent for tribute" became the popular slogan. In every city and town meetings were held, resolutions adopted and patriotic addresses sent to the President. Young men formed "Associations for Defence," mounted the block cockade of the Revolution and drilled diligently. In the seaports money was subscribed to buy and equip ships of war, and, as in 1794, men of all walks in life went forth to labor on the forts and earthworks. Congress suspended the old treaties and prohibited all intercourse with France and her colonies, authorized a provisional army, made Washington Lieutenant General, created the Navy Department, laid a direct tax and voted money for arms, ships and fortifications.

Cutting off trade with France and her colonies was bad enough, but a new British Order in Council laid restrictions which affected Girard far more, for one of his ships came under it. This Order, dated January $25^{\mathrm{th}}$, I798, revoked the orders of 1794 and bade the commanders of British ships of war and privateers seize and bring in for adjudication all vessels laden with goods the produce of any island belonging to France, Spain or the United Provinces, and going direct to any port in Europe not a port of the Kingdom of Great Britain, nor a port of the neutral country to which the vessel belonged.

When the Sally was cleared for the Isle of France she was to go thence to Hamburg before her return to Philadelphia. Should the voyage be carried out she would fall under the order, for she would be laden with produce of a French island and going direct to Hamburg, a port in Europe not belonging to Great Britain, nor to the neutral country whose flag the Sally bore.

Girard accordingly made haste to change instructions 


\section{THE LIFE AND TIMES OF STEPHEN GIRARD}

and by a letter, sent by the first ship bound for the Isle of France, Mr. Beckham was requested to send the Sally directly home.

"In consequence of the British new Orders here inclosed, I request that you will lose no time in dispatching the brig Sally direct to this port, instead of going to Hamburg." Captain Dorson was to "avoid as much as possible speaking any vessel" on the way home, "and in coming on our coast to make the land off Cape May, in view to keep off the cruizing ground of armed vessels."

Sebastian Lasa of Havana, to whom the brig Liberty was consigned, was told, that "the present political state of our affairs particularly the ill treatment which our flag received daily from some of the belligerant powers induces me to request as a particular favor that you will dispatch said brig Liberty as soon as possible for this port, with a cargo of sugar and specie amounting together to $\$ 50,000$, observing that I do not wish her return cargo to exceed that sum." The rest of the proceeds of her cargo to Havana was to be held until further orders.

"The gloomy prospect of our political affairs," he wrote Douglas, "give me a great deal of uneasiness particularly in regard to my maritime operations." To Bentalou he said: "As to business it is in the greatest stagnation. Thanks to our treaty the people here are greatly embarrassed. Thank God, I have not much merchandise in the warehouse, but on the other hand all my vessels are out with valuable cargoes which run the greatest possible risks. We must hope that all of them will not be lost and that I shall be fortunate enough to escape the great shipwreck which threatens our maritime commerce."

Letters from correspondents in Lisbon, Rotterdam, Amsterdam; Hamburg, Bordeaux, on the other hand, gave most alluring accounts of trade conditions. Schroeder, 
Ermann \& Co. of Amsterdam, in January, were sure "that by next spring products of the Isles and of America will reach very high prices." American tobacco sold at "enormous prices." Cotton, indigo, logwood, leather would all yield " a great profit to the consignor." It then looked "as if peace would be restored on the continent in a few months. On the sea hostilities will, on the contrary, be resumed with new vigor. The French privateers recently captured several American vessels coming from America and bound for this port, or for Hamburg, on the pretext that their papers were not in order. Other vessels with which no fault could be found in this respect, were allowed to go on unmolested. So you see the American flag is still respected if the Captains will only provide themselves with the necessary papers. Any neutral vessel bound for, or coming from, an English port and having on board a consignment of merchandise, the product of the British Isles, regardless of the person for whose account the merchandise is shipped, will be seized and confiscated for the benefit of the French Republic."

A firm in Rotterdam assured Girard that prices were "uncommonly high and every circumstance contributes to forsee a further rise." Moreover, "since the French Directory has taken the Decree, of which enclosed is a copy, which will prevent our receiving any goods from England, our only resource will therefore be what we receive from America."

Hourquebie wrote in March, "I think $I$ am justified in telling you that if your sugar arrives here soon enough to take advantage of the present state of the market, she (the Good Friends) will not make a long stay here and I shall send a return cargo of at least 300,000 livres tournois." But he must be careful "to get a certified statement from the authorities that whatever coffee or sugar 
you send here comes from the French, Spanish or Dutch colonies, and do not load any from the English colonies. This precaution is rendered necessary by the decree which declares lawful prize any neutral vessel found to have on board merchandise of English make."

A voyage of forty-eight days from Virginia brought the Good Friends to Bordeaux and a fine market. Her return cargo was valued at 308,055 livres. A dollar was rated at eight livres, five sous.

Girard, then furnishing his new house, had requested Hourquebie to send him a mahogany sofa, twelve arm chairs covered with blue damask, or satin, "finished as plain as possible," three oval looking glasses, with gilded frames, two feet, four inches wide, "french measure from outside of the frame," and one hundred pounds of horse hair, called "crin frisé," of good quality for mattresses, and "Twelve large hens with large combs and two cocks." Hourquebie reported: "I had a good deal of trouble to fill your order for the easy chairs. There was not an upholsterer in Bordeaux who could get the material to make them for me, and it was only yesterday that I succeeded in buying six, with two arm chairs, a sofa in modern style, and a pair of gilt andirons."

As June and July passed away and the Good Friends did not return Girard grew more and more anxious each day. "I notice," he wrote Bentalou who had joined the volunteers, "that your time is occupied principally in training men and horses. I ardently hope that the lessons you give will never bring to you unpleasant thoughts. As for myself, neither my age nor my principles will permit me to take part in a war. I prefer to run greater risks and have the satisfaction of using the rest of my career in attending to my own business, and to the preservation of the human race." 
"Apropos of business you are fortunate, my dear friend, in being able to forget the great interests which you have at sea, for I fear at this moment to lose the fruits of many years of hard work. I promise myself to be more prudent in the future."

And again, "I am still without news of my ship the Good Friends. I am looking for a new brig, sheathed in copper, coming from Hamburg with a rich cargo which I expect to send to Havana. But I do not wish to talk about it. I fear it may be the same with my maritime ventures as with my place in the country which is not prospering any too well. For some time the locusts have destroyed everything, and the crops are hardly worth harvesting. They destroyed the garden truck, the meadows, etc, and devoured all the clover I had sewn. I fear that the dangers of the sea may do the same to my vessels."

His anxiety as to the Good Friends was at last put at rest by the arrival of the brig.

"The arm chairs," he wrote Hourquebie, "and the sofa are damaged. It is unfortunate this furniture was not more carefully packed before it was shipped. I beg you will send me by the return of the Liberty enough to cover two chairs, the front of the seat of the sofa, all the top of the cushion of the sofa with an extra quantity for trimming."

The Liberty had sailed from Philadelphia April 2nd, 1798, and three weeks later reached Havana to find the harbor full of American vessels. Sebastian De Lasa, to whom the cargo was consigned, reported that he would "try to get the vessel ready in a week because there is a rumor that an embargo is to be laid within that time which will probably last two or three months. Whether the embargo comes or not, and without waiting to sell 
any part of your cargo, I obtained permission from the Custom House authorities to unload this morning (April 29) and to load sugar this evening. That is why I am guarding against our losing the vessel by the embargo; in any event she will have a full cargo of sugar."

"I found it absolutely necessary to pay 5 gourdes for each barrel of flour on board the brig Liberty, to the person from whom I obtained permission to unload, for the special indulgence from the King, and the duty which amounts in addition to $I \frac{1}{2}$ gourdes. But this will be made up by the price of 24 gourdes per barrel which I think I shall be able to get if the quality is fine."

"Moreover, besides paying the duty, the 5 gourdes must be paid now and in cash, on condition that you are allowed to send a thousand barrels more at your convenience." * * *

"I hope you will approve of this procedure and will not lose the chance to send 1000 barrels more. I advise you to send them by two small shipments of 500 to 600 barrels each, so that they will arrive one after the other at an interval of 19 days. If you find it necessary to send 100 or 200 barrels more than 1000 , they will be admitted without any trouble provided a proportionate bonus is paid. In fact, I was forced to pay 8000 gourdes before they signed the permit."

May I2th the Liberty sailed for home with a cargo of sugar invoiced at $\$ 52,0851 / 2$. Up to that time so much of the inward cargo as had been sold amounted to $\$ 70,7091 / 2$. "I made out a false account of sales which you will find among the brig's papers. My only object in doing so was to protect the sugar and to avoid giving the English privateers the slightest excuse for seizing the vessel. You will therefore understand that, so far, nothing has been sold except what I told you 
about in my last of the gth of this month, and the said account is of no value, whatever, any more than the contents of my Spanish letter, of even date, (I2 May) relating to the same subject which I wrote very carefully so as to enable the privateers to read it easily."

On no account should you "risk any English goods whatever on the vessel you send to Havana, for the coast is swarming with Frenchmen who seize every American with the smallest quantity of English made goods on board." A postscript announced that all of the 1000 barrels of flour had been sold to the bakers for 24 gourdes per barrel.

"Not knowing what to do with my brig Liberty, lately arrived from Havana," he wrote Bentalou, "I have decided to get a permit to make her a cartel and send her to Bordeaux with passengers. As I need many more to make up the full number, I beg you will procure any in your power. My price is 100 gourdes for each person, little children in proportion. They will be furnished with water, biscuit, rice, peas, beef and salt pork. Some consideration will be shown those without means."

In response to his advertisements 82 passengers were secured, of whom 32 were for the account of the French Republic. Most of them were officers of the French army. Among the passengers were M. Oster, the French Consul, and Girard's old friend and fellow worker at Bush Hill, Dr. Jean Deveze.

A letter to the Secretary of the Treasury on July I 4 th, 1798, explained the purpose of the voyage. "Having a considerable property in France, principally in the hands of my agent, residing in the city of Bordeaux, in the beginning of last month I resolved to dispatch for that port my brig Liberty, as a flag of truce with passengers, under the command of Mr. Thomas Lillibridge. In consequence of 
that resolution I obtained immediately the promise of the necessary passports and on the 30 Ulto I cleared said brig at the Custom House. Since that period my brig having been detained in this port by the passengers, I beg that you will grant to Capt. Thomas Lillibridge a permission to proceed with the brig Liberty having on board ballast, passengers with their baggage, and provisions, to Bordeaux."

Captain Lillibridge was to maintain "strict subordination among the crew and passengers, to treat them with the greatest humanity, also to take good care of the sick and whenever some preference is unavoidable to give it to children, women and ancients. Among the plentiful provisions which you have on board there is two firkins of butter which I beg you will give out to the poor passengers."

Should the French government refuse permission to take on a cargo at Bordeaux, the Liberty was to return as a cartel.

August 24 the Liberty arrived and Hourquebie wrote that he had received the "bill of exchange for 16,537 livres, Io sous tournois, drawn on the Paymaster-General of the Navy in Paris. We shall forward the same for acceptance and payment when it falls due. We hope we shall be more fortunate in this respect than the consignee of the cartel ship which will bring you this letter; for he has not succeeded in procuring payment for similar drafts for payment for the passengers he brought to France at the expense of the Republic."

The Modest, which left for Hamburg in March, arrived home in August with a cargo invoiced at 133,7 I6. I I marks banco, and entered the harbor of New York short of water. On her arrival at Philadelphia no time was lost in loading her with a cargo valued at $\$ 94,693.34$ and 
dispatching her early in September for Havana with Mr. Alexander Dobignie as supercargo. The correspondent at that city, Sabastian De Lasa, was told that "being desirous to postpone any shipments to the West Indies until our flag is more respected by the belligerent powers, I am anxious to settle my business in that part of this globe, and consequently have given my power of attorney to my particular friend, Mr. Alex. Dobignie, for the purpose of settling all my accounts with you and to receive the money due me or the goods if unsold."

"Though present circumstances oblige us to suspend business in your city, I flatter myself that a change in the conduct of the powers at war will induce me to renew shortly our Correspondence." The Modest was then insured for $\$ 10,000$ and the cargo for $\$ 65,000$ and nothing was heard from her till October 15 th, when a letter from New Castle, written by the mate, announced, "I am sorry to acquaint you with the loss of your brig Modest. She upset in a squall near the Keys, part of the crew have arrived here this afternoon (Oct. 12) in a vessel from the Môle. Capt. George was landed in No. Carolina about two weeks since." October 26th Captain George arrived, bringing with him a letter from Dobignie, stating that the Captain "will give you a detailed account of our misfortune and shipwreck which is the most extraordinary that has ever been seen. It is largely due to his courage and coolness that we were saved. * * The sailors and the mate, the entire ship's company in a word exerted themselves in every imaginable way. Until the time of our accident we had made splendid time and everything was in the best possible order. The Captain had kept a lookout and we had accordingly avoided a number of sails as the Captain can tell you better in two minutes than I could do without giving you all the minute details you 
will obtain from him. The poor fellow was greatly cast down and I needed all the philosophy and calmness at my disposal to console him."

The letter was written "On board the 'Pourvoyeuse' September 19th, 1798, 9 o'clock in the morning." The Pourvoyeuse was a privateer concerning whose Captain, Mr. Dobignie wrote: "I should be ungrateful if I failed to tell you with how much zeal, with what loyalty, with what generosity we have been treated and are still being treated at this moment. I am on the most friendly terms possible with the ship's company and there is not an offer of service which the generous and humane Olarner, Captain of the privateer La Pourvoyeuse has not made. Captain George will tell you about our reception and the efforts he made by fly to our rescue, although he is short of water and provisions, which makes it a thousand times more noble on his part to have held out a helping hand to us in our misfortune."

From the "Protest" it appears that "on September I 4 being in lat. 29 or thereabouts and long. by calculation $75^{\circ}$ ", the brig encountered "a heavy and sudden squal" which came "without any previous appearance until it struck." By the utmost exertions of all the crew the main sail and top sails were brought down, and two of the crew were handling the top gallant sails, when "the squall came on with that severity that in almost a moment the brig upset and with that force that the heads of the masts were so low in the water that after cutting away the weather lanyards the masts would not go, and as she upset the three lee cabin windows were all under water, which soon admitted so much water that it water logged her and her so heavy that we found it impossible for her to right although her masts had been cut.

"Our greatest exertions were then to save the boats 366 
and ourselves. At about one o'clock of the same day the crew left the wreck in the long boat and yawl with three barrels of apples, one small cask of water, five boxes of wine, one compass, one escretoire and one small trunk of wearing apparel which floated out of the cabin and which we picked up. In this situation and steering S. S. W. with the boat, and finding the small boat too heavy, after clearing her, we cut her adrift. Between three and four o'clock the same day we made a sail to leeward. About four o'clock we got aboard her; the French schooner Preyoyuse. Captain Peter Olanyer from Gonaives who took us on board and treated us with civility. On the $19^{\text {th }}$ we fell in with a brig from Petit town bound to Philadelphia. Captain Richard George with five men and two boys went on board." But the mate was detained on board the Privateer by Captain Olanyer and taken to Baracoa and finally reached Havana.

Heavy as was the loss, Girard bore it with an unconcern worthy of his favorite Dr. Pangloss, and in a few words dismissed it from his mind. "Without stopping to talk of the heavy loss to me by the accident to the Modest," he wrote Dobignie, "I beg you will not think too much about the past. We must now plan to repair our losses. This is the best thing for us to do."

During the summer some good news came from London concerning the long lost Polly. Claims for damages in the case of the Sally and the Polly had been filed with the Secretary of State in November, 1794, and forwarded in April of I795, to Mr. Samuel Bayard, the Agent appointed by the Government to press the claims of Americans.

Shortly after Jay reached London, in June, I794, at a conference with Lord Grenville, he took up the matter of captures and spoliations and was surprised to learn that not a case, under the orders in Council of November 6, 
1793, had been laid before his Lordship. At a later conference, therefore, Jay presented an official statement, complained of the irregularity of capture, the injustice of condemnation, the great and extensive injuries done to American merchants, the grievous costs and delays attending suits, and the necessity for revision and correction, by the Court of Appeals in London, of the sentences of the vice admiralty courts in the colonies.

Lord Grenville gave assurance of His Majesty's wish that full and impartial justice be done the merchants and August 6th, 1794, this Order in Council was issued:

"Whereas, in many of His Majesty's vice admiralty Courts in the West Indies sentences of condemnation have passed against ships and goods belonging to subjects of the United States of America; And whereas, from ignorance of the rules respecting the time of appealing, or from inability to find the security required, or from other and reasonable impediments, the claimants have been prevented from duly entering and prosecuting their appeals from the said sentences; And whereas it hath been represented to His Majesty, on their behalf, that they are desirous of entering and prosecuting the same; His Majesty is thereupon pleased, by and with the advice of his privy council, to order, and it is hereby ordered, that the said parties shall be admitted to their respective appeals, notwithstanding the ordinary times for entering and prosecuting the same may have elapsed; provided the same are entered and prosecuted in a reasonable time to be approved by the lords commissioners of appeal in prize causes."

"You will perceive," Jay wrote to Randolph, "that they who wish to prosecute either appeals or claims, should, without delay, appoint agents here to manage their business, to whom I may deliver such papers in my posses- 
sion as relate to those cases of capture which may be committed to their care and direction."

That the merchants might "have precise and plain instructions relative to the prosecution of appeals and claims" Jay applied to Sir William Scott and Dr. John Nicholl to prepare them.

October I8th the letter of Jay enclosing the Order in Council reached $\mathrm{Randolph}$ and the next day it was laid before a body of merchants summoned to confer with him on the capture of their vessels. So many came that it was impossible to do business and at his suggestion a standing committee of five were appointed to consult with him from time to time.

By this committee Mr. Samuel Bayard was chosen as agent. All costs attending claims and appeals were to be borne by the United States. Washington approved the choice of Bayard, and Jay was duly authorized to instruct him how to proceed as "agent to manage claims and appeals in cases of irregular or illegal capture or condemnation of American vessels or other property, under color of authority of commissions from His Britannic Majesty." Bird, Savage, and Bird, London merchants, then agreed to become sureties for the payment of such costs as might be decreed against any claimant or appellant, the United States pledging itself to indemnify the firm for any losses sustained, and in January I795 Mr. Bayard took up his duties as agent.

Hearing nothing from Mr. Bayard, Girard, in October I795, requested that he would take "every step to bring on my trial as soon as possible so that I may know what I have to depend on." When no reply came he wrote again, in January 1796 :

"I am one of the unfortunate American merchants who has suffered the most during this last European war. 


\section{THE LIFE AND TIMES OF STEPHEN GIRARD}

My claims against the French are considerable. As to the British they have taken, on the 25 th of February, a brig called the Sally, Captain John Cochran, Master, vessel and cargo owned between said Captain Cochran and me, coming from Aux Cayes a port in the south side of Hispaniola, bound for Philadelphia, carried her to Kingston, Jamaica, and after having detained there said vessel and cargo (which they had landed) for about three months have permitted Captain John Cochran to proceed with his vessel and cargo to his destination without reimbursing any charges or allowing him any damages.

"On the Igth day of April following a Bermudian privateer called the Enterprise, commanded by one Joseph Robinson, has also taken my brig Polly, John Congdon, Master, from Basseterre in the island of Guadeloupe bound for Philadelphia loaded with West India produce and some specie and carried her to Bermuda and on the I4th June, 1794, said brig Polly and her cargo were there condemned under pretention that said vessel was from a French port which was under Blockade. The loss which I have sustained by this condemnation amounts, exclusive of damages and Interests, to 23947.94/100 Dos and the Damages sustained by the capture, detention etc. of the brig Sally and her cargo amounts to $\$ 866667 / 100$. I have entered in due time an appeal at Bermuda in the case of the brig Polly and cargo, and have appealed to our government for the recovery of my losses. They have sent on the 4th of April 1795 the original Copys of the proceedings of the Admiralty Courts etc. of Jamaica and Bermuda to Mr. Samuel Bayard, a Gentleman of the Law who was sent from this City to London for the purpose of settling the Losses which the citizens of the United States have sustained by captures etc. from the British."

Messrs. Thellusson Brothers \& Co. were then asked 370 
to forward the enclosed letter to Mr. Bayard and aid him if possible in pushing the claims. This was done and in April Mr. Bayard answered:

"I am sorry I can give you no satisfactory information respecting your two claims under my care. They are en train, but when they will be brought to decision depends on so many circumstances over which I have no control that it is impossible for me to say when absolutely you may expect to hear their conclusion." No more was heard of the matter till February 1797, when Bayard wrote: "In order to obtain compensation for the loss or damage sustained. in this case (that of the Sally) you will please to furnish me as soon as possible with further proofs required by the above gentlemen to whom cases of costs and damages have been referred for a more early and equitable settlement than could be had by way of appeal."

The "above gentlemen" were William Scott and Dr. John Nicholl, who wished to know "the tonnage of the vessel, the value of the cargo and the nature and quantum of the damage alleged to have been done to the vessel and cargo."

Nearly a year passed before Girard, on January I3, 1798, replied. The Sally was taken, he said, on February 25, 1794, reached Kingston, March Ist, was acquitted May 20th, sailed June 2nd, and reached Philadelphia June 26th, "which shows that the brig Sally was detained at Kingston upwards of three months during which time the heat of the climate, together with worms, occasioned such damage to the hull and bottom of said vessel" that repairs cost $\$ 1077.48$. For demurrage he claimed $£_{300}$ Pennsylvania currency, or $\$ 800$ per month. For trial charges, landing, storing, reshipping cargo, $£_{550}$ Pennsylvania currency, or $\$ \mathbf{1 4 6 6 . 6 7}$, was demanded. 
Damages to the cargo he estimated at $£_{1500}$ Pennsylvania currency, or $\$ 4000$. These damages, exclusive of interest on the value of the cargo while under detention, amounted to $£ 3250$, or $\$ 8600$.

The facts as to the capture of the Sally, the information asked for by the commissioners, and an urgent request to press the case of the Polly, in which an appeal had been taken to the Court of Appeals in London, were sent to Mr. Bayard. The Polly had been condemned because the Vice Admiralty Court at St. George held she came from a blockaded port. Guadeloupe, Girard asserted, and rightly, was not blockaded when the Polly sailed from Basseterre.

Mr. Bayard, early in 1798, was succeeded by Mr. Samuel Williams, from whom came word that the documents in the case of the Sally had been laid "before the referees and, as they appear to be such proofs as were ordered, I presume there will be an award in your favor.

"The Court of Appeals on the I2th instant (May) reversed the sentence in the case of your Brig Polly and Cargo and decreed them to be restored without costs or Damages, and ordered the captors to bring in $\mathrm{a} / \mathrm{c}$ of Sales and the proceeds. If we are obliged to seek for them at Bermuda, by the legal steps, two years may elapse before they are recovered. A memorial has been duly filed at the Board of Commissioners for full compensation." This, Girard protested to Williams, was unjust because the valuation of the cargo at Bermuda which the court seemed inclined to allow him had been made by interested parties. The Board of Commissioners was that appointed under the Seventh article of Jay's treaty.

At the time Girard wrote this letter Philadelphia was again afflicted by yellow fever and again its origin was hotly debated. The Academy of Medicine was certain it 
was of domestic origin and caused by the sultry weather, the pools of stagnant water in the streets and the foul air from the holds of ships. The College of Physicians was equally sure the fever was imported. One evening early in July an armed ship from Jérémie anchored off the Marine Hospital, passed ten days in quarantine, discharged her cargo at the Race Street wharf and then went up to Kensington. In a few weeks some fifteen persons who had been on or near the vessel were dead of yellow fever. During the first week in August fifty-three died. Again the people were panic stricken, and all who could, shut their doors and fled. Such was the exodus that in one square from which but twenty-five went in 1793 , one hundred and forty fled in 1798 . All employment ceased, the shops were shut, the market was deserted, the government offices were closed, the city tavern was closed, no ships came to the wharves, the banks removed to Germantown, and those who depended on their daily labor for their daily bread were brought to the verge of starvation, and once more the Guardians of the Poor and the Board of Health came to their relief. Tents and sheds were put up on the east bank of the Schuylkill River and twelve hundred destitute people were gathered near what is now Twentythird and Chestnut Streets. An urgent call for money, food, clothes, tents, boards, anything that could relieve the homeless, met with an immediate response. Provisions came in from New Jersey; money was subscribed in Baltimore; Philadelphians who had found a refuge in Germantown ordered $\$ 30,000$ to be raised in their name, and a second village of tents and huts soon rose at Master's Place near the Mill pond. Its streets were scrupulously clean and well policed. There were schools for the children and a huge bake-house and kitchen where food was prepared for the two thousand inhabitants. By the end of Septem- 
ber four-fifths of the residents of Philadelphia were believed to be in the tents and in nearby towns. The rest were urged by handbills posted on the walls and left on doorsteps, to flee. One hundred people, the handbill said, were stricken with the fever each day. Half that number died. Should the fever continue six weeks a quarter of the population of the city would be no more. "Why do you prefer famine, sickness, and death to health and plenty? Go! before it is too late." Three newspapers ceased to appear. A fourth went to Germantown, a fifth was reduced to a sheet one-half its usual size.

Deserted by its inhabitants the city fell a prey to gangs of thieves, who plundered the shops and houses and robbed the Bank of Pennsylvania. The convicts in the prison made several attempts to escape. Greatly alarmed at the robberies, nightly committed, the men of Southwark and Northern Liberties united for the maintenance of law and order and agreed, on the firing of a cannon, to hurry to the Potter's field, and there unite for action.

During these weeks of panic and confusion Girard, as usual, was conspicuous among the few who came to the relief of their fellow citizens and nursed the sick. To Hourquebie he wrote, in August: "Our doctors have, for the third time, lost their wits (Perdu leur Latin). They will presently assure us that the yellow fever is in our city. Surely these poor imbeciles have lost their minds. In spite of everything they have succeeded in frightening our citizens and causing an almost general flight. This state of affairs has caused a general stagnation of business."

Such had been the flight of business men that when Mr. James Douglas of Norfolk, wrote for a copy of the protests for non-acceptance of a note sent for collection, he was assured, "It is not in my power at present to send 
it to you, almost every one of our inhabitants have deserted the city. The public notary who does my business is in the country."

Paul Bentalou in his anxiety for the safety of Girard was "impatient to know what part you are to play this year in connection with this miserable bugbear of yellow fever. I think you would better not kill yourself with work again. Fatigue might in the end make you ill. If your philanthropy will not allow you to stay idle while looking on at suffering humanity, I entreat you do not let it extend to the Porcupines. Let all that miserable hord perish." The Porcupines were the Federalists, the readers of Peter Porcupine's Gazette, a violent anti-Republican sheet edited by Cobbett.

Bentalou was told, "I am still in the city and suffer cruelly from the conduct of our citizens who torture the unfortunates. I curse our ignorant physicians who are the cause of the epidemic and the great mortality each day.

"Five of my family have recently had the fever. Lemonade, barley-water, cammomile, some mild drugs and a little care put them all on their feet again. My housekeeper was one of them. She had a violent fever. As for myself I am well enough."

"I have not heard from you since the 28 th of last month," Bentalou wrote in September, "and feel uneasy. I must not conceal from you that I entertain serious apprehensions about your welfare. Twice you devoted yourself to the public cause and I trust in the present state of affairs you have had the prudence to excuse yourself for, judging by the accounts we receive daily, this is certainly a worse epidemic than that your city passed through in I793, and I repeat that the anxiety I feel for you is intolerable. I cannot help thinking that even if you are not 
engaged in some public function you nevertheless persist in remaining among the dead. Now, my dear Girard, your business must be so large that you are not obliged, as are many others, to contribute your presence. I beg you, if you have not already done so, set out as soon as possible and leave this modern Sodom."

"I beg you and reiterate my prayers in the name of the sincerest friendship, leave your business for a time, come here and allay my anxiety by your presence. I must tell you that a police ordinance, in force at present, cuts off communication between our city and yours. But if you travel by way of Lancaster, stay a few days, and then go on to Yorktown, you will find on that road a stage which will bring you hear, and if you can swear that you have not been in Philadelphia for fifteen days, there will be no difficulty about admitting you to our city."

After the dreadful days were past, Girard reported to his friend Dr. Deveze, then in Bordeaux: "Since you went away we have had a very severe epidemic. All our citizens left the city except the unfortunates who had no means with which to go. These believed they were in the grip of the yellow fever. Fear made them ill. Their relatives and friends abandoned them in their misery and left them to the care of doctors, who got rid of them very quickly and the result was the most frightful mortality. During all this excitement I remained in the city and, without mixing in politics, played a part that would make you laugh. Can you believe it, my dear friend, I visited as many as fifteen sick a day, and what will surprise you more I lost only one patient, an Irishman who indulged a little in drink. I do not suppose I cured one, nevertheless, you will agree with me that in my capacity as Physician of Philadelphia I have been very moderate and that no one of my confreres has killed less than I." 


\section{CHAPTER IX}

CAPTURE OF THE SALLY

Wrru the United States at war with France, and all trade with that country and her colonies cut off, Girard grew anxious for the fate of the Sally, which left the Isle of France in September 1798. So little did he expect she would escape the French cruisers that he wrote her captain :

"If you should be carried into a French port I desire you to apply to our consul, if there is any, and to write immediately to Mr. John Hourquebie, merchant at Bordeaux, advising him of every circumstance respecting your capture etc."

That the captain would ever receive the instructions was doubtful, and every day he scanned the commercial columns in the newspapers in hope of finding the announcement of the arrival of a vessel from the Isle of France. At last, early in January, 1799, Bentalou sent word of the arrival of one of his ships from the Isle of France and Girard wrote to him for news of the Sally.

"From what you tell me of her voyage she must have left the Isle of France about the first of October. If that is the case my brig Sally must have sailed for Hamburg before your vessel. Not having received my letters I suppose that your captain has not yet forwarded them. If you have occasion to write to him, ask him for news concerning the brig." When January ended and no letters came he said, "This circumstance added to the fact that it prevents my placing insurance on her, give me some anxiety."

In March he heard from Mr. Bickham that the Sally had sailed, and replied: "If the present intercourse law 
did not prevent citizens of the United States to send their vessels to French possessions I should have dispatched you my brig Liberty, but circumstances force me to postpone my opperations to your island. As soon as I am permitted to dispatch my vessels where I please I shall fix on a plan to carry on a regular trade to the Isle of France." Should the Sally return from Hamburg to the Isle of France she was not to be sent direct to Philadelphia but to Manilla, or to Java, and load with products of the Spanish or Dutch colonies and then start for home because it was not safe to come from a French port. "Our intercourse bill gives me great uneasiness. Some of our vessels with their cargoes have already been confiscated and sold by our Government for no other reason but the one of coming from a French port. This circumstance will point out to you the necessity of dispatching the Sally from a port which is not under the French government."

"Since writing you my last we have received the confirmation of the capture of the Insurgente French Frigate by the Constellation Frigate belonging to the United States commanded by Mr. Truxton. I hope this circumstance will not prevent an amicable settlement between France and the United States." April 3d he was still without news, and was wondering where she was when, on the

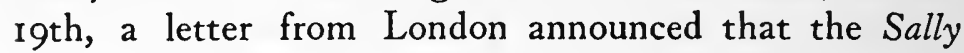
was in British hands.

"On the 20th ulto (December 20, 1798) your brig Sally, Captain Dorson," wrote George Barclay \& Co., "arrived at Cowes from the Isle of France after a passage of 96 days with a cargo of coffee, pepper, indigo, etc., on your account bound for Hamburg. Cap. Dorson put into Cowes in consequence of intelligence he had received from Cruizers in the Channel that France and America were at war and a few days after an officer from 
the Atlas, Man-of-War, was sent on board the Sally to detain her and make her undergo adjudication. The captain and crew, attended by our friend Mr. Auldjo, were examined and their depositions taken which, with the other papers, we have received and shall lay them before Council immediately. We are given to understand by our Proctor who has inspected the papers that there is nothing in them which will tend to effect your property and the Brig will be suffered to proceed. In the meantime the detention can be of but little consequence as the Elbe has been for sometime past completely frozen up." Much to their regret they soon found that the government was determined to proceed against the Sally. "We have, of course, taken every necessary step on our part and you may rely confidently on our doing everything we can towards bringing the matter to an issue both favorable and speedy."

Captain Dorson, in his report, added little. " Being informed by several Vessels in the Channel that France and America wair at warr I judgt it prudent to Put into Some British Port to get further information and accordingly put in here. But I am sorry to inform you that the day after my arrival here the Sally was taken possession of by an Officer and bots crew belonging to the Atlas man of War, on suspicion of the cargo being French or Duch Property. I have bean examined with my mate by the proper officers of the Admiralty at portsmouth and the Examination with all my papers were immediately sent off the High Court of Admiralty in London from whence I soon expected their return with restitution of my ship and cargo but contrary to my and everyone's opinion I this day Recev'd a Letter from Messrs. Geo. Barclay \& Co., your friends in London (to whom and Mr. Thomas 
Auldjo, American Consul, I have intrusted the management of the business), saying that the Captors by the advice of the King's advocate had Determined to proceed against ship and cargo."

Mr. Auldjo believed, "Ultimately the whole must be restored but there will arise loss considerable to you, no doubt by the detention, which is always unavoidable on such occasions. The very high price of coffee will, however, compensate amply to you. But in future I would recommend your bringing your goods to America before you send them to Europe, as much the safest and least troublesome way of carrying on the business for it is impossible for a vessel from any indirect places to escape thro the Channel without being examined and brought into port."

After a detention of three months the Sally was restored to her Captain, who, as in duty bound, entered a protest against her seizure, to the truth of which the mate and two seamen made oath before Thomas Auldjo, American Consul at Cowes.

Unable to dispatch a ship to any port in France or her colonies, his vessels were sent one by one to Europe and so it came about that in May the four vessels, Good Friends, Sally, Liberty and Voltaire, composing Girard's little fleet, were all at one time in the port of Hamburg.

They were soon scattered. The Voltaire went on to St. Petersburg; the Sally, her captain having failed to receive the orders of Girard, sailed for the Isle of France, and the Good Friends and Liberty came home in company. The value of the two cargoes was 54I,87I marks banco,which, at three marks banco to the dollar, amounted to $\$ 180,623.66$. The Voltaire returned from St. Petersburg in October and in November the three vessels were made ready for voyages to Havana. Two were well armed, and well manned; the three were to sail in company and were insured. 
"Be pleased," Girard wrote Mr. Ferrers, "to inform me at what premium you can have them and their cargoes Insured against all risks. Ship Good Friends, Caleb Earl master, armed with 20 guns, small arms and upwards of 50 men and boys, well fitted and sails fast. Brig Liberty Wm. Henderson, Master, armed with 20 guns ( 18 of which are mounted), completely manned and equipped having on board about 45 persons, sails fast. Ship Voltaire Ezra Bowen Master, without arms, Sails fast."

Command of the little fleet was given to Captain Earle of the Good Friends.

"My ship Good Friends under your command being loaded and ready and armed with Twenty carriage guns, well manned and in all respects equipped in a complete manner you are to proceed with her as soon as possible, in company with my brig Liberty Captain Henderson, also armed with twenty guns, to the port of Havana taking under the protection of your ship and brig Liberty, my ship Voltaire commanded by Ezra Bowen, which you will convoy all the way to the said port of Havana. Before leaving our River you are requested to plan and agree with Captain Henderson and Captain Bowen on the Signals which in your opinion will be easily executed, clearly seen and understood night and day so no separation of any one of my vessels can take place under pretence of ignorance, neglect or a bad look out."

"My intention in arming the ship Good Friends is to protect and defend my property from being captured by pirates or enemies of our country. This circumstance will point out to you the necessity of keeping yourself, as well as the Brig Liberty on the defensive and avoiding as much as possible to meet with or speak to any vessels. This may be effected by keeping a constant lookout up your mast, and more particularly by not trusting to colors, as often an enemy will disguise himself by hoisting the flag of a friendly nation." 
The supercargo for the little fleet was Mr. Alexander Dobignie, who was informed that the cargo of the Good Friends was valued at $\$ 176,190.98$; that of the Voltaire at $\$ 20,509.63$ and that of the Liberty at $\$ 134,55^{8} .56$. Wher enough was sold to buy return cargoes for the Liberty and $V$ oltaire they were to be loaded and sent home. Goods unsold were then to be put on board the Good Friends and taken to such unblockaded port as Dobignie thought proper, sacrificing, if necessary, goods to the value of $\$ 15,000$ "in order to close my business."

Havana was reached late in November, and from there Captain Bowen reported that in entering the harbor the Liberty ran on the rocks and damaged her rudder.

February I 800 was gone before the Good Friends with $\$ 40,087$ worth of produce and 21,000 "hard dollars," and the Liberty with $\$ 31,865$ in produce and 20,000 "hard dollars," set sail for home.

Girard had expected at least $\$ 90,000$ in specie, was greatly disappointed at the small sums brought by the ships and at once sent the Good Friends back to Havana; but the Liberty, without breaking bulk, went on to Amsterdam.

The value of the cargo of the Good Friends, Dobignie was told, was $\$ 37,967.72$. As the "principle object in dispatching you that ship is to bring back the funds which I have in your hands and to convoy my ship Voltaire all the way from Havana to this port I request that you will sell the ship Good Friends' cargo immediately after its arrival, particularly the provisions."

Again the supercargo could not comply with instructions and when the ships set sail from Havana, in May, the cargo of the Voltaire was valued at $\$ 54,468$ and that of the Good Friends at $\$ 35,173$. She also brought $\$ 24,750$ "in cash contained in twelve boxes and seven bags," 


\section{CAPTURE OF THE SALLY}

leaving a balance of $\$ 83, \mathrm{I} 29.5$ in the hands of Dobignie.

The Voltaire was the first to arrive and with sugar and logwood sailed for Hamburg, but the Good Friends went back to Havana. The Sally had fallen into British hands. From Hamburg she sailed for Batavia, left for home in February, I800, was captured by the British frigate Cleopatra and taken into Halifax. Girard knew nothing of this until August I5th, when Forsyth \& Co. of that city were written to and requested to take the necessary steps to secure her release, and Mr. Curwen was at once sent off as Girard's representative. He reached Halifax on the 26 th to find the trial set down for the $27^{\text {th }}$ and reported, "after hearing the case the Judge adjourned the court and is to give his decision to-morrow (August 29th)." On that day Forsyth, Smith \& Co. wrote: "We are extremely sorry to inform you that notwithstanding the clearness of the case of your brig Sally, and our having used every argument to convince the Judge that the property ought to be acquitted, he has thought proper to condemn vessel and cargo as French giving as a reason that as you are a natural born Frenchman, and still to trade with France you must be considered a Frenchman. This is strange doctrine and cannot possibly hold in England.

"An appeal has been entered and we shall give security to prosecute it to effect."

Mr. Curwen explained: "The reason of condemnation is this; that although you have lived in America since the year 1774, yet as you were born in France you cannot throw off your allegiance to that country, and he condemned the property as enemies, though he declared since he had no doubt but that the vessel and cargo belonged to you. I immediately entered an appeal. I have this morning made application to the agents to buy her on engaging to deposit the amount in the Bank of England, 
but they say they are not authorized to do it, unless the Captain of the Frigate should be here. It must consequently be appraised and sold."

"Should your judge," was Girard's reply to Forsyth, Smith \& Co., "have paid more attention to the Law of Nations and equity he should have restored my property.

"In regard to my citizenship no man can rate himself citizen of the United States longer than what I can. I resided here and in New York before, during and since our war with Great Britain. This is proved by the papers filed in your Court.

"Respecting the broad hint which your judge gives that I settled myself in this country in view to carry on trade with France only, if this was the case I should not have commenced my career in America by sailing out of New York as mate of a ship sailing under English colors to New Orleans."

To Bentalou, he wrote: "The disagreeable news which I have received concerning the condemnation of my brig Sally gives me much anxiety, not only concerning this vessel, on which I have only ten thousand gourdes insurance, on both ship and cargo, but also concerning the fate of the ventures now at sea. You will understand it when you hear the opinion given by the Judge at Halifax who, although it was proved I had lived in New York and Philadelphia since 1774, concluded his opinion by saying,

" "Girard being born in France and owing his allegiance to France, and having been engaged during some years in a course of trade with the Isle of France, a French colony, the Brig Sally and her cargo-the vessel having been so employed-is subject to confiscation.'

"After this judgment we can no longer count on our citizenship of the United States. That does not encourage me to continue my ventures as you may believe." 
October Ist Forsyth, Smith \& Co. sent their "account for money advanced, including the Court and Proctor's bills, together with our commission amounting in all to $\$ 1003.82 . "$

Girard now appealed to John Marshall, Secretary of State, recited the history of the capture of the Sally, enclosed a copy of the opinion of Judge Brenton, stated that an appeal would be taken to London, and asked that our Minister be instructed to lend his aid.

Marshall replied and sent a letter for Girard to forward to Rufus King which reads:

"You will much oblige me by giving to his case such attention as your situation will admit. Mr. Girard appears to have been born in France and to have removed to the United States in '74 where he has ever since resided and has carried on trade as a citizen of the United States.

"I perceive no pretext for considering this Gentleman as a Frenchman, and cannot doubt the reversal of the sentence of the Court of Vice Admiralty in Halifax."

The next letter from Mr. Curwen made known the results of his offer to buy the Sally and her cargo. "To these proposals which were verbal I received an immediate refusal, saying that they (the agents of the captors) had most positive and direct orders from Captain Pellew not to let the claimant get the property on any account, and by no means to make any compromise whatever, or on any conditions, but by all means to discharge the vessel. I must here observe that the Prize Act leaves it optional either with the captors or claimants by refusing a compromise to order a discharge. This being done I hurried the unloading as much as possible, but notwithstanding every exertion of mine they were about two weeks in finishing. The cargo was unloaded under the inspection

Vol. I-25 385 
of three appraisers, one appointed by the Court, one by the captors and one by myself.

"They made the following appraisement, viz:

Vessel..............8000 Drs.

Coffee at $9 d$ equal to 5 cents. (except a few bags which were damaged by the sweepings of the hold).

Sugar..............7 Dollars.

at which price it was tendered to the captors by the Register of the Court. They agreed to take it on going security that the amount should be restored immediately in case the Decree should be reversed by the Lords of Appeal. I immediately petitioned the Court praying that he would by no means suffer the property to be delivered to the captors on those terms, or at that valuation" and offering $\$ 9000$ for the Sally: I $d$ for the coffee and $\$ 91 / 2$ for the sugar. "This the Judge peremptorily refused and ordered a sale." When the sale came off the Sally brought $\$$ I I,680, the sugar $\$ 71 / 2$ and the coffee at $9 d$. and $91 / 4 d$. in "cash or approved bills at 30 days sight on London at par, and paid into the hands of Mr. Charles Morris the Register, to be by him placed in the Bank of England to the account of the brig Sally and cargo, until a final decision."

The loss on ship and cargo, some fifty thousand dollars, he accepted with his usual philosophy and did not hesitate to send the Liberty and Voltaire to Hamburg before the year closed. The Liberty carried a cargo worth $\$ 99,305$; that in the Voltaire was valued at $\$ 68,456$. From Hamburg she cleared for Calcutta with 160,000 Spanish milled dollars, and fifty pipes of French brandy for ballast.

The sale of the Sally at Halifax forced Girard to build another vessel. In November, accordingly, articles of agreement were drawn up with Isaac White, of Kensington, for a double decked ship seventy-two feet keel, twenty-seven feet beam, twelve feet hold and six feet 
between decks. The cost was to be "thirty-two dollars per ton Carpenters measurement." She was launched in the beginning of October 1801 .

At the close of the year 1800 three appeals were thus pending in London, - one for the condemnation of the brig Polly by the Vice Admiralty Court at St. George in 1794, one for the detention of the Sally at Kingston, and the third for the recent condemnation of another Sally at Halifax. Weary of the long delay attending the first and second, and determined to prosecute the third as vigorously as possible, Girard, in February I80I, dispatched Mr. Joseph Curwen to London with papers, documents and instructions bearing on all three appeals.

Great care was to be used in the choice of a lawyer. "Mr. Phineas Bond, the British Consul, will deliver you a letter for one of his professional friends which will perhaps be of some use to you. Nevertheless, it will be proper to inquire respecting his character before you employ him."”

"The greatest attention and activity will be requisite on your part to bring the trial of the appeal to a speedy issue. I have no doubt that the interference of our minister will accelerate the business. I beg that you will solicit his kind services so you may be able to put an end to the business trusted to your care."

His loss occasioned by the capture of the Polly was $\$ 23,947.94$; by the detention of the Sally $\$ 8666.67$; and by the condemnation of the second Sally at Halifax, $\$ 58,772$.

Mr. Curwen was provided with notes of introduction to George Barclay \& Co. of London, and to Mr. Samuel Williams, and the letter to Rufus King furnished by John Marshall, Secretary of State. With these, and his instructions, he sailed on the London Packet from New York in February I 801 . 
Scarcely was he gone when a letter came from James \& William Perot of Bermuda announcing that they had "received from Samuel Williams, Esq., Agent for Prize Causes, sundry monitions from the Court of Appeals relative to certain captures that were made in this Island for the purpose of demanding and receiving from the captors certain sums as particularized therein. Amongst them we find one in the case of your brig Polly, Captain Congdon, captured by John Robinson, of the Privateer Enterprise wherein Captain Robinson is Monished to pay the sum of $£ 2985,8.6$ Ster. within I 5 days after service of said Monition. Judging from causes of a similar nature that have come under our direction we have not any expectation that such will be now paid. We shall place that monition with Benjamin D. Harvey, Esq., Solicitor General, for the purpose of doing what is required by the Instructions that accompanied it. Should Captain Robinson not comply with the terms of the Monition we shall return it to Mr. Williams with the service endorsed on the back thereof that he may lay it before the Lords Commissioners whom it is likely will adopt the necessary measures to compel the payment thereof."

Girard made no reply until June, when he asked that the Monition be returned to London, that Mr. Curwen might take the matter in charge. He reached London in March, went at once to Mr. King, was told that the capture of the Sally had been mentioned to the Ministry; that nothing more could be done save petition the Lords of Appeal urging them to hear the case, and that, if they would not, it must wait its turn.

"Mr. Williams informs me that nothing whatever can be done in the cases of the Polly, Congdon, and the Sally. Cochran, until the commissioners appointed under the treaty resume their session. He says a Monition was 
sent by him last September to Bermuda. The captors have refused to pay. No other steps can be taken till the Monition is returned from thence. He says my personal attendance is entirely useless. You cannot imagine how much I am distressed on being told by everyone that any attentions of mine will be of no avail. Mr. King says there is no doubt but that the Sally, Dorson, will be restored; but the Time is very uncertain. $* * *$ If the case of the Sally, Dorson, is obliged to come on in turn, it will not be tried for a twelve Month. I should be sorry to remain here so long at a heavy Expense to you, and, after all to no Purpose. * * *. Mr. King informs me that in Consequence of the Condemnation of the Sally at Halifax and some other cases, that Court will be abolished. Pellew has been ordered home in Consequence of his Behaviour to Americans."

That nothing which might hasten the trial of the case of the Sally should be neglected, Mr. King, on March 6th, appealed to Lord Hawkesbury, Secretary for Foreign Affairs. The letter reads:

"My Lord:

"The Brigantine Sally, John Dorson Master, owned by Stephen Girard, a Citizen and Merchant of the United States, and laden with a valuable cargo, on her Voyage from Batavia to Philadelphia has been taken by His Majesty's Frigate Cleopatra, Isreal Pellew Commander, and condemned by the Vice-Admiralty Court at Halifax, because the owner was born in France, tho' he has been naturalized and Resident in America for more than Twenty Years.

"Mr. Girard has not only been long permanently settled at Philadelphia, where he has carried on Business as a Merchant or Trader, with different Countries, but has given the most indisputable Proofs of the Ties which unite him to the Place of his Residence: in 1793, when 
the Epidemic Fever desolated Philadelphia, which was deserted by almost every person who had the means of leaving it, Mr. Girard with a few others who might also have withdrawn, remained, and under the Denomination of a Board of Health administered Succor and Comfort to their distressed Fellow-Citizens, at the Peril of their own Lives.

"Not only the Cause assigned for the Condemnation of this Vessel and Cargo is unjust and vexatious, but the Circumstances and Manner in which the Property was disposed of was illegal and purposely calculated to impair the Remedy which the Claimant might expect by carrying his Case before the Tribunal of Appeals. The papers which accompany this Note are in every Respect so full that it would be superfluous to add any Reflections for the Purpose of demonstrating the Injustice and oppression of this Transaction. The case has been sent to me with Express orders from the President of the United States to lay the same before His Majesty's Government, and to call upon its Justice to take such Measure as shall afford immediate and Complete Redress to the Claimant.

"The ordinary Course of Appeals is attended with so much delay that I flatter myself in a Case so considerable in Property, and so strong in Right that an immediate examination of the Claim will be made and that the full value of the property with exemplary damages will be decreed to the claimant."

Lord Hawkesbury referred the letter to Mr. Nicholl, who replied, "the Sentence of the Vice Admiralty Court, supposing it to have passed upon the Grounds suggested in the Papers, appears to me to be erronious. But I apprehend that the proper Mode of seeking Relief against such a Sentence is by an Appeal to the Superior Tribunal, where it is to be presumed complete Justice may be obtained. 
"If the Complainant $* * *$ will immediately present his appeal, and it shall turn out that the National Character of Mr. Girard was the Sole Ground of Condemnation, it is probable that the Delay apprehended may be prevented by the Captor (under the Advice he may be expected to receive) abandoning the Sentence he has obtained, and consenting to the immediate Restitution of the Property."

"You will observe," was the comment of Mr. Curwen when sending to Girard a copy of this letter, "that he intimates the captor may be induced to relinquish the Property that has been condemned to him by the Court of Halifax, if, on perusing the Proceedings at Halifax, your citizenship should prove to be the sole cause of condemnation. That being the case beyond a doubt I yesterday, by advice of Mr. King, sent the Proceedings to Sir John Nicholl who no doubt will soon make his Report of which I shall advise you in due Time. Should the captor offer to give up the Property without further delay, or without a Trial before the Lords of Appeals, the question will then arise, whether we ought to accept or not? If we accept we cannot, of course, expect Damages or anything more than the Proceeds of Sales at Halifax-if we do not take the Property on such Terms we will be obliged to wait for trial in course and then run the risk of not receiving ample Damages and even not more than the Sales."

Unhappily "the agents for the Captors," Curwen wrote in June, "have declined doing anything out of the regular Routine, saying that they are not authorized by Pellew. This being the case it must necessarily be tried before the Lords."

In August, accordingly, the case was heard. "It gives me great pleasure, to be able to inform you that a Re- 
versal of the Sentence of the Sally, Dorson, was yesterday (August 12) obtained; not in so satisfactory a manner as I could have wished, but at the same time in a Way that was recommended by Mr. King, approved by the Council, and authorized by yourself.

"On the 5th instant a Memorial was laid before the Lords, stating the reason why the Sally had suffered Condemnation, etc. They ordered a Copy to be given to the King's Advocate and yesterday was appointed for Hearing. A few days before the Captors offered to let us have a Reversal of the Sentence provided, we would not contend for costs and damages, informing us at the same time that the Court would not sit after the I2th instant, and that there was a long Cause (previously ordered for that day) that would occupy the whole day. On Enquiry we found that every Thing was as had been represented. I kept our Counsel until after 3 o'clock at which time the other Cause was not half finished, consequently no chance of being heard this session, we judged it best to accept their offer which was to give us the neat Proceeds at Halifax and each pay their own Costs." Thus was the case settled and in October Mr. Curwen sailed for home.

At home during November and December Girard, in common with all his fellow citizens the country over, was deeply interested in the result of the Presidential election. In those days National Conventions for the nomination of candidates were unknown, nor were the parties organized as at present. By a caucus or meeting of Republican leaders Jefferson and Burr were recommended for the support of all true Republicans, and Adams and C. C. Pinckney were in like manner presented to the Federalists. Nor were the electoral colleges chosen as in our time. In some States Presidential Electors were chosen by the Legislatures; in some in Districts, and in others by a General Ticket. 
The choice of electors did not take place in all the States on the same day, but on such days as each State appointed. Nor was it as easy as at present to obtain returns. It was almost Christmas, therefore, before it was definitely known that Jefferson and Burr had each 73 votes, Adams 65, and Pinckney 64, and that the duty of electing a President fell on the House of Representatives, each State casting one vote.

The day for balloting in the House was the second Wednesday in February, 1801; but no choice was made on that day and a long and bitter struggle followed before Jefferson received the nine votes necessary to elect him.

Excited by the long struggle, thousands of men hurried to Washington, and among them was Bentalou, who sent Girard an account of what he saw. February II th he said:

"I take advantage of the opportunity offered by Mr. Duane to advise you that after many and repeated intrigues the Republicans have triumphed and the virtuous, the philosophic Jefferson is President of the United States. The first Aurora that you see after you receive this letter will give you the particulars that I have neither the time nor skill to describe to you. I will merely add that you may get your vessel ready for the Isle of France. It has been decided that the Intercourse Law will not be renewed, and as you know, it expires with the Presidency of Adams."

In this Bentalou, as he soon found, was mistaken, and on the 15 th wrote from Baltimore to "explain the enigma, and give you an account of the state of affairs until the time when I left Washington.

"Partly on business but much more from curiosity, or rather, I think I ought to say from patriotism, I arrived in Washington last Tuesday at 2 o'clock in the afternoon and was in time to see the end of the session preparatory 
to the great decision which ought to have been made the next day. Owing to the great crowds that had already arrived I was obliged to seek quarters in Georgetown 3 good miles from the capital.

"You may imagine with what eagerness I came to town the next morning early enough to have a conference with our representative before his duties called him to Congress, and although his assurances were not positive, I nevertheless hope for a satisfactory result. The preliminary arrangements you have no doubt read about in detail in your newspapers and you will have seen that the result of the certificates of election agrees perfectly with what had been foretold and that Jefferson and Burr were found to have an equal number of votes.

"While the certificates were being opened in the Senate chamber an Express, sent by the Republicans of this city arrived with orders to stay till the election was settled so as to bring the earliest news to the people of Baltimore. The first ballotings were rapid and all showed the same result, until at 5 o'clock in the evening when your State cast an unanimous vote for Jefferson which seemed to us a favorable omen. A considerable number of Republicans were in the Capital, the Speaker, the organ of the anti-Republican party, was no doubt intimidated, and on his own responsibility the Sargeant-atArms, at night fall, drove us out of the Capital. I was obliged to go three miles to my lodgings, and as I hoped that the vote would be finished during the night, in which case, according to Duane's arrangements the Baltimore messenger would leave at once, and go without stopping, as far as Philadelphia, I hurriedly wrote the letter in question and another to my wife, which I gave to the messenger, feeling sure that if the choice should not be made during the night I could get my letters again Thursday morn- 
ing. In the contrary case matters would be as I had told you, and I would have had the satisfaction of giving the news first to two people who are dear to me. But General Smith, being impatient and no doubt irritated by the conduct and obstinacy of the faction sent off the messenger at 4 o'clock in the morning to inform his constituents as to the state of affairs and I had the misfortune to find that my letters had gone without any hope of my being able to overtake them. Duane promised me that his son would tell you about this mistake and I hope it was not long before you were better informed.

"During the night of Wednesday and Thursday the House of Representatives took 26 ballots and, having resolved to stay in session until the choice was made and therefore being unable to adjourn, they found a new expedient and on Thursday at 8 o'clock in the morning they suspended balloting till I I o'clock. During the recess the two Morrises were closeted with the British chargé d'affaires!!!

"At I I o'clock the House met, took two ballots, and obtaining the same result took a recess till last Friday at II o'clock, and after two more ballots, making 30, without any change in the result, balloting was suspended until yesterday at II o'clock, and the result of to-day's balloting will not be publickly announced till to-morrow morning.

"Having told you the reasons that induced me to write the letter which I assure you has caused me a great deal of anxiety, as I feared you and your friends would not be warned in time and would therefore have prematurely congratulated yourselves on having obtained that salutory change so much desired by all true patriots. $* * *$

"The day before yesterday when the representatives 395 


\section{THE LIFE AND TIMES OF STEPHEN GIRARD}

left the session, indignation and irritation were visible on the face of the Republican members. Those from Pennsylvania and New York showed eagerness to find a safe means of communicating with their States at once, doubtless to sound the tocsin. Major Reinhard of your city undertook that duty and I that of accompanying him to this place. It was then 2 o'clock in the afternoon and the dispatches were not finished till three. The weather was frightfull; but neither snow, night, nor bad roads could keep us from starting, and at the risk of breaking some of our limbs, or the legs of our horses set out at once and arrived here at eleven o'clock at night. My first act was to rouse the printers in order to have them insert in their Gazette which was to come out yesterday morning, the information which I thought ought to be put before the public."

On February 17th Jefferson was elected and at eight o'clock that evening Bentalou wrote from Baltimore: "This time it is no mistake. Jefferson was elected today. General Smith's messenger has arrived this very moment and I hasten to send you word through the owner of the stage."

Girard had watched the coming political revolution with keen interest. As early as May he wrote his friend Deveze:

"Since you went awaȳ things have changed greatly. The men they call Democrats, and who are really true patriots and good republicans, are beginning to have some power. They make a strong appeal to the people by their doctrine of humanity, and of being the friends of the common people, which makes them dangerous. They had enough followers in the last election to elect Governors in four different states and now they have the courage to expect to elect a President in the coming election." 
This expectation was realized and his republican friends having appointed a committee to prepare for a noisy celebration on the fourth of March, Girard offered to give the powder. The offer was accepted, and

"At an adjourned meeting of the Committee of Arrangements at the house of James Kerr, February 20, I80I, Major Hugh Ferguson in the Chair, it was

"On Motion Resolved unanimously that the thanks of the Committee of Arrangements be presented to our republican fellow-citizen, Stephen Girard, for his patriotic offer of the Necessary supply of Gun Powder for the celebration of the $4^{\text {th }}$ of March next, an offer which the committee accepts with the more pleasure as coming from a citizen whose zeal is alwais manifest and distinguished on every humane and patriotic occasion."

"Let us hope," wrote Bentalou, "that the great efforts made by the Republicans will be rewarded by national prosperity, which I think we are justified in expecting from the administration of the best and most virtuous of men who said in reply to the congratulations offered him after the decision, 'It is a rule with me never to congratulate a young couple, at the time of their nuptials. I wish to wait one year to see how they come on, and if everything goes well, then congratulate them." "'

The ardor of his political feelings at this time led Girard to come to the relief of a sufferer in the cause of democracy. In I 798 Congress disgraced the Statutes of the United States by the passage of the "Sedition Act." Under it many editors of newspapers and writers of political pamphlets were indicted for seditious writing and not a few were tried and convicted. One of them was Thomas Cooper, who, in 1831 when President of South Carolina College, wrote Girard this letter:

"In the year 1800 on being released from prison where 397 
I had been confined under the Sedition Law, I was met by the letter-carrier who gave me a letter containing a draught on Abel Humphreys of Philadelphia at 2 months for 400 Dlrs. Mr. Israel Israel to whom I delivered it, told me that you had been so good as to give him the cash for it, adding that you refused to take any discount. That money, the amount of my fine, I paid immediately on receiving it from Israel Israel to Mr. Hall the Marshall of the district Court. Messrs. Humphreys, Israel \& Hall are all dead. I wrote to Mr. Serjeant, who procured Mr. Duane to make some search respecting it, by any entry in your books; none can be found.

"Pray do me the kindness to say whether you remember any thing of the favour you did me at that time. The money was paid over to Mr. Hall as my fine under a conviction for sedition for what was deemed by Messrs. Chase \& Peters, Judges, as libel on Mr. John Adams.

"Send your reply to this letter to The Honorable Warren Davis of the House of Representatives at Washington," by whom the letter was franked. Girard, in short, had paid Dr. Cooper's fine.

The display of partisanship and liberality, on the part of Girard, in paying for the powder, may have been stimulated by his own success at the polls. Again his name had been placed on the Republican ticket as a candidate for Select Council, and, carried along by the great republican wave of 1800 , he and his associates on the ticket were elected.

Our country was now once more at peace with France, for the Directoire had fallen from power. No sooner were the publication of the $\mathrm{X}, \mathrm{Y}, \mathrm{Z}$ dispatches, the action of Congress and the preparations for war known in Paris than Talleyrand denied that Messrs X, Y and Z were his agents, which was false, and demanded their names. The Ameri- 
can Envoys, he said, had been the dupes of unprincipled sharpers; no one had been authorized to call on them. Indeed, in his alarm, Talleyrand sent assurances to Mr. Murray that if another Minister were sent he should be received with the respect due a free and independent nation. Three more Envoys Extraordinary and Ministers Plenipotentiary, William Vans Murray, Oliver Ellsworth, the Chief Justice of the Supreme Court, and William Davie, were accordingly appointed, in February, 1799, and in October Ellsworth and Davie sailed for France. Murray, our Minister to the Netherlands, was at the Hague.

The new Envoys reached Paris in November, to find the Directory overthrown and the executive power in the hands of three consuls, of whom Napoleon was the first.

Instructions bade them make no treaty which did not provide for full indemnification for spoliations committed on the ships and property of American citizens; which did not create a board to hear and determine the claims of American citizens, and which did not bind France to pay the sums awarded. Not an article, not a line of either of the two treaties of $\mathrm{I} 778$, not a provision of the Consular Convention was to be embodied in the new treaty. No alliance was to be entered into, no guarantee of French possessions in America was to be given.

Unable to accept these terms the French ministers sent to Napoleon for instructions, and when his will was known, offered a renewal of the old treaties with indemnity in full, or a new treaty with no indemnity at all.

Neither of these would the Envoys accept. No treaty therefore was made; but instead a convention was signed on September 3oth, 1800 .

The second article set forth that the "two parties, not being able to agree, at present, respecting the treaty of Alliance of 6th of February, 1778, the treaty of Amity 
and Commerce of the same date, and the Convention of the 14th of November, 1788, nor upon the indemnities mutually due or claimed; the parties will negotiate further on these subjects at a convenient time."

This the Senate struck out, and the Convention, so amended, was ratified by Adams, February 3rd, I80I, and returned to Napoleon for his approval.

One month later, March fourth, with the close of the session of Congress, the act forbidding non-intercourse with France expired and the Good Friends was made ready for a voyage to the Isle of France.

The object of this voyage was stated by Girard in his instructions to Captain John Cochran.

"In the month of March, 1798, I despatched for that Island my brig Sally under the command of Captain John Dorson, with a cargo consisting of Sundry goods and specie consigned to the supercargo Mr. Martin Brickham, whom I directed to sell the goods composing the said cargo and to remit me the net proceeds thereof together with the specie he had on board, in Coffee and Indigo, by the return of said vessel and, in case he should judge more advantageous to my interests to stay himself at the Isle of France and to dispatch the Sally for Hamburg with produce of that Island, etc. consigned to Messrs. John Berenberg \& Co., Merchts, of that place, requesting them to sell the out cargo and to ship a return one agreeable to the list which he should send them (for that purpose) to do so. Circumstances having compelled $\mathrm{Mr}$. Bickham to adopt this latter plan at his arrival at the Isle of France, he dispatched the brig Sally for Hamburg and while that vessel was on her voyage, Congress passed the Intercourse Law which prohibited the citizens of the United States from having any commercial transactions with the French dominions. This alone has deprived me 
of any chance of getting back my property, but as the Intercourse Law is at present repealed, I flatter myself. that by your activity and attachment to my interest I will soon receive the property alluded to."

A voyage of three months brought the Good Friends safely to the Isle of France, whence she came home with a cargo worth $\$ 70,491.05$, of which $\$ 43,841.37$ was derived from the sale of the cargo of the Sally. On her return in December, without landing her cargo she was dispatched to Bordeaux and thence to the Isle of France or to Tranquebar.

"Wishing to render the present voyage as lucrative as circumstances will permit and being anxious to collect about thirty thousand dollars which I have in the hands of Mr. Martin Bickham at present at Tranquebar, or at the Isle of France, I have requested your consignees Messrs. Hourquebie Brothers, to ship at Bordeaux," so ran the instructions to Captain Cochran, "on board the ship Good Friends, Thirty thousand dollars in specie with a cargo of about twenty thousand dollars, ** suitable for the Danish, Dutch and French settlements in Africa or in the East Indies."

"If a peace between France and England is concluded, and American ships are permitted to proceed from Bordeaux to the Isle of France" the cargo and specie were to be consigned to Martin Bickham. "But in case the French Government would not permit your ship to clear out for the Isle of France, or that the war between France and England should exist," then the Good Friends was to clear for Tranquebar, to which place Mr. Bickham was to go should the war continue, "or Americans be excluded from trading with the Isle of France." The value of the cargo was $\$ 120,260.18$. 


\section{CHAPTER X}

TRADING WITH FRANCE AND RUSSIA

THE coup d'etat of the Igth Brumaire which established the consulate in France was followed at once by the drafting of a new Constitution and its promulgation on the fifteenth of December, 1799. Napoleon, who easily gained the mastery over his colleagues, set himself at once to make peace with the powers of the Coalition and December twenty-fifth addressed notes to Great Britain and Austria proposing that an end be put to the war. Great Britain rejected the offer, Austria did not accept, and in May, 1800, Napoleon made his famous crossing of the Great St. Bernard and descended on Italy. Marengo and Hohenlinden followed and in February, 180I, at Lunéville Austria made peace. Naples did the same in March; the other powers signed treaties during the year, and Great Britain, who for eight years had been at war with France, signed preliminary articles at London in October, I80I. The terms were discussed and finally settled at Amiens in 1802 .

In December, I80I, the United States Senate reratified the Convention of September, I800, which put an end to our war with France. As amended by the Senate, the Convention had been returned to Napoleon for his approval of the restriction which limited its duration to a period of eight years, and of the dropping of the second article which provided for a further consideration, some time in the future, of the question of damages for spoliations on our commerce. Determined to pay no damages, Napoleon saw in this action of the Senate a chance to be rid of a troublesome issue, and in giving his approval added the words that he did "accept, ratify and affirm the above 
convention, with the addition imparting that this convention shall be in force for the space of eight years, and with the retrenchment of the second article; Provided that by this retrenchment the two States renounce the respective claims which are the object of the said article."

This the Senate approved in December 180r, and by so doing released France from all liability for the spoliations committed, by her ships, courts and privateers, on American merchants prior to September $30 t h$, I 800 .

That the Federal Government by this act became responsible for the spoliations seemed to our despoiled and plundered citizens beyond question and in city after city they met to consider what steps should be taken to secure relief. Those living in Philadelphia gathered, on the fourth of January, in the City Tavern, put Joseph Bok in the chair, and appointed a Committee of Seven "to draft a memorial to Congress on the subject of indemnification for French Spoliations and to correspond with such other Committees in the United States as may be appointed." The Committee was to report within twenty days. Girard was one of the seven who drew up the memorial, which was left at the office of the Insurance Company of Pennsylvania for signatures by the sufferers.

The ports of Western Europe having been once more opened, by the general peace, to trade and commerce, the former correspondents of Girard made haste to inform him, and solicit consignments as of old. Said one in Bordeaux:

"It is the 21st Vendémiaire year 1o (October 13, 1801). I have the pleasure to inform you that the preliminaries of peace between England and France was signed on the gth Vendémiaire. The ratification of a general peace is impatiently expected, and as soon as it becomes gener403 


\section{THE LIFE AND TIMES OF STEPHEN GIRARD}

ally known, it will prove a universal boon, by bringing commerce out of the stagnation in which it has been paralyzed such a long time. I therefore hope that before long we shall be able, with safety, to enter into business relations with you, which will prove reciprocally profitable."

A Rotterdam firm wrote: "We think it a duty encumbent on us to embrace this first moment to acquaint you with the pleasing news of the Preliminaries of Peace being signed between the King of England and the French Republic. ${ }^{* * *}$ We do not doubt but you will rejoice with us on this occasion, the more so while it gives us a well founded hope that it will be conclusive to a peace for which humanity longs.

"We are unable for the present to mention what effects this news will produce on the Prices of our Market."

Hourquebie frères at Bordeaux reported: "A messenger has.just arrived from Paris with the news that the Preliminaries of Peace with England have just been signed. $* * *$ We have no time to give you any details about the state of business, but do not believe this market will be unfavorably affected by the question of peace. We enclose a price list, but you cannot depend on it any more. From news just received from Hamburg it appears that the business outlook in that city is most discouraging. We hope you will not be affected by the failures likely to result."

"It is now the roth of October and the news of the preliminaries of peace has been confirmed and is now absolutely certain. England is to restore all her conquests except the Island of Ceylon and the Island of Trinity, which she keeps. Egypt is to be evacuated and given back to the Ottoman Porte; the Island of Malta to the Knights of that Order; the Cape of Good Hope is to be 
held in common by the high contracting parties. All other possessions on land or sea are to become the property of the nations that owned them before the war. After the shedding of so much blood there is practically no difference in the final result."

Prevost wrote from Hamburg: "The great and interesting news we received a few days ago of the preliminaries of Peace between Great Britain and France being signed on the Ist of this month has dispersed in most of our merchants the last hopes of seeing West India Produce rise again to their former value and some of them, particularly those who received the news by an express sold their stock at any price and threw them down all most as low as they had been before the beginning of war. They soon found reason to repent their ill calculated measures, for, after the arrival of the English mail by which we learned that Colonial articles instead of falling had kept up their prices, ${ }^{*} *$ our prices rose."

To Girard the state of the markets at home and abroad as affected by the news of the peace of Amiens, was a matter of much concern. The Good Friends was then on her way to Bordeaux, the Voltaire on her way home, the Liberty at the wharf waiting to be changed to a three master, and a new vessel, the Rousseau, had just been launched. She was described by Girard as "of the dimensions of the Voltaire," and intended for the Isle of France "or some other port in India."

The launch was followed by the usual dinner to the ship carpenters, which, as the bill shows, cost $\$ 55.47$.

It was late in January, 1802, when the Good Friends reached Bordeaux, and Hourquebie frères wrote:

"To tell you that after an interview between our Mr. John and the Receiver of Customs at the Custom House, we hope to have the duties on the Coffee brought by 
your ship Good Friends, refunded. This duty may amount to about 6000 francs. Our claim was based on the following considerations: I. It will have to be proved that the ship Good Friends imported into the Isle of France, wine, oil and other articles of French production. 2. That the coffee which the vessel brought back represents the proceeds of the imported articles, and is a product of the French colonies. You will therefore have to obtain a certificate from the French consul in Philadelphia stating that your vessel left such and such a day with such and such merchandise, and arrived on such and such a day on her return voyage, at Philadelphia, from the Isle of France with a cargo of colonial goods, products of the French colonies. In addition to these documents there must be a certificate of origin to prove that the coffee, sugar and indigo were products of the the Isle of France *** We shall also need a sworn statement to prove that your vessel left Philadelphia for the purpose of importing the above mentioned goods into the port of Bordeaux.

"This is about what we need in the way of documents. You may depend on it that we shall take all necessary steps to insure the success of this business. No pains will be spared by us. It will be most important to grease the hand of the person who is to attend to this for us, provided he will grant the above mentioned reimbursement. * * *

"We have this moment received a letter from our friend M. Millot, who tells us he took legal advice about your old claims against the government, and the opinion was that the matter must be laid before the Prize Court in Paris, and that you cannot fail to win your case; but to begin with it will cost you a first outlay, for various formalities, of about 1200 francs."

"I approve the measures you are taking to obtain 406 
a rebate of part of the duties levied on the cargo of the ship Good Friends. The certificates you ask for are enclosed," was the prompt reply. "I thought it better to get them direct from the Custom House as the consul, or commissioner of the Republic of France, does not keep any register of cargoes entering or going out from this port ** I therefore have merely had them legalized by the consul, and hope they will be found correct and that you will be able to settle this affair at once to my advantage without being forced to wait for those you expect from the Isle of France. Do not forget the douceurs usually paid on such occasions; make them very large if you find it necessary. Finally, strike while the iron is hot. If those who had charge of my funds had followed this rule my funds would have been collected long ago."

A protest was accordingly made to the Minister of Finance at Paris, who, in April, wrote to Hourquebie frères: "I have received the petition in which you ask exemption from the duties on the cargo of the American ship Good Friends which you say sailed from Philadelphia to the Isle of France and put in at the port from which she sailed in order to avoid English cruisers.

"I must inform you that you would have no claim to such an indemnity unless the Good Friends had returned directly from the Isle of France to Bordeaux, with certificates of origin furnished by the authorities of the colony. Such a direct return is indispensable by Art. I 4 of the law of the 3 rd Frimaire year 5; hence the fact that the Good Friends put in at Philadelphia and remained at that port almost a month is enough to destroy any claim to have the cargo exempt from duty. Finally, by the terms of Art. 14, of the Indian Tariff of March 15, I79I, and Art. I7 of the law of July 6, I79I, goods 
not accompanied by a certificate of origin are subject to the same treatment as merchandise imported from abroad."

In the letter from Hourquebie frères, enclosing this reply, mention was made of "The disastrous news which we have received from San Domingo."

The course of events in San Domingo since the August day 1797 when Toussaint forced Sonthonax to leave for France, need not be followed in detail. It is not necessary to tell how Toussaint drove off the new Commissioner sent by the Directoire to pacify the colonist; how he forced the English to evacuate the towns and seaports they held; how he made war on the mulatto General Rigaud; how he defied the three Commissioners sent by Napoleon; how he took possession of Spanish San Domingo and made himself supreme over all the Island.

That a day of reckoning would come the moment Napoleon was free to act was certain. The signing of the preliminaries of peace with Great Britain, October I, I80I, left Napoleon free to act and almost immediately an expedition against Toussaint was made ready in the ports of France and Spain. The commander of the army was General Leclerc, who, December $\mathrm{r}_{4}$ th, with a part of the army and fleet set sail from Brest, and February $3 \mathrm{~d}$ arrived before Le Cap, defended by the black General Christophe. A storm prevented an entrance, the fleet put out to sea, and two days later, when it returned the blacks had fled and Le Cap was in flames.

An account of what had happened on the Island had already come to Girard from another source. In September, r8or, he had taken an interest in the ship Fanny and her cargo, worth $\$ 43,036$, sent to Bordeaux by Robert Bethell \& Son. This he was led to do, he wrote Hourquebie frères, because of his "friendship" for Mr. Robert 
Bethell, Jr. and "my old acquaintance with his father." From Bordeaux the Fanny went on to the West Indies. At St. Thomas her captain reported: "I arrived off St. Pierre Martinique 30 th ulto. after a passage of 25 days from Cardovan. was not permitted to land. the Commandant sent off verbal orders for my Immediate departure under penalty of being Fired at from the Fort, in consequence I bore away for this place where I arrived yesterday and tho I have made every effort Cannot find any Purchasers. I have advis'd with Messrs. Murphy \& Sauffrain, and others, the best informed merchants in the place, not one of them but says were they in my situation at this moment they would be at a loss what to do as the state of affairs are very uncertain in Hispaniola for if Touissaint should oppose the troops of France (who were seen a few days ago to winward of the Cape) it is thought property will be very unsafe in that Island, but as it is Impossible to do anything here I must try elsewhere and Intend to sail tomorrow morning and proceed off the Cape for advice only."

Thither accordingly he went and "on the I2th (of February) appeared off Le Cap, saw the fleet lying in there, stood off and on close in for two hours with a signal flying for a pilot, and none appearing, I Bore up for Port Republican. next day $\mathrm{r}^{\text {th }}$ thas boarded by men from a small schooner off the mole stationed there to caution vessels going into the Mole or up the Bite. Informed that Le Cap, Fort Daughpin and Port Paix was Burned, that the Blacks burned or Confiscated everything that came into their hands. Informed a squadron had gone up to Port Republican-a few hours after was bro't too by the National schooner trois Couleurs the Captain of which advis'd my going back to ye Cape."

This he did and "found everything in confusion, up409 


\section{THE LIFE AND TIMES OF STEPHEN GIRARD}

wards of Nine tenths of the City destroy'd no business doing, the general putting everything the Fleet and Army wants in Requisition. Prices and terms of payment all his own."

Not everything was taken. For such as was, Girard, in May, received two bills of Exchange, one for 30,000 and one for 29,159 francs, drawn by General Leclerc on General Willeminot paymaster general. These he promptly sent to Joseph Curwen, and told him, "Should you meet with difficulties in obtaining payment and should you judge prudent to give something in view to facilitate the recovery of the Bills in question I leave it to your option to act for the best and to give such douceur as you will think necessary."

Mr. Curwen, in April, had sailed for Bordeaux in the Voltaire charged with many matters of importance. One of them was the collection of the old French debts. "Should you," wrote Girard in his instructions, "have the good fortune to come upon terms of negotiating a settlement I recommend you to insist on the whole payment but not to miss a final settlement even on their own terms. I wish to impress your mind that I shall not regret any sacrifice which you will make for the closure of that business.

"I am informed that those who have claims against the French Republic are obliged to use all the intrigues imaginable. In view to obtain their payment I recommend you to use all the stratagem which the case will require even to give money if you judge it necessary."

Yet another to be settled was that against "M Samatan of Marseilles who was executed during the French revolution; but as I am informed his property was given up to his Widow agreeable to M. Millot's letter, she alone is accountable to me, please attend to that business." 


\section{TRADING WITH FRANCE AND RUSSIA}

Mr. Curwen was further instructed to close the business relations between Girard and Hourquebie Brothers "who I have reason to charge with negligence."

On the Voltaire was a cargo worth $\$ 248,042.84$ consigned to Mr. Leopold Nottnagel, a passenger, and destined for such port as he thought proper.

"Immediately after your arrival at that port," wrote Girard in his instructions, "I request that you will take the necessary steps for the landing and preparing the sales of the ship Voltaire's cargo which I desire to have effected by auction (except the sugar, coffee and Pepper which may be sold at private sale). Consequently it will be necessary to have a sufficient number of printed catalogues or Bulletins which must be distributed in all the places, cities and villages from where purchasers may be expected. The sales must be guaranteed by the house on whom you will prevail yourself and the whole conducted in the same manner as the European East India Comp'y does."

"I request that you will lose no time in dispatching the ship Voltaire back to this port with ballast and Sixty Thousand Spanish milled Dollars." The rest of the proceeds of the cargo was to go to Messrs. George Barclay \& Co. in London.

May 2d, 1802, Antwerp was reached, from which city Mr. Curwen wrote: "The Voltaire is the largest ship that has been in the Scheldt for fifty years: all descriptions of people visit her: The Préfet was on board yesterday: and the General in Chief will go today." When the Voltaire set forth on her return voyage toward the end of June she carried 140 tons of coal and 36,000 piastres, costing in all 97,139 francs 17 centimes. The net proceeds of sale of the cargo amounted to 676,666 francs.

Since his arrival at Paris, in May, Mr. Curwen had 411 
been busy with the old French claims. "Your clàim," he wrote, "naturally divides itself into five different Heads or Branches: it has been recommended and I think with Reason, that I should make as many applications so that a good claim, or one that will be immediately liquidated, may not be retarded by a doubtful one.

" Ist. The Brig Kitty condemned at Guadeloupe. This Case must be regularly tried before the Tribunal of Prizes: a reversal of the Sentence by Collot must take place before any application can be made to Government for a Restitution of the Loss sustained: the Papers have been in the hands of an eminent lawyer for an Opinion which I have in my possession, it is favorable: he tells me some papers are wanting for which he has written to Guadeloupe about three months ago, he cannot bring on the trial without them. Should the Sentence be reversed there is some doubt whether the Treaty does exclude you from Indemnification from this Government. Mr. Livingston thinks it doubtful.

" 2 d. The Demurrage of the Good Friends at Bordeaux and the Kensington at Morlaix. Mr. Livingston is now in correspondence with the Government on the subject. The French Government contends that by the $2 \mathrm{~d}$ Article of the treaty all losses occasioned by Embargoes are excluded from Indemnification; this remains for the Government to settle.

" 3 d. The Bills of Exchange on the Marine Department. I am informed that this is a good debt and will be paid. The first step to be taken is to have them liquidated in the Bureau de Comptabilité Intermédiaire, who give a Receipt by which the debt is acknowledged. The Mode of paying those Debts is not yet settled: but there is not much doubt they will be settled some way soon, most probably funded at $5 \%$. 
"4. The Loss sustained by taking the schooner Nancy's cargo at Guadeloupe. Some of a similar nature have passed the Bureau de Comptabilité Intermédiaire and have been placed upon the same footing as Bills of Exchange. I shall make immediate application for this as well as the others: it is probable they will dock it considerably should they even admit the Principle.

" 5 th. Le Tombe's Bill for Livre, I6,537,10; of this 9000 Livres have been received by Bizouard \& Millot and accounted for to Messrs. Hourquebie. A Law passed in the year 5 placing all debts subsequent to that Period upon the Grand Livre at 3\%. they have offered to me to do the same with this. Mr. Livingston says ourTreaty does away with any Law upon the subject and that they are bound to pay it as the old debts in arrears, and that it would be wrong to accept of their Proposition. I shall endeavor to have it liquidated by the same board as the others."

A careful examination of the documents relating to the claims showed that Mr. Curwen "had only received from Mr. Millot the certified copies of the Bills of Exchange. Every inquiry has been made for them in the Marine office and elsewhere and at last I find by a certificate of Mr. Randolph, formerly Secretary of State, that they were deposited in that office in 1795 where they are no doubt still remaining. The Nine Bills of Exchange as well as the five were regularly enregistered in the Office of Marine and those are the only ones they will pay. I mean those they have marked. The ordinance of Genet has never been presented here, but must be sent with the others. I have to request you will lose no time in procuring and forwarding them to me by the first vessel to any Port in France. To prevent any future Difficulties it would be advisable to have them endorsed by the 


\section{THE LIFE AND TIMES OF STEPHEN GIRARD}

French Consul at Philadelphia and put on Board by him, and also for him to take a note of same together with his Certificates of his having so forwarded them which you will send me by the next opportunity. I cannot express my astonishment that Millot never pointed this out to you; it proves that he never knew anything about your Claims. These and the 150 barrels of Flour are the only Parts of your Claim that I can give you any hopes of; they are certainly worth 50 to $60 \%$. The others are generally excluded by the Treaty, or by the construction they put upon the $2 \mathrm{~d}$ Article or the word Indemnity which they say extends to all Cases of Demurrage occasioned by Embargoes or otherwise. This will do away all Claims for the Good Friends embargoed at Bordeaux; $* * *$ and I fear the Kitty condemned (although most unjustly) at Guadeloupe comes decidedly within the treaty. I propose on my return here (Paris) to write to Mr. Livingston on that subject.

"The Nancy at Guadeloupe is the worst documented claim of any: in order to do anything it would be necessary to prove that the Price paid by the Administration of Guadeloupe was $40 \%$ below what it could have been sold for: there is nothing but the Captain's opinion on the subject, which he has sworn to, which will not, unsupported by any other Proof be considered as Evidence. You have no certificates of the Quality of the sugar or that a cargo of sugar, coffee and cotton would have yielded a profit of $25 \%$ more than a cargo of sugar only. $* * *$

"Thus you see the late Treaty strikes out by far the greater Part of your Claim for Indemnification from this Government but you must have recourse to that government whose acts have thus prevented you from Recovery here. As you gave them notice of your hopes in the most formal Manner in I795 you are particularly entitled to consideration." 
On receipt of this letter, late in September, Girard at once wrote to Madison: "Mr. Joseph Curwen *** writes me from Paris that he wants fourteen Bills of Exchange drawn by the Administration of the French Colonies on the Treasurer of France or on the Minister of Marine, also a delegation drawn by Mr. Sonthonax on Mr. Genet, Minister Plenipotentiary of France to the U. S. of America. As those Documents are enclosed in a Bundle containing sundry vouchers relative to my claim against the French Government which I have deposited in the Secretary of State's office in the Year 1795, I beg as a particular favour that you will be so good as to have said fourteen Bills of Exchange and Mr. Sonthonax's Delegation selected and forwarded to me as soon as will be convenient."

After waiting a month without a word from Madison, Mr. Robert Bethell, Jr., was dispatched to Washington as bearer of another letter to the Secretary. He was unable to get the bills; but they were soon sent by the chief clerk and duly forwarded to Mr. Curwen. They consisted of nine original Bills of Exchange for 48,66I livres, 17 sous, 8 deniers tournois; the Delegation drawn by Sonthonax on Genet for 20,74I livres, 5 sous "Hispaniola currency," and "the copys of five Bills of Exchange amounting to I7,753 livres, 13 sous and 4 deniers tournois the original of which I have sent to Mr. Joseph Fenwick, Esq., American consul at Bordeaux."

Meantime Curwen wrote from Bordeaux late in November: "I have left all your business with this Government in the hands of Mr. Thomas Melvill, Jr., an American banker. ${ }^{* * *} \mathrm{I}$ am also to send him the Bills of Exchange when they arrive. Nothing has been done for the Payment of the liquidated debts; there will soon in all probability. As it has become a general thing, my remaining at Paris became altogether unnecessary the 


\section{THE LIFE AND TIMES OF STEPHEN GIRARD}

more particularly as I thought I could be of more service at Bordeaux or Marseilles. I left the Bill of Leclerc's in Mr. Melvill's hands with directions to remit the Proceeds to London for your account to Messrs. George Barclay \& Co. I also directed him to remit any other monies he may receive on your account in the same way. Leclerc's Bill became due yesterday: there is no doubt but it is paid deducting 3 per cent.

"About ten days before I left Paris I made an Agreement with a Person of the Name of Souffes who is employed in the Marine, for the Liquidation of the Embargo of the Good Friends at Bordeaux and the Kensington at Morlaix as well as the Capture of the Kitty at Guadeloupe. You will recollect that my last informs you all these were considered as done away by the treaty. Soon after I wrote to the Minister of Marine demanding Payment of these Debts. This Person (Souffes) whose duty it was to answer the Letter said he would engage to get them all liquidated if I would let him peruse the Documents. He did so, returned them and persisted that they ought and would be liquidated. I immediately offered him Ten p. Cent on the Amount payable in liquidated Paper or out of the Proceeds when recovered. He is not to have a Sol if he does not succeed. He seems very confidant of his Success. There can be no harm in trying." The Good Friends, which reached Bordeaux in January, sailed March first with a cargo invoiced at 301,600 francs. As the French Government would not permit her to clear for the Isle of France she sailed for Tranquebar. Nevertheless Captain Cochran made his way to the Isle of France, which he reached in June to find, "that the cargo will not fetch within seven thousand dollars of the first cost if sold altogether altho the cargo has turned out in condition and quality supurour to annay from 
france. but I am in hops from Mr. Bickham's attention to your interests he will be able to relise the first cost which is dowing wonders as theire is about Twenty French and American ships now in port and all the french ships with Cargoes much the same as our owen." Mr. Bickham wrote, "it is with regret I say she has come to a very bad market, however, as I shall put the cargo in store and I intend retailing it out, I hope to be able to get first cost."

"The situation of this Island is so convenient for trade, and its port so commodious that there will be doubtless a great deal of good business done here. It can be looked upon in a manner, as the Store house of the Eastern world; there are a few places where a more General assortment can be found and It exceeds all places I ever knew for activity in Business; a great deal is done on credit and in exchange of goods for goods; it is a trifling circumstance for a merchant of Reputation to have out Bills to the amount of 150 to 200,000 Dollars. - this Island, according to the last letter from the Minister of Marine and the colonies, will enjoy all its former privileges and consequently will remain free to all nations; therefore should the Americans be excluded from trading to the English and Dutch settlements in India (as our Treaty with Great Britain expires two years after the peace I think it likely they will endeavour to Cramp as much as possible in our Trade) this will become a place of great recourse to them and they will, I imagine, carry on extensive trade here. $* * *$ therefore I propose to you anew to take a Concern with me, at this place and establish a person of confidence, at the principal french settlements in India; by that means two vessels might be Constantly employed to great advantage and we could engross the greatest part of the trade with our Credit in addition to

Vol. I-27 417 


\section{THE LIFE AND TIMES OF STEPHEN GIRARD}

the Capital we should have for I am told that very liberal credits can be procured in India, frequently for one and two years."

Philadelphia during the summer of 1802 was again visited by Yellow Fever.

Early in June a vessel called the San Domingo Packet reached the Lazaretto, was detained there twenty-one days and towards the close of the month came up to the Vine Street wharf. A week later a carpenter, working on a ship near by, was taken down with yellow fever and died, and in less than ten days eight others met the same fate. This led the Aurora to declare that it was certain a fever as virulent as that of '93,' 97 ,' '99 had broken out at Vine Street near the San Domingo Packet, and to demand that the sick be instantly removed from the well.

Thereupon the Board of Health made a visit to Northern Liberties, reported that all the sick had been removed and forbade all communication with the infected district. During a few days no new cases were detected and the Board announced that the fever had subsided; but July had not ended when the Aurora asserted that nineteen cases had appeared in the Northern Liberties, accused the Board of keeping the new outbreak quiet, and again demanded the removal of the sick from the well. Once more the Board visited the infected region, bounded by Vine, Callowhill, Front and Water Streets, reported they found but four persons sick with fever of a malignant kind, and assured the citizens that the rumors were greatly exaggerated and that notes had been left at the houses in the infected district recommending families to remove to the country as the best way to stop the spread of the fever. If they had "no retreat," the Board would endeavor to find one.

The fever soon spread to the city, whereupon the 418 
Aurora cried out that since the sick were not removed from the well, the well must remove themselves. The Board admitted that the fever was "very malignant" and entreated all who could to leave at once. The Editor of the Aurora then published an address to his "Fellow Citizens," told them there was "no remedy but in flight or frost," and announced the removal of his newspaper to Frankford.

Flight now became general. So many went that Councils authorized the Mayor to establish nightly patrols to protect property, and to borrow $\$ 15,000$ from the Banks because so many people had gone, and were going, that it would be impossible to collect taxes.

The conduct of Duane, the editor of the Aurora, so exasperated Girard that, about the middle of August, he withdrew his subscription. "The part," he wrote, "which you have taken to alarm our city and to ruin the most valuable class of our Citizens has rendered the Aurora very dissagreeable to me, therefore I have resolved to postpone taking the paper alluded to while it is conducted by its present Editor. To this I have to add that about one year ago I lent you Two hundred Dollars without interest or security. For this I have received your notes payable at one or two years. As one of those Notes is due some time past and that I have sent several times to you without being able to receive payment I have to request that you will send me the money, otherwise I shall put sd note in the hands of my attory."

"Your letter of yesterday," was the reply of Duane, "I received this instant. It has given me sincere pain that you should be capable of writing or dictating such a letter and it grieves me that it is not in my power to extricate myself from the obligation which I am under to you who are actuated by passions so ungenerous as your letter manifests. 


\section{THE LIFE AND TIMES OF STEPHEN GIRARD}

"Tho I am your debtor for money and favor, I am not obligated to submit to your errors or prejudices. The first note passed to you by me was at interest and you deducted the interest in advance giving me only the balance after deduction. Your second loan of 100 dollars was without interest and is yet unpaid. The former I thought had been paid, but in this I may be mistaken as I cannot approach my books at this place (Mr. Duane had gone to Frankford). What I owe you shall be paid as soon as I possibly can. But you should not hesitate to gratify your resentment on my account. You will gratify a great many, but it will neither injure my credit nor serve your reputation.

"The motives which you assign for your conduct are not less extraordinary than the spirit of your letter. You withdraw your subscription while I am Editor of the Aurora and menace me with a law suit 'for the part I have taken in alarming the city.' I sincerely regret that you should be capable of assigning such a cause for such conduct. In the eyes of thousands the part I have taken is considered humane and meritorious. Many are of opinion that the part I have taken will be the means of saving hundreds of the lives of the most valuable class of citizens, parents to their children, wives and husbands to each other and to their kindred and friends. These, to be sure, may be matters of opinion, but if they should be matters of fact, Whether ought I to console myself on the part I have taken in saving so many lives or lament at losing your subscription?

"Perhaps you considered that the lending me 200 dollars ought to have silenced my private judgment, that it discharged me from the moral duties which I owe the public and owe my own family. But Sir, my conduct is not regulated by a pecuniary standard, moral 
obligation weighs heavier with me than dollars. Domestic happiness is my riches-the approbation of my conscience is my luxury.

"The conservation of families and the diminution of social affliction may not enter into your calculations. Your body fortified against contagion and your mind indifferent to miseries you do not feel, may find a justification of your own conduct in remaining in the city. But those who have tasted of the terrible affliction and watched with momentary anguish its desolating march thro families and cities ought at least to be indulged if they sincerely strive to save others from evils which they have themselves experienced.

"To a Merchant the delay of a voyage is no doubt an unpleasant occurrence, it is not agreeable to active enterprise to see its capital inert, its circulation as it were stopped. But to me the death of one of my family would be a much more serious affliction than the loss of twenty such ships as you send to sea (if I possessed such). The loss of a voyage is a great grief to a merchant. Thank God, I cannot enter into the temper of feeling which puts merchandise in competition with the affections of a father, a husband and a man.

"As to the paper, while I am Editor you shall not have it. but do not mistake the value of this mighty mark of indignation. After paying for paper, workmen, etc., and delivering you 313 papers in a year,-the whole of my profit out of your eight dollars is the mighty sum of six cents for one year! This being the sole reward for my personal labor and the price for which I am to be the sport of Knaves and fools, I shall cheerfully return to you for the whole period that you have subscribed to my paper, and while I lament the error into which no generous passion has led you, I must console myself with 
the gratification that I have acted as I conceived was my duty to myself, my family and the public, disregardfull of personal pecuniary interest or the selfish policy of a part of mankind."

A postscript stated "Should your conduct towards me after this be governed by the same temper as your letter, I shall deem it my duty to lay both before the public."

"Your statement respecting the money which I have lent you," was Girard's reply, "is not correct, on the $3 \mathbf{I}$ December 1800 I discounted your note of that date for $\$ 200$ payb in 12 months. This note was paid into the Bank of Pennsylvania. On the $2 \mathrm{~d}$ July $180 \mathrm{I}$ I lent you through the hands of one of your friends 200 Dollars and rec'd your notes payb at I \& 2 years for $\$ 100$. Each one of those notes is due and in my possession, the other is deposited in the Bank of the United States. In regard to the Interest I shall charge none and will be glad to receive the principal without further trouble." The payment was made.

The French Government having placed restrictions on importations made in ships not under the French flag, Girard, towards the close of 1802, made preparations to trade in French vessels. He began by writing to his old Captain, Pierre Demay. "The general peace now offers a new field for speculation. The advantages offered under your flag in the ports of France may induce me to have one of my ships sail under it, particularly if you are willing to sail from here to France. I believe such voyages could not fail to be profitable if they are managed with econemy."

His next step was to apply to Messrs. Millot \& Toussaint of Havre. "The principal object of this letter is to ask you to freight on my account, in your port or any other, a French ship commanded by a good captain, well 


\section{TRADING WITH FRANCE AND RUSSIA}

rigged, staunch, of a burden of two hundred casks of tobacco, but not exceeding this latter quantity, for the following voyage and under the following conditions.

"I. The Captain shall proceed as quickly as possible to City Point, or Broadway on the James River, in the State of Virginia, and when the said ship shall have arrived in one of these two ports, the captain shall go to Petersburg to inform his consignee Mr. Wm. Douglas of its arrival and give him at the same time the letter of which he shall be the bearer.

"2. You will give to the said captain a letter for Mr. Douglas to inform him that the ship has come to his address to be loaded with tobacco agreeable to my instructions." $* * *$

The freight must not exceed eighty francs in cash and the captain must engage to stop at Falmouth, England, on his return and from there sail to such a port in Europe as might be indicated. The owner of the cargo must deliver it, at his own expense, "under the tackle or at the side of the ship." The freight must "be paid in Europe immediately after the cargo shall have been delivered to the consignee."

"Although the prospects for the sale of tobacco in France are not very good, ** my habit of buying tobacco every year, obliges me to use French ships in order to continue a trade that I formerly carried on under the American flag, but which is no longer practicable unless I am willing to expose myself to the loss of a part of my capital on every voyage."

"We have," was the reply, "just signed the charter party for a vessel of 320 tons at the price of 80 francs per hogshead of tobacco, and $10 \%$, with the provision that she put in at Falmouth in consideration of 1600 francs. She is to return to some French port between Marseilles 


\section{THE LIFE AND TIMES OF STEPHEN GIRARD}

and Le Havre, including the latter: to pass by Le Havre and go to Ostend and Dunkirk 1400 francs additional; and to Antwerp 2800 francs increase. This for your guidance and to enable you to give instructions as to the final destination when she leaves City Point. **

“The vessel's name is L'Éole, Captain Hamel, and her signal is a Norman flag at the Mizzenmast and a white flag at the Mainmast.

"The vessel will leave Honfleur where she now is, between this and the 2oth of April at the latest. We are delighted that we have succeeded in satisfying you in this matter particularly as you have gained at least 16 francs per hogshead."

His third step was to write George Barclay \& Co. of London: "The disadvantage which I have lately experienced in introducing Tobacco to France in American Bottoms induces me to try to have some french Vessel chartered at Havre de Grace, Rouen, St. Valery or St. Malo for the purpose of going to James River in Virginia and there to load with tobacco suitable for the French Market and from there to proceed to Havre de Grace or to any other port which will offer the greatest advantage.

"Should you wish to be concerned in that speculation you may take one half Interest therein, in that case you will have the whole management of that business in Europe on the following conditions" which were then stated in the fullest detail.

Barclay \& Co. declined. "If we had been in the Habit of entering into Operations of that Nature we should most Cheerfully have acceded to your Proposals, but we have in general Confined Ourselves to the Commission Line and to the Management of the Concerns of our Friends, for which Reason we beg leave to decline your very kind offer 
assuring you at the same Time that we shall always retain a due Sense thereof. In the present Instance indeed we knew not how far we might have been Disposed to have taken a Concern with you in the Operation alluded to from the high opinion we entertain of your Prudence \& Circumspection, and from one Conceiving the Plan likely to produce Considerable Advantages, but within a few days a most material change has taken place in political affairs from Differences existing between our Government \& France which have caused great Alarm \& we are now making most Vigorous Preparations for a renewal of Hostilities."

A correspondent at Antwerp "heard, by letter from Nantes, that a frigate with French commissioners on board charged to take possession of the island of Goree has returned to France: they were not received by the English Governor who had orders to that effect eight days previously. It is also reported that an English vessel boarded a vessel under the French flag in the open sea and seized by force three sailors on board of her; these sailors were all of English nationality. It is said that Bonaparte has sent his aide-de-camp Duroc to the King of Prussia to ask permission for the French troops to pass through his dominions to take possession of Hanover and close the Elbe \& Weser to the English flag and that at the present moment a force of 10,000 men is marching on Holland. These premonitory signs of war and our last letters from Paris have so to say deprived us of the hope of keeping the present peace which it appears we are to lose at the very moment we hoped to gather its first fruits and of which the whole world is in such urgent need. $* * *$

"If we have war the price of colonial commodities will go up very much, \& if you have an opportunity to make good purchases you will do very well to take advantage of the chance and send the goods here." 


\section{THE LIFE AND TIMES OF STEPHEN GIRARD}

A firm at Leghorn had received " a copy of the British King's Message to the House of Commons which has spread the alarm throughout Europe of a renewal of war between the two great contending powers. It is superfluous to hazard an opinion on the results of the negotiations which are now on the carpet. $* * *$ It is certain, however, that great military preparations are making on both sides and such is the consternation of the English Merchants established at this place that they are selling or shipping off their property so as to be prepared for the worst."

Millot \& Toussaint of Le Havre said: "The news is most conflicting and one cannot know what to believe. Our condition is like that of a man with fever; one day it is peace and the next it is war, and always the same thing. This cruel state of uncertainty has brought everything to a standstill, nobody ventures to undertake anything. Nevertheless several French vessels which had their cargoes on board left to-day for our Islands: others are getting ready to leave in a few days and still others do not venture forth. Among the latter are the owners of the ship $\left(L^{\prime} E^{\prime}\right.$ ole $)$ we chartered for you. So far they have not ventured to send her out, but have now made up their minds to do so, and with the first favorable wind she will do so without fail. Under present conditions we have not ventured to insist on her departure. On the contrary we ask the owners to delay a little longer, and even tried to get the charter rescinded; but neither of them would consent to that so she will take her chances. $* * *$ We were well satisfied to get this charter, but now we wish we had not done so. We are anxious about the result and regret that the owners would not consent to annul the charter-party. We think circumstances render such a step necessary: but they refused and if we 
had sued them in Court to force them to do so, we should not have succeeded because no active hostility has been committed, and the French Government is chartering merchant vessels to carry troops to St. Domingo."

May roth the Captain came "to get his papers and instructions and we could not refuse him because if we had he would have sailed just the same. We have done all in our power to rescind the charter party but in vain. The owners answer that they have spent 15,000 francs in fitting out and overhauling the vessel and they will only rescind if you pay them that amount. You will understand that we could not accept such a proposition and feel obliged to let the voyage be made."

Contrary winds prevented L'Éole from sailing and on May 16th an embargo was laid on all vessels under the French flag. "On the 2oth we learned through a government dispatch that war had been declared on the 17 th and that the English had on that day seized certain French ships and taken them to their ports. Owing to this unfortunate circumstance the charter we made for your account becomes null and the charter party has deen rescinded by common consent without any indemnity whatever."

Summer was well advanced when Girard received the last of the three letters: but long ere that he was aware of the existence of war. By the middle of April vessels from England brought news of what was coming, news so alarming as to force him to change the instructions to his captains then at sea. To Mr. Ralph Peters, who had gone out as supercargo on the Rousseau, to Canton he wrote, that he was "informed by a vessel arrived in New York after a passage of $3 \mathrm{I}$ days from England that there was a general preparation of war against France. Although this may be the case I do not believe that these two $\mathrm{Na}$ tions are ripe for a Rupture; yet it is best to be prudent, 
therefore should you receive while in Canton the Confirmation of War, I request that you will purchase articles suitable for this market and conformable in quality, etc. to the Instructions which I have given you and to ship them on my account and to my address on board the ship Rousseau for this port."

"Should you at the time of receiving the confirmation of a war, have purchased part or the whole of the ship Rousseau's cargo in articles intended for the European market you must barter them for others fit for this place provided it can be effected without Loss or Sacrifice otherwise you will ship them on board that ship for this port as before mentioned."

Captain Ezra Bowen of the Voltaire had sailed, in April, I803, for Calcutta with Mr. Leopold Nottnagel as supercargo and sixty-seven kegs containing 200,000 Spanish Milled Dollars. Her first stop was to be Madras, where $\$ 50,000$ was to be expended in the purchase of products suitable for the home market. She was then to go on to Calcutta, where the remainder of the specie was to be expended. Hoping to reach the Voltaire at Calcutta Girard now wrote to the Captain: "It is reported that England has declared war against France. Although we have no official account of that unfortunate circumstance, I am fearful that the news is too true. I have no doubt that before this letter reaches you, you will have been informed of that event. In all cases I recommend you to be very prudent in the manner of sailing your ship having attention to keep off cruizing grounds and to avoid as much as possible meeting with or speaking to any vessel. This may be effected by keeping a man constantly at your mast head."

In order to equip the Voltaire with funds for her voyage to Calcutta Girard had drawn on Barclay \& Co. for $£ 45,000$ sterling and sold the drafts to Gallatin, Secre- 
tary of the Treasury. They consisted of two sets of four

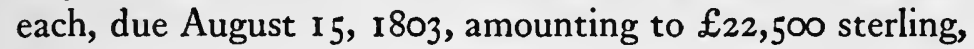
and two sets of four each due November 15th, also amounting to $£_{22,500}$ sterling. But in August, just as the first set fell due, Barclay \& Co. wrote:

"It is with the deepest regret we have to acquaint you that owing to the present distressing situation of Commerce we have been under the dreadful necessity of stopping payment.

"Painful as this communication is, we feel it still more sensibly in seeing you so large a creditor, as your two drafts due this day together $£_{22,500}$ cannot be paid.

"It gives us some consolation to assure you that if our debts are realized in a manner at all proportional to our hopes we shall have ample means to repay every claim against us and to realize a handsome surplus."

As soon as their letter was received Girard enclosed a copy to Albert Gallatin, Secretary of the Treasury, and said: "By the contents of Messrs. Barclay \& Co.'s letter, it is evident that my Bills on them for $£_{45000}$ sterling which I have negotiated you payable on the I $5^{\text {th }}$ August last and I 5 th November next will be protested for non-payment. In addition to this Sum, those Gentlemen are indebted to me of about $£_{12, \infty}$ sterling, consequently I am their creditor of nearly $£ 60, \infty 0$ Sterling. That unfortunate circumstance puts me under the necessity to request as a particular favor, that you will grant me a reasonable time to reimburse you the amount of the Bills before mentioned.

"In lamenting the loss which I will probably meet, I have the satisfaction to make you the following declaration and proposal which I trust will merit the continuance of your confidence.

"I have three ships with their cargoes at sea, on their voyages to India. I expect them back next spring. Besides this I have a ship building in Philadelphia county, 


\section{THE LIFE AND TIMES OF STEPHEN GIRARD}

and another ship in this port, which arrived some time ago from Russia, with a cargo on my account, which is principally unsold. I own also two fifths of the ship Fanny and Cargo. This latter is expected from Sumatra in the course of two months. To this I may add the goods which I have on hand, my real estate and out-standing Debts and about $\$ 40,000$ of U.S. 8 pc, and Insur Compy of Pennsylv Stock. The cargoes of the ships which I have at sea, consist of Four Hundred and Forty Five Thousand Dollars in Specie, and Nineteen Thousand Four Hundred Eighteen Dollars 7r Cents in Goods amounting together to $\$ 464,4187$ 7 / 100 without comprehending the value of my ships which are all sheathed with copper, and could not be purchased for $\$ 100,000$. My debts are trifling, I have at present but one note of Two Thousand Dollars out, and the Deposit I have in our Banks exceeds all I owe in the world."

Having made this statement of assets he proposed to insure his goods and specie at sea for $\$ 300,000$; make over the property at sea and insurance policies, United States $8 \%$ and Insurance Company Stock to the sum of $\$ 300,000$ as Collateral security for the bills: give a power of attorney to any banker for the United States in Europe to collect the dividends that might be paid by Barclay \& Co.; and that on the arrival of any of his ships from India, should the bills still be unpaid, the Voltaire, or the Rousseau, or both, should go at once to Europe, and the proceeds of their cargoes be deposited to the credit of the United States. He then requested that he be not charged with the damages and re-exchange "which is usual among merchants whenever Bills come back protested."

On its way to Washington this letter was passed by one from Gallatin.

"It is with real concern I inform you that by yesterdays mail the Treasurer of the United States received a letter 
from Sir Francis Baring \& Co of London, enclosing protests for non-payment of the two bills of $£_{11,250}$ Sterling each drawn by you on Messrs. George Barclay \& Co. in favor of Montgomery \& Newbold's and R. Bethell \& Son.

"The protests will be forwarded by this day's post to Mr. Simpson Cashier of the Bank of the United States, who is authorized by me to receive from you, the amount of the bills with costs, damages and interest thereon, according to the custom of merchants in Philadelphia."

The day this was received there came a letter from Alexander Baring, then in Philadelphia. "I have received from London a letter on the subject of some business you are interested in and had intended doing myself the honor of calling on you to converse with you about it, but have been deterred by apprehensions that the part of the city you inhabit might be dangerous to persons who, like myself, are fresh from the country. I, in consequence, take the liberty of requesting you will name any place where I can meet you, or if not inconvenient to you, I shall be glad to see you at Mrs. Jones's on Market street next door to the Philada Insurance Compy office where I lodge, at any hour you may please to appoint. The unfortunate state of the city will, I trust, be considered by you a sufficient apology for the liberty $I$ take in requesting you to call on me."

The invitation was accepted and at nine o'clock the next morning Girard called on Mr. Baring. The meeting was a memorable one in the commercial career of Girard, for then and there was begun with the London house of Sir Francis Baring \& Co., a business connection which continued without interruption to the death of Girard twenty-eight years later.

Aware of the failure of Barclay \& Co., and the standing of Girard as a merchant carrying on extensive opera- 
tions in Europe, Mr. Baring saw an opportunity to secure an important correspondent and tendered him the services of his house.

The agreement then made is set forth in a letter written by Girard, the same day, October I4th, I803, to Sir Francis Baring \& Co., London.

"Mr. Alexander Baring, who is at present in this city, has been so obliging as to offer me his kind services in the business alluded to. He has also given me to understand, that if the letter which he intends to write you reaches your hands, before you have forwarded to the Secretary of the Treasury of the United States my 2 last Bills of Exchange on Messrs. Geo. Barclay \& Co. amounting to $£ 22,500$ Sterling which I presume will be protested for non-payment, that they will be taken up by you on my account. Should this be the case you will render me an essential service, and may rely on my strictest punctuality in making you the necessary payments in due time."

"Since writing the foregoing Mr. Alexander Baring and me have wrote to the Treasurer of the United States for the purpose of obtaining his consent that my Bills of $£_{45}, 000$ sterling on Geo. Barclay \& Co. should be placed by you to the Credit of the United States as if they had actually been paid. Should that arrangement take place I will give ample security to $\mathrm{Mr}$. Baring and will send to London as soon as possible one of my ships which I have in this port with One Hundred Thousand Spanish Milled Dollars to your address and for the remainder you may rely on my punctuality.",

To Gallatin he wrote: "Concerning the unfortunate circumstance which has been the cause of the protest for non-payment of my bills on George Barclay \& Co. I thought that the proposals of the Cashier of the U. S. Bank was rather hard on my side, indeed they were of 


\section{TRADING WITH FRANCE AND RUSSIA}

such a nature as to put it out of my power to comply with his request. This, together with my sincere wishes to prevent any loss or damages which the United States may sustain, by detention or otherwise, has induced me to converse with $\mathrm{Mr}$. Alexander Baring on that subject. That Gentleman has shown the greatest disposition to be serviceable to me, and has promised that the house of Francis Baring \& Co. will place to my debit the four bills which I have negotiated to you on Messrs. George Barclay \& Co. of London amounting to $£_{45}, 000$ Sterling, and will also remit that amount to Amsterdam agreeable to your instructions, but previous to making such engagements with me, he wishes to obtain your consent, consequently he writes you by this opportunity and under this cover. Persuaded as I am that your principal object is to do justice to the United States and to the Citizens thereof, I have no doubt that your answer to $\mathrm{Mr}$. Baring and to me will enable us to make the necessary arrangements as to answer the first object of the Secretary of the United States, and to modify the severe loss which I will sustain by this most unpardonable and unfortunate circumstance."

Unable to find an Express who would engage to go to Washington and return within five days, the letters of Girard and Mr. Baring were sent "by a young gentleman of Confidence."

Gallatin replied: "I cannot consistently with my official duty consent to any arrangement having for its object the relinquishment of the Damages and $\mathrm{Re}$-exchange to which the United States are justly entitled by reason of the nonpayment of your bills on George Barclay \& Company.

"Considering the large remittances which the United States are under the necessity of making annually to Europe departure from the established usage of Merchants,

Vol. I-28 433 


\section{THE LIFE AND TIMES OF STEPHEN GIRARD}

in regard to protested bills would operate not only to render those remittances less secure, but to offer just cause of complaint from those persons from whom damages have been exacted."

The Bank of the United States accordingly, on October 28th, made a formal demand on Girard "for an immediate settlement of his two protested Bills amounting to $£ 22,500$ with damages, etc."

In a letter to Mr. Baring, Girard had requested as a particular favor, "that you will propose to the Secretary of the Treasury that I will reimburse him the first two bills of exchange amounting to $£ 22,500$ sterling, with the usual damages, in my bills on Sir Francis Baring \& Co. of London provided said Secretary will agree to relinquish the damages on my bills due the 18 th of next month, if they should be protested for non-payment, and will also consent that the London house will place to the credit of the United States the last mentioned bills amounting to $£ 22,500$ sterling as if they had been regularly paid."

Mr. Baring, Gallatin replied, "has no objections and leaves to your option to pay for the $£ 22,500$ already returned either by fresh bills in the manner you propose or in dollars here. $* * * *$

"You will consider all the circumstances of your situation and determine in what manner you prefer providing for the first issue of bills returned. Should it be by fresh drafts on London I have informed Mr. Gallatin that I would readily endorse the bills which will make both you and him easy about their being duly honored in London, and he is ready to dispense with the addition of the former endorsers which the idea that he could not vary the security of the United States would make him otherwise consider as necessary. If you pay by new bills you will please to forward to me your draft on Sir F. B. \& Co. 
for $£ 27,000$ which, on your assuring me that you will make the shipment you propose without delay, I shall now endorse to the Secretary and withdraw the former drafts with protest."

The choice was soon made and November 12 Girard wrote Sir Francis Baring \& Co.: "Since my last of the 7 th instant I have settled with the Secretary of the Treasury of the U. States for my Bills on Geo. Barclay \& Co. of London amounting to $£ 22,500$ sterling protested for nonpayment. In settling those returned bills the Secretary has insisted on the damages, charges and re-exchange as you will see by the enclosed statement and receipt of $\$ 124,215$ which I have paid to Geo. Simpson, Agent of the U. States. In deducting from that sum One Hundred Thousand Dollars which I have received from the Secretary at the delivery of said bills which I have negotiated to him at the rate of $1662 / 3 \mathrm{pr}$. ct. leaves twenty four thousand two hundred fifteen dollars and $21 / 100$ which $I$ have paid over and above the sum which I have received."

The fate of the second set of bills which fell due in November was made known by a letter from Sir Francis Baring \& Co., written in December, regretting "extremely that only from our want of knowledge of your respectable house, we should have been prevented from rendering you service to that extent which we should otherwise have readily done, but your 2 first drafts for $£_{I I, 250}$ each $\mathrm{Pble}$ I5/18 August falling due the day after Messrs. G. Barclay \& Co. stopt payment. We of course were obliged to act regularly and return them immediately under protest for non-payment to the Secretary of the Treasury of the United States for whose account they had been placed in our hands, but your 2 latter drafts for $£_{11}$, 250 each pble I 5/18 November have been retained by us purposely in expectation that the Assignees of 
Messrs. G. Barclay \& Co. would be prevailed upon to pay us a dividend thereon for as much as they had assets in hand and thereby prevent the possibility of the estate being liable to the re-exchange." They were not disappointed and November 24th the Assignee paid a dividend of $15 / 6$ on the Pound or $£_{17,437 \text {.10. The }}$ remainder, $£ 5062.10$, was paid by Baring \& Co.

Barclay \& Co. owed him other sums. "There is in my statement No. 2," he wrote, "two items respecting my brig Polly and cargo, Capt. John Congdon, and the brig Sally, Capt. John Cochran, the latter is in joint account between that Captain and me. Both vessels and cargoes were captured by the British and returned under the Treaty of amity and commerce and navigation between the United States of America and Great Britain. By Messrs. George Barclay \& Co., letter dated 2ist July last they had received from the Government on account of the brig Polly and cargo £7223.I4.90. and £2290.II.Io. on account of the brig Sally payable in three installments $\mathrm{I} / 3$ on the 15 th of last July, I/ 3 on the 15 th of July 1804 , and $\mathrm{I} / 3$ on the 15 th July 1805 , and that they now receive the first instalment on each vessel and cargo. Consequently the awards or Certificates for two thirds of the whole must be still unpaid and remain in their hands or in the hands of the assignees of their Estate. Therefore it will be necessary that you should immediately take those vouchers into your possession."

Six months later the assignees made a further pay-

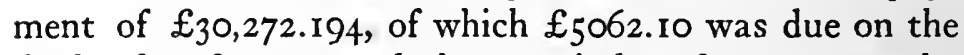

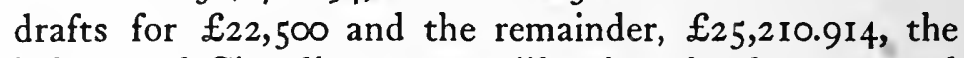
balance of Girard's account, "leaving the damages and re-exchange on the returned Bills for future adjustment."

At the time of their failure Barclay \& Co. had in their hands $£_{59,000}$ sterling, belonging to Girard. 


\section{CHAPTER XI}

\section{THE CLAIMS ON FRANCE}

PeAce had scarcely been made with France in 1800 when Napoleon, by the secret treary of San Ildefonso, acquired from Spain the vast domain known as Louisiana.

The purchase of Louisiana concerned Girard because twenty million livres were to be used by the United States to pay her merchants for spoliations committed on them by France. The war concerned him because of the effect it would have on the fine trade he was carrying on with the ports of Western Europe.

The convention concerning spoliations provided that

"The debts due by France to citizens of the United States, contracted before the 8th Vendémiaire, ninth year of the French Republic (30th September 1800) shall be paid according to the following regulations, with interest at six per cent to commence from the periods when the accounts and vouchers were presented to the French Government." Article II explained that "The debts provided for by the preceding article are those whose result is comprised in the conjectural note annexed to the present convention, and which, with the interest, cannot exceed the sum of twenty million francs."

In the conjectural note were one hundred and twentythree claims. Number 104 was that of "Ellison capitaine du Good Friends 182,1 57 livres, 8 sous," Number I 10 that of "Girard, Stephen Solde d'une Lettre de change 16,537 livres, 10 sous"; and provision was also made "pour ro5 bâtiments à Bordeaux par suite de l'embargo de 1793." The 16,537 livres ro sous was the amount due him for the passengers carried to France at the ex- 
pense of the French Republic, by the Liberty when she went to Bordeaux as a cartel in 1798 .

Encouraged by this provision Girard, in August, wrote to the Secretary of State: "Being informed that the debts due by the French Government to individual citizens of the United States are to be liquidated in France, and having long ago deposited in your office the documents, etc, relative to my french claims, accompanied with my memorial respecting the same. I take the liberty to request that you will be so obliging as to let me know where and in what manner I am to apply for the adjustment and settlement of said claims." **

In the absence of the Secretary the chief clerk replied: "The treaty with France provides for the payment of debts due citizens of the United States who have been, and yet are, creditors of France for supplies, embargoes and also for the captures comprehended in the Convention of the 3oth Sept. 1800 . Interest at $6 \%$ is to be paid upon the debt from the time when the accounts and vouchers were presented to the French Government. These claims are to be ascertained by three persons who are to be immediately and provisionally appointed by the Minister Plenipotentiary of the United States at Paris. An American Agent is also to be appointed to assist in the business. The claims which may be admitted are payable in drafts of the Minister of the U. States on our Treasury Sixty days after the exchange of the ratification and after the delivery of possession of Louisiana. The sums to be thus paid by the United States are not to exceed 20 mill of Francs in the whole.

"You will therefore do well to transmit the evidence of your claims to Paris, without delay, if you have not already done it, either to the Public Agent Fulwar Skipwith, Esq., or to your private agent as you may prefer." 
Girard selected Mr. Robert Peter Branu and sent him to Paris to take sole charge of the claims against the French Republic. The instructions to Mr. Branu were long and elaborate. "With this I hand you my power of attorney with duplicates of documents respecting my claims, against the French government amounting agreeable to statement hereto annexed and divided in two classes as follows:

Ist $£ 77,856, \mathbf{1} 54$ Tournois.

2 d $\$ 83,623.46$ cents Dollars.

"I sent last year Mr. Joseph Curwen for the purpose of closing that business, but it was in vain. After having remained in France for about ten months he was forced to substitute his power in favour of Mr. Luke Callaghan.

"A little time after the arrival in this city of Mr. Joseph Curwen, I judged prudent to send my power of atty to Messrs. Geo. Barclay \& Co. of London. * * * However, war between England and France having taken place and the communication between those two countries being stopped I was dissappointed. This circumstance together with the unpleasant situation I was in, for want of advice from Mr. Luke Callaghan who has not yet wrote me, has induced me to write several letters to Messrs. Strobel \& Martini of Bordeaux to whom I have also sent my power of Atty. Although I have no reason to think these gentlemen will neglect my interest yet it is reasonable to suppose that a person of confidence and competent to do business, who will go to Paris for the sole purpose of recovering my claims, etc. will manage this affair intrusted to his care much better than one who has the charge of a house which carries on an extensive trade." Therefore Mr. Branu was selected and sent with letters to Mr. Livingston, Fulwar Skipwith, Strobel 
\& Martini and Mr. Callaghan. Full information was also given him in regard to the brig Kitty condemned at Guadeloupe; the embargo of the Good Friends at Bordeaux; the detention of the goods on the ship Kensington at Morlaix; the losses sustained by the Nancy at Guadeloupe; the 150 barrels of flour delivered to the Government at Cap Français, and the "delegation of Sonthonax."

On arriving at Paris Mr. Branu called first on Livingston, "who told me very kindly that he would do all in his power for the success of the claims; he did not ask me any questions and retired. Next I went to the office of the Secretary, where I found the Secretary, M. Mouchet, whom I knew very well in Philadelphia. ${ }^{* * *}$

"Mr. Skipwith received me very courteously and promised me his assistance in everything that might conserve your interests.

"When I asked him to introduce me to the American Commission he made an appointment with me for the next day.

"I also went to the office of the French Liquidation and there found M. Chevalier, an old partner of Loir's. $\mathrm{He}$ is also an old acquaintance of mine, and as he is employed in this office, I hope will be able to do me a service if the occasion presents itself and particularly post me as to the routine of the office.

"I presented your letter to M. Perregaux who promised me to do all in his power to contribute to the success of the business. ${ }^{* * *} \mathrm{Mr}$. Callaghan received me with great cordiality. I had an explanation with him so that I count on his continued cooperation, as I did not tell him that I would take the business out of his hands nor that I would leave it with him, and he promised to cooperate to the full extent of his ability to bring about a settlement of all these matters. We talked a good deal 440 


\section{THE CLAIMS ON FRANCE}

about the Kitty which he considers a most difficult matter. He has presented a petition relating to her to the Chief Justice (Régnier) who answered him in writing. $* * *$ He told me that General Leclerc's draft for 5052 francs remained in the possession of Melville who has fled, and that he had received from M. Feuillet, the said Melville's clerk, $3 \%$ of the said principal sum, namely I5I francs II.2 from which there was deducted a commission of $2 \% . * *$ As for the rest of the money he considers it lost. *** I have not been here long enough to learn the news. I was sorry to hear that there was some misunderstanding among the members of the American Commission which appears to be opposed to the minister; and I was told yesterday that a petition was being sent around for signature to obtain a change of commissioners. Their names are Mercer (son of the general) Mc Clure and Cox Barnet. The first is said to be an insignificant young man; the second very dangerous and an enemy of Mr. Livingston, and the third is believed to be a well meaning individual. They also say that the plan of these gentlemen is to create difficulties and tire out the interested parties in order to oblige them to sell their claims, in short to speculate at the expense of their fellow countrymen. If the petition is presented to me I shall not sign it.

"There is another difficulty that I have been unable so far to fathom. It relates to the term used in the agreement between the two governments. The English word 'supply' has been translated by the French word 'fournitures' and the French Government interprets it as applying only to food supplies, while the Americans understand and contend that the word 'supply' applies to every kind of provisions, food-stuffs, money, chartering of vessels, etc. I am very much afraid that the difficulties caused by this misinterpretation may pro- 
tract the time fixed for the final adjustment of their claims.

"There is also some misunderstanding in regard to the nature of the claim. When the agreement was made Mr. Skipwith in his capacity of Commercial Agent drew up a statement of the claims of citizens of the United States, on the other hand M. Guillaume, one of M. Marbois's heads of departments, drew up another statement based chiefly on the principle that supply means only food supplies thus giving rise to an approximate statement which Mr. Skipwith calls a conjectural note from which various articles are omitted. As it stands now you are mentioned in this note only for the two items mentioned in the article relating to Swan. (These were, 150 barrels of flour delivered by Swan at Cape Français with nine years' interest, in all, 22,942 livres, 8 sous; and the draft of Consul General L'Etombe with four years' interest, in all, 942I livres 17 sous.)

"I am told also that the 20 millions reserved from the Louisiana fund will not be sufficient to cover these claims which amount to more than 30 millions. ***

"February 24th I have just returned from M. Callaghan's who gave me a copy of the letter written by him to the Chief Justice about the $2 \mathrm{~d}$ of January with the Answer from the said Magistrate under date of the roth. You will note that it is the province of the prize court to confirm or annul the judgment, and, so far as I can judge from the meaning of his words, his interpretation appears to be that neither the government nor the administrators are responsible for the consequences, but that the responsibility lies with Linard \& Co. or their bondsmen, if the Court annuls the decision of the administrators."

The petition of Mr. Callaghan set forth that in 442 
August, 1793, the Kitty was sent to Jéremie on the Island of San Domingo with a cargo of provisions to supply the needs of the colony; that from Jéremie she sailed with coffee and cocoa for Philadelphia, and after "being battered by the gales for 35 days, his vessel in disorder, part of his crew sick, and without his mainmast, which had been cut down, captain Waters, unable to reach the continent, made for Guadeloupe and there sought refuge and hospitality. In this sad plight 3 leagues N. W. of Basseterre, he was met on the gth of January 1794 by the French privateer L'Intrépide commanded by André, and unmindful of the law of nations and his duty toward those in distress, he was seized and taken into port.

"The question was tried before the District Court of Basseterre which, finding the papers in perfect order and the property unquestionably American, ordered both vessel and cargo restored according to the decision made under date of January 18, 1794. But the owners of the Privateer, Linard \& Co., seeing that they were about to lose their prize used all their influence with the Governor and Civil Administrator who, in defiance of the judgment rendered, confiscated the Kitty and all her belongings for the benefit of L'Intrépide.

"The Commissioner and the members of the District Court as well as Captain Waters protested against this arbitrary act, which was essentially null and void on account of the incompetence of those who permitted it. But what were they to do against the constituted authorities? Thus Stephen Girard was deprived of his property and was unable to protest until the treaties were fortunately concluded between the French government and that of the United States."

Therefore the petitioner prayed that the decree of January 18, 1794, "be fully and entirely executed." 
To this the Grande Juge replied: "I observe Citizen, in the document you have sent that the judgment of the District Court of Basseterre dated January 18, 1794, and relating to the restoration of the brig Kitty was rendered merely in the form of an opinion.

"It is our opinion (so it reads) that the brig Kitty and all belongings to her be released. $* * * *$

"The judgment then goes on to say as according to the laws and forms observed up to the present time, the Court has pronounced judgment only in the form of an opinion, and as all further measures are beyond its jurisdiction, the Court leaves all such to the proper authorities.-The Court thus having dismissed the question, the Captors applied to the administrators of the island, the latter, that is to say, the Governor and the Civil Director of Marine, ordered the confiscation of the brig and all belonging to her for the benefit of the privateer, provided that the owners furnish good and valid security.

"Thus the judgment and decision of the administrators do not seem to have been more than provisional measures, which it is the duty of the prize Court to confirm or annul.

"You must therefore address your claims to said Court."

Concerning the reply of the Judge, Mr. Branu remarked: "In my letter of the 23d February I sent you a copy of the letter written by Mr. Callaghan to the Chief Justice in regard to the Kitty and the reply of the said magistrate. At that time I thought that the petition presented to the prize court which the said Mr. Callaghan spoke of as not having been granted had not produced any definite result, and that it behoved me to make an effort to obtain a decision in the matter. A ship captain to whom Messrs. Millot \& Toussaint recom- 


\section{THE CLAIMS ON FRANCE}

mended me, and who turns out to be an old acquaintance of mine, introduced me to one of the clerks in the offices of the Navy in the department of prizes. I gave him a statement which I had prepared about this matter after carefully studying it. After reading it he said that my exposition seemed to be just; but that he had never heard of this claim and would inquire about it at the Prize Court and find out what had been done. When I came back to see him, he said that the Prize Court had finally decided that the appeal I hoped to make from the decision of the Administration of Gaudeloupe was useless; that the question could not be reopened; and that he was very sorry as he would have been very glad to help me. I went at once to Mr. Callaghan and asked him if the Prize Court had sent him an extract of its decision respecting the Kitty. He said it had, and that he had sent you a copy, and at the same time gave me the original of which you have herewith another copy. If, instead of giving me a letter from the Chief Justice, he had given me the extract, it would have saved me a good deal of running about. **

"I was struck by the fact that the Court bases its decision on the length of time, ro years, that elapsed without any appeal, and I hoped there might be some mistake, because I felt certain that the interested parties could not have allowed such a long time to elapse without appeal. With renewed energy therefore, I ransacked all your papers and found among them copies of your letters to Mr. Skipwith dated April 12, 1795, and May 21, 1796, and a copy of one addressed to Mr. Monroe dated June 8, 1796. From these I judged it possible Mr. Skipwith might have taken some action.

"I flew to him to ask for information and showed him the decision of the Prize Court. He said he had done 
nothing either in the matter of your claims, or in any others of the same kind sent to him from the United States, that he had intended to make a general application according to the plan and advice of Mr. Pickering; but that Messrs. Pinckney, Marshall \& Gerry, then commissioners from the United States to the French Government had objected, on the pretext, that it was impolitic under the then existing circumstances and that as a result a formal relinquishment was made through the treaty of 1800 as the said treaty recognized only those prizes for which appeals were brought before its conclusion.

"In spite of the unpromising outlook I have not given up hoping it may be possible to appeal from this decision. $* * *$ I do not believe there is any law fixing a limit of Io years in the litigation of a suit in which the parties are not on the spot, and you will notice that no such law is cited. If it is a recent law it cannot, in equity, be given a retro-active affect. According to the old jurisprudence one has 30 years in which to appeal from a judgment by default and as the judgment against the Kitty seems to me to be of that sort, as the Captain was not summoned and did not defend himself, I believe there is a possibility of appealing from the decision and have taken steps to consult a well informed attorney. $* * *$

"What I told you about the disagreement existing among the commissioners is but too true. On the other hand the Commission has arrogated to itself the right to expound the clauses of the convention and to interpret its items although its functions are really limited to deciding whether such and such a claim is or is not American. For example, Mr. Millot of Philadelphia was a claimant for 1,200.000 francs. M. de Marbois entered his name in the note; but the Commissioners saw fit to allow but 100,000 francs, rejecting the remainder as being 446 
the proceeds of munitions of war furnished to St. Domingo, which, according to them cannot be allowed to share in the benefits of the treaty but must be settled separately. This action greatly annoyed M. de Marbois, and I have been told gave rise to the petition which was sent to America, for the purpose of having the Commission changed.

"There has been much complaint against Mr. Skipwith because he is practically both judge and litigant, and it is well known that out of 45 claims he caused 35 to be passed which were recommended by him."

Mr. Branu now addressed to the American Commission a letter describing each claim, and requesting to be informed what was the present condition of each. The reply was that the nine bills of exchange amounting to 48,66I livres, I7 sous, 8 deniers due on January I794, were "not yet before the Board, nor yet on the conjectural note"; that the five drafts "due 24 Pluviare an. 4 amounting to 7753 livres, 13 sous, 4 deniers were not yet before the Board, not being on the conjectural note"; a delegation of Sonthonax on M. Genet for San Domingo Currency 20,7I4 livres, 5 sous, "not yet before the Board not being on the conjectural note;" a claim for I 50 barrels of flour "admitted January 12, r804"; a draft of M. L'Etombe "rejected April 4, I804."

The claim of the Good Friends, M. Branu reported, had been "certified under No. 86 and officially sent to the office of M. Defermont who later apportioned her share of the sum of 3 millions 3 or 4 hundred thousand francs which he has appropriated for the embargoes. As soon as I learn how much the award amounts to I shall let you know."

"The Kensington was not so fortunate. The American Commission gave her a certificate of rejection under No. 
47 on the ground that the treaty does not mention indemnity for detention. The Commission gave this decision on the same principle as that for the balance of L'Etombe's draft because it was derived from freight on a vessel, which is not mentioned in the treaty. In rejecting these claims the Commission does not say that they are not to be paid; it merely means that they cannot be paid out of the 20 millions derived from the Louisiana purchase."

The nine bills of exchange drawn by the treasurer of San Domingo in May I793, and not before the Board, were now made the subject of a petition to $M$. Defermont, "Citizen Councillor of State and Director General of the Liquidation of the Public Debt." They had been given, Branu said, for food supplies delivered to the administration of San Domingo; had been sent by Girard to Paris and recorded by Citizen Thomas Melville "at the Liquidation Office, were there liquidated by mistake as a French claim (probably on account of the resemblance of the name Girard to some French name) and converted into an inscription No. 10430 the income of which amounts to 892 francs, which inscription Mr. Melville believed he had a right to withdraw. $* * *$ Some of this transaction, Citizen Luc Callaghan, having received authority to represent Stephen Girard, impressed with the error committed $* * *$ asked to have the liquidation rescinded and the claim restored to its original status as American property. ${ }^{*} *$ offering to deliver Inscription No. I0430 which Citizen Melville had received and never used."

In this state of the affair, the petitioner goes on to say, Mr. Branu "arrived in Paris armed with a power of attorney of Citizen Stephen Girard by virtue of which I take the place of Citizen Callaghan." He then asks that the drafts be liquidated, for, if "the liquidation of these drafts is withheld, it will be a hardship for the French 448 
Government as it will continue to bear the charge of paying the annuity, whereas, if the transaction is annulled, the American government will have to pay it out of the 20 millions which France has given up for that purpose."

Mr. Branu now set himself to find how much had been awarded the Good Friends. Going to the Government office, "The official to whom I applied told me that nothing had yet been fixed and when I examined the papers relating to the claim he remarked that he thought it might amount to $£_{15,000}$ as a Bordeaux Court had fixed the damages $£_{I}$ I,500. I begged him to take note that there was no proportion between such a paltry sum and I 82, 157 livres, 8 sous, which is the amount mentioned in the 'conjectural note.' $\mathrm{He}$ at once glanced at the note and to my great astonishment showed me that the ship had been entered for only $40,44^{2}$ livres 3 . You see he added, 'that you are mistaken; this is the original.'

"The next day I went to the office of the American Commission where I found that I had not been mistaken and that the first amount of 182,157 livres $8 \mathrm{~s}$, was entered on their conjectural note as the claim due to our vessel. I then asked Mr. Cutting (Mr. Cutting was Secretary to the American Commission) how it was possible that there should be such a difference. He assured me that the note on which the Commission was then at work was based merely on the documents sent from the French offices, and that many mistakes had been made. $* * *$

"I told you on the 9th of May that the American Commission had finished its work on the conjectural note and I learned from the said Mr. Cutting that out of $\sum_{19,889 \text {, }}$ $303,6 \mathrm{~s}, 8 \mathrm{~d}$ which is the total amount of the said note, the Commission admitted only 6 or 7 millions rejecting the rest for various reasons. I told you at the same time that the commission was now busy with the claims that Vol. I-29 449 
had not been entered on the 'conjectural note.' I have heard they are almost through with the examination of the year 2, and as the Nancy Captain Post, belongs to the year 3, I shall probably know the result before long."

In June he had "an explanation in regard to the difference in the amount of the Good Friends' claim which actually amounts to $£_{1} 82,157,8 \mathrm{~s}$. M. Hucher told me that when he at first assured me the amount of this claim was not more than $£_{40}, 44^{2}, 3 \mathrm{~s}$ he forgot the account presented by Mr. Curwen amounting to $£ 34,696,64$ which at $£_{5,5} \mathrm{~s}$ makes $£_{1} 82,157,8 \mathrm{~s}$.

"I told you that within two weeks I should have a definite answer as to the 9 bills of exchange. Owing to the magnitude of this item I moved heaven and earth in my attempt, by means of a douceur, to have the matter reconsidered. One of the persons to whom I had a letter of introduction undertook to do something about it but without result; I send herewith a copy of the note I received about the matter.

"'I have seen M. G., my dear friend, about Girard's affair. He proved to me that the proposition to annul the liquidation is absolutely untenable and the matter has ceased to be within the jurisdiction of the LiquidatorGeneral since an inscription has been delivered by the Treasury.' $* * *$ All this is very distressing. As there is nothing more to be done in this unfortunate matter, I wish you to tell me whether you want me to sell the inscription or prefer to draw the annuity. In the former case you could get, according to the American price of such securities, which to-day is 57 , about £Io, 168,8 s for the $£_{17}, 840$ which represent the principal of an inscription producing an annuity of $£ 892 . * * *$

"I have just heard through Dr. Deveze that General Moreau, who has been condemned to two years imprison450 
ment obtained permission to go to America and left three days ago for Lisbon or Barcelona, escorted only by two gendarmes. The Doctor tells me the General has chosen Philadelphia for his retreat and that his wife, whom he has known for a long time, has sent for him to ask for information. He is going to tell her all she ought to know to enable her to take care of her health and allay her fears about yellow fever. He has named you as the only person the general ought to trust for investing his funds, etc, etc, and has especially, warned him against the clique of 'french business agents,' etc, etc, you understand. *** George and eleven of his accomplices were guillotined this morning."

The life of the Consulate had been one long struggle for existence. Never for a moment was it safe from the attacks and machinations of the Jacobins and Republicans. Plot followed plot not only against the political power, but against the life of the First Consul. Such a one occurred at the close of 1803 when a band of Royalist conspirators, led by Cadandal and Pichegru, once a general of the Republic, made their way to Paris bent on the destruction of Napoleon. Before they could act Paris was startled, early in 1804, by the sensational arrest of Cadandal, Pichegru and many others who had played a part in the insurrections in Brittany and Vendée, and of General Moreau, the victor of Hohenlinden, charged with complicity in the plot. Cadandal and his accomplices were condemned to death; Pichegru was strangled in prison; and Moreau, condemned to two years' imprisonment, was suffered to exchange it for exile from France. Nothing was proved against him. That he had neither part nor lot in the conspiracy was shown beyond question. But he was a true Republican, the idol of the army of Germany, and might be used by the Republicans to 


\section{THE LIFE AND TIMES OF STEPHEN GIRARD}

thwart the plans of Napoleon. As a dangerous obstacle, therefore, he was driven from France, came to Philadelphia and presented to Girard his letters from Deveze.

When July came no further progress had been made towards a settlement of the claims. Branu was forced to report:

"The liquidation is progressing at a most discouraging rate. $* * *$ Some say the American Government has an understanding with the Commissioners, and that the object of all these delays is to force the claimants to sell their claims at a vile price. Again, I have heard some, whom I have reason to believe are fairly well informed, say, that one of the Commissioners is an agent for a London house for buying the claims at a low price."

In the affair of the Kitty, acting on legal advice, Mr. Branu drew up a petition so long and detailed that he thought it necessary to print the document, fearing nobody would read it in written form. Copies of this were given to the judges. By August the American commission had acted and rejected the claim for the Nancy "on the strength of article 4 of the treaty which provides that claims preferred on account of embargo, detention, capture, etc, are not admissable unless the appeal is lodged within the time mentioned in the convention of September 30,1800 ; and it is a strange thing that this last convention, owing to some extraordinary negligence does not fix a time limit for the said appeals, which in fact are not mentioned at all. $* * *$

"Sonthonax's draft on Genet was definitely settled on the 7th August." In October Mr. Branu sent the long awaited statement of settlement. For the balance of L'Etombe's draft Girard was awarded £ro,604; for the I 50 barrels of flour £ro,934; for the draft of Sonthonax on Genet $£_{15} 5,090,8 s, 2 d$. "The five drafts amounting to $\mathfrak{f}_{7753}, 13 s, 4 d$ are regarded as a French claim and they will 
accordingly be liquidated in $5 \%$ Consolidated which will yield about 150 to 160 francs income. This is the best that can be done."

"The Kensington was rejected by the French liquidation." The case of the Good Friends was not yet settled and was "going through a fresh batch of difficulties." The embargo damages, which had been estimated at $£_{40}, 442,3 s$, were reduced to $£_{32,651}, 16 s, 5 d$. The items for indemnity for losses on the merchandise "through leakage of the wine, brandy etc has not yet been determined; there is talk of reducing $£_{37,781}, 17 \mathrm{~s}, 5 \mathrm{~d}$ to $£ 8000$." Indemnity for the goods on the Good Friends was finally "fixed by the council of the French Liquidation at $\mathcal{E}_{11 \text {, }}$ $854,9 \mathrm{~s}, 3 \mathrm{~d}$ which sum added to the $£_{32}, 651,15 \mathrm{~s}, 5 \mathrm{~d}$. granted for the embargo on this vessel makes the sum of $£ 44,506$, 5s, 8d. This is all it will be possible to get on this claim." The five drafts amounting to $£_{7753}$, were liquidated for

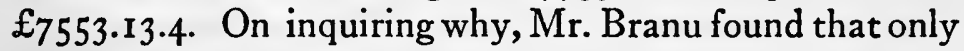
four drafts, had been before the council and that one for $£_{500}$ was missing. Callaghan had forgotten to send it with the others. The inscription in which this claim was paid yielded an annuity of $£_{133}$. In the matter of the Kitty Mr. Branu had also attempted to move "heaven and earth by the use of douceurs" offered to men so high in office that he did not dare mention their names. All he could do was divide the Council of Liquidation which finally, in October, rejected the claim. The decision covers sixteen closely-written pages.

As soon as it was made Mr. Branu appealed to Mr. Armstrong, who had just succeeded Mr. Livingston as American minister to France, asked his aid and said, "that as soon as I should receive a legally certified copy of the judgment rendered by the Council, I should probably find strong reasons to present a petition to the Council 
for the purpose of representing to $M$. Talleyrand the wrongs of which you had been the victim."

"M. Marbois has just gotten himself appointed on a commission to examine the work of the Liquidation Commission, and those who have had their claims rejected will have to make their appeals to this new authority."

The Commission thus appointed "divided its work in four classes."

"I. Claims admitted by the two commissions and liquidated.

"2. Those rejected by the American Commission and admitted by the French.

"3. Those admitted by the American Commission and rejected by the French.

"4. Those rejected by both parties.

"It is not yet known when any drafts will be delivered; it was proposed to give $75 \%$ in order to have $25 \%$ in reserve to supply any deficiency in the 20 millions."

Thus the year ended. The story of two other claims may be briefly told. Messrs. Barclay \& Co. paid their debt to Girard in full, $£ 7223.14 .9$ awarded in the case of the Polly and $£ 2294$ in the case of the ship Sally, and

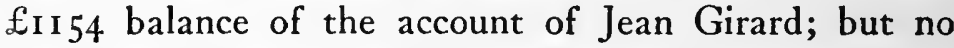
damages for the protest of the drafts and re-exchange.

Damages for the losses sustained by the protest of these drafts caused by the failure of Barclay \& Co., Girard was now seeking from Congress.

About the middle of March the mail brought him from Washington an anonymous letter.

\section{"Dear Sir:}

The writer hereof (who will make himself known at a future day) recommends it to you by all means to make immediate application to Congress for a Remission for the 


\section{THE CLAIMS ON FRANCE}

damages chargeable on your Protested bills, from a firm belief that, under the peculiar hardship. of your case, relief would, without doubt, be granted by them, and that in the meantime, the Secy of the Treasury would not hesitate to defer exacting the payment from you, until your memorial should be definitely decided on.

Take the advice of a friend who, for the present, will sign himself

\section{SYLPH}

Federal City-March I4, I804."

Girard had long in mind an appeal to Congress and this letter from Sylph seems to have decided him to do so at once. March 2oth, accordingly, he wrote Gallatin: "In consequence of my advice from Sir Francis Baring \& Co. of London, under date of the 7 th of last December I intend to make application to Congress for a remission of the damages on my bills returned to you protested for nonpayment. Permit me to solicit your kind interference in that business as far as you will judge it right and reasonable. Please also direct the Cashier of the Bank of the U. States to defer exacting payment from me until my memorial will be definitely decided on."

By the same mail went a letter to Mr. Joseph Clay, a member of Congress, enclosing a note of introduction from Mr. Tench Coxe, and a memorial which Mr. Clay was requested to present to Congress. March 22d the memorial was laid before the House of Representatives; was referred to the Committee on Claims the same day; and was by them referred to the Secretary of the Treasury, who replied to the chairman: "I had the honor to receive your letter of this day (March 23) enclosing Stephen Girard's petition. The facts are truly stated in the petition. I have only to add that the proposition to have the 


\section{THE LIFE AND TIMES OF STEPHEN GIRARD}

bills (after they had been returned protested for nonpayment to the Treasury) passed to the credit of the United States as if they had been paid was made by Mr. Girard as well as by Mr. Alexander Baring in October last and was rejected; Ist, because considering the large amount of bills (more than two millions of dollars) annually purchased on account of government, it appeared absolutely necessary never to give up the damages whenever a legal right to them had accrued, and because the right has in every instance, without regard to persons or circumstances, been inforced.

" $2 \mathrm{~d}$ Because if abandoned in this instance and for that reason, every drawer who was solvent might by making a remittance to the Bankers in Europe, after bills protested for non-payment had been returned to the Treasury, induce them to make a similar offer and evade the payment of damages. $3 \mathrm{~d}$ because the credit offered by Messrs. Baring, as of August last, was not and is not wanted, measures having been immediately taken on hearing of Messrs. Barclay's failure to replace the deficiency by other remittances, 4th because the offer made in March to give credit in England as of August preceeding cannot in reality be effected. The money was not there in August and every damage which may have arisen on account of the disappointment has already been incurred and cannot in any degree except so far as relates to the United States be remedied by that offer."

The Committee therefore reported (March 24) that "before the prayer of the memorialist can with propriety be granted further deliberation would be required than the short residue of the session will allow." Further consideration the Committee advised "be postponed untill the first Monday in November next." As Congress would not be in session on that day this was a parliamentary way of 
recommending rejection and the House (March 24) so ordered.

In May a copy of the letter of Gallatin and the report of the Committee were sent to Girard by "Sylph," who said: "I have seen with much pleasure that you had presented a memorial to Congress for a remission of the damages incurred on your protested bills according to the advice which I gave you under the signature of 'Sylph' and I would have addressed you under the signature of my real name before this time had I sooner been able to procure a copy of the proceedings of the House on your claims. This I have now obtained and will transmit it herewith." His real name was John Brown, "formerly a merchant" who resided "in Philada and kept my Compting house on Walnut Street wharf," and was once "owner of the ship Hamburg Packet," and had "dealings with you" and was afterwards a clerk in the Treasury Department. More advice was given, the substance of which was that such a man as Girard ought not to submit to such a wrong but should again petition Congress. As a fit recompense for any service he might render Mr. Brown stated that Girard might make him supercargo on one of his vessels going to India.

Girard in reply thanked him for his trouble, said he would make a second appeal, begged him to "be so obliging as to continue me your good advice, etc, etc" and said he would remember him if anything for India offered.

Despairing of obtaining relief from Congress, Girard now turned to Barclay \& Co. and in August wrote Sir Francis Baring \& Co.: "In regard to my expectation of receiving here a remission of damages etc on the bills alluded to I have petitioned Congress who have immediately referred my claim to the Secretary of the Treasury; the report of the latter having been unfavorable I 
have given up the idea of making any further application; therefore I have no other alternative than to recover from the acceptors who alone are the sole cause of the heavy damages etc which their unparallelled conduct has occasioned." Sir Francis Baring \& Co. were accordingly requested to apply to Barclay \& $\mathrm{Co}$. for the damages, amounting to $\$ 28,862$.91.

While Girard was worrying over the fate of his bills on Barclay \& Co. ships from abroad brought letters informing him of the death of his brother Jean, his sister Victoire and of the financial distress of his aunt Lafargue. Since the death of his father and his purchase of the house in Rue Ramonet, the house in which he believed he was born, it had been occupied by the aunt and sister. The greater part was rented to a lodger who paid two hundred francs a year rent, and on this and a pittance of fifty francs a month allowed each of them by Girard, the two women managed to subsist. By 1802 rise in prices made necessary an appeal for a more generous allowance.

"Although I have been forbidden to write to you I feel compelled to let you know our pitiable condition both Victoire's and mine. We lack the necessaries of life and we are living miserably on what we can borrow from other people around here without being able to avoid it. I have never relaxed my economy, but the extortionate prices asked for everything make it impossible to satisfy our creditors who furnish us the bare necessities. The baker, the butcher, the wine merchant and the wood merchant charge more than we get from you alone. Victoire needs a very delicate diet on account of her illness; and her washing, although very moderate, is costly nowadays because everything is high in price, even more so for us because we cannot lay in stock. They absolutely refuse to give us more than fifty francs every month and 


\section{THE CLAIMS ON FRANCE}

when we receive those fifty francs we owe more than 60; there are always bills. That is what I call living on borrowed money without being able to lay in any provisions, so that I pay too much for everything such as soap, oil, coffee, moist sugar, etc. I pay more for everything because I take it in small quantities and Victoire's tobacco has to go very far. The cheapest wine is worth 20 sous a pint. Three-fourths of the year Victoire eats her bread dry as I cannot even let her have what she needs. Victoire is very much in need of linen; she is without handkerchiefs and other very necessary articles. She spends all her time alone in the little room in the back of the house because of the noise of the wagons in the street. She stays at the back of the house and all she needs is a little garden to get the air. She fumes against Mombrun (Jean Girard) and Sophie. In short, my dear Citizen, we implore your protection. If you will only do a little to help us I shall pray for the preservation of your health and be most grateful. Since Mombrun has quarreled with us I have written you three letters without getting any answer, and I implore you once more to write to us, sending your letters to la Rue Ramonet No. I. I do not believe they give us the letters you write us. We should not be so badly off if you were well informed of our sad condition."

The allowance was doubled and writing to Strobel \& Martini he said: "I have an aunt and a sister in Bordeaux to whom I give twelve hundred livres tournois per annum paybl quarterly. The name of the former is Anne Lafargue and of the latter Victoire Girard, they live in Rue Ramonet au Chartron, Messrs. Hourquebie Brothers were in the habit to pay them that annuity on my account but, as I have taken my business out of their hands I beg that you will pay on my account to said Anne Lafargue and 
Victoire Girard Three Hundred livres tournois every three months."

The sister, Victoire, died in 1803 and before the year ended his brother Jean died in the Island of St. Vincent. The last years of his life was spent sailing about the world in his own ship, trading now at Lisbon, now at St. Sebastian, now at Hamburg or Bordeaux and filling his letters with complaints of ill luck, unasked advice, offers of service, and reproaches that his brother who had no confidence in his business ability, gave commissions to strangers and none to him. Early in 1803 he was in Bordeaux with his brig Lucie "about to leave for Senegal," on his way to Sierra Leone, "to find out what has become of the cocoa taken by my brig Mentor." On the way thither his brig Lucie, was captured by a British sloop of war and ordered to the Barbados, but went to St. Vincent, where in November he died. When Girard heard of this he wrote Hourquebie: "On the $2 \mathrm{~d}$ of November last my brother wrote me a letter to ask me to obtain from our custom house some documents that he says are necessary before he can proceed. By the same mail I received a letter from Messrs. Solomon I. Stowe \& Co in which they announce to me the cruel news of the sudden death of my brother. This news afflicted me so much the more on account of this unfortunate man leaving behind him four children to the care of a mother who does not deserve the name. She left here about two months ago to go to Charleston on the pretense of regaining health. Her residence seems to be a secret. She intends to return next spring.

"Since the departure of my brother from here I have been supplying the needs of his family. As far as I can see he has no means here. He is even my debtor for about 2600 dollars a sum daily increased by the maintenance of the children, house, rent, etc. 


\section{THE CLAIMS ON FRANCE}

"From this you will understand how important it is to preserve, as far as possible, the remaining fortune of the father of these unfortunate children. I therefore beg you very earnestly to let me know how you stood with my brother, to send me your account current, and keep in your hand the balance that may be due his estate, until further notice from me. As to the brigantine Lucy from what my brother wrote me in regard to the crew, who testified against him, I very much fear this vessel will be condemned to the profit of the captors. If this is the case I hope she is insured in your city by good underwriters against all risks. Kindly tell me how this matter stands, also as to that of his brig Mentor Capt Jacobs."

To the widow, who, just at this time, ignorant of the death of her husband, wrote from Charleston for money, he replied: "Nothing less than the death of my brother, John Girard, induces me to write to you. He departed this life in the Island of St. Vincent, on the 5th of last month after having been brought in there with his brig Lucy by a British Cruiser. While I lament and regret the loss of that unfortunate brother I meet with some consolation in thinking that he is relieved forever from his daily difficulties and dissatisfaction particularly when I represent myself with the death stroke which he should have received by hearing at his return to this city, of your precipitate departure for South Carolina.

"I do not wish you to believe that the intention of this letter is to convey any reproach. I leave that to your conscience and will confine myself to what I conceive to be my duty, therefore as brother to the deceased I will relate you the steps which I have taken.

"Ist. Immediately after hearing of the death of my brother I have wrote to several persons with whom I supposed him in habit of doing business and have request- 


\section{THE LIFE AND TIMES OF STEPHEN GIRARD}

ed them to send me their accounts and to remit me the balance thereof.

" 2 d. have taken letters of administration and have proceeded to the house of the deceased accompanied with Mr. George Hunter and Mr. Hy Roberjot with the intention to examine if the furniture in the house did correspond with the Inventory which you have left with Mrs. Philips. Finding that lady in the house and everything therein appearing to be in its place, we have opened two closets in what is called the tea room where we found in one next to the front window sundry printed Books, the other contained plate, Linen and other articles, of this we have taken an Inventory sent the plate to my house with a small cane, put the remainder of the effects in same closet. We have also opened a bureau containing principally papers which we did not examine and have sealed up every draw as also the doors of the two closets.

"Presuming that there was no necessity to examine any further and wishing tc take no steps which will create any uneasiness I have left the whole furniture together with the children under the care of Mrs. Philips until your return, consequently I entreat you to come back home immediately so some arrangements may take place respecting these fatherless children."

She came and for a while supported herself and children by pledging plate and furniture and borrowing small sums from such neighbors as would lend. When no more could be borrowed Girard was appealed to and sent a hundred dollars to redeem the pieces of plate and furniture, and a hundred and fifty dollars to pay the debts, and offered sixty dollars a month for support of the family provided the pledging and borrowing ceased. The offer was accepted, but the pittance proved too small and one day in July I 805 , the three children, Antoinette aged 
nine, Caroline aged seven and Henriette aged five, scantily and shabbily clad, "almost naked," says Girard, came to his house in search of a home. Great was his indignation and astonishment; but the children were received, put under the care of his housekeeper, and the two eldest promptly sent to a boarding school in Bethlehem. For the son William at school in Soreze he did nothing until the boy died in 1808, when Girard paid the bill for board, clothing and tuition for the last five years. Towards Mrs. Jean Girard he had always shown an intense dislike, had never allowed her to enter his house, and now suffered her to shift for herself till she died in great poverty in 1807 .

It was years before the estate was settled and the return was next to nothing. The Lucy was not insured, the Mentor was wrecked off the coast of Chili, and all that remained of the estate of Jean Girard was $\$ 3475$, recovered, years after, from a debtor in Havana.

On the farm in 1803 , was a young man, a native of Switzerland brought over from Amsterdam and sold to Girard as a Redemptioner. As often happened with men so bound to temporary servitude, after a few years of service he ran away. Neither the loss of his labor, nor the money paid for the man gave Girard any concern. But a contract had been broken, and because of this the Redemptioner must be caught and punished, as the law provided, cost what it might. A description of the man was sent to a Mr. Declary, a correspondent in Pittsburg.

"Allow me to ask you to take the necessary steps to secure the arrest of a Swiss servant whom I lately engaged and whose passage I paid to Capt. George Bullups master of the ship Traveller of Baltimore coming from Amsterdam. Enclosed you will find a description of him. I believe this man has gone to join the Swiss in the vicinity of Kentucky who are said to cultivate vineyards. I beg 
that you will have him advertised for fifteen consecutive days in Pittsburg and Kentucky newspapers and to state in the advertisement that the reward will be paid by you. I will pay you just as soon as you let me know your expenses.

"In case he is found have the kindness to have him jailed, inform me of the fact and await my answer in order to act accordingly."

"I have made all possible inquiries to discover your Swiss servant," Mr. Declary replied. "I have gone to all the inns and ferries to look out for him; but it appears he has not passed through this place. I believe he took the road to Wheeling where he may have taken boat for Lexington. I have written to Messrs. Scott \& Trotter, merchants of my acquaintance in Lexington and have also sent the advertisement for them to have published and have him arrested if found there, observing to add to the advertisement to apply to Messrs. Scott \& Trotter for the reward and costs which will be repaid by me or by you in Philadelphia. Fifty dollars is such a large reward that he cannot possibly escape. Knowledge of his native place might contribute much to his discovery, unless he avoids going among his countrymen. Be assured if he passes through here he will not escape my vigilence."

Nor did he escape. "I have just received your Swiss servant Jacob Heuberger," Mr. Declary wrote October twentieth. "Mr. Alexander Logan arrested him 17 miles from Pittsburg on the banks of the Allegheny where he had been working for two weeks and has just delivered him to me. I put him in jail and as the law allows him only bread and water I decided to send him one meal a day until I hear from you. I paid Mr. A. Logan the reward of $\$ 50$ which you promised in the newspapers. $\mathrm{He}$ is in the jail for criminals. I should have preferred to put 464 
him with the debtors but I could not get them to do so without giving security and without orders from you. He had intended to go to Kentucky; but there happened to be a person of his acquaintance of the name of Miller 30 miles from Pittsburg who has bought 10,000 acres of land. He was on the same boat and that is how they became acquainted. He wishes to be sold back to Mr. Miller in preference to any one else. Mr. Wood, a lawyer of this town wishes to buy him. I am waiting for your answer telling me how you wish him treated in prison and shall act according to your orders."

"Rest assured," was the answer, "that in this instance my conduct has not been dictated by ill-nature or inhumanity, but by the ardent desire to make an example. Consequently I beg you to put the prisoner in the part of the jail reserved for criminals and have him fed on bread and water as the law prescribes, until somebody pays you $\$ 90.52$ cash, the amount of the account herein enclosed, besides the fifty dollars reward and expenses you have paid, making a total of about one hundred and fifty dollars. Do not deviate from this plan. If you can not get that sum he must remain in jail until I am fully reimbursed for all my expenses; otherwise I shall keep him there as long as the law allows. It is therefore useless for him to have any appeals made to me; my resolution is taken in this matter."

Mr. Declary obeyed and reported: "I have taken away the dinner I sent him and he is now on bread and water according to your orders. Mr. Lawyer Wood has called and offered to pay his passage and take him for three years giving as his reason that he will not stay if bound for too long a time. He says for $\$ 150$ he could buy a negro for life. Your servant is in despair in his prison; if he cannot be sold here he will have to be sent back to you."

Vol. I-30 465 
"As to my Swiss servant," was the reply, "I absolutely refuse to deduct anything from the amount I have stated in my letter of the 3 Ist last month (October). This man does not deserve your attention. I beg you not to write to me again on this subject unless it is to tell me that you have sold his time; but as to taking back into my house never even if he would repay me all he has cost me and engage to serve me for nothing. He has run away from my house like a rascal. It is right he should be treated as one. Therefore I wish you to keep him in jail where he is until you are able to dispose of him as I have directed."

Again and again the prisoner appealed to Girard in letters which show him to have been a man of some education. He had been "sorry a hundred thousand times" that he ever "committed the wrong of leaving you." $\mathrm{He}$ would give every assurance possible to give that once out of prison he would pay all. Moreover he had fallen in love with a charming young woman who came to visit a daughter of the keeper of the jail and she was ready to marry him the moment he was free.

Meantime the prisoner began to act for himself. "By means of a petition," wrote Mr. Declary, "which he addressed to the court he was dismissed from prison on the I 8 th of the present month (February, 1804) and returned to me as your agent. If you wish him sent back to you you will have to send some money for the journey and I ask you to fix the sum. If you wish to leave him here he is willing to work for you and pay you a proportionate part of what he is able to earn. It will be impossible to find anybody to buy his time because the debt is too large, and has been increased by the 7 gourdes and 87 cents for the time he was in prison and $\mathrm{I}$ dollar and 74 cents court fees which I paid. The lawyer I was obliged to engage to defend you is not yet paid, and I will ask you to fix the 
sum to be given him. It has been absolutely necessary to get clothing against the coming winter.

"David Davis our inn-keeper is willing to take him at 49 gourdes per month and allow him to keep all his tips. It is the best place for him in this town and he could pay you in less than two years.

"Four months in prison on bread and water is a severe punishment and he could only learn evil there, as he saw no good examples."

"It is not a debt I claim, but the service of my servant, and I want you to obtain justice for me and not waste your principles of humanity on a criminal of whom my duty requires me to make an example," wrote Girard in reply.

"I want you to consult a good lawyer, to whom you will give a proper retainer, and if he thinks you can put my servant in jail until you can send him to me, under escort of one or two constables, I beg you to do it. As soon as you have found one or two trustworthy men give them in charge of the prisoner; after having agreed to pay them for their trouble, as well as their expenses, and those of the prisoner. Make the sum as low as possible and payable in Philadelphia on delivery of the prisoner to my satisfaction. See that the sum does not exceed one hundred gourdes. If after you have confined Jacob Heuberger in jail you can dispose of his time, provided you can get one hundred gourdes cash, and the buyer engages and gives security to pay in a year or eighteen months all our expenses for the arrest, the jail and the lawyers and the like.

"I beg you not to give him any clothing on my account. If you send him back I will see to having him dressed like a gentleman on his arrival here."

While waiting for a chance to carry out the instructions 467 
of Girard the unprofitable servant was hired by Mr. Declary to the livery keeper David Davis, with whom he staid till March IIth, when Mr. Declary wrote: "Your servant Jacob Heuberger escaped on the IIth inst about

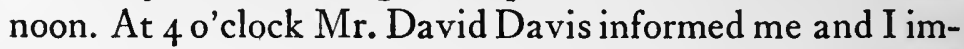
mediately hastened to all the ferries to find out what road he had taken, but could not obtain any information; five boats left the same day. I decided to pursue him the next and search every boat, as I believed he would board one to go to Kentucky. At 7 o'clock in the evening I returned to Mr. Davis to find out if he had come back. During our conversation Mr. Flichman was present and also told us that the man had passed through his ferry 5 miles from Pittsburg on the way to Allegheny between 1 and 2 o'clock and that the man on the other side of the river had recognized him as Mr. Davis's stable boy. The night was dark, so I ordered two horses to pursue him the next day and started after him at an early hour with a good constable, expecting to find him 17 miles from Pittsburg where he was for two weeks before he was captured and where he had an offer to keep a German school. Ten miles out I met a German farmer of my acquaintance on horseback going to the mill. I asked him for information about our man, and he gave me a complete description of him and said he had passed his farm between 3 and 4 o'clock and was going from Baltimore to see his dying mother in Franklin 60 miles from Pittsburg and he put him on the road to Franklin. The road runs to the left at a distance of 12 miles from Pittsburg. Contrary to my expectation I calculated that he probably had a start of 25 miles, and as I did not feel well enough to travel more than a day I decided to send my constable who had a magnificent horse to overtake him. $* * *$ The constable Anderson who knew him pursued him 70 miles and finding he was more 468 


\section{THE CLAIMS ON FRANCE}

than 20 miles distant and on the next day might approach the Canadian border he gave up the persuit. The constable believes that he walked day and night and followed a man with a shawl of his acquaintance going in the same direction. He was seen with a big knife and a bottle of whiskey in his pocket. I remarked that the roads are very soft at this season of the year and that a man on foot can make as good time as a man on horseback. On the 16 th the Constable returned without catching him. If you insist on having him captured he can be taken in Canada by direct correspondence from here. The mail goes as far as Presque Isle and Detroit, where I can find correspondents. $* *$

"The Justice of the Peace, Richardson, and my lawyer, Semple, showed me by an act from the Digest entitled Habeas Corpus Vol. I 55 No. 8 that I could not have him sent back to prison for less than a penalty of 500 pounds."

No further attempt was made to capture the runaway and with this letter all reference to him disappears from the correspondence. Meantime his place seems to have been filled by the purchase of another servant. 



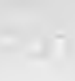






\section{PLEASE DO NOT REMOVE CARDS OR SLIPS FROM THIS POCKET}

\section{UNIVERSITY OF TORONTO LIBRARY}

CT

275

G45N3 v.1

Mcllaster, John Bach

The life and times of Stephen Girard 
